Universidade de São Paulo

Instituto de Psicologia

EINAT HAUZMAN

\title{
ECOLOGIA E EVOLUÇÃo do SISTEMA VISUAL DE SERPENTES CAENOPHIDIA: ESTUdOS COMPARATIVOS DA MORFOLOGIA RETINiana E Genética de OPSINAS
}

SÃO PAULO

2014 


\section{ECOlogia E EVOLUÇÃo do SiSTEMA VISUAL DE SERPENTES CAENOPHIDIA: ESTUdOS COMPARATIVOS DA MORFOLOGIA RETINIANA E GENÉTICA DE OPSINAS}

(versão corrigida)

Tese apresentada ao Instituto de Psicologia da Universidade de São Paulo, como parte das exigências para obtenção do título de Doutora em Ciências.

Orientação: Prof ${ }^{a}$ Dra Dora Fix Ventura Co-Orientação: Prof ${ }^{a}$ Dra Daniela Maria Oliveira Bonci

SÃo PAULO

2014 
AUTORIZO A REPRODUÇÃo E DIVULGAÇÃo TOTAL OU PARCIAL

DESTE TRABALHO, POR QUALQUER MEIO CONVENCIONAL OU

ELETRÔNICO, PARA FINS DE ESTUDO E PESQUISA, DESDE QUE CITADA

A FONTE.

Catalogação na publicação

Biblioteca Dante Moreira Leite

Instituto de Psicologia da Universidade de São Paulo

Hauzman, Einat.

Ecologia e evolução do sistema visual de serpentes Caenophidia: estudos comparativos da morfologia retiniana e genética de opsinas / Einat Hauzman; orientadora Dora Selma Fix Ventura. -- São Paulo, 2014.

$185 \mathrm{f}$.

Tese (Doutorado - Programa de Pós-Graduação em Psicologia. Área de Concentração: Neurociências e Comportamento) - Instituto de Psicologia da Universidade de São Paulo.

1. Retina 2. Serpentes 3. Opsinas 4. Ecologia Visual 5. Fotorreceptores 6. Células Ganglionares 7. Acuidade Visual I. Título. 


\section{FOLHA DE APROVAÇÃO}

Nome: Einat Hauzman

Título: "Ecologia e evolução do sistema visual de serpentes Caenophidia: estudos comparativos da morfologia retiniana e genética de opsinas."

Tese apresentada ao Instituto de Psicologia da Universidade de São Paulo, para obtenção do título de Doutora em Ciências.

Área de Concentração: Neurociências e Comportamento

Tese defendida e aprovada em:

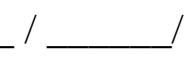

Banca Examinadora

Examinador(a)

Instituição Assinatura

Examinador(a)

Instituição Assinatura

Examinador(a)

Instituição Assinatura

Examinador(a)

Instituição Assinatura

Examinador(a)

Instituição Assinatura 
Ao meu querido Felipe, por todo amor, apoio e incentivo. 


\section{Agradecimentos}

Agradeço à minha orientadora, Professora Dra. Dora Fix Ventura, pelos valiosos ensinamentos, por tornar possível a realização deste trabalho e pelo exemplo de pessoa e pesquisadora.

À minha querida amiga e co-orientadora, Daniela Bonci, pela ajuda constante, por todo apoio, incentivo, por todos os ensinamentos práticos e teóricos, e pelo exemplo de ética, dedicação e amor à ciência.

À FAPESP, pela concessão da bolsa e apoio financeiro.

À Maureen Neitz por todo auxílio e orientação neste projeto, e por me receber tão carinhosamente, juntamente com Jay Neitz em seu laboratório e em sua casa. Agradeço pelos ensinamentos e pelo exemplo de pessoas que são.

À técnica de laboratório Netta Smith, por toda ajuda na parte prática do projeto durante o estágio em Seattle.

Ao Instituto Butantan pelo fornecimento de serpentes, ao Francisco Luis Franco, (Kiko), e aos funcionários e estagiários que me auxiliaram nas procedimentos com os animais: Danusa, Patricia, Valdir, Fernando, Bruno, Dani, Eladio, Reinaldo, Joãozinho, Gileno, Marcelo.

Ao Instituto Israelita de Ensino e Pesquisa (IIEP) do Hospital Israelita Albert Einstein, por aceitar a realização deste projeto e permitir a utilização dos equipamentos. Agradeço à Profa Dra. Anna Carla Goldberg, à Andréa e Martha, à Dra Patricia e Camila, por todo auxílio.

À Professora Dra. Dânia E. Hamassaki, do Laboratório de Biologia Celular da Retina do ICBI, e Sayami e Carol, pelas ajudas e trocas de informações e de materiais.

Ao Felipe Grazziotin, pelas análises filogenéticas no início do projeto.

À Maria José e Elkin, por toda ajuda e ensinamentos das técnicas de filogenia molecular, análises e discussão de resultados.

Ao Vinicius Frayze pelo auxílio com as análises estatísticas.

A todos os amigos e colegas do Labvis, professores, alunos e funcionários, por toda ajuda, pelo agradável convívio e pelo aprendizado diário.

Aos meus pais, à Cris, e todos meus familiares por todo carinho e apoio.

E agradeço especialmente ao meu querido Felipe, por todo incentivo desde o início, pelo apoio, respeito e companheirsimo todos os dias. Muito obrigada! 
"Sua tarefa é descobrir o seu trabalho e, então, com todo o coração, dedicar-se a ele." 


\section{RESUMO}

As estruturas oculares dos vertebrados apresentam diversas adaptações relacionadas aos hábitats e atividades das espécies. A infra-ordem Serpentes possui amplo número de espécies distribuídas em quase todas as regiões da Terra e seu sistema visual apresenta variações que apontam para adaptações ecológicas. O presente estudo teve por objetivo fazer uma análise comparativa do sistema visual de diferentes espécies de serpentes Caenophidia, das famílias Dipsadidae e Colubridae, centrada no potencial de visão de cores, na densidade e topografia celular da retina e na acuidade visual. Para tanto, foram identificados os genes de opsinas expressos nas retinas, e analisadas a densidade e distribuição dos diferentes tipos de fotorreceptores e das células da camada de células ganglionares (CCG). As serpentes obtidas junto ao Laboratório de Herpetologia do Instituto Butantan foram sacrificadas com dose letal do anestésico thiopental. Os olhos foram enucleados e as retinas dissecadas para estudos genéticos e morfológicos, com imunohistoquímica e coloração de Nissl. Para sequenciamento dos genes das opsinas SWS1, Rh1 e LWS, dois olhos de 17 espécies foram utilizados. A amplificação por PCR mostrou que os três genes são expressos nas retinas de todas as espécies analisadas; o pico de sensibilidade espectral $\left(\lambda_{\max }\right)$ de cada opsina foi estimado a partir das sequências de aminoácidos. O $\lambda_{\max }$ do fotopigmento SWS1 foi estimado em $360 \mathrm{~nm}$ (UV), para todas as espécies. O fotopigmento Rh1, apresentou três diferentes combinações de aminoácidos que geram picos de sensibilidade em $500 \mathrm{~nm}, 494 \mathrm{~nm}$ e $484 \mathrm{~nm}$. Todas as espécies de serpentes diurnas apresentaram a combinação de aminoácidos que gerou o $\lambda_{\max } 484 \mathrm{~nm}$. O fotopigmento LWS apresentou 4 diferentes combinações de aminoácidos, com $\lambda_{\max }$ variando entre $543 \mathrm{~nm}$ e $560 \mathrm{~nm}$. Para os estudos morfológicos foram utilizadas 86 retinas de 20 diferentes espécies. Retinas íntegras foram marcadas com anticorpos específicos para quantificação e análise topográfica de fotorreceptores. A coloração de Nissl foi empregada em retinas planas para quantificação de células da CCG e cálculo da acuidade visual. As análises morfológicas em retinas de serpentes noturnas mostraram uma grande densidade média de fotorreceptores $\left(82.042 \pm 37.945\right.$ células $\left./ \mathrm{mm}^{2}\right)$, com predominância de bastonetes, enquanto espécies diurnas apresentaram baixa densidade média de fotorreceptores $\left(11.290 \pm 2.810\right.$ células $\left./ \mathrm{mm}^{2}\right)$ e ausência de bastonetes. Serpentes noturnas apresentaram densidade média mais baixa de células da CCG $(7.653 \pm 1.636$ 
células $\left./ \mathrm{mm}^{2}\right)$ comparada às diurnas $\left(9.575 \pm 2.301\right.$ células $\left./ \mathrm{mm}^{2}\right)$. O poder de resolução espacial também foi maior em espécies diurnas $(2,3 \pm 0,7 \mathrm{cpg})$ do que nas noturnas $(1,45 \pm 0,4 \mathrm{cpg})$. A distribuição de fotorreceptores e células da CCG nas retinas mostrou a presença de area centralis em diferentes regiões das retinas de espécies noturnas, e faixa horizontal em retinas das espécies diurnas, com exceção da serpente aquática e diurna Helicops modestus, que apresentou area centralis. As diferenças de localização das areae centralis variaram de acordo com hábitat e características comportamentais das espécies. Serpentes fossoriais do gênero Atractus, por exemplo, apresentaram area centralis na região dorsal da retina, que favorece o campo de visão inferior e auxilia no comportamento de escavar. Os resultados obtidos neste abrangente estudo apontam para a complexidade das adaptações do sistema visual deste grupo de vertebrados. As variações do padrão de atividade (diurna ou noturna) e uso de hábitat parecem ser fatores de forte influência sobre as características do sistema visual, como a sensibilidade espectral dos pigmentos visuais, a densidade e distribuição de neurônios nas retinas e o poder de resolução espacial do olho.

Palavras-chave: Serpentes, Retina, Opsinas, Ecologia Visual, Fotorreceptores, Células Ganglionares, Acuidade Visual. 


\section{ABSTRACT}

The structures of vertebrate eyes have many adaptations related to the habitats and activities of the species. The infra-order Serpentes has a large number of species distributed in almost all regions of the Earth and its visual system presents variations that point to ecological adaptations. This study aimed to compare the visual system of different species of Caenophidian snakes, from the Dipsadidae and Colubridae families. To do so, the opsin genes expressed in the retinas were identified and the density and distribution of the different types of photoreceptors and the cells of the ganglion cell layer (GCC) were analyzed. The snakes were colected from Butantan Institute and were sacrificed with a lethal dose of the anesthetic thiopental. The eyes were enucleated and the retinas dissected for genetic and morphological studies, using Nissl stainig technique and immunohistochemistry. For the sequencing the opsins genes SWS1, Rh1 and LWS, two eyes of 17 species were colected. PCR amplification showed that the three opsin genes are expressed in the retinas of all species analyzed; the maximum spectral sensitivity $\left(\lambda_{\max }\right)$ of each opsin was estimated based on the amino acid sequences. The $\lambda_{\max }$ of the SWS1 photopigment was estimated at $360 \mathrm{~nm}$ (UV), for all species. The photopigment Rh1 had three different combinations of amino acids that generate $\lambda_{\max }$ at $500 \mathrm{~nm}, 494 \mathrm{~nm}$ and $484 \mathrm{~nm}$. All diurnal species had the amino acid combination that generate the $\lambda_{\max }$ at $484 \mathrm{~nm}$. The photopigment LWS had 4 different combinations of amino acids with $\lambda_{\max }$ ranging from $543 \mathrm{~nm}$ to $560 \mathrm{~nm}$. For morphological studies, 86 retinas of 20 different species were analyzed. Wholemounted retinas were stained with specific antibodies for analysis of the photoreceptors density and topography. The Nissl stainig technique was used for quantification of GCL cells in flatmounted retinas and estimation of the spatial resolving power. Nocturnal snakes had retinas with higher photoreceptor densities $\left(82,042 \pm 37,945\right.$ cells $\left./ \mathrm{mm}^{2}\right)$, with predominance of rods, compared to diurnal species that had low photoreceptors density $(11,290 \pm 2,810$ cells $/ \mathrm{mm}^{2}$ ) and the absence of rods. On the other hand, diurnal snakes had higher density of GCL cells $\left(9,575 \pm 2,301\right.$ cells $\left./ \mathrm{mm}^{2}\right)$ and spatial resolving power $(2.3 \pm 0.7$ cpd), compared to nocturnal $\left(7,653 \pm 1,636 \mathrm{cells} / \mathrm{mm}^{2}\right.$ and $\left.1.45 \pm 0.4 \mathrm{cpg}\right)$. The distribution of cells in the retinas had variations related to the circadian rhythm of the species, with the presence of area centralis in retinas of nocturnal species and horizontal streak in retinas of diurnal snakes, except for the diurnal and aquatic Helicops 
modestus, that had an area centralis in the ventral retina. The location of the area centralis varies according the habitat and specific behavior of each species. The fossorial snake Atractus, for example, had an area in the dorsal retina, which improves the resolution of the inferior visual field and benefits the digging habit in this snake. The results of this comprehensive study point to the complexity of adaptations of the visual system of this group of vertebrates. The differences in the activity pattern (diurnal or nocturnal) and habitat seem to be of great influence on the characteristics of the visual system, such as the spectral sensitivity of the visual pigments, the density and distribution of neurons in the retina and the spatial resolving power of eye.

Keywords: Snakes, Retinas, Photoreceptors, Opsins, Visual Ecology, Ganglion Cells, Visual Acuity. 


\section{Lista de Figuras}

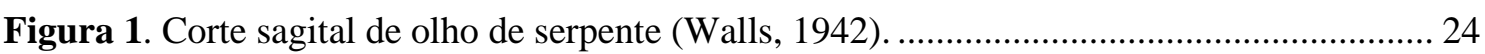

Figura 2. Estrutura da retina de mamíferos (Ramon y Cajal, 1990) ............................................ 24

Figura 3. Corte histológico de retina da serpente Philodryas olfersii, com as dez camadas características da retina dos vertebrados. Coloração: Hematoxilina-Eosina. CEP, camada do epitélio pigmentar; CF, camada de fotorreceptores; MLE, membrana limitante externa; CNE, camada nuclear externa; CPE, camada plexiforme externa; CNI, camada nuclear interna; CPI, camada plexiforme interna; CCG, camada de células ganglionares; CFN, camada de fibras nervosas; MLI, membrana limitante interna (Hauzman et al, 2014) .... 25

Figura 4. Representação de corte transversal de fotorreceptores da retina de vertebrados (modificado de Burns \& Lamb, 2003).

Figura 5. Diagrama esquemático do segmento externo de um bastonete e a opsina inserida na membrana plasmática (modificado de: http://webvision.med.utah.edu/photo1.html\#outer

28

Figura 6. Diagrama da estrutura do pigmento visual de vertebrados. (A) O passo inicial da fototransdução consiste na absorção de um fóton pelo 11-cis retinal, que se converte para a forma all-trans retinal. (B) visão lateral de um fotopigmento mostrando a presença de sete domínios transmembrânicos, típicos da superfamília de receptores acoplados a proteína $\mathrm{G}$ e $(\mathrm{C})$ seção da membrana, mostrando o seu arranjo ao redor do cromóforo retinal (laranja). TM, transmembrana; CL, loop citoplasmático; EC, loop extra celular. A numeração é baseada na sequência da rodopsina bovina (RH1) (modificado de Davies et al., 2012).

Figura 7. Estrutura triminensional da rodopsina bovina. Os sete domínios transmembrânicos estão ilustrados em diferentes cores. O cromóforo está identificado em vermelho (Palczewski et al., 2000)

Figura 8. Pico de sensibilidade espectral dos três tipos de cones presentes na retina de humanos (modificado de Deeb \& Motulsky, 2005)

Figura 9. Relação filogenética entre os principais grupos de opsinas de vertebrados. Quatro eventos de duplicação originaram os genes LWS, SWS1, SWS2 e depois os genes RH1 e RH2 (modificado de Bailes et al., 2007)

Figura 10. Reconstrução da história evolutiva dos genes de opsinas de vertebrados. Quatro genes de opsinas estão presentes no vertebrado sem mandíbula ancestral: LWS, SWS1, SWS2 e Rh. Após a especiação dos vertebrados com mandíbulas, a opsina ancestral Rh sofreu uma duplicação levando a formação dos genes Rh1 e Rh2 no ancestral dos vertebrados mandibulados. Independentemente, o gene Rh sofreu uma duplicação na linhagem de vertebrados sem mandibulas, gerando os genes RhA e RhB. A perda dos genes de opsinas SWS2 e Rh2 no mamífero ancestral é mostrada, bem como o recente evento de duplicação da opsina LWS de mamíferos, que originou as opsinas LWS e MWS (modificado de Tresize \& Collin, 2005)

Figura 11. Estrutura secundária da rodopsina RH1 bovina, mostrando mutações de aminoácidos que ocorrem naturalmente e causam deslocamento significativo do $\lambda_{\max }$. O modelo é baseado em Palczewski et al. (2000). Círculos azuis, vermelhos e pretos indicam os sítios envolvidos no deslocamento dos pigmentos SWS1, LWS/MWS e RH1/RH2, respectivameto. O 11-cis-retinal está mostrado em laranja (Yokoyama, 2002)

Figura 12. A. Mapa topográfico de fotorreceptores de retina de tartagura de água doce Trachemis scripta elegans, com faixa horizontal se estendendo ao longo do eixo nasaltemporal. O ponto branco representa o nervo óptico (Gotzner, 2005). B. Mapa 
topográfico de células da CCG em retina de cutia, Dasyprocta aguti, com faixa horizontal bem definida. Densidade $\times 10^{3}$ celulas $/ \mathrm{mm}^{2}$. O ponto escuro representa o nervo óptico (Silveira et al., 1989). N: nasal; V: ventral

Figura 13. A. Mapa topográfico de células da CCG da retina de preguiça Choloepus didactylus, com faixa visual verticalmente orientada na região temporal. Densidade $\times 10^{3}$ celulas por $\mathrm{mm}^{2}$ (Andrade-Da-Costa et al., 1989). B. Mapa topográfico de células da CCG de retina de elefante africano, Loxodonta africana, com faixa visual verticalmente orientada na região temporal (Stone \& Halasz, 1989). T: temporal; V: ventral

Figura 14. A. Mapa topográfico de células da CCG de retina de Myiozetes cayenensis (Aves), com area centralis na região central e fóvea temporal. Densidade $\times 10^{3}$ células por $\mathrm{mm}^{2}$ (Coimbra et al., 2006). B. Mapa topográfico de células da CCG de retina de Halcyon sancta (Aves), com area centralis na região central, fóvea nasal (monocular) e fóvea temporal (binocular). Densidade $\times 10^{3}$ células por $\mathrm{mm}^{2}$ (Moroney \& Pettigrew, 1987). T: temporal; V: ventral

Figura 15. A. Fóvea convexiclivate de ave Pitangus sulphuratus (Coimbra et al., 2006). B. Fóvea concaviclivate (*) de primata Macaca mulata (Collin 2008). 43

Figura 16. Relação filogenética entre serpentes, lagartos e anfisbenídeos, inferida a partir de sequências de DNA dos genes RAG1 e C-mos. Para os nós mais críticos, valores de quatro métodos de construção filogenética são mostrados na seguinte ordem: valores de suporte de bootstrap de máxima verossimilhança (MV), máxima parcimônia (MP), evolução mínima e probabilidade posterior Bayesiana. Para os outros nós são mostrados os valores de suporte de bootstrap de MP seguido das probabilidades posteriores Bayesianas (Vidal \& Hedges, 2004).

Figura 17. Cladograma esquemático mostrando a relação filogenética entre serpentes Scolecophidia (cobras cegas), Henophidia (pítons e boas) e Caenophidia (colubrídeos, dipsadideos, víboras) (modificado de Davies et al., 2009) 47

Figura 18. Anatomia funcional de olho de lagarto (A e C) e de serpente (B e D), ilustrando as principais diferenças entre os dois tipos. $\mathrm{C}$, lagarto foca a imagem na retina contraindo os grandes músculos ciliares (bm, cm) ancorados aos ossículos da esclera (so), aplicando assim uma pressão na superfície lateral do cristalino (ln). D, serpentes focam a imagem na retina movendo o cristalino para frente, pelo aumento da pressão no vítreo (vi), devido à contração de músculos periféricos da íris (im). Abreviações: an, via anterior; bm, músculo ciliar de Brücke; cb, corpo ciliar; ch, coróide; cm, músculo ciliar de Crompton; cn, cônus papilar; co, córnea; el, pálpebra; fv, fóvea; id, músculo dilatador da íris; is, músculo do esfincter da íris; ln, lente; re, retina; sc, cartilagem da esclera; sl, esclera; sp, espectáculo; vi, humo vítreo; zf, fibras zonulares (Caprette et al., 2004) .......................... 50

Figura 19. Representação morfológica de fotorreceptores de serpentes: (A) cones duplos, (B) cones simples grandes, (C) cones simples pequenos, (D) cones simples com mióide grande, (E) cones simples pequenos com mióide extremamente longo, (F) cone duplo com mióide extremamente longo, $(\mathrm{G})$ bastonete longo e $(\mathrm{H})$ bastonete curto. Abreviações: se, segmento externo; el, elipsóide; ml, membrana limitante; nu, núcleo; ts, terminal sináptico; mi, mióide. A seta representa a direção da luz pela retina (modificado de Caprette, 2005)

Figura 20. Representação de corte transversal de fotorreceptores da tartaruga Trachemys scripta. (A) cone simples, (B) cone duplo, (C) bastonete. Abreviações: se, segmento externo; go, gotícula de óleo; el, elipsóide; pa, parabolóide; ml, membrana limitante; mi, mióide; nu, núcleo; ts, terminal sináptico. A seta indica a direção da passagem da luz pela retina (Caprette, 2005) 
Figura 21. Cladograma sumário mostrando a progressão evolutiva de cada classe de opsina, mediada pela conservação genética, perda e duplicação, dentro dos principais ramos da radiação dos craniatas. No grupo das serpentes os pigmentos SWS2 e Rh2 foram perdidos. Datas aproximadas de especiação estão mostradas em milhões de anos (modificado de Davies et al., 2012) 55

Figura 22. Mapas topográficos de fotorreceptores da serpente arborícola Philodryas olfersii, com faixa horizontal, e da serpente terrícola $P$. patagoniensis, com area centralis no quadrante ventro-rostral da retina. $\mathrm{D}$, dorsal; $\mathrm{T}$, temporal. $\mathrm{O}$ ponto braço representa a saída do nervo óptico. Barras de escala 2 mm (Hauzman et al., 2014)............................ 58

Figura 23. Corte transversal de olho da serpente noturna Sibynomorphus neuwiedi (A) e da diurna Tomodon dorsatus (B). A distância posterior nodal (PND), do centro do cristalino até a borda de retina-coróide, está representada pela linha tracejada em vermelho e corresponde a cerca de 52\% do diâmetro axial do olho. Barra de escala $1 \mathrm{~mm}$................ 78

Figura 24. Análise filogenética das sequências de nucleotídeos das cinco classes de opsinas de vertebrados, construída pelo método de Máxima Verossimilhança (MV). A topologia da $\mathrm{AB}$ recuperou uma topologia consenso similar à melhor árvore de MV. Grupo das serpentes destacado em vermelho. As espécies de hábitos noturnos do grupo Caenophidia estão representadas em azul. A opsina ciliar do anelídeo Platynereis dumerilii (GenBank: AY692353), foi utilizado como grupo externo (dado não mostrado). Os valores apresentados correspondem à probabilidade posterior $(\mathrm{PP})$ na $\mathrm{AB}$ e os valores de suporte obtidos por bootstrap na análise de MV, obedecendo a ordem AB/MV. A barra de escala representa o número de substituições de nucleotídeos por sítio 81

Figura 25. Análise filogenética das sequências de nucleotídeos das opsinas LWS de serpentes e lagartos, recuperada pelo método de Máxima Verossimilhança (MV). A topologia da AB recuperou uma topologia consenso similar à melhor árvore de MV. Grupo das serpentes destacado pelas linhas vermelhas. As espécies de hábitos noturnos do grupo Caenophidia estão representadas em azul. Os símbolos ao lado de cada espécie diferenciam as serpentes da família Colubridae $(\diamond)$, e das duas subfamílias da família Dipsadidae: Dipsadinae (•) e Xenodontinae (ロ), conforme classificação de Zaher et al., 2009. As barras da direita distinguem os grupos Caenophidea (C), Henophidea (H) e lagartos (L). Os valores apresentados nos nós correspondem às probabilidades bayesianas e aos suportes de bootstrap, respectivamente. A barra de escala representa o número de substituições de nucleotídeos por sítio 82

Figura 26. Análise filogenética das sequências de nucleotídeos das opsinas SWS1 de serpentes e lagartos, recuperada pelo método de Máxima Verossimilhança (MV). A topologia da $\mathrm{AB}$ recuperou uma topologia consenso similar à melhor árvore de MV. Grupo das serpentes destacado pelas linhas vermelhas. As espécies de hábitos noturnos do grupo Caenophidia estão representadas em azul. Os símbolos ao lado de cada espécie diferenciam as serpentes da família Colubridae $(\diamond)$, e das duas subfamílias da família Dipsadidae: Dipsadinae (•) e Xenodontinae (ロ), conforme classificação de Zaher et al., 2009. As barras da direita diferenciam os grupos Caenophidea (C), Henophidea (H) e lagartos $(\mathrm{L})$. Os valores apresentados nos nós correspondem às probabilidades bayesianas e aos suportes de bootstrap, respectivamente. A barra de escala representa o número de substituições de nucleotídeos por sítio

Figura 27. Análise filogenética das sequências de nucleotídeos das opsinas Rh1 de serpentes e lagartos, recuperada por MV. A topologia da $\mathrm{AB}$ recuperou uma topologia consenso similar de MV. Grupo das serpentes destacado pelas linhas vermelhas. As serpentes Caenophidia noturnas estão representadas em azul. Os símbolos ao lado de cada espécie 
diferenciam as serpentes da família Colubridae $(\diamond)$, e das duas subfamílias da família Dipsadidae: Dipsadinae ( ) e Xenodontinae (־) (Zaher et al., 2009). As barras da direita diferenciam os grupos Caenophidea (C), Henophidea $(\mathrm{H})$ e lagartos (L). Os valores apresentados nos nós correspondem às probabilidades bayesianas e aos suportes de bootstrap, respectivamente. A barra de escala representa o número de substituições de nucleotídeos por sítio 84

Figura 28. Curvas de sensibilidade espectral previstas a partir das sequências de aminoácidos do pigmento Rh1 de diferentes espécies de serpentes. A curva de $500 \mathrm{~nm}$ corresponde ao perfil DEMHWAA, a curva de $494 \mathrm{~nm}$ ao perfil NEMWHAA e a curva de $484 \mathrm{~nm}$ corresponde ao perfil NEMWHSA 86

Figura 29. Curva de sensibilidade espectral prevista a partir das sequências de aminoácidos do pigmento SWS1 de serpentes, com pico em $360 \mathrm{~nm}$ para todas as espécies 87

Figura 30. Curvas de sensibilidade espectral previstas a partir das sequências de aminoácidos do pigmento LWS de cones de diferentes espécies de serpentes. A curva de $560 \mathrm{~nm}$ corresponde ao perfil SHYTA, a de $553 \mathrm{~nm}$ ao perfil AHYTA e a de $537 \mathrm{~nm}$ corresponde ao perfil AHYAA, e a curva de 543 corresponde a combinação AHFTA 88

Figura 31. . Sensibilidade espectral estimada a partir da sequência de aminoácidos dos pigmentos visuais Rh1 ( ), LWS $(\boldsymbol{\Delta})$ e SWS1 $(\bullet)$ de serpentes noturnas (fundo azul) e diurnas (fundo amarelo). Em serpentes diurnas o pigmento Rh1 teve um deslocamento para o azul, enquanto o pigmento LWS apresentou maior deslocamento para o vermelho na maioria das espécies, reduzindo desta forma o grau de sobreposição dos picos de sensibilidade espectral dos dois pigmentos

Figura 32. Variações da sensibilidade espectral de serpentes Caenophidia, estimadas a partir das sequências de aminoácidos das opsinas Rh1, LWS e SWS1. Rh1 com três possíveis combinações (NEMHWSA, NEMHWAA e DEMHWAA); LWS com quatro possíveis combinações (AHYAA, AHFTA, AHYTA e SHYTA). O fotopigmento SWS1 de todas as espécies apresentou $\lambda_{\max }$ de $360 \mathrm{~nm}$. Em serpentes diurnas (fundo amarelo) o gene Rh1 é expresso em cones e deve contribuir para a visão de cores diurna. Em serpentes noturnas (fundo azul), o gene Rh1 é expresso em bastonetes (representados pela linha tracejada nos gráficos). 9 espécies*: C. bicarinatus, E. cephalostriata, E. undulata, E. aesculapii, E. miliaris, H. modestus, P. patagoniensis, S. pullatus e T. persimilis.

Figura 33. Cortes radiais de retinas da serpente diurna E. miliaris (A) e noturna D. petersi (B) revelados com o marcador para fluorescência DAPI. CF, camada dos fotorreceptores; CNE, camada nuclear externa; CPE, camada plexiforme externa; CNI, camada nuclear interna; CPI, camada plexiforme interna; CCG, camada de células ganglionares. Barras da escala $40 \mu \mathrm{m}$.

Figura 34. Corte radial de retina da serpente noturna $D$. petersi, marcada com PNA (A) e com WGA (B). A seta na figura A aponta para a marcação do segmento externo de cones. Na figura $\mathrm{B}$, a seta aponta para a região dos segmentos externos dos bastonetes marcados pelo WGA. CF, camada de fotorreceptores; CNE, camada nuclear externa. Barras da escala $40 \mu \mathrm{m}$

Figura 35. Cortes radiais de retinas marcadas com os anticorpos JH492 anti-opsinas de cone L/M e JH455, anti-opsinas de cone S. Acima, retinas de serpente noturna $D$. petersi marcada com JH492 (A), revelando os segmentos externos de grande quantidade de cones, e marcada com JH455 (B), revelando os segmentos externos de pequeno número de cones. Abaixo, retina da serpente diurna $H$. modestus, com grande quantidade de cones simples e duplos marcados pelo JH492 (C) e pequena quantidade de cones simples marcados pelo JH455 (D). As setas em todas as imagens apontam para os segmentos 
externos dos fotorreceptores imunomarcados. CF, camada dos fotorreceptores; CNE, camada nuclear externa; CPE, camada plexiforme externa; CNI, camada nuclear interna; CPI, camada plexiforme interna; CCG, camada de células ganglionares. Barras de escala $40 \mu \mathrm{m}$

Figura 36. Imagem de campo amostrado de retina de Echinantera undulata, corada pela técnica de Nissl, com foco na camada de células ganglionares (CCG); n, neurônios; g, células da glia. Barra de escala $20 \mu \mathrm{m}$ 95

Figura 37. Variações da densidade média e do número total de células da CCG (A, B), das áreas das retinas $(\mathrm{C})$ e dos valores estimados do poder de resolução espacial (D), das retinas de serpentes noturnas (em azul) e diurnas (em amarelo): Apan, Atractus pantostictus; Aret, A. reticulatus; Dalb, Dipsas albifrons; Dpet, D. petersi; Ogui, Oxyrhopus guibei; Smik, Sibynomorphus mikanii; Snew, S. neuwiedi; Hmo, Helicops modestus; Cbic, Chironius bicarinatus; Eund, Echinantera undulata; Eaes, Erythrolamprus aesculapii; Emil, E. miliaris; Epoe, E. poecilogyrus; Spul, Spilotes pullatus; Tstri, Thamnodynates strigatus; Tdor, Tomodon dorsatus.

Figura 38. Campos amostrados de retinas aplanadas sobre lâmina, com foco na região do segmento interno de fotorreceptores, imunomarcados de forma inespecífica pelos diferentes anticorpos primários utilizados (A e B). A, retina de serpente noturna $D$. petersi, com alta densidade de fotorreceptores. B, retina da serpente diurna $C$. bicarinatus, com fotorreceptores maiores e em menor número. Barras de escala 20 $\mu \mathrm{m}$. 99

Figura 39. Imagens de um mesmo campo amostrado de retina da serpente noturna Dipsas bucephala, imunomarcada com anticorpo anti-opsinas L/M. Com o ajuste do foco do microscópio é possível visualizar os segmentos internos de bastonetes (A) ou de cones (B). Em C, os segmentos externos de cones L/M, marcados pelo anticorpo JH492, e revelados pela molécula fluorescente TRITC. Barras de escala $20 \mu \mathrm{m}$ 100

Figura 40. Imagens de retinas marcadas com o o anticorpo JH455, anti cones-S. Nas retinas de serpentes diurnas $(\mathrm{A}, \mathrm{C})$ e noturnas $(\mathrm{B}, \mathrm{D})$ são evidenciados os segmentos externos de cones UV. A, E. aesculapii; B. D. bucephala; C, S. pullatus; D, S. mikanii. Barras de escala $20 \mu \mathrm{m}$ 103

Figura 41. Imagens de retinas marcadas com o anticorpo JH492, anti cones-LM. Nas retinas de serpentes diurnas $(\mathrm{A}, \mathrm{C}, \mathrm{E})$ e noturnas $(\mathrm{B}, \mathrm{D}, \mathrm{F})$ são evidenciados os segmentos externos de cones L. A, C. bicarinatus; B. O. guibei; C, H. modestus; D, D. bucephala; E, T. dorsatus; F, S. mikanii. Barras de escala $20 \mu \mathrm{m}$ 104

Figura 42. Variações da densidade média (células $/ \mathrm{mm}^{2}$ ) e do número total da população de fotorreceptores $(\mathrm{A}, \mathrm{B})$, da população total de cones $(\mathrm{C}, \mathrm{D})$, da população de cones L/M (E, F) e da população de cones UV (G, H), de retinas de serpentes noturnas (em azul) e diurnas (em amarelo): Apan, Atractus pantostictus; Aret, A. reticulatus; Dbuc, Dipsas bucephala; Ogui, Oxyrhopus guibei; Smik, Sibynomorphus mikanii; Snew, S. neuwiedii; Hmo, Helicops modestus; Cbic, Chironius bicarinatus; Eund, Echinantera undulata; Eaes, Erythrolamprus aesculapii; Emil, E. miliaris; Epoe, E. poecilogyrus; Spul, Spilotes pullatus; Thyp, Thamnodynastes hypoconia; Tnat, T. natererii; Tstri, T. strigatus; Tdor, Tomodon dorsatus. 108

Figura 43. Densidade média (células $/ \mathrm{mm}^{2}$ ) de fotorreceptores de serpentes diurnas. Hmo, Helicops modestus; Cbic, Chironius bicarinatus; Eund, Echinantera undulata; Eaes, Erythrolamprus aesculapii; Emil, E. miliaris; Epoe, E. poecilogyrus; Spul, Spilotes pullatus; Thyp, Thamnodynastes hypoconia; Tstri, T. strigatus; Tdor, Tomodon dorsatus 
Figura 44. Densidade média de cones UV (células $/ \mathrm{mm}^{2}$ ), com distinção entre o sexo: fêmeas marcadas em vermelho e machos em cinza. Apan, Atractus pantostictus; Aret, A. reticulatus; Dbuc, Dipsas bucephala; Ogui, Oxyrhopus guibei; Smik, Sibynomorphus mikanii; Hmo, Helicops modestus; Cbic, Chironius bicarinatus; Eaes, Erythrolamprus aesculapii; Emil, E. miliaris; Epoe, E. poecilogyrus; Spul, Spilotes pullatus; Tstri, Thamnodynastes strigatus; Tdor, Tomodon dorsatus

Figura 45. Gráfico da densidade média de fotorreceptores e de células da CCG, em retinas de serpentes noturnas (azul) e diurnas (amarelo): Apan, A. pantostictus; Aret, A. reticulatus; Dalb, D. albifrons; Dbuc, D. bucephala; Dpet, D. petersi; Oguib, O. guibei; Smik, S. mikanii; Sneu, S. neuwiedi; Hmod, H. modestus; Cbic, C. bicarinatus; Eund, E. undulata; Eaes, E. aesculapii; Emil, E. miliaris; E poe, E. poecilogyrus; Spul, S. pullatus; Thyp, T. hypoconia; Tnat, T. natererii; Tstri, T. strigatus; Tdor, T. dorsatus. 111

Figura 46. Mapas de isodensidade de neurônios de retinas de A. reticulatus. Os mapas apresentam distribuição do tipo area centralis anisotrópica, todas localizadas na região dorsal da retina. As barras de gradiente de cinza ao lado de cada mapa representam o número de células por $\mathrm{mm}^{2}$. A saída do nervo óptico está representada pelo ponto branco. $\mathrm{D}$, dorsal; T, temporal. 115

Figura 47. Mapas de isodensidade de neurônios de retinas de $C$. bicarinatus. Distribuição em faixa visual, com exceção da area centralis dos cones UV. As barras de gradiente de cinza ao lado de cada mapa representam o número de células por $\mathrm{mm}^{2}$. A saída do nervo óptico está representada pelo ponto branco. $\mathrm{D}$, dorsal; $\mathrm{T}$, temporal 116

Figura 48. Mapas de isodensidade de neurônios de retinas de D. bucephala. Distribuição de células do tipo area centralis anisotrópica na região ventral ou central da retina. As barras de gradiente de cinza ao lado de cada mapa representam o número de células por $\mathrm{mm}^{2}$. A saída do nervo óptico está representada pelo ponto branco. D, dorsal; T, temporal ....... 117

Figura 49. Mapas de isodensidade de neurônios células da CCG e fotorreceptores de retina de E. undulata, com distribuição em faixa visual. As barras de gradiente de cinza ao lado dos mapas representam o número de células por $\mathrm{mm}^{2}$. A saída do nervo óptico está representada pelo ponto branco. $\mathrm{D}$, dorsal; $\mathrm{T}$, temporal. 118

Figura 50. Mapas de isodensidade de neurônios de retinas de E.aesculapii, com faixa visual, para células da CCG, fotorreceptores e cones L/M. A população de cones UV apresentou distribuição do tipo area centralis na região central da retina. As barras de gradiente de cinza ao lado de cada mapa representam o número de células por $\mathrm{mm}^{2}$. A saída do nervo óptico está representada pelo ponto branco. $\mathrm{D}$, dorsal; $\mathrm{T}$, temporal

Figura 51. Mapas de isodensidade de neurônios de retinas de E. miliaris, com faixa visual, para células da CCG e fotorreceptores, e uma faixa pouco definida para cones L/M. A população de cones UV apresentou distribuição do tipo area centralis na região ventral da retina. As barras de gradiente de cinza ao lado de cada mapa representam o número de células por $\mathrm{mm}^{2}$. A saída do nervo óptico está representada pelo ponto branco. $\mathrm{D}$, dorsal; $\mathrm{T}$, temporal 120

Figura 52. Mapas de isodensidade de neurônios de retinas de E. poecilogyrus, com faixa visual, para células da CCG e fotorreceptores, e area centralis de cones UV na região central. As barras de gradiente de cinza representam o número de células por $\mathrm{mm}^{2}$. A saída do nervo óptico está representada pelo ponto branco. $\mathrm{D}$, dorsal; $\mathrm{T}$, temporal . 121

Figura 53. Mapas de isodensidade de neurônios de retinas de $H$. modestus, com area centralis na região central da retina para CCG e na região ventro-temporal da retina para os fotorreceptores. A distribuição de cones $\mathrm{L} / \mathrm{M}$ apresentou uma faixa vertical na região nasal da retina. A distribuição de cones UV mostrou uma area centralis anisotrópica na 
região ventral. As barras de gradiente de cinza ao lado de cada mapa representam o número de células por $\mathrm{mm}^{2}$. A saída do nervo óptico está representada pelo ponto branco. $\mathrm{D}$, dorsal; T, temporal

Figura 54. Mapas de isodensidade de neurônios de retinas de $O$. guibei, com uma distribuição difusa, sem formação de área ou faixa definidas para as células da CCG e para cones L/M. A distribuição de fotorreceptores apresentou uma area centralis na região central da retina, assim como a distribuição de cones UV, que apresentou uma área deslocada para a região nasal. As barras de gradiente de cinza representam o número de células por $\mathrm{mm}^{2}$. A saída do nervo óptico está representada pelo ponto branco. D, dorsal; T, temporal ... 123

Figura 55. Mapas de isodensidade de neurônios de retinas de S. mikanii. O mapa de células da CCG apresentou uma distribuição relativamente difusa com área pouco definida na região ventral. Os mapas de fotorreceptores, juntamente com os mapas de cones, de bastonetes e de cones L/M, mostraram a formação de area centralis na região temporal da retina. Os cones UV apresentaram area centralis pouco definida na região ventral. As barras de gradiente de cinza ao lado de cada mapa representam o número de células por $\mathrm{mm}^{2}$. Saída do nervo óptico representada pelo ponto branco. $\mathrm{D}$, dorsal; $\mathrm{T}$, temporal 124

Figura 56. Mapas de isodensidade de neurônios de retinas de $S$. neuwiedi. O mapa de células da CCG apresentou uma distribuição relativamente difusa sem formação de uma área delimitada e maior densidade de células na região dorsal da retina. O mapa de fotorreceptores apresentou uma area centralis na região central da retina. As barras de gradiente de cinza representam o número de células por $\mathrm{mm}^{2}$. Saída do nervo óptico representada pelo ponto branco. $\mathrm{D}$, dorsal; $\mathrm{T}$, temporal

Figura 57. Mapas de isodensidade de neurônios de retinas de $S$. pullatus, com faixa visual pouco definida tanto para células da CCG como para fotorreceptores. Cones UV formaram uma area centralis na região ventral da retina. As barras de gradiente de cinza representam o número de células por $\mathrm{mm}^{2}$. A saída do nervo óptico está representada pelo ponto branco. D, dorsal; $\mathrm{T}$, temporal 126

Figura 58. Mapas de isodensidade de neurônios de retinas de T. strigatus. Células da CCG apresentaram area centralis na região nasal da retina, enquanto fotorreceptores formaram uma faixa visual pouco definida. A população de cones L/M se mostrou relativamente difusa com uma leve tendência à formação de faixa visual, acompanhando a distribuição de fotorreceptores. A população de cones UV apresentou distribuição do tipo area centralis localizada na região central. As barras de gradiente de cinza ao lado de cada mapa representam o número de células por $\mathrm{mm}^{2}$. A saída do nervo óptico está representada pelo ponto branco. D, dorsal; T, temporal ................................................ 127

Figura 59. Mapas de isodensidade de neurônios de retinas de $T$. dorsatus, com distribuição do tipo faixa visual para células da CCG, fotorreceptores e cones L/M. Cones UV apresentaram distribuição do tipo area centralis com maior densidade na região ventral da retina. As barras de gradiente de cinza representam o número de células por $\mathrm{mm}^{2}$. A saída do nervo óptico está representada pelo ponto branco. D, dorsal; T, temporal....... 128

Figura 60. Espectro de absorção dos pigmentos visuais Rh1 (A), SWS1 (B) e LWS (C) de $X$. unicolor, regenerado in vitro com 11-cis-retinal (modificado de Davies et al., 2009) ... 133

Figura 61. Análise filogenética das sequências de nucleotídeos do pigmento visual Rh1 de serpentes e lagartos, construída pelo método de Máxima Verossimilhança. Os valores apresentados correspondem às probabilidades bayesianas e aos suportes de bootstrap. Grupo das serpentes destacado em vermelho; espécies de hábitos noturnos representadas em azul. As sequências de aminoácidos relevantes para o deslocamento espectral do fotopigmento Rh1 estão descritas para cada espécie, com as mutações D83N e A292S em 
destaque (verde), e ao lado entre parênteses os valores do pico de sensibilidade espectral estimados a partir da sequência de aminoácidos. C, Caenophidia; H, Henophidia; L, lagartos. A barra de escala representa o número de substituições de nucleotídeos por sítio 136

Figura 62. Análise filogenética das sequências de nucleotídeos do pigmento visual LWS de serpentes e lagartos (grupo externo), construída pelo método de Máxima Verossimilhança. Os valores apresentados correspondem às probabilidades bayesianas e aos suportes de bootstrap. Grupo das serpentes destacado em vermelho; espécies de hábitos noturnos representadas em azul. As sequências de aminoácidos relevantes para o deslocamento espectral fotopigmento LWS estão descritas para cada espécie, com as mutações S180A, Y277F e T285A em destaque (vermelho), e ao lado entre parênteses os valores do pico de sensibilidade espectral estimados a partir da sequência de aminoácidos. C, Caenophidia; H, Henophidia; L, lagartos. A barra de escala representa o número de substituições de nucleotídeos por sítio 140 


\section{Lista de Tabelas}

Tabela 1. Espécies de serpentes utilizadas nos estudos comparativos do sistema visual (genética de opsinas e morfologia da retina)

Tabela 2. Espécies de serpentes e número de indivíduos obtidos para estudos de morfologia da retina e genética de opsinas 64

Tabela 3. Descrição dos primers squamata-específicos utilizados para amplificar genes de opsinas expressos em retinas de serpentes 66

Tabela 4. Descrição dos primers utilizados para amplificar os três genes de opsinas expressos em retinas de serpentes Caenophidia

Tabela 5. Análises estereológicas da populção de células da CCG e parâmetros anatômicos utilizados para estimar o poder de resolução espacial 96

Tabela 6. Análises estereológicas da população de fotorreceptores de serpentes diurnas ....... 101

Tabela 7. Análises estereológicas da população de fotorreceptores (bastonetes e cones) de serpentes de hábitos noturnos 102

Tabela 8. Análises estereológicas da população cones L/M de serpentes 107

Tabela 9. Análises estereológicas da população cones UV de serpentes 107

Tabela 10. Média das densidades de fotorreceptores e de células da CCG de todas retinas quantificadas e proporção entre fotorreceptores e células da CCG estimada com base nas médias das densidades 110

Tabela 11. Variações da topografia de células da Camada de Células Ganglionates (CCG), de fotorreceptores, de Cones L/M e de cones UV nas retinas de serpentes diurnas e noturnas

Tabela 12. Espécies de serpentes utilizadas nos estudos comparativos da distribuição de neurônios da retina e tipos de especialização predominante 153

Tabela 13. Estimativas de acuidade visual obtidas a partir de dados morfológicos, e para algumas espécies, comparação com os valores obtidos a partir de registros comportamentais (tabela adaptada de Pettigrew \& Manger, 2008). 


\section{SUMÁRIO}

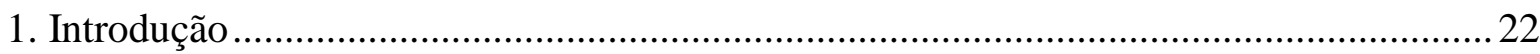

1.1. O sistema visual de vertebrados: homologias e adaptações ......................................... 22

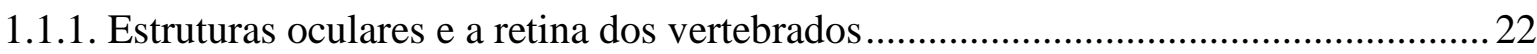

1.1.2. Fotorreceptores e os pigmentos visuais: o início do processamento visual ...............26

1.1.3. Evolução dos pigmentos visuais: adaptações aos diferentes ambientes fóticos ......... 31

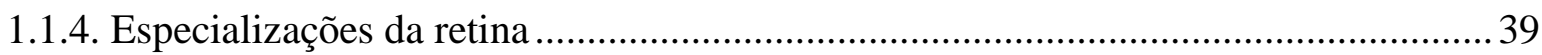

1.2. Serpentes: características do grupo e adaptações do sistema visual.............................45

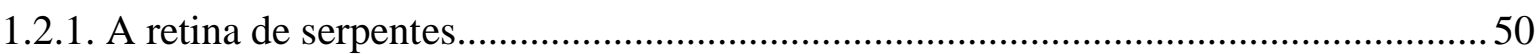

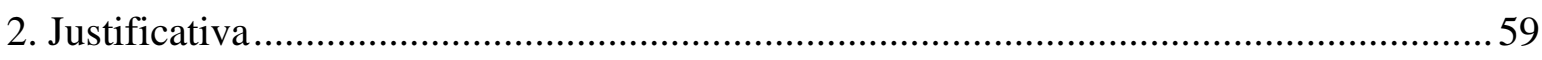

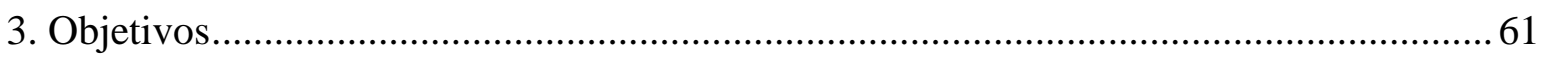

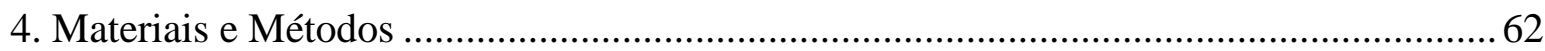

4.1. Serpentes: descrição das espécies e procedimentos com os animais.............................62

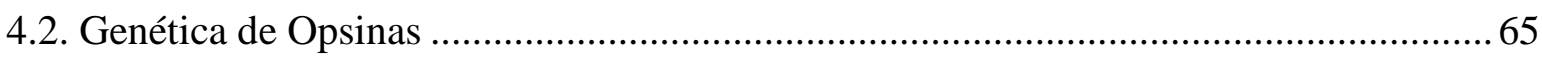

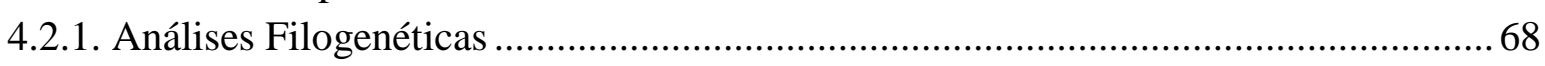

4.4.2. Estimativa das curvas de absorção espectral das opsinas ........................................69

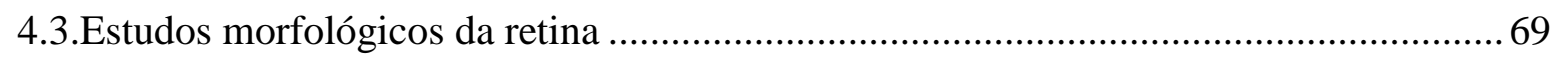

4.3.1. Técnica de Nissl para marcação de células da CCG ..............................................69

4.3.2 Técnica de Imunohistoquímica para marcação de fotorreceptores ............................ 71

4.3.3. Densidade de distribuição de neurônios nas retinas .................................................. 74

4.3.4. Avaliação da distância focal e estimativa do poder de resolução espacial..................76

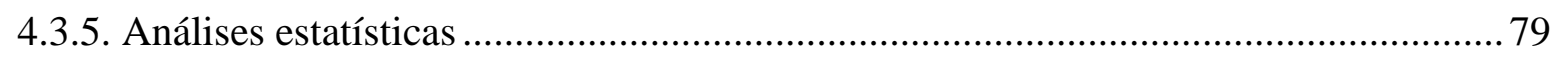

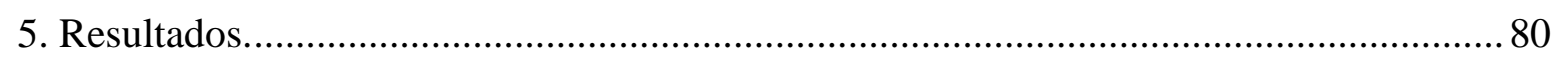

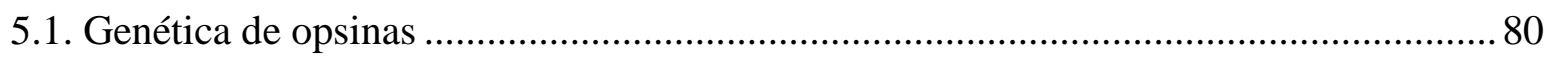

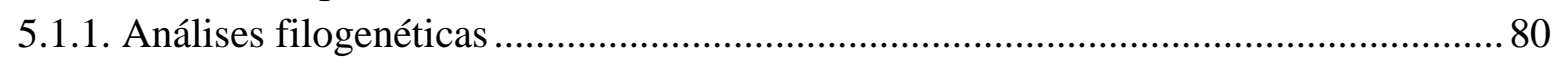

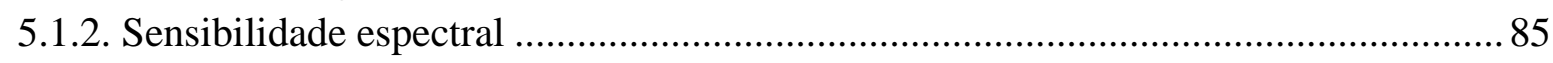

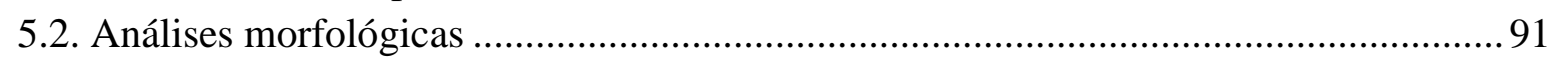

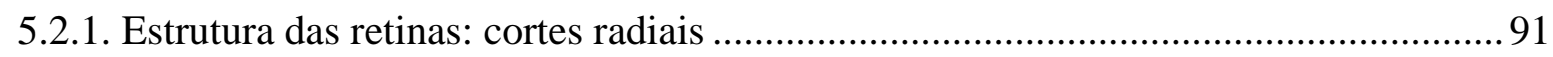

5.2.2. Densidade e topografia de neurônios...................................................................... 95

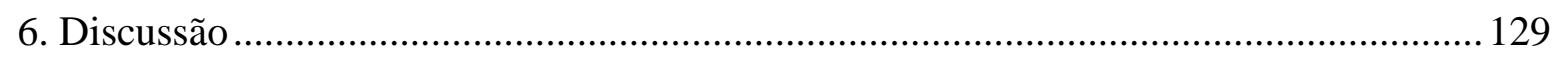

6.1. Fotorreceptores e os pigmentos visuais de serpentes Caenophidia ............................ 129

6.2. Topografia da retina e estimativa teórica do poder de resolução espacial .................. 146

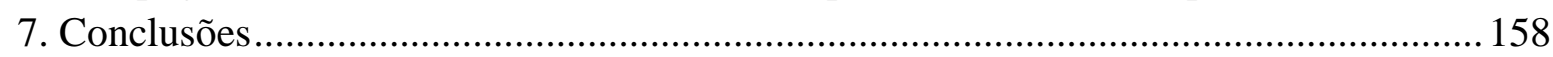

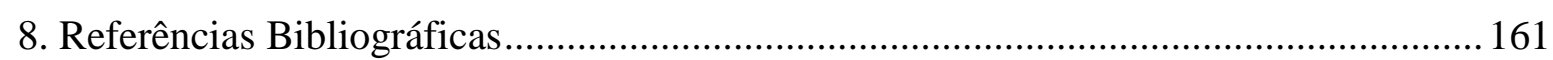

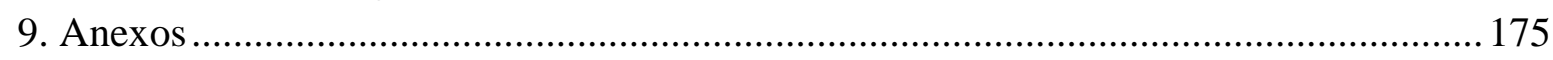




\section{INTRODUÇÃO}

\subsection{O sistema visual de vertebrados: homologias e adaptações}

A grande variedade de informações do ambiente exerce forte pressão seletiva sobre os sistemas sensoriais dos organismos, conduzindo-os por diferentes rumos adaptativos no processo evolutivo. A visão tem profundos efeitos sobre a sobrevivência das espécies, por influenciar diretamente em comportamentos vitais como a busca por alimento, a fuga de predadores e o acasalamento (Yokoyama, 2002; Davies, 2011). O sistema visual, responsável pela captação e processamento das informações luminosas do ambiente, desenvolveu-se de diferentes formas durante a história evolutiva dos animais, de acordo com a demanda das espécies (Walls, 1942). Dados obtidos por cientistas da visão ao longo do último século demonstraram que a ecologia é um fator atuante no direcionamento da evolução do sistema visual (Walls, 1942; Hughes, 1977; Lythgoe, 1979; Bowmaker, 1991; Yokoyama \& Yokoyama, 1996; Collin, 1999, 2008; Davies et al., 2012). Apesar do grande número de homologias das estruturas visuais dos vertebrados, diversas variações relacionadas a características ecológicas das espécies podem ser observadas.

\subsubsection{Estruturas oculares e a retina de vertebrados}

"To suppose that the eye, with all its inimitable contrivances . . . could have been formed by natural selection, seems, I freely confess, absurd in the highest degree." Charles Darwin (The Origin of Species, 1859).

Explicar a evolução de um órgão tão perfeito como o olho é um grande desafio para biólogos evolucionistas. A complexidade das estruturas oculares dos vertebrados levou Charles Darwin a dedicar um capítulo inteiro de sua tese A Origem das Espécies 
para discutir e explicar o problema. Darwin livremente admitiu que a ideia de um olho capaz de ajustar o foco a diferentes distâncias, permitir a entrada e o processamento de diferentes quantidades de luz e corrigir aberrações esféricas e cromáticas, ter sido formado por seleção natural, pareceria intuitivamente absurda. No entanto, posteriormente, ele encontrou uma maneira de solucionar o dilema, sugerindo que um protótipo ocular, um olho simples e imperfeito, teria gradualmente dado origem a órgãos visuais mais perfeitos, pela variação (mutação) e pela seleção natural (Gehring \& Ikeo, 1999).

O globo ocular dos vertebrados é constituido por três camadas dispostas concentricamente: a esclera, a úvea e a retina. A esclera constitui a camada mais externa, e é composta por fibras colágenas altamente interconectadas que dão suporte e sustentação ao olho. Na parte anterior do olho, as fibras da esclera assumem uma conformação ordenada que confere transparência à esclera, formando a córnea, uma lente pela qual passa a luz que atinge a retina. A córnea, em conjunto com o cristalino, uma segunda lente situada entre a câmara anterior e o humor vítreo, substância gelatinosa que preenche o globo ocular, possibilita a focalização da imagem no plano da retina. A camada mediana, ou úvea, formada pela íris, corpo ciliar e coróide, provê nutrientes para a camada mais interna, a retina, tecido formado por uma rede de células nervosas e gliais (Figura 1). 


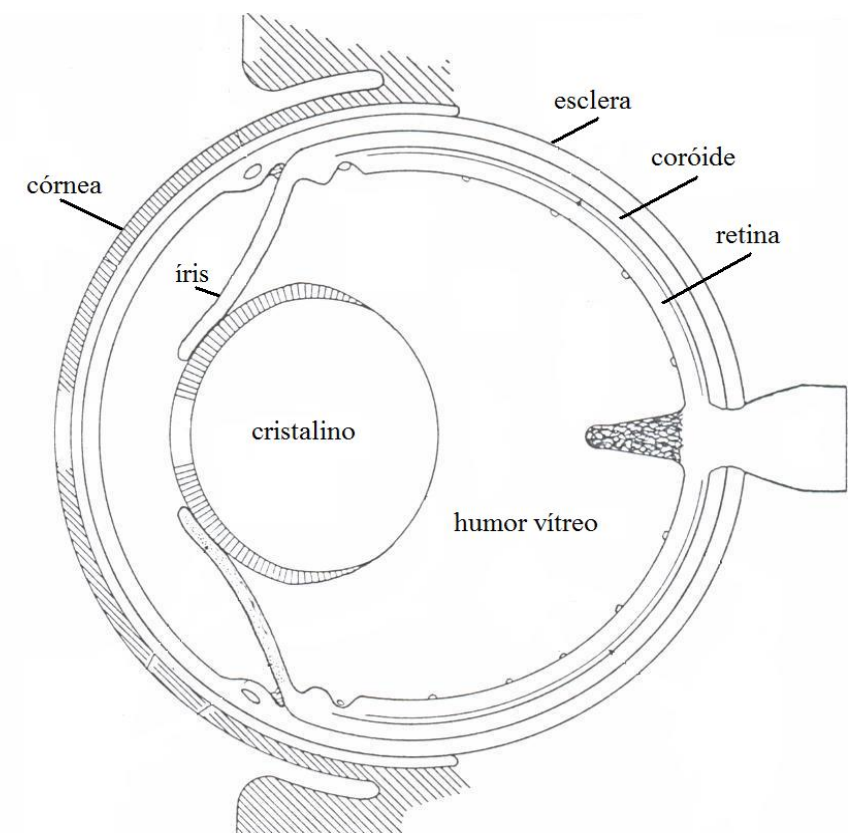

Figura 1. Corte sagital de olho de serpente (Walls, 1942).

Em 1893 o neuroanatomista espanhol Santiago Ramón y Cajal publicou uma descrição detalhada da organização laminar da retina dos vertebrados, composta por dez camadas bem definidas, correspondentes a camada do epitélio pigmentado, aos fotorreceptores, aos corpos celulares localizados nas camadas nucleares, os prolongamentos dos neurônios nas camadas plexiformes e a células gliais formando as membranas limitantes (Figura 2).

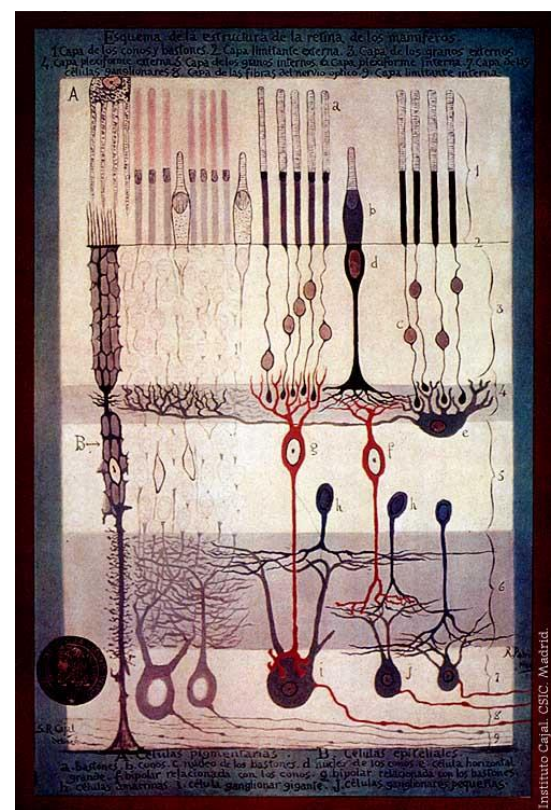

Figura 2. Estrutura da retina de mamíferos (Ramón y Cajal, 1990). 
O padrão organizacional em camadas da retina pode ser observado em todos os vertebrados, conforme ilustrado na Figura 3: 1. Camada do Epitélio Pigmentado (CEP), formado por células epiteliais com grânulos de pigmento; 2. Camada dos Fotorreceptores (CF), com seus segmentos externos e internos; 3. Membrana Limitante Externa (MLE), formada pelos prolongamentos das células de Müller; 4. Camada Nuclear Externa (CNE), com os núcleos dos fotorreceptores; 5. Camada Plexiforme Externa (CPE), onde ocorre contato sináptico entre fotorreceptores e células bipolares e horizontais; 6. Camada Nuclear Interna (CNI), com os corpos celulares de células bipolares, amácrinas, horizontais e de Müller; 7. Camada Plexiforme Interna (CPI), onde ocorre o contato sináptico entre células bipolares e amácrinas e as células ganglionares; 8. Camada de Células Ganglionares (CCG), com os corpos celulares das células ganglionares e de células amácrinas deslocadas; 9. Camada de Fibras Nervosas (CFN), com axônios das células ganglionares; 10. Membrana Limitante Interna (MLI), formada por prolongamentos das células de Müller.

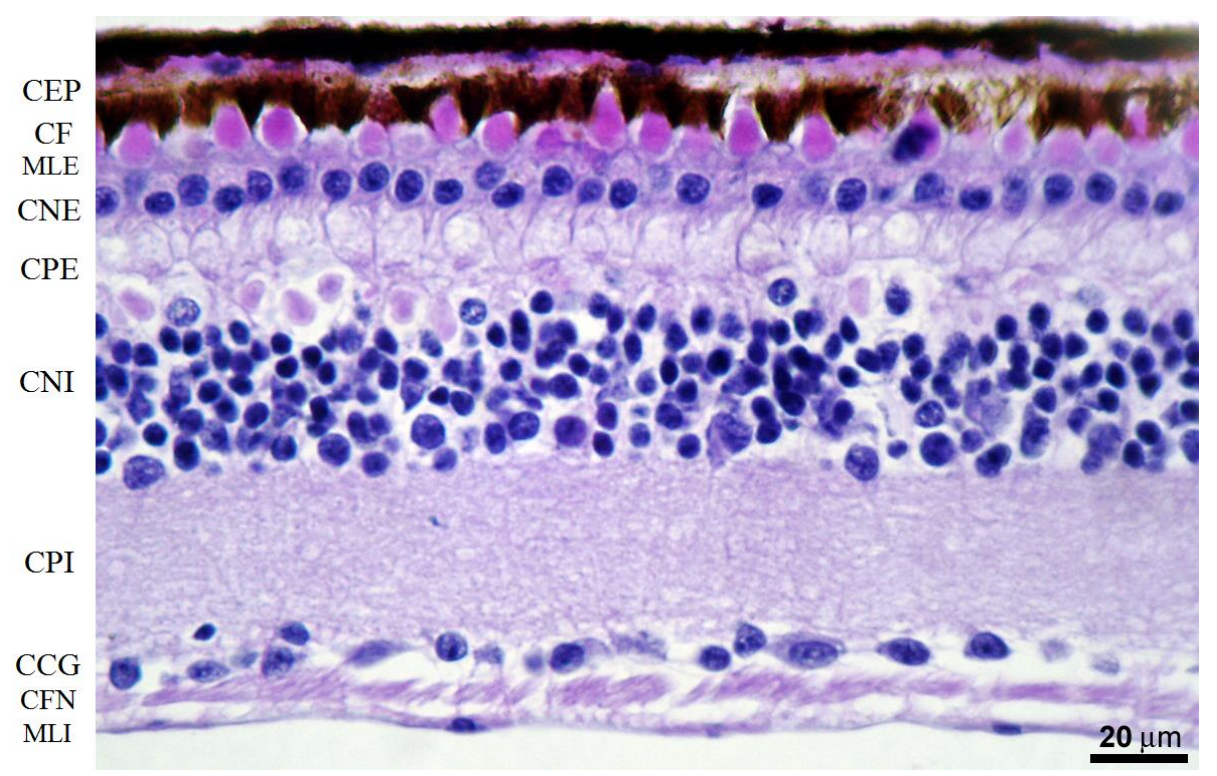

Figura 3. Corte histológico de retina da serpente Philodryas olfersii, com as dez camadas características da retina dos vertebrados. Coloração: Hematoxilina-Eosina. CEP, camada do epitélio pigmentado; CF, camada de fotorreceptores; MLE, membrana limitante externa; CNE, camada nuclear externa; CPE, camada plexiforme externa; CNI, camada nuclear interna; CPI, camada plexiforme interna; CCG, camada de células ganglionares; CFN, camada de fibras nervosas; MLI, membrana limitante interna (Hauzman et al., 2014). 


\subsubsection{Fotorreceptores e os pigmentos visuais: o início do processamento visual.}

O processamento visual se inicia com a interação entre fótons e os fotorreceptores, neurônios especializados em captar e converter a energia luminosa em energia eletroquímica, e este sinal visual é conduzido aos centros visuais via nervo óptico (Ramón y Cajal, 1893). Os fotorreceptores possuem quatro regiões distintas: segmento externo, segmento interno, núcleo e terminal sináptico (Figura 4). Os fotorreceptores são classificados em cones, com segmento externo cônico e terminal sináptico em forma de pedículo, ou bastonetes, com segmento externo cilíndrico e terminal sináptico em forma de esférula (Underwood, 1970; Ali \& Klyne, 1985).

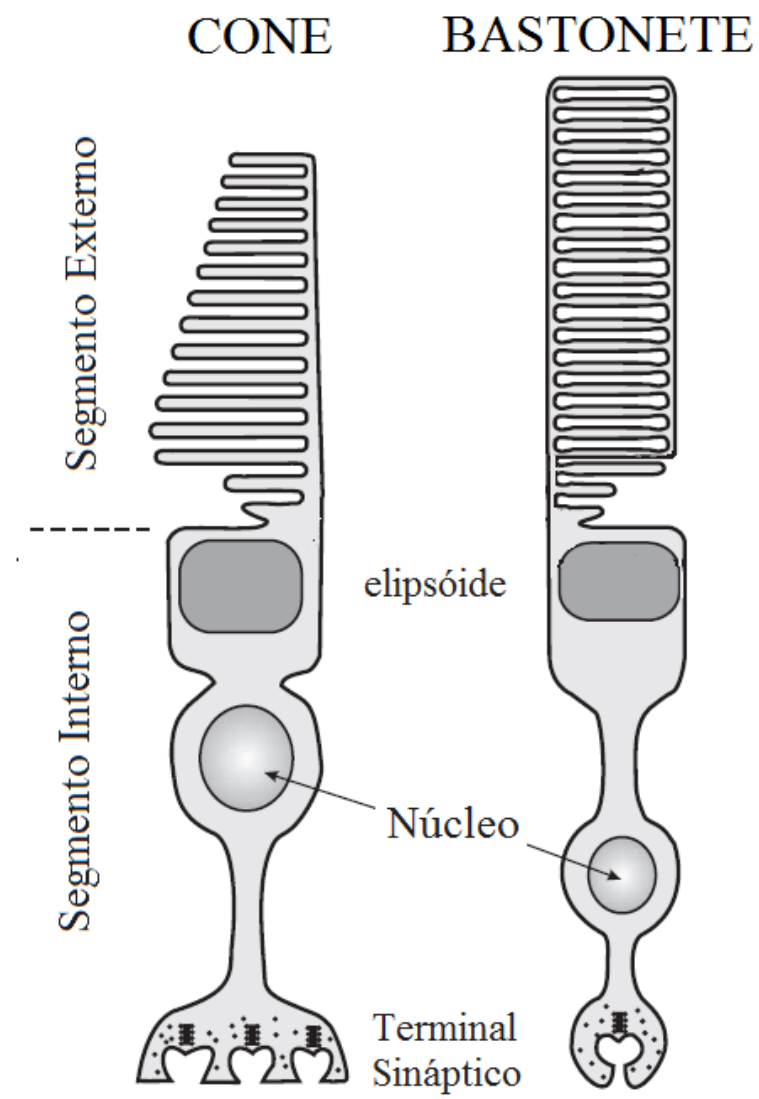

Figura 4. Representação de corte transversal de fotorreceptores da retina de vertebrados (modificado de Burns \& Lamb, 2003). 
O segmento externo dos fotorreceptores é constituído por discos membranosos empilhados contendo moléculas de pigmentos fotossensíveis, ou pigmentos visuais, formados por uma proteína de membrana acoplada a um cromóforo, responsável pela absorção de fótons e início do processamento visual (Figura 5) (Bowmaker, 1991). O maior número de fotopigmentos nos bastonetes proporciona maior capacidade de absorção de fótons, o que torna estas células mais sensíveis à luz. Desta forma, os bastonetes compõem o sistema de visão escotópico (noturno), de alta sensibilidade por ter grande capacidade de captação de luz e de amplificação do sinal de gerado por único evento de fotoizomerização e a grande convergência sináptica, com muitos bastonetes ligados a uma célula ganglionar, através das células bipolares, porém com uma baixa acuidade visual, devido ao alto grau de convergência. O sistema de visão fotópico (diurno) mediado pelos cones, tem menor sensibilidade, porém maior acuidade visual (Dowling, 1987; Bowmaker, 1991). Durante o dia, com a alta intensidade luminosa, os bastonetes são constantemente saturados, enquanto os cones estão ativados. De noite, os bastonetes funcionam com a iluminação abaixo do limiar de ativação dos cones (Turner \& Manister, 2008). Animais noturnos geralmente apresentam retinas com predominância de bastonetes, enquanto animais diurnos possuem maior quantidade de cones. 


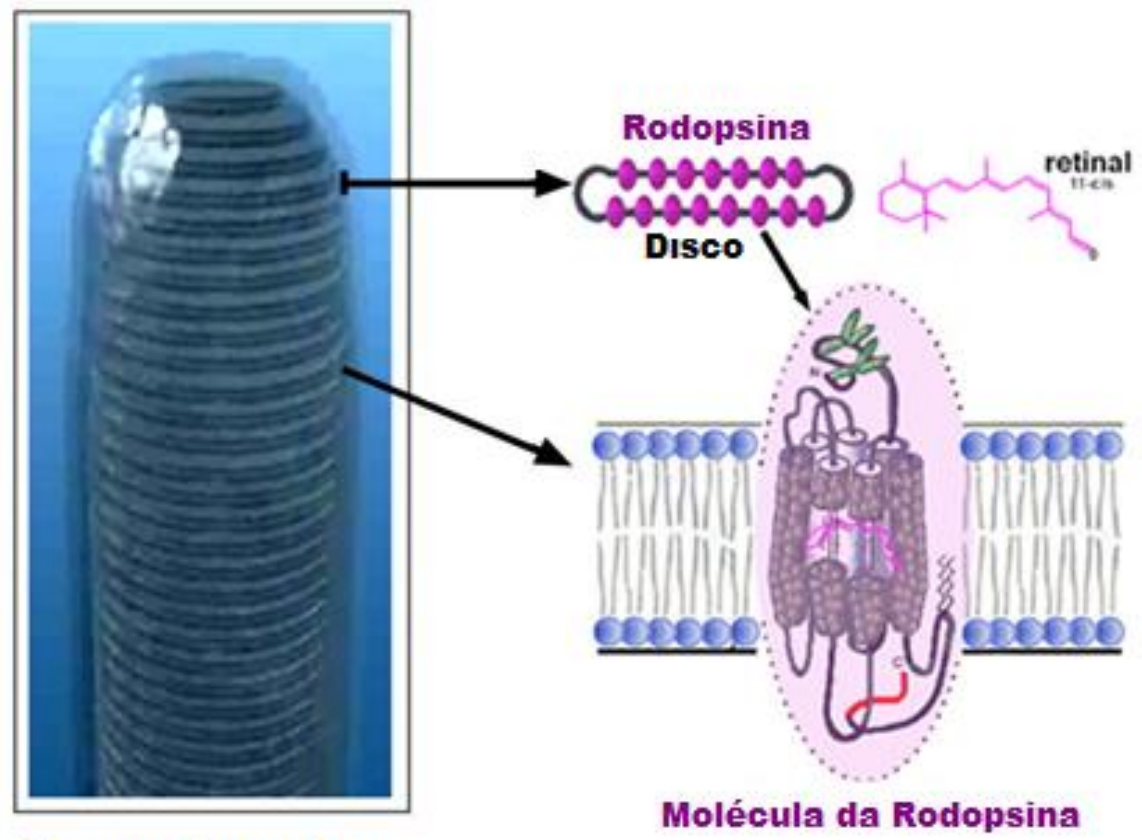

\section{Segmento externo}

Figura 5. Diagrama esquemático do segmento externo de um bastonete e a opsina inserida na membrana plasmática (modificado de: http://webvision.med.utah.edu/photo1.html\#outer).

Os pigmentos visuais, presentes nos segmentos externos dos fotorreceptores, fazem parte do grupo de receptores de membrana acoplados à proteína $\mathrm{G}$ (Strader et al., 1994; Yokoyama \& Starmer, 1996). Cada pigmento visual consiste em uma proteína de membrana integral, a opsina, ligada a um cromóforo fotossensível derivado da vitamina A, o 11-cis-retinal ou o 11-cis-3-4-dehydroretinal. A absorção de um fóton pelo cromóforo provoca a sua isomerização e mudança na configuração espacial, da forma 11-cis-retinal ou 11-cis-retinaldeido para a forma all trans (Figura 6). A proteína de membrana adquire então sua forma ativada (Burns \& Lamb, 2003), o que desencadeia uma cascata de reações enzimáticas no interior da membrana, levando ao fechamento de canais de cátions. O fechamento destes canais leva à alteração da polaridade da membrana do fotorreceptor e a hiperpolarização da célula, o que altera a taxa de liberação de neurotransmissores para as células horizontais e bipolares da retina. Através dos axônios das células ganglionares, os quais formam o nervo óptico, os sinais visuais são conduzidos ao córtex. 
A<smiles>CC1=C(C)C(/C=C/C(C)=C/C=C/C(C)=C/C=C/C(C)=C/C=O)=C(C)C(C)(C)C=C1</smiles>

B

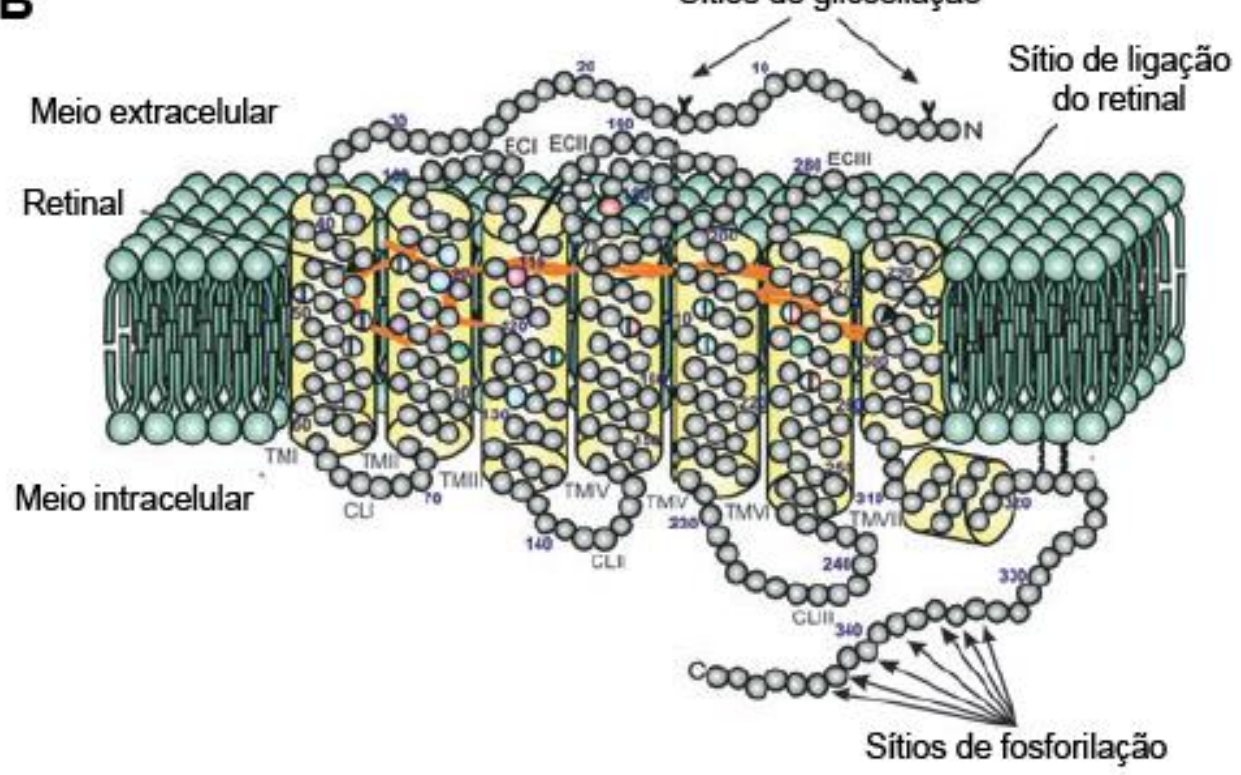

C

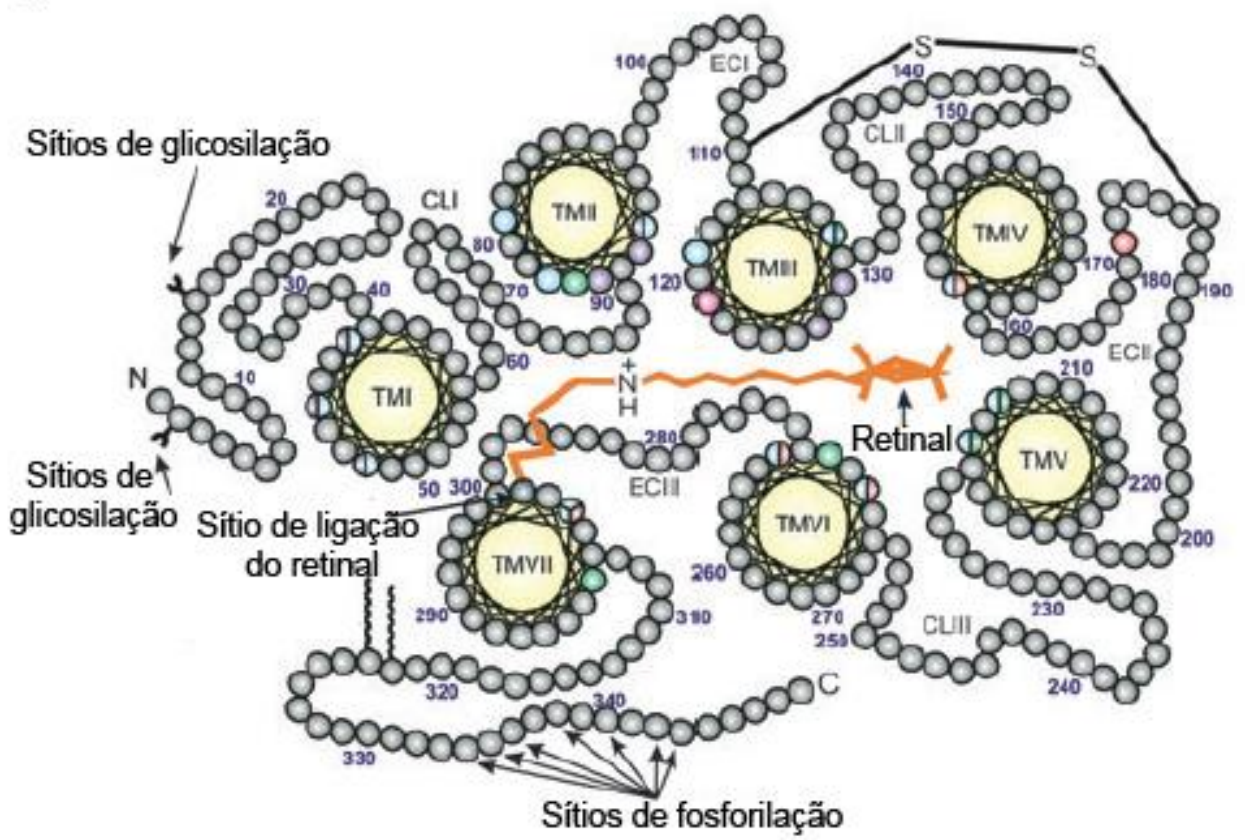

Figura 6. Diagrama da estrutura do pigmento visual de vertebrados. (A) O passo inicial da fototransdução consiste na absorção de um fóton pelo 11-cis retinal, que se converte para a forma all-trans retinal. (B) visão lateral de um fotopigmento mostrando a presença de sete domínios transmembranares, típicos da superfamília de receptores acoplados à proteína $\mathrm{G}$ e $(\mathrm{C})$ seção da membrana, mostrando o seu arranjo ao redor do cromóforo retinal (laranja). TM, transmembrana; CL, loop citoplasmático; EC, loop extra celular. A numeração é baseada na sequência da rodopsina bovina (RH1) (modificado de Davies et al., 2012). 
Codificadas por genes específicos, as opsinas são compostas por cerca de 350 aminoácidos, que formam um canal com sete regiões transmembranares em $\alpha$-hélice. $\mathrm{O}$ cromóforo se liga covalentemente a um resíduo Lisina no sítio 296 (K296), específico da opsina, via base de Schiff protonada, na sétima hélice transmembranar (Figuras 6 e 7) (Wald, 1935, 1955, 1968). Quando colocado em solução o 11-cis-retinal absorve luz com comprimento de onda máximo $\left(\lambda_{\max }\right)$ em $440 \mathrm{~nm}$ (Kito et al., 1968); entretanto, devido a interação com os aminoácidos das opsinas, este pico de absorção pode sofrer alterações em uma faixa que varia entre 350 e $560 \mathrm{~nm}$ (Yokoyama, 2008). Desta forma, cada pigmento visual tem uma sensibilidade espectral máxima particular e este valor é determinado pela interação direta ou indireta do cromóforo com aminoácidos em sítios específicos da opsina. Diferentes estruturas da opsina resultam em diferentes valores de $\lambda_{\max }($ Sakmar \& Fahmy, 1996).

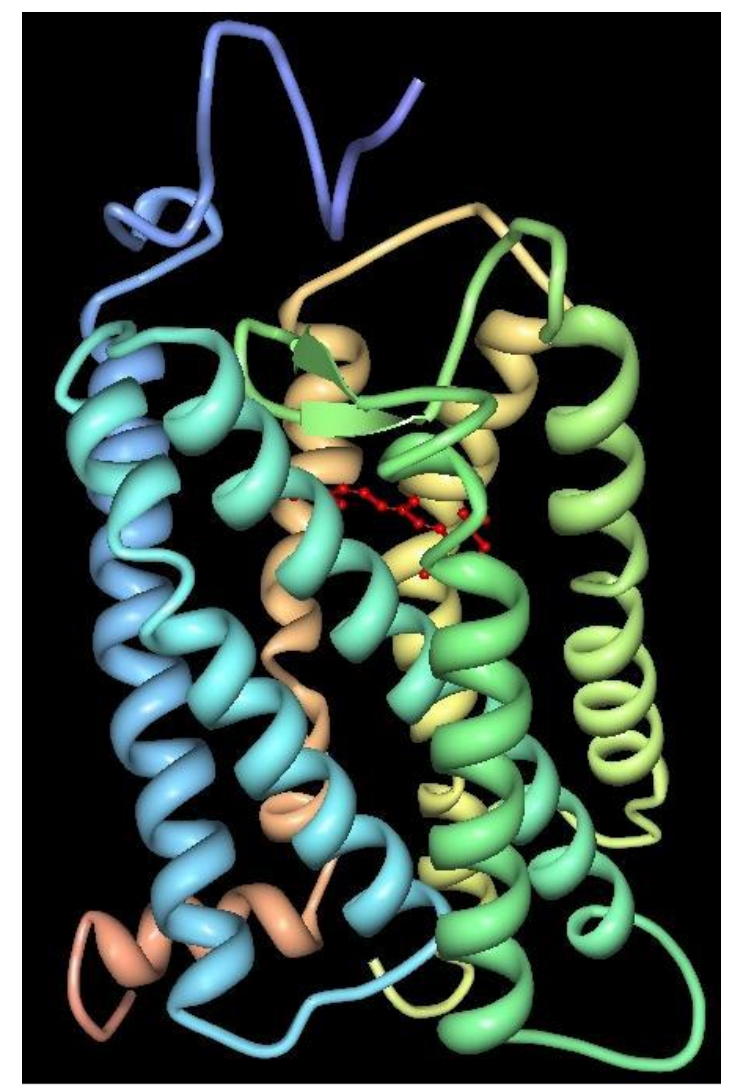

Figura 7. Estrutura tridimensional da rodopsina bovina. Os sete domínios transmembrânicos estão ilustrados em diferentes cores. O cromóforo está identificado em vermelho (Palczewski et al., 2000). 


\subsubsection{Evolução dos pigmentos visuais: adaptações aos diferentes ambientes}

\section{fóticos.}

As variações na sensibilidade dos pigmentos visuais dos vertebrados são em geral decorrentes de adaptações sofridas pelos seus ancestrais aos vários ambientes fóticos (Lythgoe, 1979). Dada a importância das vias visuais responsáveis pela formação de imagens para a sobrevivência da maioria dos vertebrados, é evidente que os genes que codificam proteínas responsáveis por mediar a visão tenham passado por forte pressão seletiva ao longo de sua história evolutiva, e que mudanças moleculares nestes genes podem ser vantajosas para a sobrevivência do organismo. Adaptações moleculares a diversos ambientes fóticos ocorreram entre os vertebrados, determinando o número, tipo e sensibilidade espectral dos pigmentos visuais presentes na retina (Davies et al., 2012; Moritz et al., 2013).

Diferentes classes de cones evoluíram a partir de duplicações de um gene de opsina ancestral (Yokoyama, 2000). A presença de mais de um tipo de cone na retina com pigmentos sensíveis a comprimentos de onda distintos, somada a um substrato neural capaz de comparar as atividades provocadas pela luz nas diferentes classes de fotorreceptores, possibilitam a discriminação de diferentes comprimentos de onda do espectro de luz visível, que são percebidos como cor (Figura 8) (Bowmaker, 1991; Bowmaker \& Hunt, 2006). Desta forma, as cores percebidas pelos animais são determinadas pela contribuição relativa de cada tipo de cone para o sinal na retina (Bowmaker, 1991; Calderone \& Jacobs, 1999; Ventura et al., 1999). Tal substrato neural capaz de comparar os sinais recebidos por cada tipo de cone, consiste em canais de oponência cromática que se estendem desde a retina até os centros visuais superiores. Em mamíferos dicromatas, por exemplo, a visão de cores é sustentada por duas classes de cones e um circuito pós-receptoral, enquanto que em espécies tricromatas três 
diferentes tipos de cones, somados a dois circuitos pós-receptorais estão presentes (De Valois, 1965). A visão de cores não é restrita ao sistema de cones. A possibilidade de participação dos bastonetes na visão de cores pode existir em condições mesópicas, com estímulos grandes em baixos níveis de intensidade (Buck et al., 2006; Thomas \& Buck, 2006).

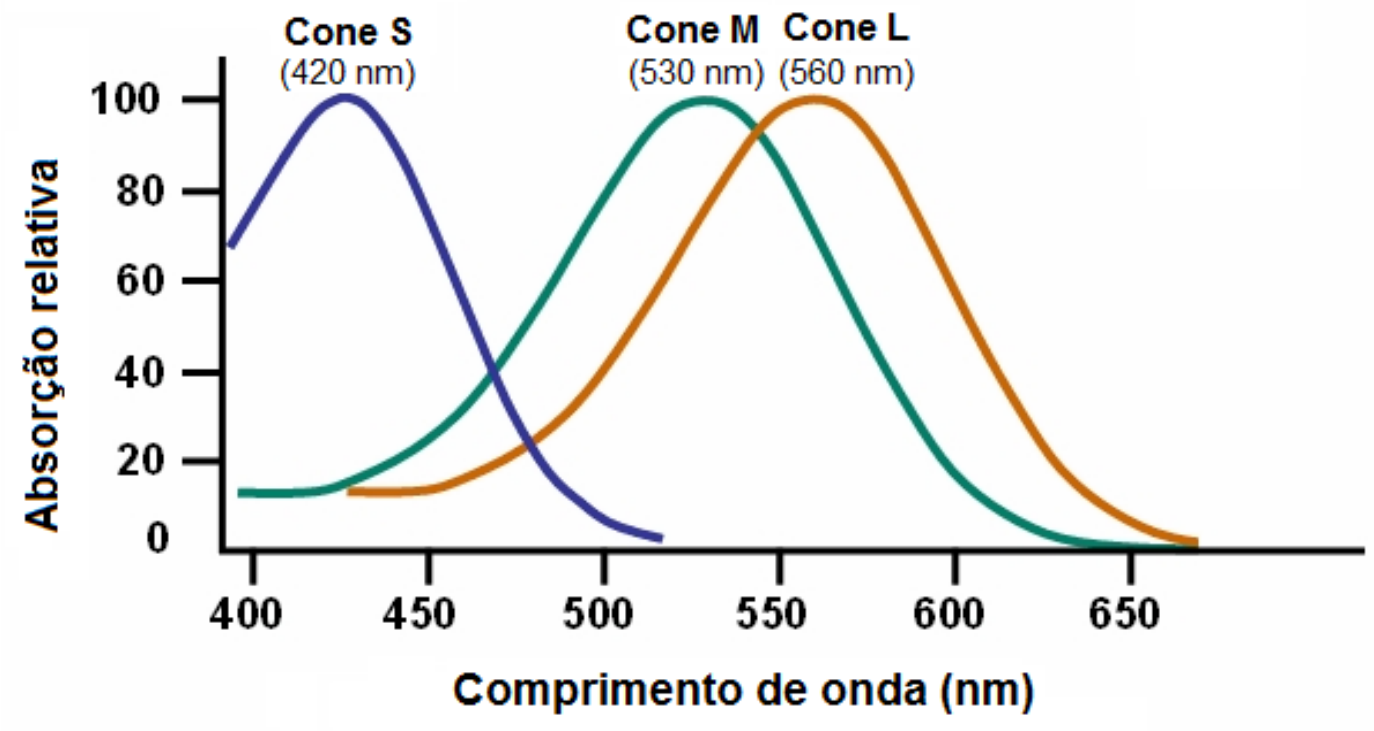

Figura 8. Pico de sensibilidade espectral dos três tipos de cones presentes na retina de humanos (modificado de Deeb \& Motulsky, 2005).

A evolução das opsinas teve grande número de mudanças nos ramos da árvore filogenética dos vertebrados. Cinco classes de pigmentos visuais retinianos foram identificados e diferenciados com base na sequência de aminoácidos, filogenia molecular e sensibilidade espectral. Análises filogenéticas dos pigmentos visuais contemporâneos mostram que vertebrados mandibulados ancestrais já possuíam estas cinco classes de pigmentos, RH1, RH2, SWS1, SWS2 e MWS/LWS, que foram gerados a partir de cinco eventos de duplicação gênica (Figura 9) (Yokoyama, 1996, 2000; Yokoyama \& Yokoyama, 1996; Ebrey \& Takahashi, 2002). A existência de duas cópias de um mesmo gene permite que uma das cópias acumule mutações e eventualmente 
resulte em um novo gene, com nova função, enquanto que a outra cópia mantém a função antiga (Ohno, 1970). Assim, as duplicações de genes, seguidas por substituições de nucleotídeos são a base para a diferenciação funcional dos cinco grupos principais de opsinas encontrados nas retinas de diferentes espécies de vertebrados atuais (Figuras 9 e 10) (Yokoyama, 1997). Muitas das espécies contemporâneas, como aves e lagartos, expressam os cinco grupos de opsinas, enquanto outras, como mamíferos, perderam alguns destes genes ao longo de sua história evolutiva (Figura 10) (Yokoyama, 2008).

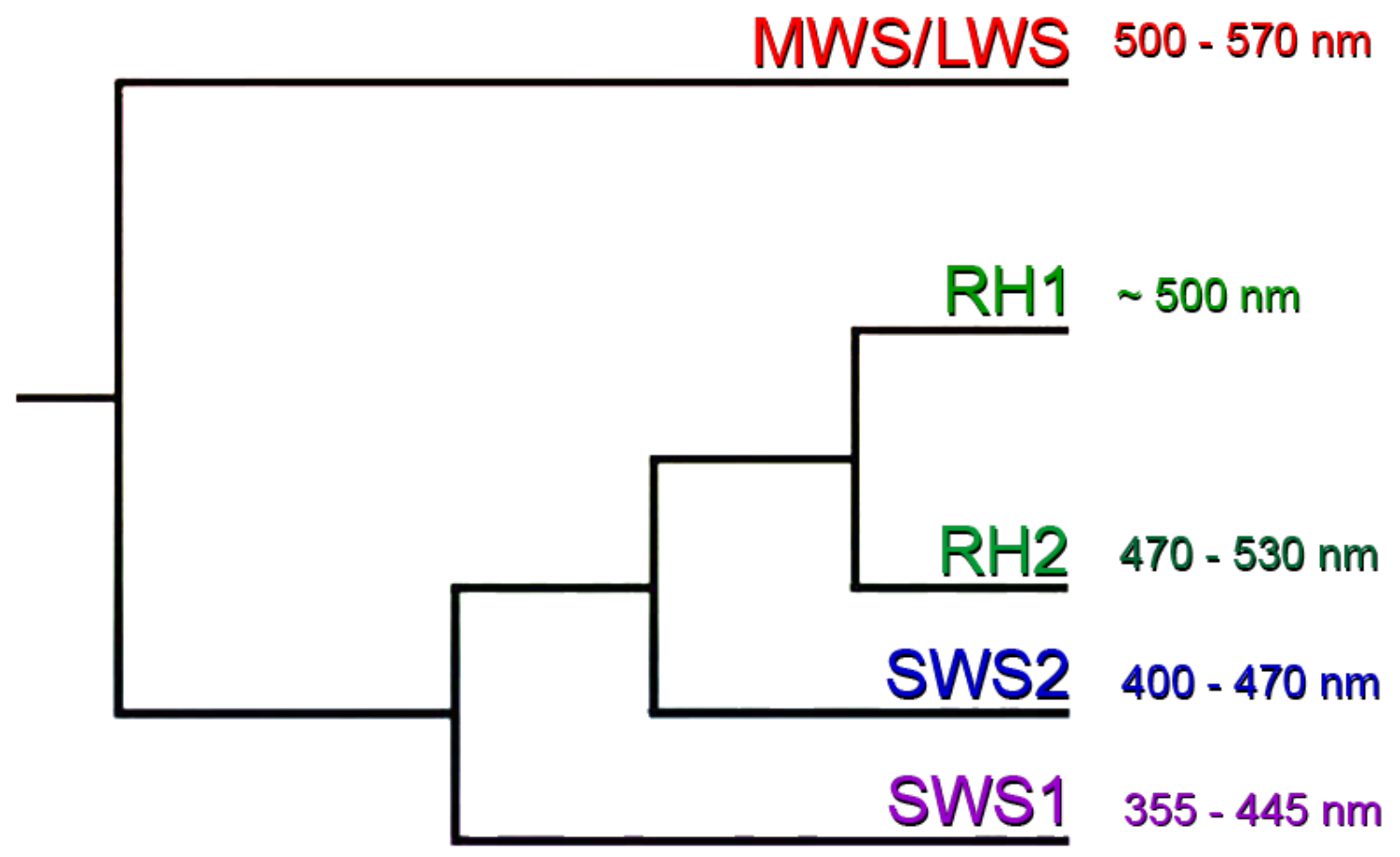

Figura 9. Relação filogenética entre os principais grupos de opsinas de vertebrados. Cinco eventos de duplicação originaram os genes MWS/LWS, SWS1, SWS2 e depois os genes RH1 e RH2 (modificado de Bailes et al., 2007). 


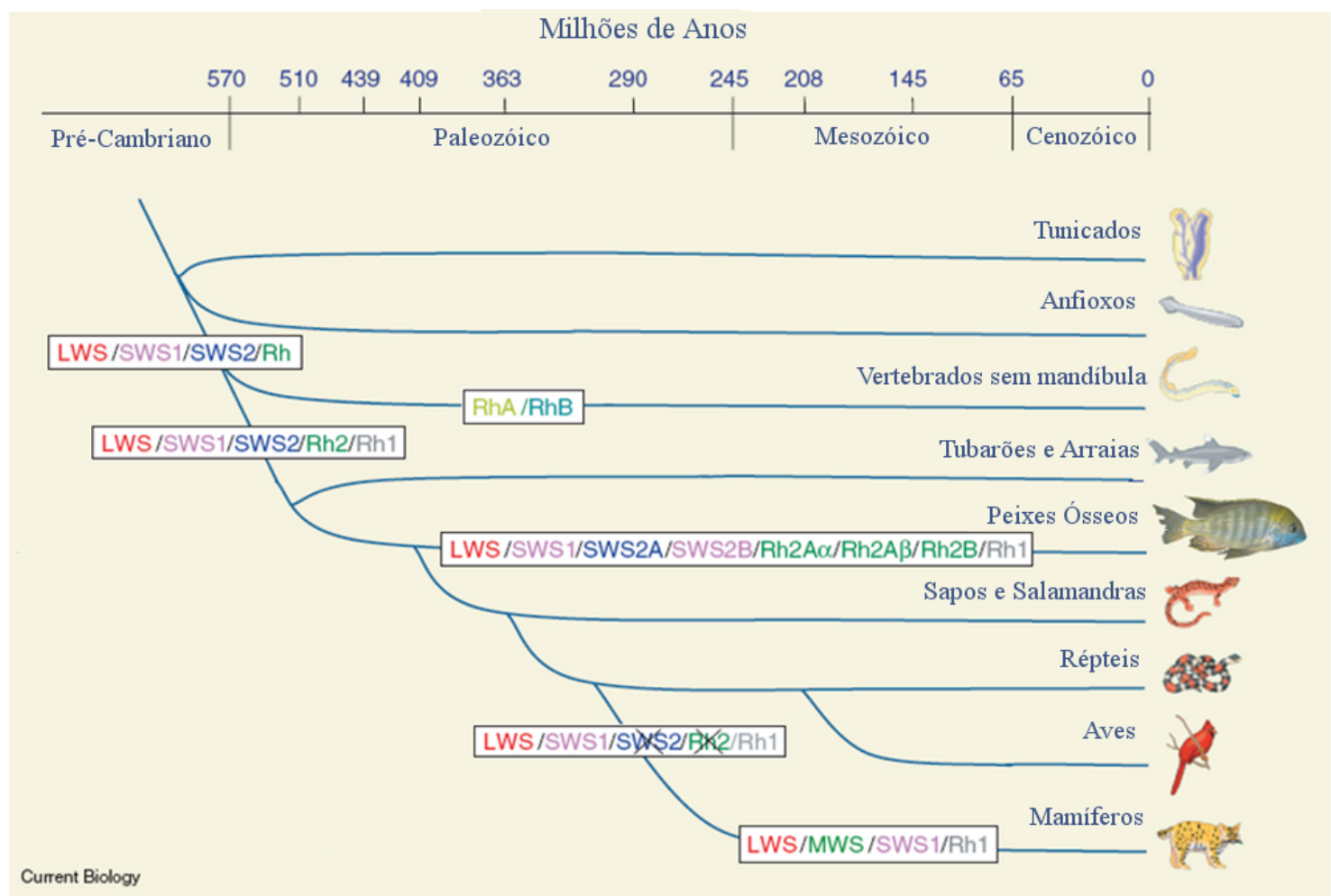

Figura 10. Reconstrução da história evolutiva dos genes de opsinas de vertebrados. Quatro genes de opsinas estão presentes no vertebrado sem mandíbula ancestral: LWS, SWS1, SWS2 e $\mathrm{Rh}$. Após a especiação dos vertebrados com mandíbulas, a opsina ancestral $\mathrm{Rh}$ sofreu uma duplicação levando a formação dos genes Rh1 e $\mathrm{Rh} 2$ no ancestral dos vertebrados mandibulados. Independentemente, o gene $\mathrm{Rh}$ sofreu uma duplicação na linhagem de vertebrados sem mandibulas, gerando os genes $\mathrm{RhA}$ e $\mathrm{RhB}$. A perda dos genes de opsinas SWS2 e Rh2 no mamífero ancestral é mostrada, bem como o recente evento de duplicação da opsina LWS de mamíferos, que originou as opsinas LWS e MWS (modificado de Tresize \& Collin, 2005).

O gene RH1 é geralmente expresso em bastonetes que possuem a rodopsina como pigmento visual, e tem valores de $\lambda_{\max }$ geralmente em torno de $500 \mathrm{~nm}$, mas que podem variar entre 480 e $510 \mathrm{~nm}$. As demais classes de opsinas são expressas em cones e sua gama espectral varia de 355 a $570 \mathrm{~nm}$. O grupo RH2 absorve comprimentos de onda médios, entre 470-530 nm. O grupo SWS1 apresenta pigmentos sensíveis a comprimentos de onda curtos, entre $355-445 \mathrm{~nm}$ e o grupo SWS2 pigmentos mais deslocados para o verde, sensíveis a comprimentos de onda entre 400-470 $\mathrm{nm}$. Os pigmentos LWS e MWS sensíveis a comprimentos de onda longos a médios são responsáveis por alcançar valores de $\lambda_{\max }$ entre 500-570 nm (Figura 9) (Hisatomi et al., 
1996; Yokoyama \& Yokoyama, 1996; Yokoyama, 2000; Ebrey \& Koutalos, 2001; Bowmaker, 2008; Davies, 2011; Davies et al., 2012).

O pigmento RH1 é mais relacionado ao RH2, e em seguida ao SWS2, SWS1 e LWS/MWS, nesta ordem (Yokoyama \& Yokoyama, 1996; Yokoyama, 1997; Yokoyama, 2000) (Figura 9). Através de estimativas da taxa de divergência dos genes, foi sugerido que o surgimento das quatro classes de opsinas de cones (LWS, SWS1, SWS2 e RH), ocorreu muito precocemente na história evolutiva dos vertebrados, há cerca de 450 milhões de anos atrás, pouco antes do surgimento de vertebrados com mandíbulas (Bowmaker \& Hunt, 2006). Peixes primitivos sem mandíbulas, como lampréias e peixes-bruxa, apresentam genes funcionais das quatro classes de cones (Bailes et al., 2007). Por outro lado, os genes RH1 e RH2 surgiram por duplicação do gene de opsina ancestral RH, após a separação dos peixes mandibulados (tubarões e arraias) dos agnatas, peixes sem mandíbula (Figura 10). Desta forma, a visão de cores evoluiu antes nos vertebrados sem mandíbula, enquanto a visão adaptada a ambientes de baixa luminosidade surgiu posteriormente, apenas depois da separação destes dois grupos (Collin et al., 2003).

\section{Genética dos pigmentos visuais: mutações e suas consequências}

As análises genéticas dos pigmentos visuais tiveram início com a clonagem de genes de opsinas bovino e humano (Nathans \& Hogness, 1983, 1984; Nathans et al., 1986). A disponibilidade desses clones permitiu o isolamento de outros genes ortólogos e parálogos de várias espécies (Yokoyama, 2002). Opsinas reconstituidas com o 11-cisretinal em cultura de células permitiram medir in vitro a sensibilidade espectral dos pigmentos visuais (Oprian et al., 1987; Nathans, 1990a,b). Com base neste desenvolvimento hipóteses evolutivas puderam ser testadas a partir da reconstrução de 
pigmentos visuais, por meio da técnica de mutagênese sítio-direcionada (site-directed mutagenesis), na qual aminoácidos específicos são incorporados em opsinas existentes. Isto permite determinar como estes aminoácidos específicos afetam de fato a visão de cores. O uso de ensaios in vitro permite, portanto, estimar o efeito de uma única ou de múltiplas mudanças de aminoácidos, sobre o deslocamento espectral (Yokoyama, 2002). De modo geral, os resultados destes ensaios in vitro estão de acordo com os dados de absorção espectral dos pigmentos visuais obtidos a partir de métodos fisiológicos (Lythgoe, 1972; Jacobs, 1993; Yokoyama, 1997).

Em muitos casos, o deslocamento espectral dos pigmentos visuais é determinado pela mudança de aminoácidos em poucos sítios específicos. O pico de sensibilidade espectral do pigmento RH1, por exemplo, é alterado por mudanças em sete sítios, D83, E122, M207, H211, W265, A292 e A295, numerado com base na sequência da rodopsina bovina (Yokoyama, 2000) (Figura 11). A combinação DEMHWAA desses aminoácidos gera pico de sensibilidade espectral $\lambda_{\max }$ de $500 \mathrm{~nm}$. As mutações D83N, E122Q e A292S, levam ao deslocamento espectral da rodopsina para o azul, em até 6, 19 e $10 \mathrm{~nm}$, respectivamente (Yokoyama, 2000); a combinação dos aminoácidos NQS nestes três sítios origina uma rodopsina com pico de sensibidade em cerca de $465 \mathrm{~nm}$. 


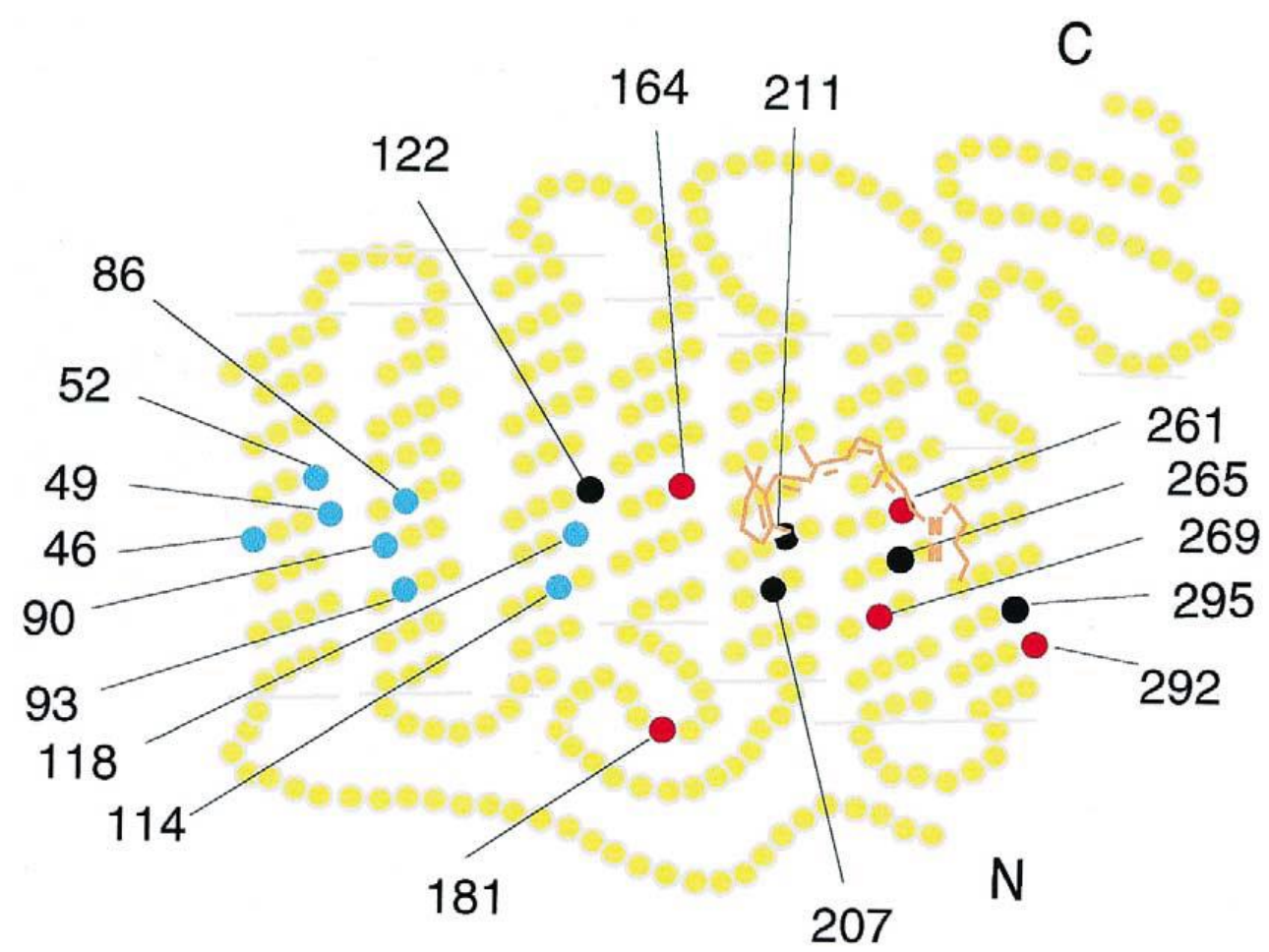

Figura 11. Estrutura secundária da rodopsina RH1 bovina, mostrando mutações de aminoácidos que ocorrem naturalmente e causam deslocamento significativo do $\lambda_{\max }$. $\mathrm{O}$ modelo é baseado em Palczewski et al. (2000). Círculos azuis, vermelhos e pretos indicam os sítios envolvidos no deslocamento dos pigmentos SWS1, LWS/MWS e RH1/RH2, respectivamente. O 11-cis-retinal está mostrado em laranja (Yokoyama, 2002).

Os pigmentos visuais sensíveis ao comprimento de onda curto dos vertebrados são divididos em duas classes, SWS1 e SWS2. O pigmento SWS1, por sua vez, pode ser subdividido em VS, sensível ao violeta, com $\lambda_{\max }$ entre 400 e $430 \mathrm{~nm}$, e UVS, sensível ao ultravioleta, com $\lambda_{\max }$ entre 355 e $380 \mathrm{~nm}$. Muitos peixes, anfibios, répteis, aves e alguns mamíferos utilizam a visão UV para atividades como forrageamento (Burkhardt, 1982; Viitala et al., 1995), busca de parceiro para acasalamento e para navegação (Bennett et al., 1996, 1997).

A evolução e os mecanismos de deslocamento espectral das opsinas SWS1 parecem ser mais complexas do que os das outras classes de opsinas. Quando as sequências de aminoácidos dos sítios específicos importantes para o deslocamento espectral de vários pigmentos SWS1 são comparadas, nenhum aminoácido comum parece ser responsável por determinar o pico de sensibilidade UV, sugerindo que o seu 
ajuste espectral em vários vertebrados tenha sido alcançado por mutações em diferentes sítios (Yokoyama, 2002). Evidências filogenéticas indicam que o pigmento ancestral era UVS e que pigmentos VS evoluiram a partir de mutações nos genes que expressam os pigmentos UVS nas diferentes linhagens de vertebrados (Cowing et al., 2002). Em aves, entretanto, a sensibilidade UV foi readquirida a partir de um ancestral VS e os sítios responsáveis pelo deslocamento espectral neste grupo são distintos dos demais vertebrados. Nas aves, a mutação S90C parece ser responsável pela evolução dos pigmentos UVS (Yokoyama et al., 2000; Wilkie et al., 2000). Entretanto, uma vez que os pigmentos UVS de outras classes de vertebrados, como peixes teleósteos (Johnson et al., 1993; Vihtelic et al., 1999), anfibios (Ma et al., 2001), répteis (Kawamura \& Yokoyama, 1996, 1998) e mamíferos (Chiu et al., 1994; Zhao et al., 1997), possuem S90, o papel central do aminoácido C90 no deslocamento para o UV parece ser limitado a pigmentos UVS de aves, e mutações em outros sítios devem ser responsáveis pelo deslocamento espectral destes dois pigmentos em outros grupos de vertebrados (Cowing et al., 2002).

Construindo uma série de mutantes quiméricos entre os pigmentos SWS1 de camundongo, com $\lambda_{\max }$ de $359 \mathrm{~nm}$ (Yokoyama et al., 1998) e de humano, com $\lambda_{\max }$ de 414 nm (Fasick et al., 1999), a causa da diferenciação entre os pigmentos UVS e VS parece ser determinada por sete aminoácidos (Yokoyama \& Shi, 2000) (Figura 11). De fato, o pigmento UV de camundongo, com as sete mutações, F46T, F49L, T52F, F86L, T93P, A114G e S118T, alcança $\lambda_{\max }$ de $411 \mathrm{~nm}$, enquanto o pigmento humano com as mutações reversas, alcançam $\lambda_{\max }$ de $360 \mathrm{~nm}$. Por outro lado, comparações de sequências de aminoácidos nos pigmentos UVS de peixes teleósteos, anfíbios, répteis e roedores, mostraram que o sítio 86 é invariavelmente ocupado pelo aminoácido Phe, mas é substituido por Tyr nos pigmentos VS de bovinos e suínos. A substituição F86Y é 
suficiente para deslocar o $\lambda_{\max }$ do pigmento do peixe dourado de $360 \mathrm{~nm}$ para cerca de $420 \mathrm{~nm}$, e a substituição reversa Y86F da opsina VS de boi, produz um deslocamento similar na direção oposta. A substituição deste único aminoácido, portanto, parece ser suficiente para justificar a evolução dos pigmentos VS, ao menos em alguns mamíferos (Cowing et al., 2002).

Para o pigmento LWS de vários grupos de vertebrados, diferenças na sensibilidade espectral podem ser caracterizadas por alterações em cinco sítios. Mudanças nos aminoácidos S180A, H197Y, Y277F, T285A e A308S deslocam o $\lambda_{\max }$ em cerca de 7, 28, 10, 16 e 18 nm, respectivamente (Yokoyama \& Radlwimmer, 1999). A regra dos "cinco sítios", explica os valores de $\lambda_{\max }$ de aparentemente todos os pigmentos verde/vermelho dos vertebrados, podendo ser aplicada também para os pigmentos verde/vermelho ancestrais (Figura 11) (Yokoyama, 2000).

\subsubsection{Especializações da retina}

Além da variação quanto aos tipos de fotorrecetores e opsinas neles expressas, diferenças marcantes na densidade e na distribuição destes e dos demais neurônios da retina são observada em análises comparativas de diferentes espécies (Hughes, 1977; Pettigrew et al., 1988; Collin \& Pettigrew, 1989; Silveira, et al., 1989; Collin, 1999, 2008; Hart et al., 2012; Coimbra et al., 2013). Dependendo do tipo celular e da espécie, a distribuição de células na retina não é homogênea. Uma maior concentração de neurônios é observada em regiões de maior demanda visual dos animais por uma boa qualidade da imagem (Hughes, 1977; Pettigrew et al., 1988; Collin \& Pettigrew, 1989; Collin, 1999, 2008; Grotzner, 2005; Pettigrew \& Manger, 2008; Hart et al., 2012; Coimbra et al., 2013). Alguns estudos revelaram que a distribuição celular se correlaciona melhor com comportamentos e com o hábitat do que com a filogenia, e que 
espécies próximas podem ter diferentes padrões de distribuição e vice-versa (Hughes, 1977; Silveira, 1985; Silveira et al., 1989; Thompson, 1991). Assim, descrições de vias de bastonetes e de cones transcendem as diferentes ordens de vertebrados, e espécies filogeneticamente relacionadas podem ter diferentes organizações dos elementos neurais.

As especializações podem ser classificadas como faixas ou estrias visuais, area centralis e fóveas (Walls, 1942; Brown, 1969; Collin, 2008). As faixas ou estrias são regiões alongadas de maior densidade de células e podem ser classificadas em faixa horizontal ou vertical. A faixa horizontal é comum em vertebrados que ocupam hábitats cujo campo visual é dominado pelo horizonte, como a interface ar-terra de espécies terrestres ou água-terra de espécies aquáticas (Collin, 2008). A faixa horizontal proporciona uma melhor visão panorâmica do ambiente sem que haja a necessidade de alto grau de movimentação dos olhos. Exemplos de faixas horizontais são observados em retinas da tartaruga Trachemys scripta elegans (Grotzner, 2005) e da cutia Dasyprocta aguti (Silveira et al., 1989; Rocha et al., 2009) (Figura 12).
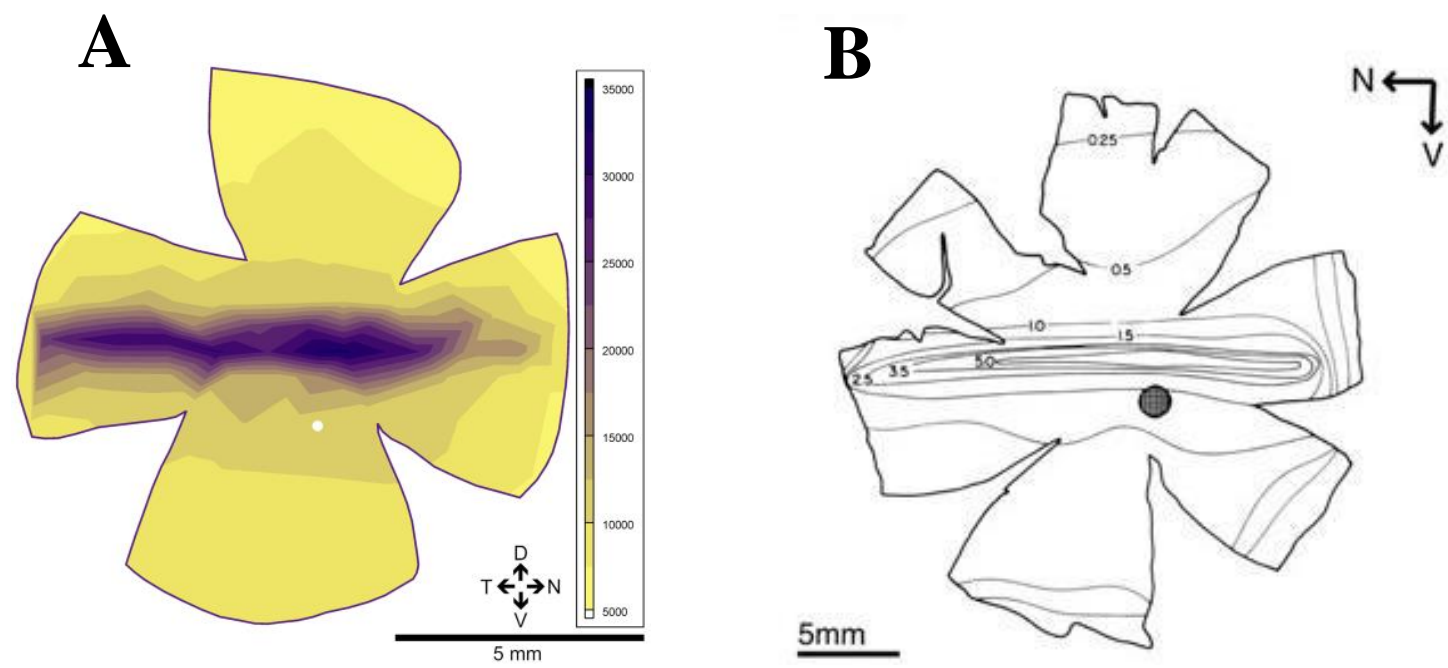

Figura 12. A. Mapa topográfico de fotorreceptores de retina de tartagura de água doce Trachemis scripta elegans, com faixa horizontal se estendendo ao longo do eixo nasal-temporal. O ponto branco representa o nervo óptico (Gotzner, 2005). B. Mapa topográfico de células da CCG em retina de cutia, Dasyprocta aguti, com faixa horizontal bem definida. Densidade $\times 10^{3}$ celulas $/ \mathrm{mm}^{2}$. O ponto escuro representa o nervo óptico (Silveira et al., 1989). D, dorsal; N, nasal; $\mathrm{T}$, temporal; $\mathrm{V}$, ventral. 
A faixa ou estria vertical, por sua vez, também é definida como um aumento alongado de densidade celular, mas que se estende ao longo do eixo dorsal-ventral da retina, e geralmente está localizada na região temporal. Esta especialização pode ser observada em retinas de espécies cujo campo visual é dominado por um caracter verticalmente orientado (Collin, 2008), como galhos de árvores vistos pelo bichopreguiça Choloepus didactylus (Andrade-Da-Costa et al., 1989) (Figura 13 A); a tromba do elefante africano Loxodonta africana (Stone \& Halasz, 1989) (Figura 13 B), ou a coluna d'água, vista por espécies que migram verticalmente como o peixe teleósteo, Howella sherborni (Collin \& Partridge, 1996).
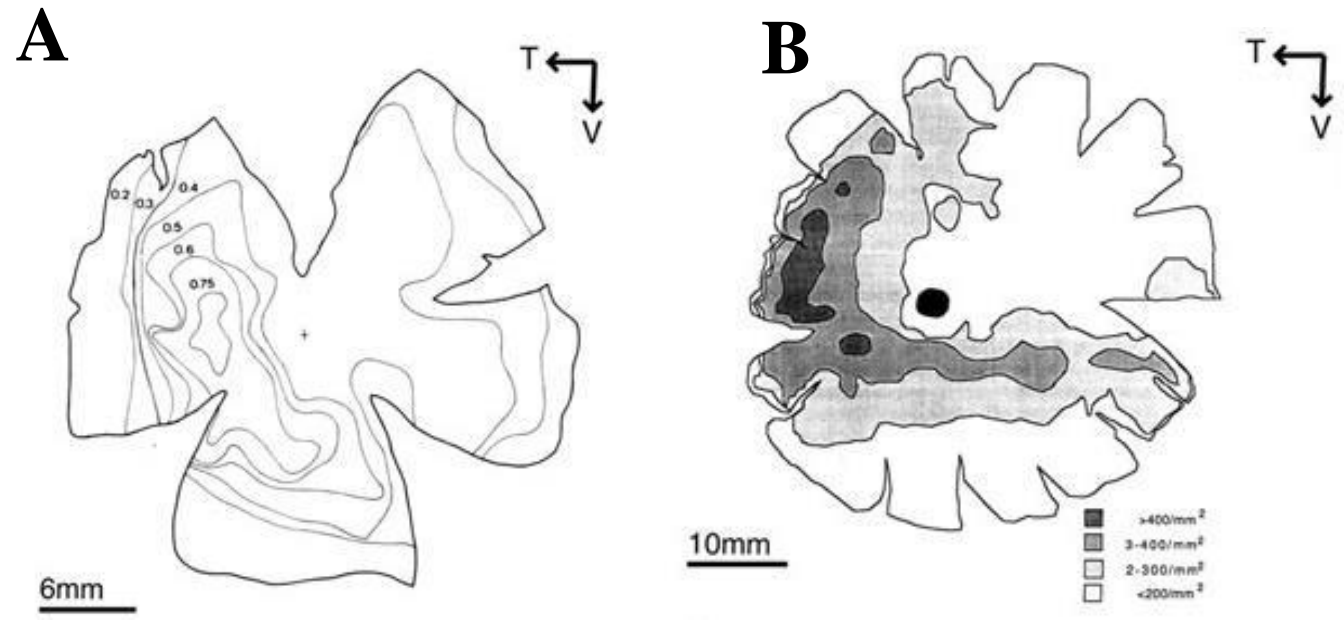

Figura 13. A. Mapa topográfico de células da CCG da retina de preguiça Choloepus didactylus, com faixa visual verticalmente orientada na região temporal. Densidade $\times 10^{3}$ celulas por $\mathrm{mm}^{2}$ (Andrade-Da-Costa et al., 1989). B. Mapa topográfico de células da CCG de retina de elefante africano, Loxodonta africana, com faixa visual verticalmente orientada na região temporal (Stone \& Halasz, 1989). T, temporal; V, ventral.

Muitas espécies de vertebrados possuem uma área de maior densidade de células da retina chamada de area centralis. Este tipo de especialização não apresenta a vantagem de percepção do campo de visão panorâmico como aquela proporcionada pela estria horizontal ou visual, e exige um maior grau de movimentação dos olhos para localizar presas e a presença de potenciais predadores (Collin, 2008). As areae cetrales estão geralmente localizadas na região temporal da retina, incluídas desta forma no 
campo de visão binocular frontal, fator este regido também pela posição dos olhos na cabeça. Em algumas espécies são observados arranjos concêntricos dos contornos de isodensidade dentro da area centralis, enquanto em outras, o arranjo celular é anisotrópico, com aumento irregular de densidade de células (Figura 14) (Collin, 2008).
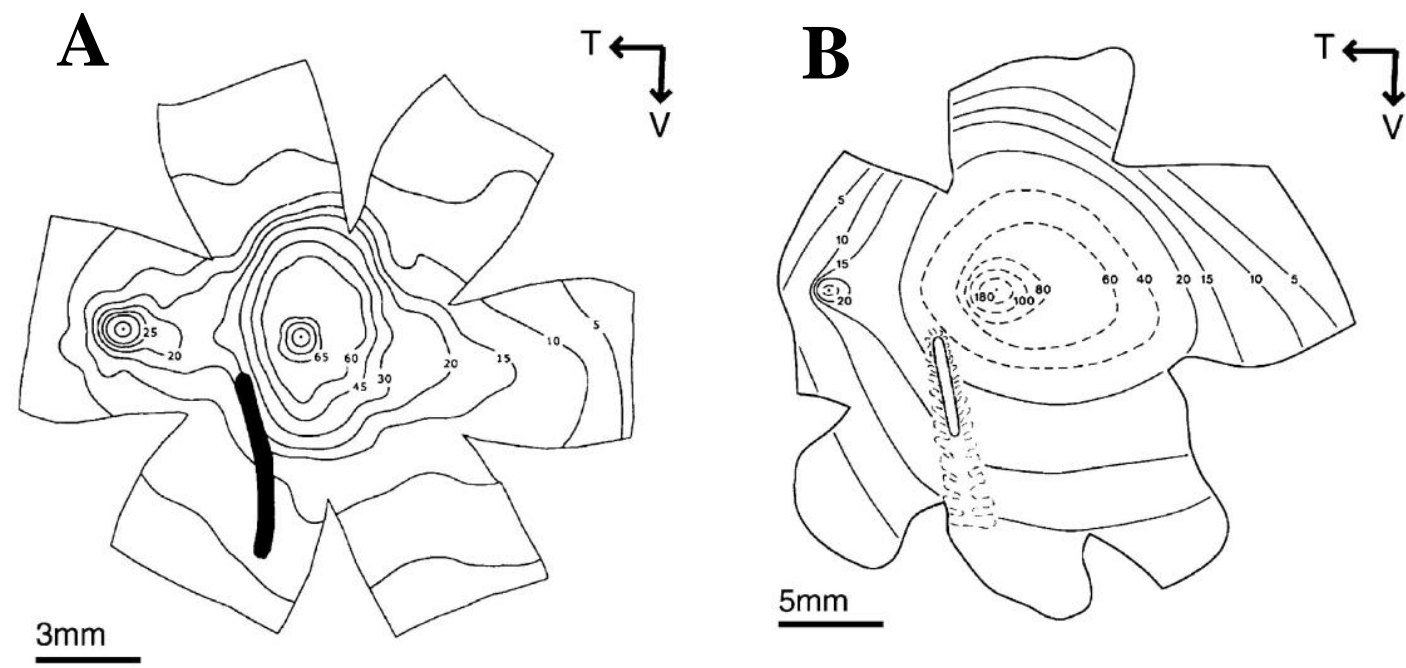

Figura 14. A. Mapa topográfico de células da CCG de retina de Myiozetes cayenensis (Aves), com area centralis na região central e fóvea temporal. Densidade $\times 10^{3}$ células por $\mathrm{mm}^{2}$ (Coimbra et al., 2006). B. Mapa topográfico de células da CCG de retina de Halcyon sancta (Aves), com area centralis na região central, fóvea nasal (monocular) e fóvea temporal (binocular). Densidade $x 10^{3}$ células por $\mathrm{mm}^{2}$ (Moroney \& Pettigrew, 1987). T, temporal; V, ventral.

De acordo com a teoria de Hughes (1977), animais terrestres que habitam campos abertos geralmente possuem uma faixa horizontal, com alta densidade de fotorreceptores e de células ganglionares. Esta faixa proporciona melhor visão panorâmica do ambiente e a detecção de objetos no horizonte sem a necessidade de movimentação dos olhos, característica esta apropriada para a visão de extensão de campo e a percepção da aproximação de predadores a longas distâncias. Espécies arborícolas ou de mata fechada, por sua vez, apresentam geralmente uma area centralis, com maior densidade de cones e células ganglionares, que aponta para melhor acuidade desta região circular. 
Alguns primatas, répteis e aves apresentam a fóvea, especialização da area centralis, caracterizada pelo deslocamento lateral das células das camadas internas da retina e um aumento da densidade de células ganglionares na região perifoveal (Collin, 2008). Na fóvea é observado um aumento da densidade de fotorreceptores com segmentos externos mais alongados e de menor diâmetro, e geralmente a presença de apenas cones, o que favorece a alta sensibilidade e maior acuidade nesta região (Walls, 1942; Brown, 1969; Granda \& Haden, 1970). A fóvea pode ser classificada em dois tipos, convexiclivada com grande declive dos dois lados da depressão, como observado em alguns peixes e aves, ou concaviclivada, com uma depressão rasa, como em macacos e humanos (Collin, 2008) (Figura 15). Quatro tipos de fóveas foram caracterizados em peixes teleósteos (Collin \& Collin, 1999). Alguns vertebrados, como aves predatórias, possuem duas fóveas, uma temporal que atua na visão binocular e uma nasal, monocular (Figura 14) (Moroney \& Pettigrew, 1987).
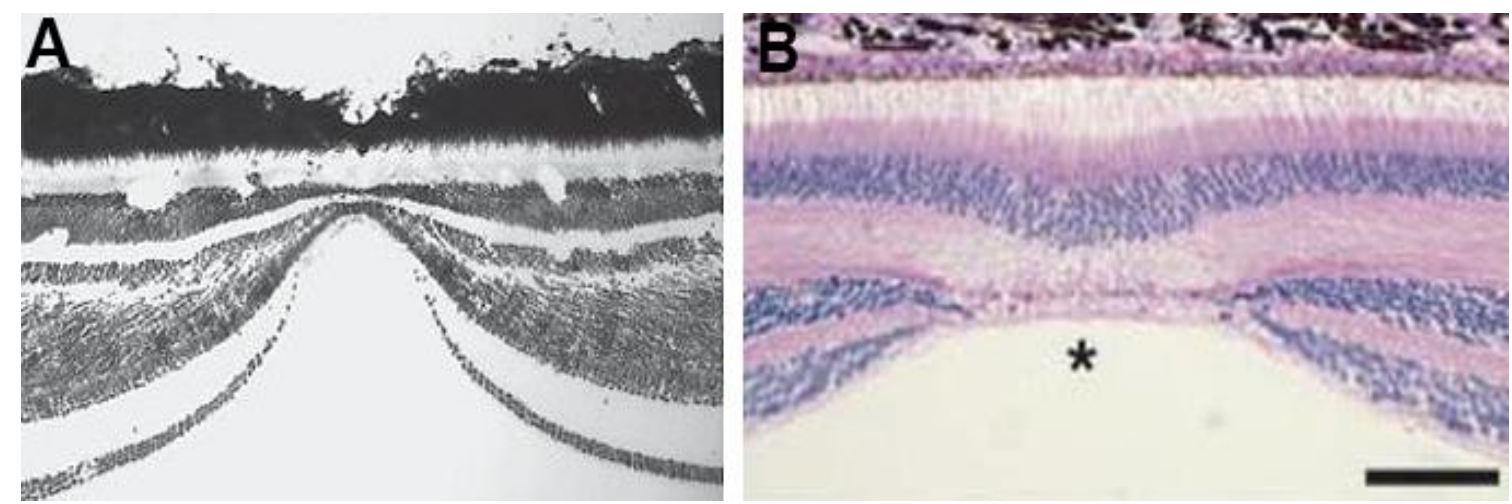

Figura 15. A. Fóvea convexiclivate de ave Pitangus sulphuratus (Coimbra et al., 2006). B. Fóvea concaviclivate (*) de primata Macaca mulata (Collin 2008).

\section{Resolução espacial}

Variações do poder de resolução espacial também refletem diferenças ecológicas entre as espécies, e são limitadas pelas características de difração e aberração óptica do olho, pela densidade de fotorreceptores e de células ganglionares, e por variáveis como erro de refração, iluminação do ambiente e contraste (Smith \& Atchison, 1997). Lisney 
\& Collin (2008) analisaram retinas de diversas espécies de elasmobrânquios (tubarões e raias) e observaram que espécies com um poder de resolução mais baixo tendem a ser relativamente menos ativas e se alimentam de invertebrados bentônicos e de pequenos peixes, enquanto espécies mais ativas, predadoras que geralmente se alimentam de presas maiores, possuem um poder de resolução maior.

As células ganglionares transmitem a informação visual da retina para os centros superiores. Estas células são em média maiores que os outros neurônios da retina e têm axônios mielinizados, com diâmetros largos, capazes de transmitir o potencial de ação para as áreas recipientes do cérebro, a muitos milímetros ou centímetros de distância da retina. O nervo óptico contém todos os axônios das células ganglionares, e as informações transmitidas por ele passam para canais de processamento no cérebro. Desta forma, uma vez que as células ganglionares transmitem as mensagens elétricas relacionadas ao sinal visual proveniente dos fotorreceptores e processado na camada nuclear interna (Ali \& Klyne, 1985), a sua densidade e distribuição pela retina são fatores importantes na determinação do poder de resolução visual do olho. Regiões da retina onde há aumento da densidade das células ganglionares apontam para especializações e maior acuidade visual destas áreas específicas. Desta forma, uma vez que a densidade de células ganglionares combinada ao tamanho do olho e do cristalino pode ser utilizada para determinar a resolução visual, esta abordagem tem sido utilizada para estimar a acuidade visual de muitas espécies (Hughes, 1971, 1975, 1977; Hokoç, 1975; Hokoç \& Oswaldo-Cruz, 1979; Silveira, 1985; Pettigrew et al., 1988; Silveira et al., 1989; Pettigrew \& Manger, 2008; Lisney \& Collin, 2008; Coimbra et al., 2009, 2013; Hart et al., 2012; Hauzman et al., 2014). 


\subsection{Serpentes: características do grupo e adaptações do sistema visual}

A classe Reptilia é dividida em duas subclasses: a primeira, Synapsida, deu origem aos Therapsidas e, posteriormente aos mamíferos e a segunda, Sauropsida, abrange os grupos Anapsida e Diapsida (Tudge, 2000). Sauropsidas modernos compreendem os Testudines (tartarugas e cágados), Sphenodontia (tuataras), Squamata (cobras, lagartos e anfisbenídeos) e o grupo Archosauromorpha, sendo este dividido em Crocodilia (crocodilos e jacarés) e as Aves (Tudge, 2000). A Ordem Squamata nomeada devido a característica mais evidente do grupo, a pele recoberta por escamas, é composta pelas serpentes (cerca de 3500 espécies), lagartos (cerca de 6000 espécies) e anfisbenídeos (cerca de 190 espécies) (números de espécies obtidos na base de dados http://reptile-database.org/) (Figura 16).

A infra-ordem Serpentes, caracterizada pelo alongamento do corpo, perda dos membros, ausência de pálpebras e de ouvido externo e a presença de língua bifurcada (Coates \& Ruta 2000), é subdividida em dois grupos principais. O grupo Scolecophidia (cobras cegas), com cerca de 470 espécies, é composto por serpentes fossoriais de pequeno porte, com olhos reduzidos e que se alimentam de pequenas presas, como cupins e formigas. O grupo Alethinophidia, por sua vez, é composto por uma maior diversidade de espécies, e é subdividido em Henophidia, grupo parafilético com cerca de 180 espécies, incluindo pítons e boas, e Caenophidia, com cerca de 2500 espécies (Vidal \& Hedges, 2004) (Figura 17). 


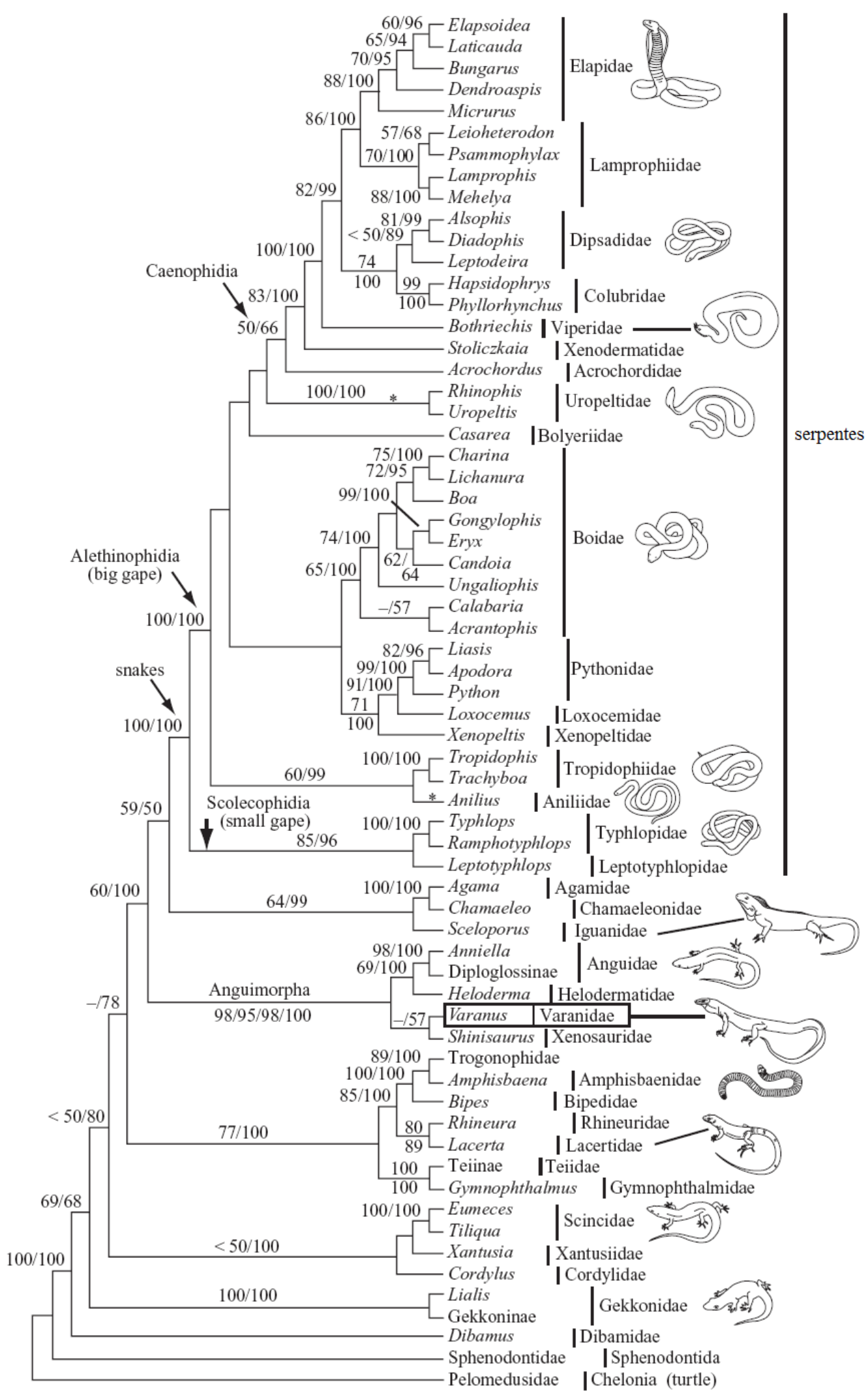

Figura 16. Relação filogenética entre serpentes, lagartos e anfisbenídeos, inferida a partir de sequências de DNA dos genes RAG1 e C-mos. Para os nós mais críticos, valores de quatro métodos de construção filogenética são mostrados na seguinte ordem: valores de suporte de bootstrap de máxima verossimilhança (MV), máxima parcimônia (MP), evolução mínima e probabilidade posterior Bayesiana. Para os outros nós são mostrados os valores de suporte de bootstrap de MP seguido das probabilidades posteriores Bayesianas (Vidal \& Hedges, 2004). 


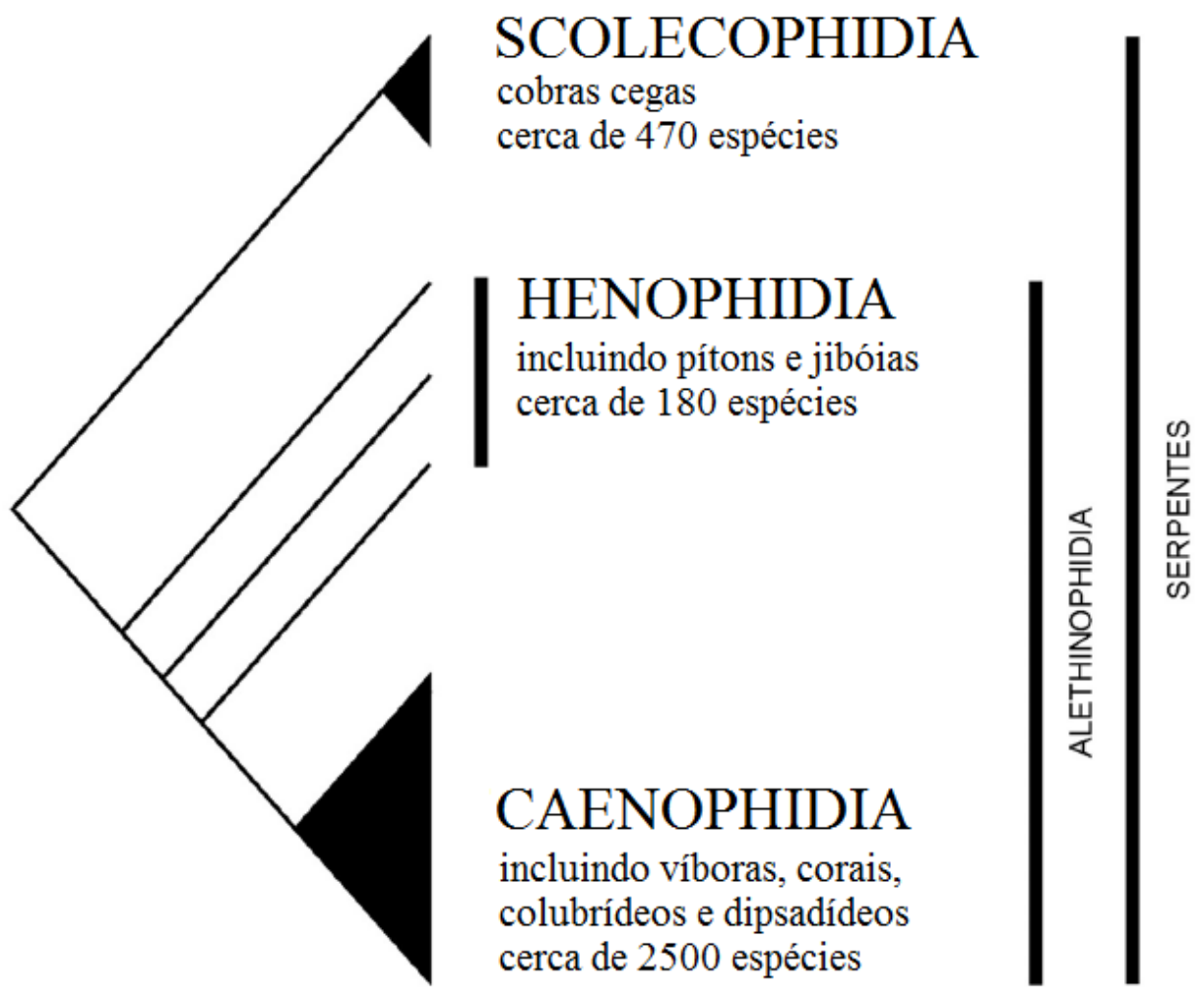

Figura 17. Cladograma esquemático mostrando a relação filogenética entre serpentes Scolecophidia (cobras cegas), Henophidia (pítons e boas) e Caenophidia (colubrídeos, dipsadideos, víboras) (modificado de Davies et al., 2009).

Serpentes do grupo Caenophidia são encontradas em praticamente todas as porções da biosfera, com exceção dos pólos, algumas ilhas e fundos oceânicos (Lillywhite \& Henderson, 1993). A grande diversidade deste grupo, com espécies adaptadas aos mais variados hábitats, pode ser explicada pela ocorrência de uma série de adaptações que favoreceram sua dispersão (Cadle, 1987; McDowell, 1987; Ford \& Burhard, 1993), e a especializações de seus sistemas sensoriais que evoluiram possibilitando a sua sobrevivência e radiação adaptativa. A Superfamília Colubroidea, importante grupo de serpentes Caenophidia, abrange famílias como a Dipsadidae e Colubridae, com espécies noturnas e/ou diurnas, terrestres, aquáticas ou semi-aquáticas. Serpentes terrestres podem ser classificadas como fossoriais, criptozóicas, terrícolas ou arborícolas, conforme o uso do substrato (Greene, 1997). 
O sistema visual das serpentes apresenta variações filogenéticas e ecológicas relacionadas aos seus hábitos e padrões de atividade (Underwood, 1967, 1970; Walls, 1942; Wong, 1989; Hart, et al., 2012; Hauzman, et al. 2014). Os diferentes hábitats ocupados pelas serpentes diferem na qualidade espectral da luz, o que deve influenciar nos padrões comportamentais relacionados à demanda pelo sistema visual (Ford \& Burghardt, 1993). Variações dos ítens alimentares e estratégias de caça (forrageamento ativo ou caça por espreita), empregadas pelas diferentes espécies de serpentes colubrídeas (Mushinsky, 1987) também apontam para adaptações do sistema visual.

A forma, o posicionamento e o tamanho relativo dos olhos são algumas das características morfológicas que indicam as variações na demanda pelo sistema visual. Serpentes de hábitos aquáticos possuem olhos e narinas posicionados mais dorsalmente na cabeça, como observado em espécies do gênero Helicops, o que facilita a visualização do ambiente fora da água, enquanto o corpo permanece submerso (Cadle \& Greene, 1993; Greene, 1997; Scartozzoni, 2005). Serpentes arborícolas, por sua vez, possuem grandes olhos laterais, e em alguns casos, como em Ahetulla, um acentuado afilamento rostral, que permite a visão binocular, característica de poucas espécies estritamente arborícolas (Lillywhite \& Henderson, 1993).

O olho dos répteis de forma geral tem estrutura bastante similar, mas o grupo das serpentes é uma exceção, uma vez que sua estrutura ocular difere nitidamente dos demais grupos desta classe (Walls, 1942). Sem considerar as famílias de cobras cegas (Typhlopidae e Leptotyphlopidae), com olho praticamente vestigial, o olho das demais serpentes tem estrutura muito padronizada. As variações mais importantes observadas entre as espécies estão relacionadas à estrutura da retina, formato da pupila e o tamanho relativo do cristalino, e estas diferenças são a base das mudanças do comportamento visual (Walls, 1942). 
As diferenças estruturais e funcionais entre os olhos dos lagartos (Figura $18 \mathrm{~A} \mathrm{e}$ C) e o das serpentes (Figura 18 B e D) indicam que os olhos das serpentes sofreram grandes mudanças a partir dos ancestrais lagartos (Walls, 1940). As principais diferenças envolvem estruturas diretamente associadas com a acomodação da imagem na retina. Nas serpentes a imagem é focalizada na retina por meio de uma pressão aplicada ao humor vítreo resultante da contração dos músculos periféricos da íris, forçando assim o cristalino, rígido e esférico, para a frente, dentro do globo ocular. $\mathrm{O}$ relaxamento destes músculos resulta na retração passiva da lente (Caprette et al., 2004). Este mecanismo difere do encontrado em lagartos, em que os músculos ciliares cercados pela coróide e ancorados a elementos ósseos fazem uma leve pressão na esclera, fazendo saltar a lente, flexível e plana (Walls, 1942). O mecanismo de acomodação da imagem observado em serpentes é comumente encontrado em vertebrados aquáticos, como peixes e anfíbios, que possuem uma lente esférica rígida que foca a imagem pelo movimento em direção à córnea (Walls, 1942; Fernald, 1990; Caprette et al., 2004). Outros animais aquáticos incluindo mamíferos e aves também possuem lentes mais esféricas do que seus parentes terrestres (Walls, 1942; Sivak, 1975; Supin et al., 2001). 


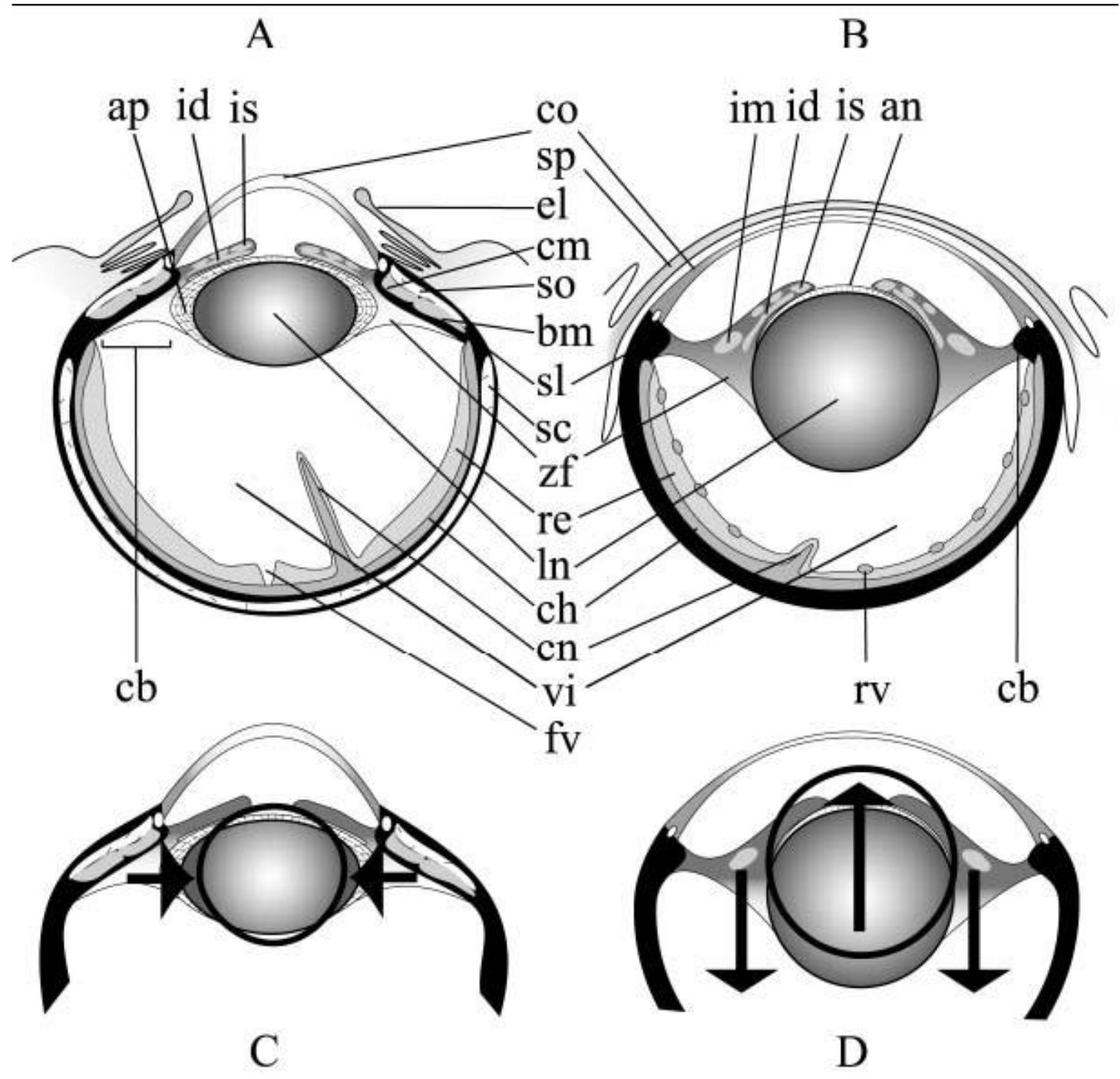

Figura 18. Anatomia funcional de olho de lagarto (A e C) e de serpente (B e D), ilustrando as principais diferenças entre os dois tipos. $\mathrm{C}$, lagarto foca a imagem na retina contraindo os grandes músculos ciliares (bm, $\mathrm{cm}$ ) ancorados aos ossículos da esclera (so), aplicando assim uma pressão na superfície lateral do cristalino (ln). D, serpentes focam a imagem na retina movendo o cristalino para frente, pelo aumento da pressão no vítreo (vi), devido à contração de músculos periféricos da íris (im). Abreviações: an, via anterior; bm, músculo ciliar de Brücke; cb, corpo ciliar; ch, coróide; cm, músculo ciliar de Crompton; cn, cônus papilar; co, córnea; el, pálpebra; fv, fóvea; id, músculo dilatador da íris; is, músculo do esfincter da íris; ln, lente; re, retina; sc, cartilagem da esclera; sl, esclera; sp, espectáculo; vi, humo vítreo; zf, fibras zonulares (Caprette et al., 2004).

\subsubsection{A retina de serpentes}

\section{Diversidade morfológica dos fotorreceptores}

Dependendo dos hábitos e da filogenia das espécies de serpentes, diferentes padrões de retinas podem ser observados, quanto aos tipos de fotorreceptores presentes. A diversidade morfológica de fotorreceptores na retina de serpentes foi descrita em 
alguns estudos (Walls, 1942; Underwood, 1967, 1970; Wong, 1989; Silman et al., 1997, 1999, 2001; Hart et al., 2012; Hauzman et al., 2014). Em serpentes Scolecophidia apenas bastonetes foram observados (Underwood, 1967), enquanto bastonetes e cones são encontrados em inúmeras espécies noturnas de diferentes famílias de serpentes Henophidia ("basais") e Caenophidia (“avançadas") (Walls, 1942; Underwood, 1967, 1970; Sillman et al., 1999, 2001). Serpentes Caenophidias diurnas, por sua vez, apresentam retinas com apenas cones (Walls, 1942; Underwood, 1967, 1970; Wong, 1989; Sillman et al., 1997; Hart et al., 2012; Hauzman et al., 2014).

No grupo Henophidia, as retinas apresentam predominância de bastonetes, que compõem cerca de $90 \%$ da população de fotorreceptores, e duas classes de cones, um cone simples grande e um cone simples pequeno (Sillman et al., 1999; 2001). Dentre os colubrídeos, Walls (1942) observou três tipos de cones, um cone simples grande, um cone simples pequeno e um cone duplo, cuja morfologia única no grupo dos ofídios não tem homologia com cones duplos de outros vertebrados (Walls, 1942). Cones duplos estão presentes em retinas de diversos grupos de vertebrados, e sua morfologia é altamente variável. As duas partes destes cones podem ser idênticas e bem fundidas (cones duplos pareados ou gêmeos) ou podem ter forma significativamente diferente (cones duplos assimétricos). Neste caso a porção maior do cone duplo é chamada de membro principal e a menor de membro acessório (Walls, 1942; Underwood, 1970; Bowmaker, 1991; Kolb et al., 2001). Cones duplos assimétricos foram observados em retinas de diferentes espécies de serpentes Caenophidia diurnas (Underwood, 1967, 1970; Walls, 1942; Wong, 1989; Sillman et al., 1997; Hart et al., 2012; Hauzman et al., 2014) (Figura 19).

A ausência de bastonetes em retinas de serpentes diurnas foi relatada para algumas espécies: Thamnophis sirtalis e T. proximus (Wong, 1989; Sillman et al., 1997; 
Yang, 2010), Philodryas olfersii e P. patagoninensis (Hauzman et al., 2014), e serpentes marinhas da família Hidrophiidae, Acalyptophis peronii e Lapemis curtus (Hart et al., 2012). Nestas espécies, quatro classes morfológicas de cones foram diferenciadas: uma classe de cones duplos e três classes de cones simples: um cone simples grande e dois grupos de cones simples pequenos (Sillman et al., 1997; Hart et al., 2012; Hauzman et al., 2014).

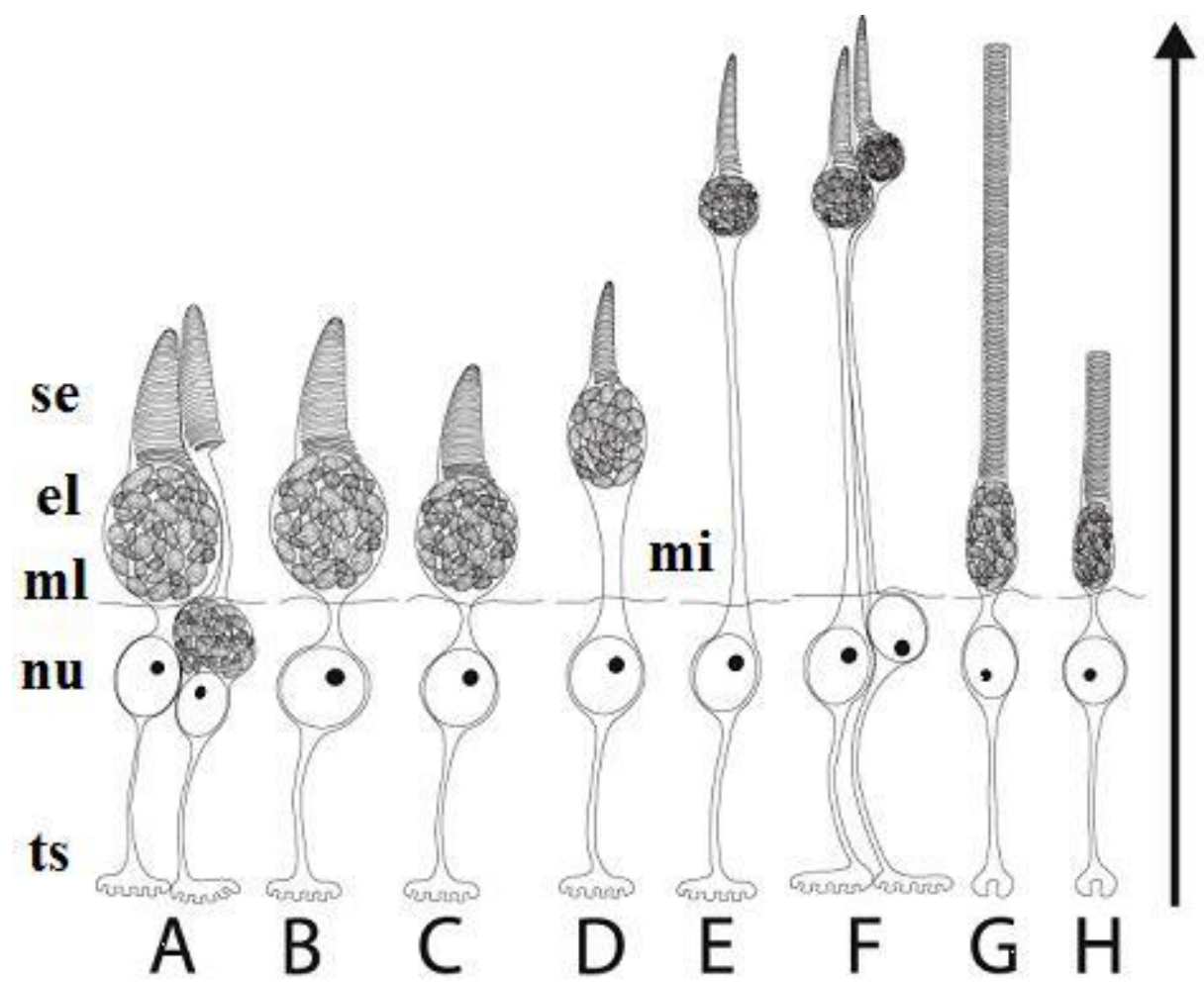

Figura 19. Representação morfológica de fotorreceptores de serpentes: (A) cones duplos, (B) cones simples grandes, (C) cones simples pequenos, (D) cones simples com mióide grande, (E) cones simples pequenos com mióide extremamente longo, (F) cone duplo com mióide extremamente longo, $(\mathrm{G})$ bastonete longo e $(\mathrm{H})$ bastonete curto. Abreviações: se, segmento externo; el, elipsóide; ml, membrana limitante; nu, núcleo; ts, terminal sináptico; mi, mióide. A seta representa a direção da luz pela retina (modificado de Caprette, 2005).

Outra característica marcante encontrada em alguns dos fotorreceptores de serpentes é a presença de microgotículas de óleo, distintas das gotículas de óleos encontradas em outros grupos de vertebrados, como peixes pulmonados, anfíbios, aves, répteis e mamíferos monotremados (ornitorrincos e équidnas) (Walls, 1942; Robinson, 1994) (Figura 20). Nestes grupos, as gotículas de óleo encontradas entre o segmento 
interno e externo de alguns dos cones, podem ser transparentes ou coloridas, e atuam como filtros que bloqueiam a luz na faixa espectral de menor comprimento de onda. Gotículas de óleo coloridas são mais desenvolvidas em aves diurnas e em alguns répteis e têm um papel importante na visão de cores destes animais (Takase et al., 1998; Hart et al., 2000; Kolb et al., 2001; Loew et al., 2002; Vorobyev, 2003). As microgotículas de serpentes foram observadas no elipsóide do membro principal de cones duplos e dos cones simples grandes de serpentes diurnas (Thamnophis sirtalis e T. proximus). Com cerca de 0.1-0.15 $\mu \mathrm{m}$ de diâmetro e com alto índice de refração, foi sugerido que estas estruturas, atuando em conjunto, podem funcionar como filtros de luz, em substituição a uma única gota de óleo (Wong, 1989; Yang, 2010). Walls (1942) sugere que a perda das gotículas de óleo em diversas espécies pode ter sido ocasionada pela mudança de padrões de atividade diurna para noturna, e uma vez perdida, esta complexa estrutura dificilmente poderia ser readquirida. Desta forma, as microgotículas observadas em serpentes diurnas seriam uma característica exclusiva adquirida neste grupo.

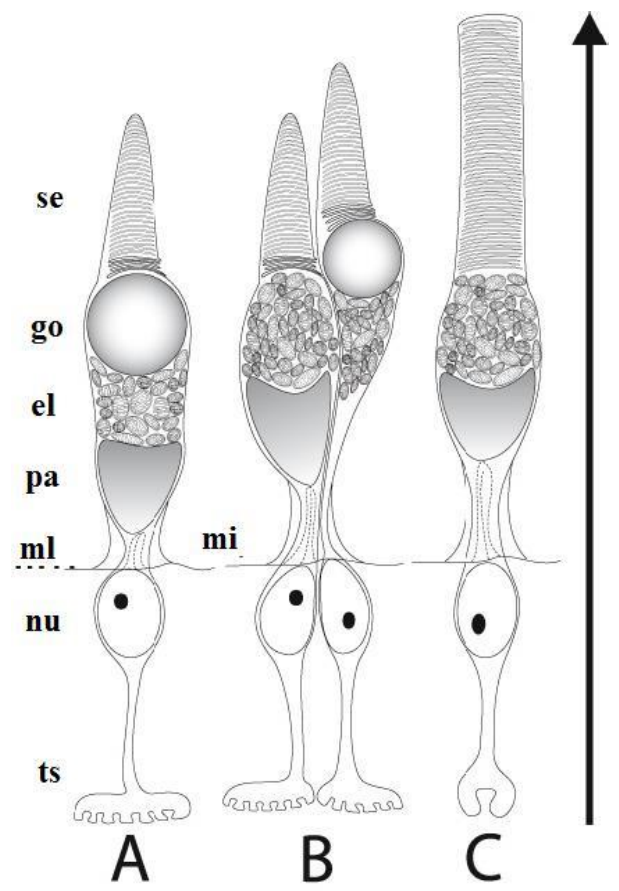

Figura 20. Representação de corte transversal de fotorreceptores da tartaruga Trachemys scripta. (A) cone simples, (B) cone duplo, (C) bastonete. Abreviações: se, segmento externo; go, gotícula de óleo; el, elipsóide; pa, parabolóide; ml, membrana limitante; mi, mióide; nu, núcleo; ts, terminal sináptico. A seta indica a direção da passagem da luz pela retina (Caprette, 2005). 


\section{Sensibilidade espectral e caracterização dos pigmentos visuais de serpentes}

A sensibilidade espectral dos fotorreceptores foi medida em espécies de serpentes das famílias Boidae, Colubridae, Viperidae e Hydrophiidae (Govardovskii \& Chkheidze, 1989; Jacobs et al., 1992;. Sillman et al., 1997, 1999, 2001; Davies et al., 2009; Hart et al., 2012). Boídeos noturnos apresentaram predominância de bastonetes, com pico de sensibilidade espectral $\lambda_{\max }$ de $494 \mathrm{~nm}$, e dois tipos de cones com sensibilidade em comprimentos de onda longos, na faixa do verde-vermelho, com $\lambda_{\max }$ de $551 \mathrm{~nm}$ e curtos, na faixa do ultravioleta, com $\lambda_{\max }$ de $360 \mathrm{~nm}$ (Sillman et al., 1999; 2001). Na serpente Caenophidia diurna T. sirtalis, três picos de absorção foram distinguidos (Sillman et al., 1997): um pigmento visual maximamente sensível a comprimentos de onda longos (LWS) com $\lambda_{\max }$ de $554 \mathrm{~nm}$, nos cones grandes simples e nos membros principais e acessórios dos cones duplos, um pigmento visual maximamente sensível a comprimentos de onda curtos (SWS), com $\lambda_{\max }$ de $360 \mathrm{~nm}$, nos cones simples pequenos, e um pigmento maximamente sensível a comprimentos de onda médios (MWS), de $482 \mathrm{~nm}$, na segunda classe de cones simples pequenos. Em retinas de serpentes marinhas Hydrophiidae, cones duplos e cones simples grandes também contêm pigmentos visuais LWS (555-559 nm). Cones simples pequenos têm pigmentos SWS (428-430 nm), e a segunda classe de cones simples pequenos contêm um pigmento MWS (496 nm) (Hart et al., 2012).

Os pigmentos visuais foram geneticamente classificados em apenas duas espécies de serpentes Henophidia, Xenopeltis unicolor e Python regius, e pertencem à classe de bastonetes RH1 e de cones SWS1 e LWS (Davies et al., 2009). Desta forma, estas serpentes mantiveram duas das quatro classes de pigmentos de cones dos vertebrados ancestrais, um possível reflexo de sua natureza noturna/crepuscular e fossorial (Figura 21) (Davies et al., 2009). 


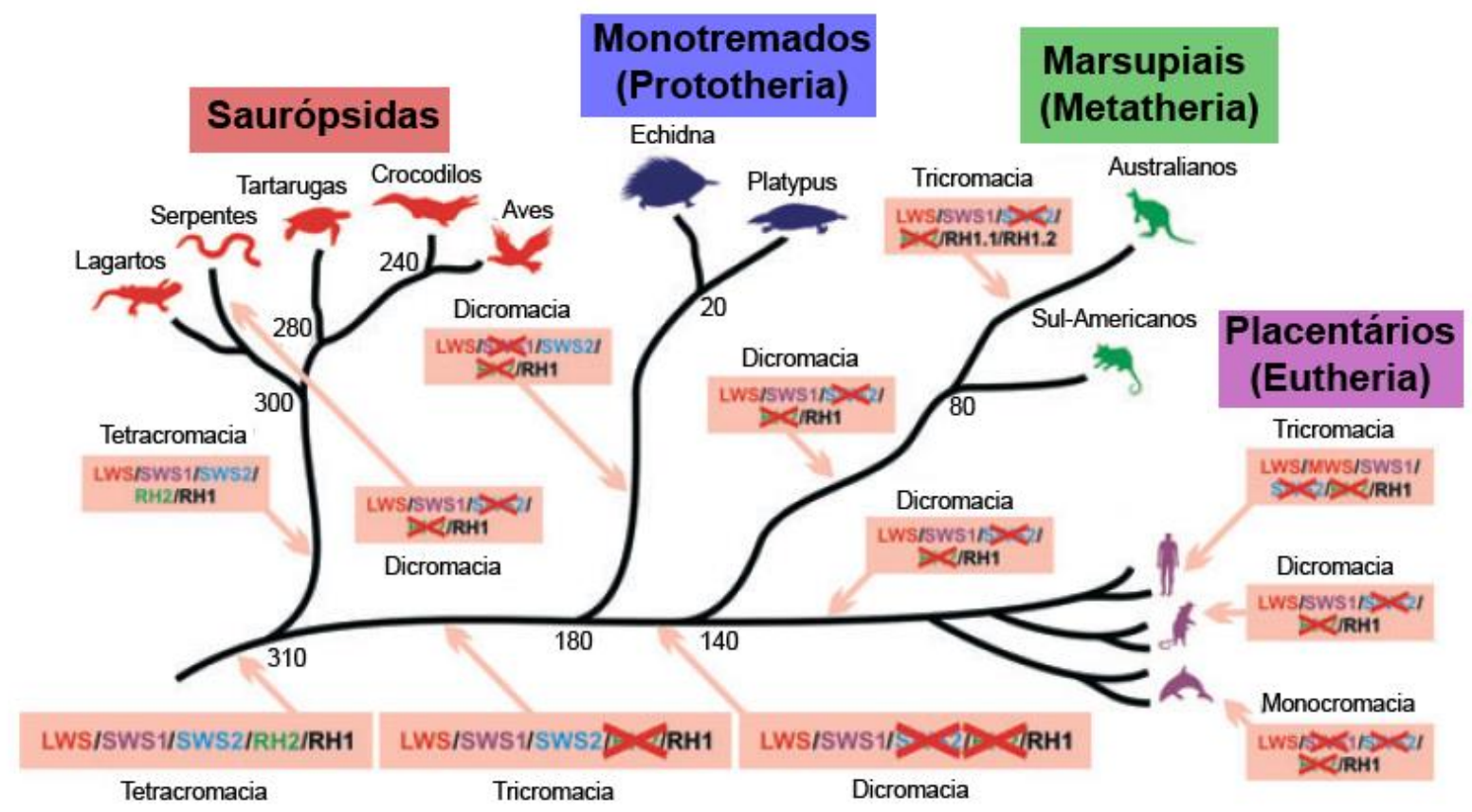

Figura 21. Cladograma sumário mostrando a progressão evolutiva de cada classe de opsina, mediada pela conservação genética, perda e duplicação, dentro dos principais ramos da radiação dos craniatas. No grupo das serpentes os pigmentos SWS2 e RH2 foram perdidos. Datas aproximadas de especiação estão mostradas em milhões de anos (modificado de Davies et al., 2012).

\section{Teoria da transmutação}

A variabilidade morfológica de fotorreceptores de retinas de répteis atuais, levou Walls (1934) a propor que cones e bastonetes poderiam ser interconversíveis, em um processo que ele denominou de "transmutação". De acordo com esta teoria da transmutação, retinas duplex (com cones e bastonetes) dos répteis atuais se originaram a partir de retinas de apenas cones e da conversão destas células para bastonetes. Em sua formulação teórica, Walls $(1934,1942)$ citou os fotorreceptores de serpentes e de geckos como exemplo. Em geckos, os fotorreceptores sensíveis a comprimentos de onda médios, descritos como do tipo bastonete com base na morfologia e sensibilidade à luz, expressam um gene de "cone" RH2, o que corrobora a teoria da transmutação (Yokoyama \& Blow, 2001). Walls $(1934,1942)$ sugere que retinas de colubrídeos noturnos, com cones e bastonetes, provém do padrão de apenas cones de colubrídeos diurnos, no qual bastonetes contém pigmento visual de cone, assim como observado em 
geckos. Entretanto, Davies et al. (2009) sugerem que a perda do pigmento RH2 ocorreu no ancestral de todas as serpentes atuais, e que o padrão de apenas cones de colubrídeos diurnos se originou a partir de retinas duplex de serpentes ancestrais.

Considerando a ausência de bastonetes e a presença dos diferentes pigmentos visuais observados no colubrídeo diurno T. sirtalis (Sillman et al., 1997), Davies et al. (2009) sugerem que o cone sensível aos comprimentos de onda médios presente na retina desta espécie deve conter um pigmento RH1 "de bastonete", indicando uma transmutação inversa, de bastonetes para cones. De fato Yang (2010), demostrou que a transducina específica de bastonete é expressa em alguns fotorreceptores de $T$. proximus e que a expressão in vitro do gene RH1 desta espécie gera uma rodopsina funcional com $\lambda_{\max }$ de $485 \mathrm{~nm}$, que corresponde às medidas de microespectrofotometria para alguns cones simples pequenos de retina de serpentes diurnas (Sillman et al., 1997). O fato sugere que estes cones podem ter evoluido a partir de bastonetes, adquirindo posteriormente a morfologia de cone como adaptação à vida diurna.

Estudos moleculares das classes de pigmentos visuais de serpentes Caenophidia são necessários para confirmar esta hipótese e esclarecer as bases da evolução de opsinas neste diverso grupo, bem como complementar dados acerca da origem destes animais quanto aos padrões de atividade e ecologia visual de espécies ancestrais.

\section{Especializações da retina de serpentes: distribuição de células e resolução espacial}

Além dos diferentes tipos de fotorreceptores e pigmentos visuais expressos em retinas de vertebrados, os estudos comparativos demonstraram que a distribuição e a densidade de neurônios da retina são variáveis entre espécies e que a topografia da retina parece estar correlacionada com o hábitat ou estilo de vida das espécies (Hughes, 1971, 1977; Silveira, 1985; Silveira et al., 1989; Collin, 1999, 2008). Diversos estudos 
têm utilizado o valor do espaçamento entre as células ganglionares nas áreas de maior densidade, em combinação com a distância focal do olho, para estimar o poder de resolução espacial máxima em diversas espécies de vertebrados (Hokoç, 1975; Silveira, 1985; Silveira et al., 1989; Pettigrew et al., 1988; Collin \& Pettigrew, 1989; Pettigrew \& Manger, 2008; Hart et al., 2012; Coimbra et al., 2013). Até o momento, a distribuição de neurônios em retinas de serpentes só foi avaliada em poucas espécies: a serpente terrestre T. sirtalis (Wong, 1989), três espécies de serpentes marinhas, Lapemis curtus, Aipysurus laevis e Disteira major (Hart et al., 2012), e duas serpentes terrestres, Philodryas olfersii e P. patagoniensis (Hauzman et al., 2014).

Wong (1989) descreveu a distribuição do tipo faixa visual para cones e células da camada de células ganglionares, em retinas de serpentes $T$. sirtalis. Em estudo comparativo de retinas de serpentes do gênero Philodryas, Hauzman et al. (2014) observaram variações topográficas da retina, com diferentes regiões de especialização que apontam para adaptações ao uso de substrato em espécies filogeneticamente próximas. A serpente arborícola $P$. olfersii apresentou faixa horizontal e duas discretas areae centrales anisotrópicas nas regiões central e temporal da retina. A distribuição de células observada nesta espécie deve ter importância para a locomoção e o forrageamento no extrato arbóreo. A espécie terrestre P. patagoniensis apresentou area centralis anisotrópica no quadrante ventro-rostral da retina, favorecendo o campo visual superior (Figura 22). Este tipo de regionalização deve ter importância para serpentes terrestres, permitindo a observação da aproximação de predadores vindos de cima. Em retinas de serpentes marinhas da família Hidrophiidae, Hart et al. (2012), observaram estria horizontal nas espécies Lapemis curtus, Disteira major e Aipysurus laevis, com discretas areae nos quadrantes temporal e nasal. As espécies L. curtus e D. major 
também apresentaram area na região ventral da retina, que deve refletir diferenças no uso de hábitat comparado com A. laevis.
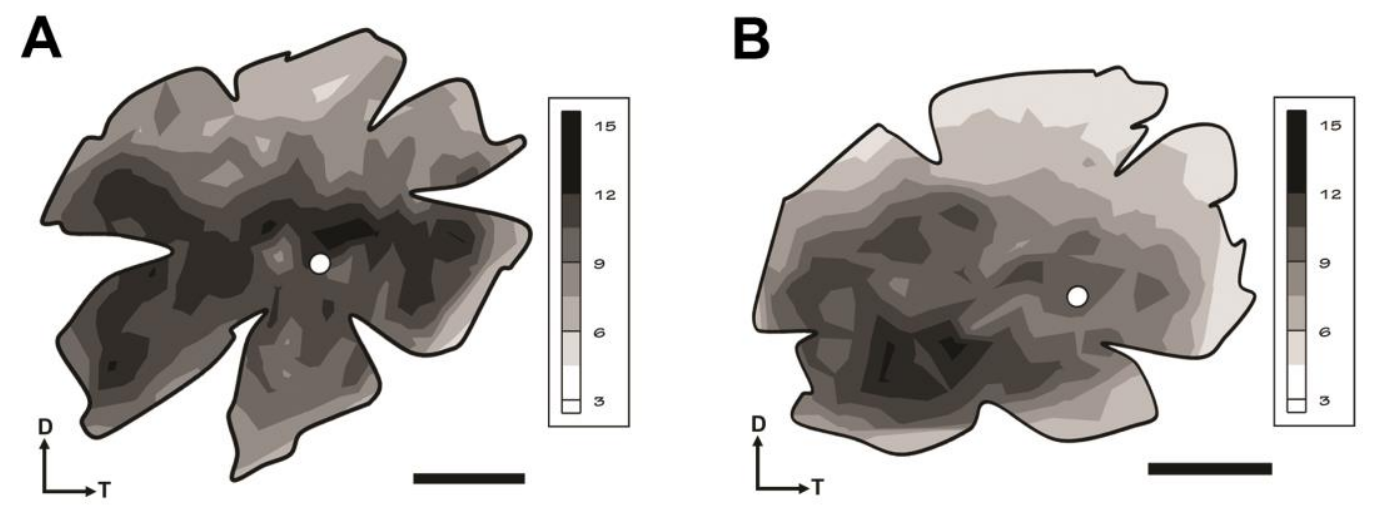

Figura 22. Mapas topográficos de fotorreceptores da serpente arborícola $P$. olfersii, com faixa horizontal, e da terrícola $P$. patagoniensis, com area centralis ventro-rostral. D, dorsal; T, temporal. O ponto branco representa o nervo óptico. Escala $2 \mathrm{~mm}$ (Hauzman et al., 2014).

Os limites superiores do poder de resolução espacial, estimados com base no pico de densidade de células ganglionares e na distância focal do olho, foram de 2,3 cpg em T. sirtalis (Wong, 1989; Hart et al., 2012) e variaram entre 2,3 e 2,8 cpg em $P$. olfersii e P. patagomensis (Hauzman et al., 2014). Em serpentes marinhas os valores variaram entre 1,1 e 2,3 cpg (Hart et al., 2012). Os menores valores obtidos para serpentes marinhas foram atribuídos ao tamanho reduzido do olho e às diferenças nas propriedades fóticas da água, comparadas ao ar. Mesmo nos hábitats de águas mais claras a luz sofre dispersão, o que resulta em uma maior redução da qualidade da imagem com a distância, quando comparado à visão no ar (Hauzman et al., 2014).

Em suma, a variabilidade de espécies e de uso de ambiente pelas serpentes aponta para inúmeras adaptações de seu sistema visual, no que diz respeito aos tipos de fotorreceptores, evolução dos pigmentos visuais, sensibilidade espectral das opsinas, e as especializações das retinas e regiões de aumento de densidade celular. Estudos acerca das características e adaptações do sistema visual de serpentes são extremamente escassos, quando considerado o grande número de espécies e a diversidade deste fascinante grupo de vertebrados. 


\section{JUSTIFICATIVA}

O grupo das serpentes apresenta grande diversidade morfológica e inúmeras adaptações ecológicas. Seu posicionamento filogenético dentro da ordem Squamata ainda é controverso, assim como sua origem com relação aos hábitos e ecologia do ancestral comum. O grande número de espécies e radiações adaptativas de serpentes Caenophidia implica em dificuldades de estabelecer relações filogenéticas, sendo necessária a ampliação de estudos morfológicos, ecológicos e comportamentais.

Os tipos de fotorreceptores e a densidade e topografia de neurônios da retina podem variar de acordo com a demanda dos animais pelo sistema visual, da mesma forma que o comportamento de uma espécie pode ser moldado de acordo com as estruturas do sistema visual. Estas características trazem informações valiosas sobre a história natural das espécies. Na literatura alguns estudos descrevem a morfologia dos fotorreceptores de retinas de serpentes (Walls, 1942; Underwood, 1967, 1970, 1971; Sillman et al., 1997, 1999, 2001; Caprette et al., 2004; Yang, 2010; Hart et al., 2012; Hauzman et al., 2014). Trabalhos utilizando técnicas de microespectrofotometria avaliaram o espectro de absorbância de luz dos fotorreceptores de serpentes das famílias Boidae, Colubridae, Viperidae e Hydrophiidae (Govardovskii \& Chkheidze, 1989; Sillman et al., 1997, 1999, 2001; Hart et al., 2012). Sillman et al. (1997) forneceram as primeiras evidências de sensibilidade à luz ultravioleta em serpentes da família Boidae. Wong (1989) correlaciona as distribuições de células ganglionares e de fotorreceptores em retinas da serpente colubrídea Thamnophis sirtalis e apenas dois trabalhos correlacionam as áreas de maior densidade de neurônios com adaptações ao uso de substrato, em serpentes do gênero Philodryas (Hauzman et al., 2014) e em serpentes marinhas (Hart et al., 2012). A acuidade visual foi descrita com base em registros de 
respostas telencefálicas provocadas (Baker et al., 2007) e estimada a partir da densidade de células da CCG (Hart et al., 2012; Hauzman et al., 2014). Em estudo com genética de opsinas, Davies et al. (2009) determinaram os diferentes grupos de pigmentos visuais de serpentes Henophidia.

Com base na sua diversidade ecológica, serpentes Caenophidia representam um bom modelo para testar hipóteses de correlação entre especializações da retina e ecologia comportamental. Estudos morfológicos de retinas de 20 diferentes espécies de serpentes (Tabelas 1 e 2, em Material e Métodos) foram realizados para comparação dos tipos, densidade e distribuição dos fotorreceptores e de células da CCG e os resultados obtidos foram correlacionados com aspectos ecológicos, comportamentais e filogenéticos das espécies. O estudo de densidade e topografia de neurônios tem como base trabalhos anteriores realizados no Laboratório de Psicofisiologia Sensorial do Instituto de Psicologia, USP, onde foram quantificados os diferentes tipos de fotorreceptores em retinas de tartarugas (Grötzner et al., 2004, 2005; Grötzner, 2005) e os fotorreceptores e células da CCG de retinas de serpentes (Hauzman et al., 2014).

Para determinar as bases moleculares da sensibilidade espectral dos fotorreceptores de serpentes Caenophidia, os genes das três classes de pigmentos visuais expressas em retinas de serpentes Henophidia, RH1, SWS1 e LWS, foram amplificados e sequenciados em 17 espécies de serpentes Caenophidia e duas espécies de serpentes Henophidia (Tabela 2, em Material e Métodos). 


\section{OBJETIVOS}

- Determinar as bases moleculares da sensibilidade espectral de fotorreceptores de serpentes Caenophidia, investigando os genes que expressam as diferentes classes de pigmentos visuais em espécies das famílias Colubridae e Dipsadidae, por meio da amplificação e sequenciamento dos genes de opsinas expressos nas retinas.

- Estabelecer as relações filogenéticas entre os grupos de opsinas expressos nas retinas das diferentes espécies de serpentes.

- Comparar os tipos de fotorreceptores em retinas de serpentes diurnas e noturnas, bem como a densidade e distribuição dos fotorreceptores de retinas de diferentes espécies de serpentes Caenophidia, com técnicas de imunohistoquímica de opsinas.

- Comparar a densidade e distribuição de células da camada de células ganglionares (CCG) de retinas de diferentes espécies de serpentes Caenophidia, com técnica de Nissl.

- Verificar possíveis correlações entre a distribuição de fotorreceptores e de células da CCG nas retinas e a presença de especializações (area centralis ou faixa visual).

- Estimar o poder de resolução espacial do olho de cada espécie, com base no pico de densidade de células da CCG e na distância focal.

- Correlacionar os resultados de densidade, topografia e resolução espacial com características ecológicas e comportamentais das serpentes e possíveis adaptações ao uso de substrato. 


\section{MATERIAL E MÉTODOS}

\subsection{Serpentes: descrição das espécies e procedimentos com os animais}

Retinas de 26 diferentes espécies de serpentes foram obtidas para estudos morfológicos da retina e estudos genéticos, totalizando 105 animais. Para as análises morfológicas, retinas de 21 diferentes espécies de serpentes Caenophidia, das famílias Colubridae e Dipsadidae, foram analisadas. As espécies foram selecionadas de acordo com a filogenia e caracteres ecológicos e comportamentais, como padrões de atividade (hábitos diurnos, noturnos ou crepusculares), uso de substrato (terrícola, arborícola, fossorial ou aquático) e tipos de presas ingeridas (Tabela 1). Para os estudos de genética de opsinas, foram analisadas retinas de 19 espécies (Tabela 2), incluindo duas espécies de serpentes do grupo Henophidia, Boa constrictor e Epicrates crassus para compor o grupo externo nas análises filogenéticas. A tabela 2 descreve o número de indivíduos analisados por espécie, que variou conforme a chegada e disponibilidade dos espécimes recebidos no Instituto Butantan, São Paulo.

As serpentes capturadas e entregues por fornecedores do Instituto Butantan foram obtidas junto à Recepção de Serpentes do Laboratório de Herpetologia. Os animais foram acondicionados em caixas plásticas, com água, em ambiente próprio para sua manutenção, no Biotério da Sessão de Venenos do Laboratório de Herpetologia, ou na Recepção de Serpentes do Instituto. A eutanásia foi feita com dose letal do anestésico Thionembutal (princípio ativo tiobarbiturato etil sódico, dosagem $30 \mathrm{mg} / \mathrm{kg}$ ) e em seguida os animais foram mantidos por duas horas no escuro. Após a eutanásia foram tomadas as medidas de massa (m) e comprimento total (CT) e prontamente iniciados os procedimentos de enucleação dos olhos e dissecção das retinas. 
Tabela 1. Espécies de serpentes utilizadas nos estudos comparativos do sistema visual (genética de opsinas e morfologia da retina).

\begin{tabular}{|c|c|c|c|c|c|c|c|c|}
\hline Família & Subfamília & Tribo & Gênero & Espécie & Atividade & Substrato & Dieta & Referências \\
\hline \multirow[b]{2}{*}{ Colubridae } & & & Chironius & bicarinatus & $\mathrm{D}$ & S-AR & An & Sazima \& Haddad, 1992; Hartmann et al., 2009 \\
\hline & & & Spilotes & pullatus & $\mathrm{D}$ & AR & $\mathrm{Ma} ; \mathrm{Av}$ & $\begin{array}{l}\text { Marques \& Sazima, 2004; Hartmann et al., } \\
2009\end{array}$ \\
\hline \multirow{21}{*}{ Dipsadidae } & \multirow{8}{*}{ Dipsadinae } & & \multirow[b]{2}{*}{ Atractus } & pantostictus & \multirow[b]{2}{*}{$\mathrm{N}$} & \multirow[b]{2}{*}{ FS } & \multirow[b]{2}{*}{$\mathrm{Al}$} & Peters \& Orejas-Miranda, 1970; Martins \& \\
\hline & & & & reticulatus & & & & $\begin{array}{c}\text { Oliveira, 1993, 1999; Marques et al., 2004; } \\
\text { Hartmann et al., } 2009 .\end{array}$ \\
\hline & & & \multirow{4}{*}{ Dipsas } & albifrons & \multirow{4}{*}{$\mathrm{N}$} & \multirow{4}{*}{$\mathrm{AR}$} & \multirow{4}{*}{ Mo } & \\
\hline & & & & bucephala & & & & Sazima, 1989; Martins \& Oliveira, 1999; \\
\hline & & & & indica & & & & Hartmann et al., 2009 \\
\hline & & & & & & & & \\
\hline & & & \multirow{2}{*}{ Sibynomorphus } & mikanii & $\mathrm{N}$ & $\mathrm{TE}$ & Mo & Oliveira, 2001; Sawaya et al., 2008 \\
\hline & & & & neuwiedi & $\mathrm{N}$ & $\mathrm{AR} / \mathrm{TE}$ & Mo & Oliveira 2001, Marques \& Sazima 2004 \\
\hline & \multirow{13}{*}{ Xenodontinae } & \multirow{3}{*}{ Xenodontini } & \multirow{3}{*}{ Erythrolamprus } & aesculapii & $\mathrm{C}$ & TE & $\mathrm{Se}$ & Marques et al., 2009 \\
\hline & & & & miliaris & $\mathrm{D}$ & S-AQ & $\begin{array}{l}\text { Gn }(\mathrm{An} ; \mathrm{Pe} \\
\mathrm{La} ; \mathrm{Ab})\end{array}$ & $\begin{array}{c}\text { Sazima \& Haddad, 1992; Marques \& Souza, } \\
\text { 1993; Machado et al., 1998; Marques \& } \\
\text { Sazima, 2004; Hartmann et al., } 2009\end{array}$ \\
\hline & & & & poecilogyrus & $\mathrm{D} / \mathrm{N}$ & $\mathrm{TE}$ & $\mathrm{La} ; \mathrm{An}$ & $\begin{array}{l}\text { Sawaya et al., 2008; Dixon \& Markezich, 1992; } \\
\text { Strüssmann \& Sazima, } 1993\end{array}$ \\
\hline & & Pseudoboini & Oxyrhopus & $\begin{array}{c}\text { clathratus } \\
\text { guibei }\end{array}$ & $\mathrm{N}$ & $\mathrm{TE}$ & $\mathrm{Ma} ; \mathrm{La}$ & Hartman et al., 2009 \\
\hline & & Hydropsini & Helicops & modestus & $\mathrm{D} / \mathrm{N}$ & AQ & Pe; An & $\begin{array}{c}\text { Dixon \& Soini, 1977; Hartman et al., 2009; } \\
\text { Sawaya et al., } 2008\end{array}$ \\
\hline & & \multirow{3}{*}{ Echinantherini } & \multirow{2}{*}{ Echinantera } & cephalostriata & $\mathrm{D} / \mathrm{N}$ & TE & An & Marques et al., 2001 \\
\hline & & & & undulata & $\mathrm{D}$ & TE & An & Marques et al., 2001 \\
\hline & & & Taeniophallus & persimilis & $\mathrm{D}$ & $\mathrm{TE}$ & An; La & Hartman et al., 2009 \\
\hline & & Philodryadini & Philodryas & patagoniensis & $\mathrm{D}$ & TE & An; Ma & Marques et al., 2001 \\
\hline & & \multirow{4}{*}{ Tachymenini } & Tomodon & dorsatus & $\mathrm{D}$ & TE & Mo & Marques et al., 2009 \\
\hline & & & \multirow{3}{*}{ Thamnodynastes } & hypoconia & $\mathrm{N}$ & S-AR/TE & An; La & Hartman et al., 2009; Sawaya et al., 2008 \\
\hline & & & & natererii & $\mathrm{N} / \mathrm{C}$ & S-AR/TE & An & $\begin{array}{l}\text { Marques \& Sazima 2004; Hartman et al., 2009; } \\
\text { Strüssmann } 1992\end{array}$ \\
\hline & & & & strigatus & $\mathrm{N}$ & S-AR & An; Ma; La & $\begin{array}{c}\text { Bernarde et al. 2000; Hartman et al., 2009; } \\
\text { Marques et al. } 2004\end{array}$ \\
\hline
\end{tabular}

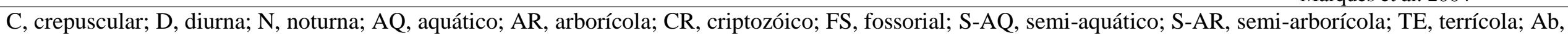
anfisbenídeos; Al, anelídeos; An, anuros; Av, aves; Gn, generalista; La, lagartos; Ma, mamíferos; Mo, molusco; Pe, peixes; Se, serpentes. 
Tabela 2. Espécies de serpentes e número de indivíduos obtidos para estudos de morfologia da retina e genética de opsinas.

\begin{tabular}{cccc}
\hline Espécies & $\begin{array}{c}\text { Total de serpentes } \\
\text { analisadas }\end{array}$ & $\begin{array}{c}\text { Morfologia da } \\
\text { retina }\end{array}$ & $\begin{array}{c}\text { Genética de } \\
\text { opsinas }\end{array}$ \\
\hline Atractus pantostictus & 4 & 4 & 0 \\
Atractus reticulatus & 4 & 3 & 1 \\
Boa constrictor & 1 & 0 & 1 \\
Chironius bicarinatus & 8 & 7 & 1 \\
Dipsas albifrons & 1 & 1 & 0 \\
Dipsas bucephala & 3 & 3 & 0 \\
Dipsas indica & 2 & 2 & 0 \\
Dipsas petersi & 2 & 1 & 1 \\
Echinantera cephalostriata & 1 & 0 & 1 \\
Echinantera undulata & 5 & 4 & 1 \\
Epicrates crassus & 1 & 0 & 1 \\
Erythrolamprus aesculapii & 8 & 7 & 1 \\
Erythrolamprus miliaris & 8 & 7 & 1 \\
Erythrolamprus poecilogyrus & 6 & 5 & 1 \\
Helicops modestus & 8 & 7 & 0 \\
Oxyrhopus clathratus & 1 & 1 & 1 \\
Oxyrhopus guibei & 7 & 6 & 1 \\
Philodryas patagoniensis & 1 & 0 & 1 \\
Sibynomorphus mikanii & 6 & 5 & 1 \\
Sibynomorphus neuwiedi & 8 & 7 & 1 \\
Spilotes pullatus & 3 & 2 & 1 \\
Taeniophallus persimilis & 1 & 0 & 0 \\
Thamnodynastes hypoconia & 2 & 1 & 0 \\
Thamnodynastes natererii & 1 & 1 & 19 \\
Thamnodynastes strigatus & 5 & 5 & \\
Tomodon dorsatus & 8 & $\mathbf{8 6}$ & 1 \\
\hline Total de indivíduos & $\mathbf{1 0 5}$ & & 1 \\
\hline
\end{tabular}

Os procedimentos com os animais estavam de acordo com os princípios éticos de manejo e experimentações com animais, estabelecidos pelo Colégio Brasileiro de Experimentação Animal (COBEA) e tiveram a aprovação das Comissões de Ética em Pesquisa com Animais do Instituto de Psicologia da Universidade de São Paulo, do Instituto Butantan e do Instituto Israelita de Ensino e Pesquisa do Hospital Albert Einstein, onde parte dos trabalhos de genética foram realizados (Anexos 1 a 3). Todos os animais utilizados foram previamente selecionados para inclusão na Coleção Herpetológica Alphonse Richard Hoge, do Instituto Butantan. O número de tombo e as medidas de cada espécime encontram-se no Anexo 4. 


\subsection{Genética de Opsinas}

\section{Isolamento de RNA mensageiro}

Após enucleação dos olhos as retinas foram dissecadas e preservadas em RNA Later (Ambion) a $4^{\circ} \mathrm{C}$. O RNA mensageiro (RNAm) foi extraído com o kit PUREGENE ${ }^{\circledR}$ Micro mRNA Purification (Gentra Systems, Minneapolis, Minnesota, EUA), conforme protocolo do fabricante.

\section{Síntese de DNA complementar}

Uma diluição de 1 em 10 de RNAm da retina foi preparada com 500 ng de primer oligo-dT (12-mer) e convertido para fita simples de DNA complementar (cDNA) usando a trancriptase reversa Superscript III (Life Technologies, Carlsbad, California, EUA), seguindo o protocolo do fabricante.

\section{Amplificação do cDNA por reação em cadeia da polimerase $(\mathrm{PCR})$ e sequenciamento}

A reação em cadeia de polimerase (PCR) foi realizada para amplificar a sequência de nucleotídeos que compõe o cDNA das opsinas expressas nas retinas das serpentes analisadas. Inicialmente foram utilizados conjuntos de primers específicos para serpentes, desenhados a partir das sequências das opsinas LWS, SWS1 e Rh1 de serpentes Henophidia, descritas por Davies et al. (2009) (número de acesso no Genebank: FJ497233 - FJ497238). Para cada transcrito foram desenhados dois pares de primers específicos: um forward (F1) no início da sequência e um reverse (R1) alinhado no meio da sequência, e um segundo primer forward (F2) na metade da sequência, utilizado em conjunto com o segundo primer reverse (R2), alinhado no final do gene expresso (Tabela 3 ). 
Tabela 3. Descrição dos primers squamata-específicos utilizados para amplificar genes de opsinas expressos em retinas de serpentes.

\begin{tabular}{c|ccl} 
Primer & Opsina & Temp annealing & Sequência de Nucleotídeos do Primer \\
\hline SquaLWSF1 & LWS & 59.5 & 5' ATGACAGAGGCCTGGAATGT 3' \\
SquaLWSF2 & LWS & 58.4 & 5' GGTCTTTGGCCATAATTTCC 3' \\
SquaLWSR1 & LWS & 59.6 & 5' CCTTGCTGGCATTCTCTTCT 3' \\
SquaLWSR2 & LWS & 60.0 & 5' CCTTGCTGGCATTCTCTTCT 3' \\
SquaRh1F1 & Rh1 & 59.9 & 5' GCATTGTTCGGAGTCCATTT 3 \\
SquaRh1F2 & Rh1 & 60.4 & 5' TCTGGTTGGATGGTCAAGGT 3' \\
SquaRh1R1 & Rh1 & 61.6 & 5' GTGCTGGTCCTCCTCTGGTT 3' \\
SquaRh1R2 & Rh1 & 62.5 & 5' TTCTGCTGGCACCAAGACAG 3' \\
SquaSWS1F1 & SWS1 & 55.6 & 5' CCTCTTTGAAAACATCTCCTC 3' \\
SquaSWS1F2 & SWS1 & 59.8 & 5' GAGCAGGTTCATCCCAGAAG 3' \\
SquaSWS1R1 & SWS1 & 60.9 & 5' TTCTTTGGCTGGAGCAGGT 3' \\
SquaSWS1R2 & SWS1 & 59.8 & 5' GTCCTCCTGTCAAGTCAGCC 3' \\
\hline
\end{tabular}

O kit utilizado para as reações de PCR foi o rTth DNA Polymerase (Life Technologies, California, EUA) e as condições para cada par de primer foram as seguintes: desnaturação inicial a $94^{\circ} \mathrm{C}$ por 1 min; 50 ciclos a $94^{\circ} \mathrm{C}$ por $15 \mathrm{seg}$, temperatura de annealing entre 58 e $62^{\circ} \mathrm{C}$ por 30 seg (Tabela 3), temperatura de extensão de $72^{\circ} \mathrm{C}$ por $30 \mathrm{seg}$; e uma extensão final a $72^{\circ} \mathrm{C}$, por $10 \mathrm{~min}$.

Os produtos de PCR foram visualizados por eletroforese em gel de agarose a $1,0 \%$ e mantidos a $-20^{\circ} \mathrm{C}$ até o momento da purificação. A purificação foi feita com o Kit Illustra GFX ${ }^{T M} P C R$ DNA and Gel Band Purification Kit (GE Healthcare, Little Chalfont, Buckinghamshire, UK), e o DNA purificado foi mantido a $-20^{\circ} \mathrm{C}$. O sequenciamento foi feito diretamente com o kit DYEnamic ET Dye Terminator $\left(\right.$ MegaBACE $^{\mathrm{TM}}$, GE Healthcare) e foi utilizado o sequenciador MegaBACE 1000 (GE Healthcare), do Instituto Israelita de Ensino e Pesquisa do Hospital Albert Einstein (IIEPAE). As sequências de nucleotídeos foram analisadas com o programa BioEdit v7.0.9 (Hall, 1999).

Após análises dos produtos sequenciados, novos conjuntos de primers mais específicos para serpentes Caenophidia foram desenhados e utilizados para amplificação dos genes expressos (Tabela 4). O kit para PCR foi o mesmo que o descrito 
anteriormente e as condições para cada par de primer foram: desnaturação inicial a $94^{\circ} \mathrm{C}$ por $1 \mathrm{~min} ; 37$ ciclos (para os genes Rh1 e LWS) ou 50 ciclos (para o gene SWS1) a $94^{\circ} \mathrm{C}$ por $15 \mathrm{seg}$, temperaturas de annealing entre $58^{\circ} \mathrm{C}$ e $64^{\circ} \mathrm{C}$ por $30 \mathrm{seg}$ (Tabela 4 ), temperatura de extensão de $72^{\circ} \mathrm{C}$ por $30 \mathrm{seg}$; e uma extensão final a $72^{\circ} \mathrm{C}$ por $10 \mathrm{~min}$.

Tabela 4. Descrição dos primers utilizados para amplificar os três genes de opsinas expressos em retinas de serpentes Caenophidia.

\begin{tabular}{c|ccl} 
Primer & Opsina & Temp annealing & \multicolumn{1}{c}{ Sequência de Nucleotídeos do Primer } \\
\hline Rh1SmikFw & Rh1 & 65,8 & 5'TATTTGGCAGATCCATGGAAATATTCTG 3' \\
RhiSmikRv & Rh1 & 66,1 & 5'GGGGAAACCTTACTTGTGGAGACTGTAG 3' \\
Rh1OxyFw & Rh1 & 64,5 & 5'GTCACCATCCAACACAAGAAACTCA 3' \\
Rh1OxyRv & Rh1 & 64 & 5'AAATCACTGGGTTGTAGATTGAAGAGC 3' \\
SWS1ArtfFw & SWS1 & 64 & 5' GACGGTCCCCAGTATCACATTG 3' \\
SWS1 ArtfRv & SWS1 & 64,7 & 5' CTTGACAGGAGGACACTGAGGAAAC 3' \\
SWS1 TdorFw & SWS1 & 63,7 & 5' CTTTCCACTTCCAAACCATCTTCAT 3' \\
SWS1 TdorRv & SWS1 & 63,4 & 5' TTCTGAGAAGTCACATCAGAGTCGT 3' \\
SWS1 Tdor2Fw & SWS1 & 64,8 & 5' ATCCTCTTCGTCACCATCAAGTACAAG 3' \\
SWS1 Tdor2Rw & SWS1 & 64,1 & 5'ATGAAGCAGTAGATGATGGGGTTGT 3' \\
SWS1 DipsFw & SWS1 & 62 & 5'TACCACCAGGGAGAGTGTATTTGTGTA 3' \\
SWS1 DipsRv & SWS1 & 62 & 5' ACTTTCTTGCCAAAGAGCTGCATTAT 3' \\
LWS DipsFw & LWS & 62 & 5'CTTCGTCACCATCAAGTACAAGAAGT 3' \\
LWS DipsRv & LWS & 62 & 5'GTCTTCTGAGAGCTCAGGTCAGACT 3' \\
LWS DegFw & LWS & 62,4 & 5' GRYCCTTTTGAAGGYCCAAAYTAYC 3' \\
LWS DegRv & LWS & 62,8 & 5'GTTGTAAATGGTKGCGCTTTTTG 3' \\
LWS TdorFw & LWS & 61,6 & 5'TTTACTTACACCAACAGCAACAATACC 3' \\
LWS TdorRv & LWS & 61,5 & 5'TTCATGAAGACATAGATAATTGGGTTG 3' \\
LWS LpoeFw & LWS & 62,5 & 5'GTGTATTTGCTTACACCAATAGCAACA 3' \\
LWS LpoeRv & LWS & 63,4 & 5'AAAATGTATATGGTCCCCAGCAGAC 3' \\
\hline
\end{tabular}

Os produtos de PCR foram visualizados por eletroforese em gel de agarose a $1,0 \%$ e em seguida mantidos a $-20^{\circ} \mathrm{C}$ até o momento da purificação. A purificação foi feita com o mesmo kit descrito anteriormente e o DNA foi mantido a $-20^{\circ} \mathrm{C}$. Os sequenciamentos foram realizados com o kit Big Dye Terminator (Applied Biosystems) e foi utilizado o sequenciador 3500 Applied Biosystems, do Laboratório da Dra Maureen Neitz e do Dr Jeremy Neitz, da Universidade de Washington, Seattle, EUA, e com o sequenciador de mesmo modelo, do Instituto Israelita de Ensino e Pesquisa do Hospital Albert Einstein. As sequências foram analisadas com o programa Sequencher 5.0 (Gene Codes Corporation, EUA) ou com o programa BioEdit (Hall, 1999). 


\subsubsection{Análises filogenéticas}

As sequências de nucleotídeos dos pigmentos visuais Rh1, LWS e SWS1 das serpentes estudadas foram comparadas com as sequências das cinco classes de opsinas de outras espécies de vertebrados, obtidas a partir do banco de dados NCBI (Anexo 5), com a ferramenta de Blastn (Nucleotide Basic Local Alignment Search Tool).

As reconstruções filogenéticas foram desenvolvidas com 1354 pb dos pigmentos visuais amplificados neste trabalho e as sequências das 5 classes de opsinas obtidas do GenBank. A opsina ciliar do anelídeo Platynereis dumerilii (número de acesso no GenBank AY692353), foi utilizado como grupo externo. As análises filogenéticas foram realizadas usando os métodos de Máxima Verossimilhança (MV) e Análises Bayesianas (AB). Para estas análises, os modelos de substituição nucleotídica e os esquemas de partição ideais foram selecionados com o programa PartitionFinder V1.1.1 (Lanfear, 2012). As análises de MV foram realizadas com uso do programa GARLI v0.96 (Zwickl, 2006) e o suporte estatístico das árvores de ML foi estimado por bootstrap não paramétrico (Felsenstein, 1985), com 1.000 pseudoreplicações.

As análises Bayesianas foram desenvolvidas usando o software MrBayes 3.2 (Huelsenbeck \& Ronquist, 2001; Ronquist \& Huelsenbeck, 2003). As Markov Chain Monte Carlo (MCMC) foram iniciadas a partir de uma árvore aleatória, amostrando a cada 1.000 gerações a partir de duas corridas paralelas de $1.0 \times 10^{7}$ gerações. Pontos amostrados antes da fase de platô foram descartados como burn-in, e as árvores remanescentes foram combinadas para encontrar a probabilidade máxima da filogenia estimada a posteriori usando os programas Tracer v1.5 e TreeAnnotator v1.8 (Rambaut \& Drummond, 2007). As árvores resultantes foram visualizadas e editadas com o programa FigTree v1.4.2 (disponível em http://tree.bio.ed.ac.uk/software/figtree/). 


\subsubsection{Estimativa das curvas de absorção espectral das opsinas}

Aminoácidos em sítios específicos envolvidos no deslocamento espectral de cada um dos genes sequenciados, Rh1, LWS e SWS1, foram considerados para a inferência do pico de absorbância espectral das opsinas das diferentes espécies de serpentes. As sequências de aminoácidos das três opsinas foram alinhadas e as posições dos aminoácidos foram determinadas com base na sequência da rodopsina bovina (número de acesso no GenBank NM001014890) (Anexo 6).

As curvas de sensibilidade espectral foram estimadas a partir do método descrito por Stockman \& Sharpe (2000), adaptado pelo Dr. Balázs Vince Nagy, de acordo com a fórmula: $\log _{10}[\operatorname{toD}(\mathrm{x})]=a+b x^{2}+c x^{4}+d x^{6}+e x^{8}+f x^{10}+g x^{12}+h x^{14}$

onde, $x=\log 10(\lambda)-\log 10\left(\lambda_{\max } / 558\right)$, sendo $\lambda$ o comprimento de onda e $\lambda_{\max }$ o pico de sensibilidade espectral do fotopigmento, $a=-188862.970810906644, b=$ 90228.966712600282, $c=-2483.531554344362, d=-6675.007923501414, e=$ 1813.525992411163, $f=-215.177888526334, g=12.487558618387$ e $h=-$ 0.289541500599 .

\subsection{Estudos morfológicos da retina}

\subsubsection{Técnica de Nissl para coloração de células da CCG}

Os neurônios da camada de células ganglionares (CCG) foram corados pela técnica de Nissl, e sua densidade e distribuição foi determinada em montagens planas das retinas. A técnica de Nissl consiste no uso de corante de caráter básico, como o violeta de cresila, com afinidade pelos corpúsculos ou grânulos de Nissl, presentes no citoplasma de neurônios. Estes grânulos são compostos pelo retículo endoplasmático rugoso, com ribossomos, sendo estes acúmulos basófilos. A presença dos grânulos de Nissl é notada por coloração intensa devido a sua afinidade pelo corante básico. 
Após a eutanásia e tomadas das medidas dos animais, os olhos foram enucleados e a parte anterior que compreende a íris, córnea e cristalino, foi removida para obtenção da cuia óptica com a retina. Um pequeno corte radial foi feito na região dorsal da cuia óptica, para auxiliar na orientação da retina durante a montagem na lâmina. As retinas foram cuidadosamente dissecadas sob lupa estereomicroscópica (Nikon SMZ800) e fixadas em formalina $10 \%$. Após a fixação, as retinas foram aplanadas sobre lâminas histológicas gelatinizadas, com a CCG voltada para cima. Pequenos cortes radiais foram feitos ao longo da borda da retina para possibilitar a sua montagem e aderência à lâmina.

Sobre a retina foi colocado um papel filtro embebido em formalina $10 \%$ e por cima outra lâmina. O material foi mergulhado e mantido em formalina 10\% por 1 hora, com um peso de cerca de $200 \mathrm{~g}$ sobre as lâminas para garantir a adesão da retina. Após este período teve início o processo de hidratação do tecido, em concentrações decrescentes de álcool (de 95\% até 50\%) e água. As retinas foram coradas em solução aquosa de violeta de cresila $0,05 \%$ por 15 minutos e depois passaram por uma série de banhos em concentrações crescentes de álcool para desidratação (de $70 \%$ até 100\%), finalizando com xilol. As lâminas foram montadas com DPX e observadas em microscópio de luz (Leica DMRXE, Nussloch, Alemanha).

Uma vez que as retinas ficaram bem aderidas à lâmina durante todo o processo de coloração, o encolhimento da retina foi restrito aos limites da ora serrata e bordas dos cortes radiais, e portanto, foi desconsiderado (Hughes, 1975; Wässle et al., 1981; Peichl, 1992; Coimbra et al., 2012).

Os mesmos critérios citológicos propostos por Wong (1989) para a retinas de serpentes foram utilizados para distinguir células neuronais e não neuronais na CCG. Células da glia, identificadas pelo seu tamanho reduzido e perfil arredondado, com 
coloração escura (Ehrlich, 1981; Hart et al., 2012), não foram incluídas na contagem. Entretanto, células ganglionares não foram diferenciadas das células amácrinas deslocadas (Ehrlich, 1981; Hayes, 1984; Hart, 2002), uma vez que não foi possível distinguir com confiança os dois tipos celulares com base em critérios citológicos.

Em algumas das retinas coradas pela técnica de Nissl, foi possível visualizar também a camada de fotorreceptores e nestes casos, as células de cada camada foram quantificadas separadamente nos mesmos campos amostrais para comparação da densidade e topografia de neurônios da CNE e da CCG em uma mesma retina.

\subsubsection{Técnica de imunohistoquímica para marcação de fotorreceptores}

A técnica de imunohistoquímica consiste na utilização de anticorpos produzidos em um organismo, contra proteínas específicas de outro. Estes anticorpos primários são incubados com os tecidos em estudo, para que se liguem às proteínas específicas a serem localizadas. A reação é então revelada com o uso de anticorpo secundário, específico contra o primário, acoplado a uma molécula fluorescente, ou outro tipo de molécula que permita a vizualização.

Um olho de cada espécie foi utilizado para obtenção de cortes radiais e testes com diferentes anticorpos em diferentes concentrações. Após a enucleação do olho, a córnea e o cristalino foram removidos para obtenção da cuia óptica. Estes procedimentos foram realizados sob baixa luminosidade e com auxílio de lupa estereomicroscópica (Nikon SMZ800). Cada cuia óptica foi fixada em paraformaldeido (PFA) a 4\%, diluído em tampão fosfato (PB) $0,1 \mathrm{M}, \mathrm{pH} 7,4$, durante 3 horas e em seguida lavada em PB 0,1M. Depois de crioprotegidas com solução de sacarose $30 \%$ diluída em PB 0,1M por 24 horas, cada cuia óptica foi embebida em Tissue-Tek OCT, congeladada, e criosseccionada a $12 \mu \mathrm{m}$ de espessura. Os cortes foram feitos a $-25^{\circ} \mathrm{C}$ 
em criostato Leica JUNG CM 3000 (Nussloch, Alemanha), pertencente ao Laboratório de Biologia Celular da Retina do Departamento de Biologia Celular e do Desenvolvimento do Instituto de Ciências Biomédicas ICB I da USP, sob coordenação da Prof Dra. Dânia Emi Hamassaki, ou no criostato de bancada Leica CM1100 (Nussloch, Alemanha), do Laboratório de Psicofisiologia Sensorial do Instituto de Psicologia, USP. Os cortes foram posicionados sobre lâminas histológicas gelatinizadas, secos a $37^{\circ} \mathrm{C}$ por 1 hora e congelados a $-20^{\circ} \mathrm{C}$ até o momento de uso.

Para as montagens planas as retinas foram cuidadosamente dissecadas da cuia óptica, com auxílio de lupa estereomicroscópica (Nikon SMZ800), e fixadas em PFA 4\% diluído em PB 0,1 M, pH 7.4, por 2 horas. Após este período as retinas foram mantidas em PB 0,1 M, e estocadas a $4^{\circ} \mathrm{C}$ até o uso.

Para a marcação das opsinas, retinas íntegras e cortes radiais foram préincubados durante 1 hora em soro normal de cabra 10\% (Sigma-Aldrich, St. Louis, MO, EUA), diluído em PB a 0,1 M com Triton X-100 a 0,3\%, para bloqueio dos sítios inespecíficos. As retinas foram então incubadas com anticorpo primário diluído em PB 0,1 M com Triton X-100 0,3\% durante 3 dias, a $4^{\circ} \mathrm{C}$. Os cortes radiais foram incubados em temperatura ambiente por 24 horas. Após este período os tecidos passaram por três lavagens de 10 minutos em PB 0,1 M com Triton X-100 0,3\%, antes de serem incubados com o anticorpo secundário (anticorpo de cabra contra soro de coelho, 1:200; Jackson Immunoresearch Laboratories, West Grove, PA, EUA), acoplado a molécula fluorescente Rodamina (TRITC) ou Fluoresceína (FITC), diluído em PB 0,1 M com Triton $0,3 \%$, durante 2 horas. Após a incubação com o anticorpo secundário, foram feitas três lavagens de 10 minutos em PB $0,1 \mathrm{M}$. Pequenos cortes radiais nas retinas íntegras foram feitos para possibilitar a sua aplanagem sobre a lâmina. As lâminas foram montadas com meio de montagem para fluorescência Vectashield com DAPI 
(Vector Laboratories, California, EUA). A especificidade do anticorpo secundário foi avaliada por incubação de cortes radiais em solução tampão com a omissão do anticorpo primário. Nenhuma marcação pelo anticorpo secundário foi detectada.

As lâminas foram observadas com microscópio de fluorescência (Leica DMRXE, Nussloch, Alemanha) com objetiva de 40x oil $(\mathrm{NA}=0.7)$ ou de 100x oil (abertura numérica, NA $=1.25$ ), com um conjunto de filtros específicos para TRITC (excitação verde, emissão vermelho), ou para FITC (excitação azul, emissão verde). Nas montagens planas, a população de fotorreceptores foi observada ajustando o foco na camada dos segmentos internos dos fotorreceptores. Os diferentes tipos de fotorreceptores marcados pelos anticorpos foram observados ajustando o foco do microscópio à camada dos segmentos externos dos fotorreceptores.

\section{Caracterização e especificidade dos anticorpos}

A incubação primária com anticorpos anti-opsinas foi realizada com dois anticorpos de coelho, JH492, contra opsinas de cone L/M de humanos, e JH455, contra opsinas de cone $\mathrm{S}$ de humanos, desenvolvidos e gentilmente fornecidos por Jeremy Nathans e colaboradores (Nathan et al., 1986), da Johns Hopkins University School of Medicine, Baltimore, MD, EUA. Foram utilizados também os anticorpos de coelhos, AB5405, contra opsinas de cones L/M de humanos e AB5407, contra opsinas de cones $\mathrm{S}$ de humanos, e o anticorpo de galinha AB5745, contra opsinas de cones L/M de humanos (Millipore Corporation, Billerica, MA, EUA).

Os anticorpos JH492 e JH455 foram caracterizados por Wang et al. (1992). Os segmentos de DNA que codificam os últimos 38 aminoácidos do pigmento L de humano (RQFRNCILQLFGKKVDDGSELSSASKTEVSSVSSVSPA; número de acesso no GenBank: NM020061) e os últimos 42 aminoácidos do pigmento S de humano (NKQFQACIMKMVCGKAMTDESDTCSSQKTEVSTVSSTQVGPN; 
número de acesso no GenBank: NM001708) foram separadamente introduzidos no poliligante do gene T7 do vetor de expressão 10 pGEMEX (Promega, Madison, WI, EUA). Cada peptídeo derivado do pigmento de cone foi produzido como uma extensão carboxi-terminal da proteína 10 do gene T7 (Studier et al., 1990). As quatro proteínas fundidas foram purificadas por electroforese em gel de poliacrilamida e utilizadas para imunizar coelhos. Uma descrição completa de suas características e propriedades de coloração foi descrito por Schiviz et al. (2008).

Além dos anticorpos citados acima, foram utilizadas também duas aglutininas para marcação e diferenciação de cones e bastonetes: a aglutinina WGA (rhodamine wheat germ agglutinin), isolada de gérmen do trigo (Triticum vulgaris), que se liga a oligossacarídeos contendo terminal $\mathrm{N}$-acetylglucosamine, conjugado a molécula fluorescente rodamina (TRITC), utilizada na retina de vertebrados para marcar bastonetes (Sameshima et al., 1987); e a lectina PNA (fluorescein lectins peanut agglutinin), isolada do amendoim (Arachis hypogaea) que se liga preferencialmente a galactosil (b-1,3) N-acetylgalactosamine, carboidrato presente em muitos glicoconjugados, conjugado à molécula fluoresceína (FITC) e usado na retina de vertebrados para marcação de cones (Sameshima et al., 1987) (Vector Laboratories, California, USA). Alíquotas dos dois marcadores foram gentilmente cedidas pela Prof

Dra Dânia Emi Hamassaki do Laboratório de Biologia Celular da Retina do Departamento de Biologia Celular e do Desenvolvimento do Instituto de Ciências Biomédicas ICB I da USP.

\subsubsection{Densidade e distribuição de neurônios nas retinas}

A distribuição de fotorreceptores e de células da CCG de cada retina plana foi avaliada por meio de amostragem aleatória sistemática e o princípio de fracionamento (Gundersen, 1977; Coimbra et al, 2009, 2012; Ullmann et al, 2012; Lisney et al., 2013). 
As coordenadas das bordas das retinas foram obtidas e plotadas em uma planilha de Excel e as contagens de células foram feitas em intervalos regulares definidos por uma grade de amostragem, com espassamento variando de 120 x $120 \mu \mathrm{m}$ a $1300 \times 1300 \mu \mathrm{m}$, dependendo da área da retina. As coordenadas dos campos amostrados foram inseridas na mesma planilha de Excel, assim como os valores do número de células contadas por campo.

A contagem foi feita através da visualização direta da retina sob microscópio Leica DMRXE, com uma objetiva de $100 \times$ oil (abertura numérica, NA $=1,25$ ) ou 40×oil $(\mathrm{NA}=0.7)$, equipado com uma câmera Nikon Digital Sight DS-U3 DSRi1 e software NIS-Elements AR Microscope Imaging software (Nikon Instruments, Melville, NY, EUA), ou a partir de imagens obtidas de cada campo amostrado, com o mesmo sistema de obtenção de imagens, ou com o programa Axio Vision (Carl Zeiss, Jena, Alemanha), através de câmara digital Axio CamMR (Carl Zeiss, Jena, Alemanha) acoplada a microcomputador, e uso do programa NIH Scion Image 2.0 (Scion Image Corporation) para a contagem de células em cada campo. Um quadro de amostragem de tamanho que variou desde 32 × $32 \mu \mathrm{m}$ até 194 x $194 \mu \mathrm{m}$, dependendo do número de células por campo, foi imposto sobre cada campo amostrado. As células foram contadas se inseridas totalmente dentro do quadro de contagem ou se encostassem nas linhas de aceitação, sem tocar as linhas de rejeição (Gundersen, 1977).

O número de células quantificadas em cada ponto amostrado foi inserido na planilha e convertido em valor de densidade, dividindo o número de células pela área do quadro de amostragem e multiplicando este número por $10^{6}$, para obtenção do valor de densidade de células por por $\mathrm{mm}^{2}$. A densidade média de células de cada retina foi estimada a partir da média dos valores de densidade de cada campo. O número total de células da retina foi estimado multiplicando o valor de densidade média pela área total 
da retina. Outro método equivalente para estimativa da população total de células da retina leva em consideração a área da fração de amostragem (area of sampling fraction - asf), que corresponde à área do quadro de amostragem, dividida pela área da grade de amostragem, de acordo com a fórmula: $\mathrm{N}=$ total de $\mathrm{RQ} \times 1 /$ asf, onde RQ é a soma do total de neurônios contados (West et al., 1991; Coimbra et al., 2009, 2013).

As informações sobre os parâmetros estereológicos utilizados para amostragem de células da CCG e de fotorreceptores de cada retina estão descritos nos Anexos 7 e 8: tamanho do quadro de amostragem (couting frame), grade de amostragem (grid), a área calculada da fração de amostragem (asf) e a objetiva utilizada, bem como a área total da retina e o número de campos amostrados. Os coeficientes de erro (CE) foram calculados usando o método de Schaeffer et al. (1996) e foram iguais ou menores que 0,01 para todas as retinas, indicando que as estimativas totais número de células tiveram um alto grau de precisão (Boire et al., 2001; Coimbra et al., 2009; Ullmann et al., 2012).

Para elaboração dos mapas de isodensidade, foi utilizado o programa DeltaGraph 4.0 (DeltaPoint, Monterey, CA, EUA), no qual foram inseridas as coordenadas de cada campo amostrado e os respectivos valores de densidade de células. Para obter uma cobertura completa do mapeamento da retina, alguns pontos adicionais com valores ligeiramente mais baixos em relação àqueles amostrados ao longo da borda da retina foram colocados além do contorno da retina (Schiviz et al., 2008). A posição da retina foi determinada com base no ponto do nervo óptico, localizado no quadrante ventro-temporal, e pela pequena incisão radial feita na região dorsal antes da dissecção.

\subsubsection{Avaliação da distância focal e estimativa do poder de resolução espacial}

Estimativas do pico teórico do poder de resolução espacial foram calculadas utilizando a densidade máxima de células da CCG e a distância focal do olho, 
representado pela distância posterior nodal (PND), do centro do cristalino até a borda da coróide-retina (Sivak, 1976).

Para estimativa anatômica da distância focal, olhos de duas espécies de serpentes, a noturna S. neuwiedi e da diurna T. dorsatus, foram congelados e cortados nos planos axiais e equatoriais (Lisney \& Collin, 2008). Os olhos foram rapidamente congelados numa mistura de gelo seco e etanol (Sivak, 1978) e armazenados a $-30{ }^{\circ} \mathrm{C}$. Depois de observar a orientação, cada olho foi emblocado em Tissue-Tek composto OCT (Sakura Finetechnical, Tóquio, Japão), e os blocos foram cortados em criostato a $25{ }^{\circ} \mathrm{C}$ (Leica CM 1100, Nussloch, Alemanha). Fotografias da face do bloco foram tomadas a cada $100 \mu \mathrm{m}$. A fotografia que apresentou a maior espessura da lente foi identificada e usada para as medições ópticas (Figura 23). As medidas do comprimento axial do olho, diâmetro axial da lente e distância focal, representada pelo PND foram tomadas ao longo do eixo óptico, o qual foi localizado ligando os centros geométricos dos componentes ópticos (Lisney e Collin, 2008). A medida do PND foi obtida para representar a distância focal e utilizada no cálculo do poder de resolução espacial.

O PND de cada olho foi estimado multiplicando o seu comprimento axial por 0,52. Pettigrew et al. (1988) propuseram que o PND dos olhos de vertebrados noturnos tem uma média de 0,52 do tamanho do olho, enquanto que as espécies diurnas tem uma média de 0,67. Embora algumas das serpentes apresentem hábitos diurnos, a distância focal estimada foi de 0,52 para os olhos de todas as espécies, dado o tamanho relativamente grande do cristalino rígido e esférico de todas as espécies, e os resultados obtidos com as imagens dos cortes de olhos de S. neuwiedi e T. dorsatus (Figura 23). Os valores do diâmetro axial e PND de cada olho analisado para amostragem de células da CCG estão descritos na Tabela 5. 

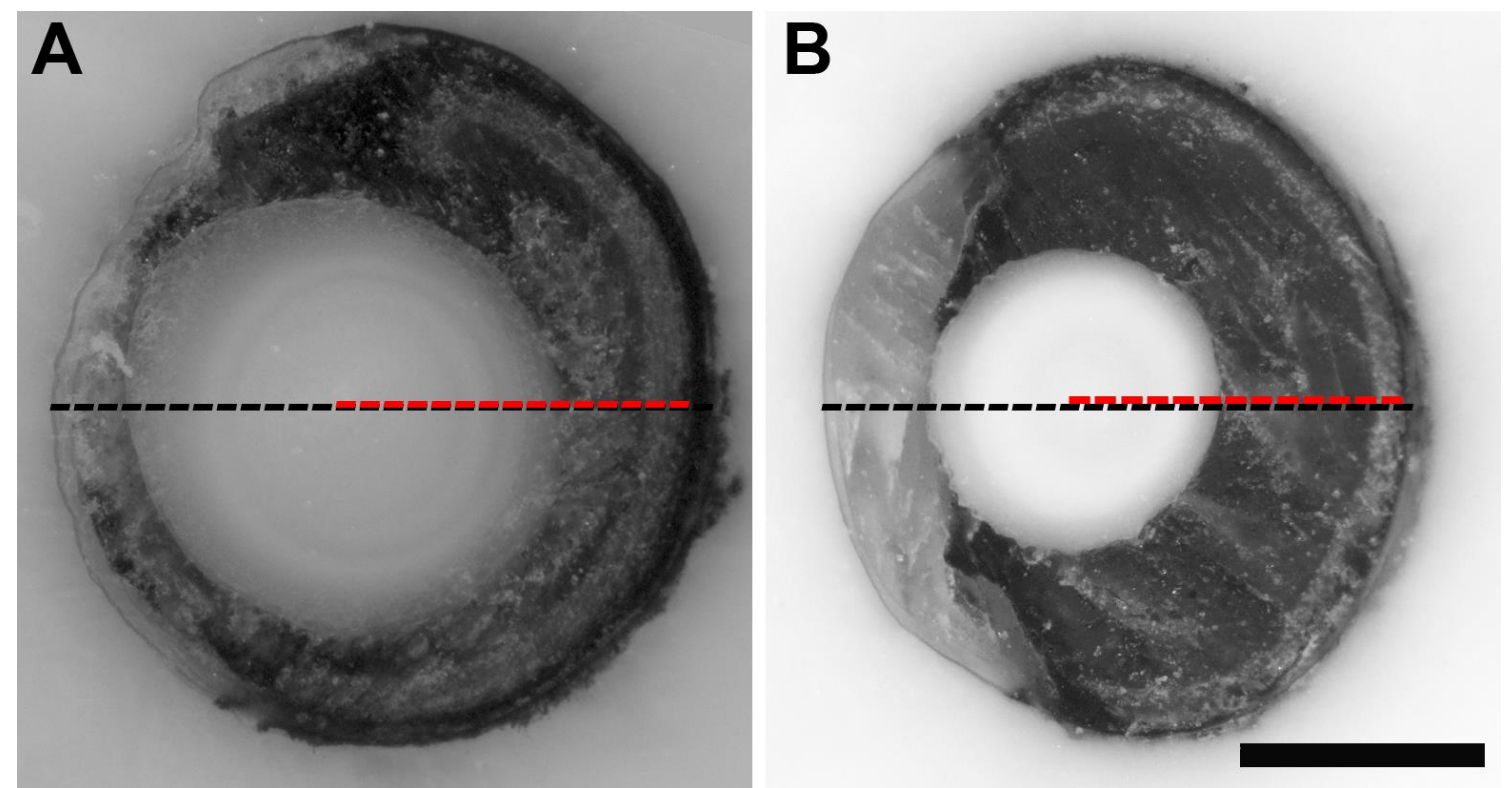

Figura 23. Corte transversal de olho da serpente noturna Sibynomorphus neuwiedi (A) e da diurna Tomodon dorsatus (B). A distância posterior nodal (PND), do centro do cristalino até a borda da retina-coróide, está representada pela linha tracejada em vermelho e corresponde a cerca de $52 \%$ do diâmetro axial do olho. Barra de escala $1 \mathrm{~mm}$.

Para estimativa teórica do poder de resolução espacial foi utilizado o método proposto por Hart (2002), em que a distância $d$ subtendida como um grau na retina é determinada a partir do PND e calculada de acordo com a fórmula $d=(2 \pi \mathrm{PND}) / 360$. Assumindo que o espaçamento entre as células ganglionares é o fator limitante para a resolução espacial em retinas de serpentes, e que os campos destas células estão dispostos em aproximadamente um arranjo hexagonal, foi calculada a média do espaçamento entre as células, $S$, de acordo com a fórmula $S^{2}=2$ / (D $\left.\sqrt{3}\right)$, em que D é o valor de densidade máxima de células ganglionares, por $\mathrm{mm}^{2}$. A frequência espacial máxima (v) de uma grade senoidal que tem resolução com tal arranjo celular (Snyder \& Miller, 1977) foi calculada com a fórmula $v=1 /(\mathrm{S} \sqrt{3})$. Este valor foi multiplicado pela distância $d$ para obtenção do valor de resolução espacial em ciclos por grau. 


\subsubsection{Análises estatísticas}

As análises estatísticas foram realizadas usando o programa SPSS Statistic v.20.0 (IBM Corporation, Armonk, NY, USA), para comparar os valores de densidade média e população total dos diferentes tipos neurônios das retinas de serpentes diurnas e noturnas, bem como as áreas das retinas e o poder de resolução espacial.

A distribuição dos valores de cada variável de cada grupo foi avaliada pelo teste de Kolmogorov-Smirnov e a homocedasticidade entre os grupos foi avaliada pelo teste de Levene. Em seguida, foram realizados testes $t$ para amostras independentes, para verificar possíveis diferenças entre as médias dos grupos de serpentes diurnas enoturnas, para cada variável analisada. Nas ocasiões em que um dos grupos tinha menos de 12 indivíduos, foi realizado também uma comparação através do teste não paramétrico de Mann-Whitney, mesmo que o teste de Kolmogorov-Smirnov tenha apontado normalidade de distribuição dos dados. Vale ressaltar que não houve discordância em termos de significância estatística entre os testes $t$ e Mann-Whitney realizados, o que reforça os resultados do primeiro. O nível de significância adotado em todas as comparações foi de $5 \%$. 


\section{RESULTADOS}

\subsection{Genética de opsinas}

\subsubsection{Análises filogenéticas}

A comparação das sequências de nucleotídeos dos genes de opsinas de serpentes com as sequências dos pigmentos visuais de outros vertebrados (Anexo 5), mostraram que os genes amplificados correspondem aos dos pigmentos visuais de rodopsina (Rh1), de cones L (LWS) e de cones UV (SWS1). Os alinhamentos dos aminoácidos dos três pigmentos visuais das espécies estudadas, juntamente com os das serpentes Henophidia descritos na literatura (números de acesso no GenBank: FJ497233 - FJ497238) e com a rodopsina bovina (NM001014890), são apresentados no Anexo 6.

Os modelos selecionados para as análises filogenéticas (MV e AB) foram TVMef + I + G para a posição 1 e 2 no códon e TIM + I + G para a posição 3 no códon. A análise Bayesiana $(\mathrm{AB})$ recuperou uma topologia consenso similar à melhor árvore de MV. As análises filogenéticas recuperaram a monofilia de cada um dos 5 grupos de opsinas com alto suporte na AB. A topologia e o suporte bayesiano sugerem a formação de dois grupos: o primeiro constituído por LWS e o segundo por SWS1, SWS2, Rh1 e Rh2. No segundo grupo, SWS1 diverge mais cedo na filogenia, seguido por SWS2, e Rh1 e Rh2 são grupos irmãos derivados. Estes resultados permitem corroborar a identidade dos genes das serpentes, ortólogos aos dos demais vertebrados.

As análises englobando todos os genes serão apresentadas na Figura 24. Nas subsequentes Figuras (25 a 27) serão ampliados separadamente os resultados cujas análises englobaram os genes obtidos para as amostras de serpentes (LWS, SWS1 e Rh1). 


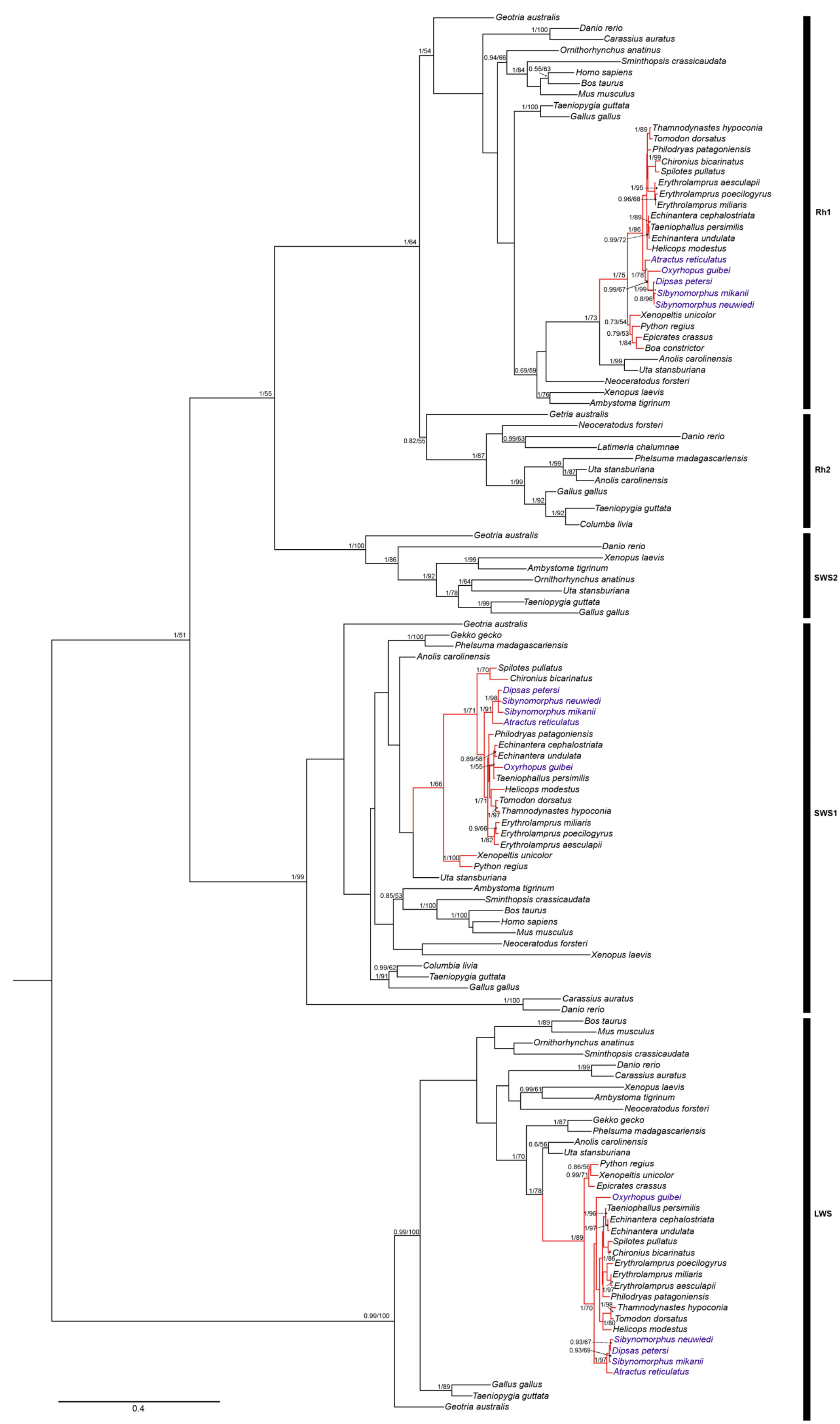

Figura 24. Análise filogenética das sequências de nucleotídeos das cinco classes de opsinas de vertebrados, construída pelo método de Máxima Verossimilhança (MV). A topologia da $\mathrm{AB}$ recuperou uma topologia consenso similar à melhor árvore de MV. Grupo das serpentes destacado em vermelho. As espécies de hábitos noturnos do grupo Caenophidia estão representadas em azul. A opsina ciliar do anelídeo Platynereis dumerilii (GenBank: AY692353), foi utilizado como grupo externo (dado não mostrado). Os valores apresentados correspondem à probabilidade posterior $(\mathrm{PP})$ na $\mathrm{AB}$ e os valores de suporte obtidos por bootstrap na análise de $\mathrm{MV}$, obedecendo a ordem $\mathrm{AB} / \mathrm{MV}$. A barra de escala representa o número de substituições de nucleotídeos por sítio. 
As análises do gene LWS (Figura 25) recuperaram a relação entre as linhagens de serpentes Henophidia (P. regius, X. unicolor e E. crassus), e as demais serpentes do grupo Caenophidia, com alto suporte na AB e MV. O monofiletismo do clado formado pela subfamília Dipsadinae, representado pelas serpentes noturnas A. reticulatus, $S$. mikanii, S. neuwiedi e D. petersi, foi recuperado com suporte elevado. Entretanto, a linhagem, formada pelas serpentes da subfamília Xenodontinae juntamente com as serpentes família Colubridae (S. pullatus e C. bicarinatus) apresentou um padrão parafilético, sem suporte.

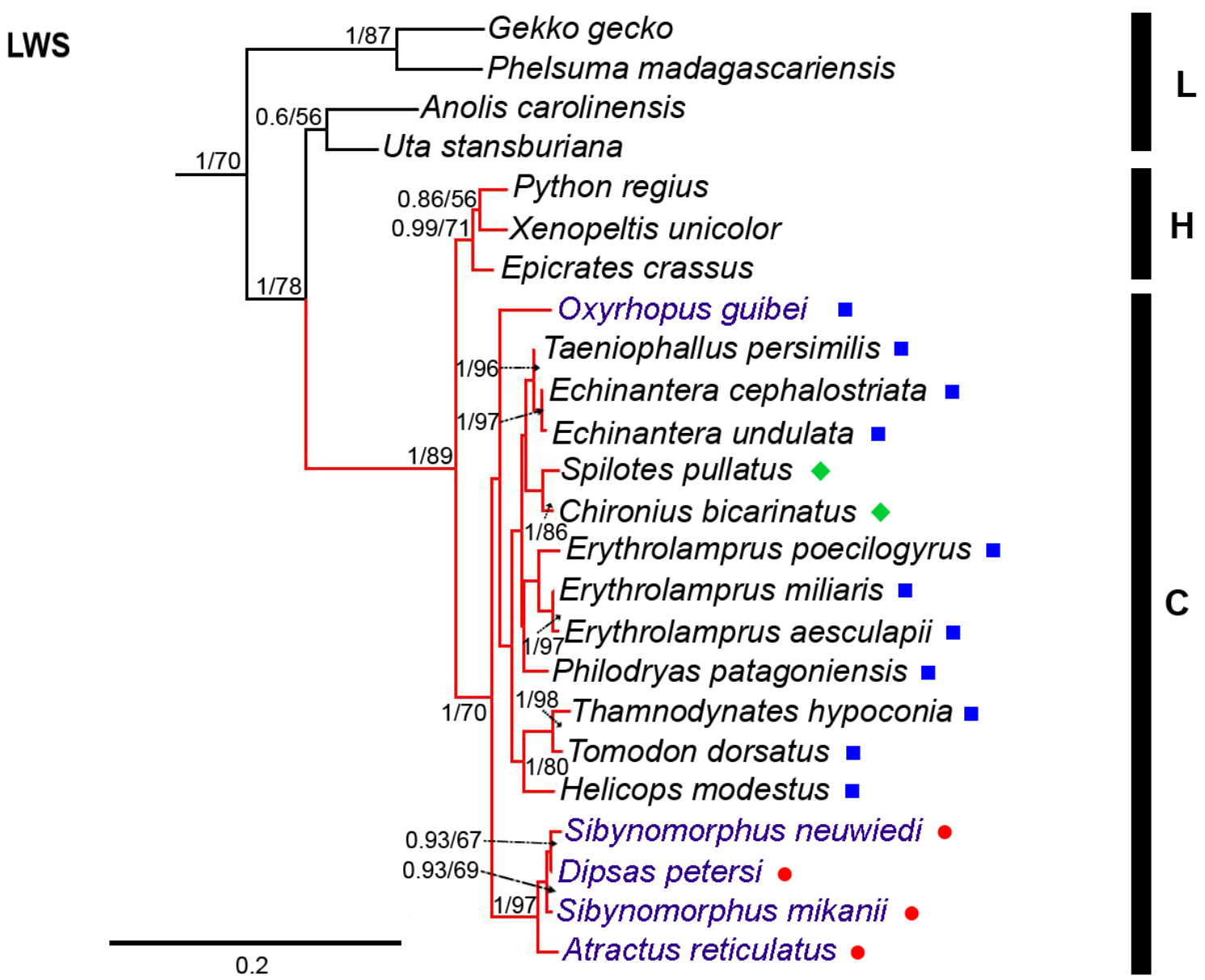

Figura 25. Análise filogenética das sequências de nucleotídeos das opsinas LWS de serpentes e lagartos, recuperada pelo método de Máxima Verossimilhança (MV). A topologia da AB recuperou uma topologia consenso similar à melhor árvore de MV. Grupo das serpentes destacado pelas linhas vermelhas. As espécies de hábitos noturnos do grupo Caenophidia estão representadas em azul. Os símbolos ao lado de cada espécie diferenciam as serpentes da família Colubridae $(\diamond)$, e das duas subfamílias da família Dipsadidae: Dipsadinae $(\bullet)$ e Xenodontinae (匹), conforme classificação de Zaher et al., 2009. As barras da direita distinguem os grupos Caenophidea (C), Henophidea $(\mathrm{H})$ e lagartos (L). Os valores apresentados nos nós correspondem às probabilidades bayesianas e aos suportes de bootstrap, respectivamente. A barra de escala representa o número de substituições de nucleotídeos por sítio. 
O clado formado pelo gene SWS1 de serpentes (Figura 26) apresentou alta probabilidade posterior na $\mathrm{AB}(100 \%)$, porém baixo suporte de bootstrap (66\%). A linhagem de serpentes Henophidia, representada por $P$. regius e $X$. unicolor foi recuperada, com alto suporte. Na linhagem de serpentes Caenophidia, os clados das famílias Colubridae (S. pulatus e $C$. bicarinatus) e Dipsadidae foram recuperados, com alto suporte. A subfamília Dipsadinae teve sua monofilia recuperada e Xenodontinae apresentou um padrão parafilético.

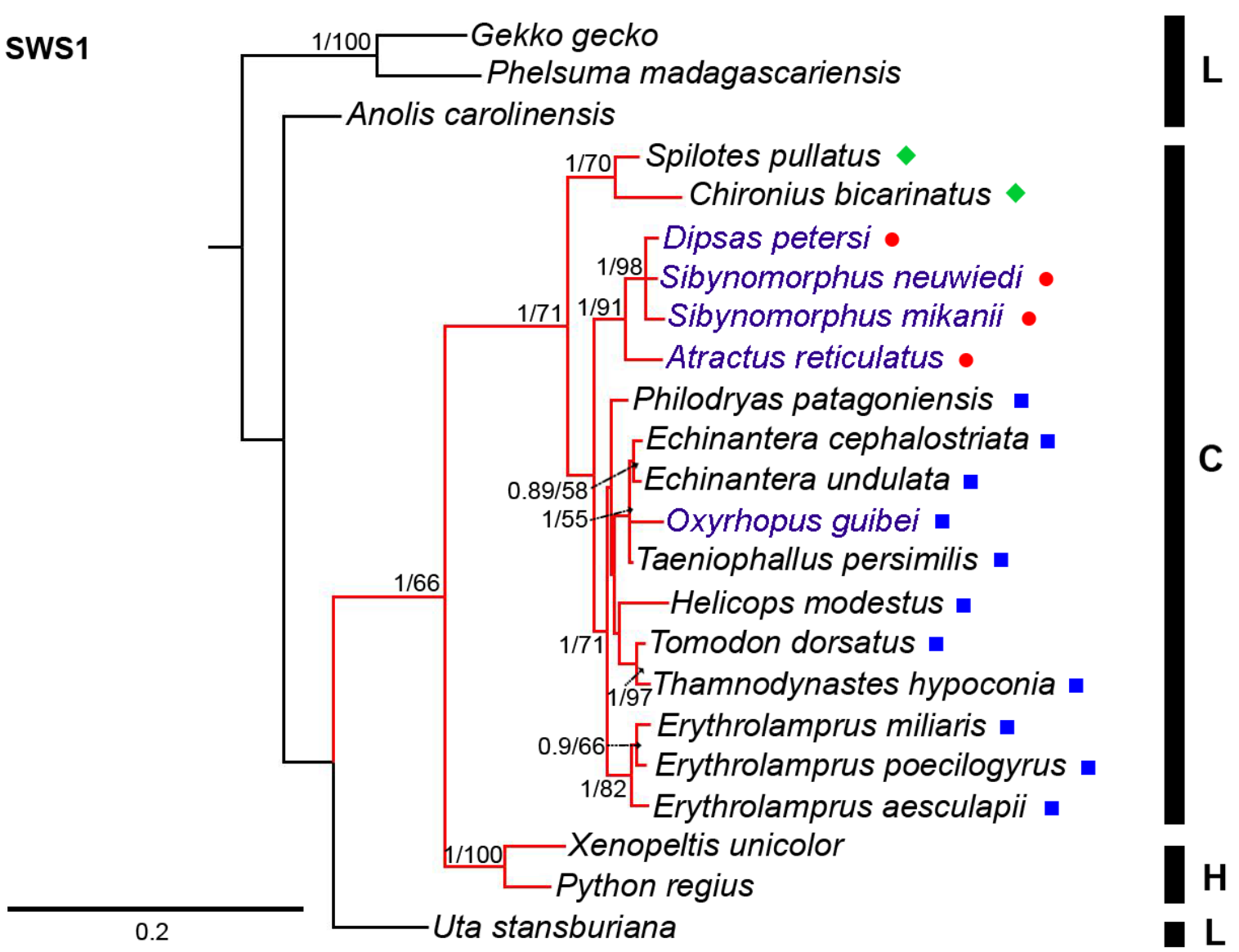

Figura 26. Análise filogenética das sequências de nucleotídeos das opsinas SWS1 de serpentes e lagartos, recuperada pelo método de Máxima Verossimilhança (MV). A topologia da AB recuperou uma topologia consenso similar à melhor árvore de MV. Grupo das serpentes destacado pelas linhas vermelhas. As espécies de hábitos noturnos do grupo Caenophidia estão representadas em azul. Os símbolos ao lado de cada espécie diferenciam as serpentes da família Colubridae $(\diamond)$, e das duas subfamílias da família Dipsadidae: Dipsadinae $(\bullet)$ e Xenodontinae (匹), conforme classificação de Zaher et al., 2009. As barras da direita diferenciam os grupos Caenophidea (C), Henophidea $(\mathrm{H})$ e lagartos (L). Os valores apresentados nos nós correspondem às probabilidades bayesianas e aos suportes de bootstrap, respectivamente. A barra de escala representa o número de substituições de nucleotídeos por sítio. 
As análises do gene Rh1 (Figura 27) recuperaram a relação entre as linhagens de serpentes Henophidia (P. regius, X. unicolor, B. constrictor e E. crassus), e as serpentes do grupo Caenophidia, com probabilidade posterior igual a $100 \%$ na $\mathrm{AB}$ e bootstrap moderado de $75 \%$ em MV. No grupo Caenophidia, a relação entre serpentes de hábitos diurnos e noturnos foi recuperada, com suportes elevados (100\% na $\mathrm{AB}$ e $86 \%$ na MV). Serpentes noturnas, incluindo todas da subfamília Dipsadinae, juntamente com a espécie O. guibei da subfamília Xenodontinae, formaram um grupo monofilético, com alto suporte. O grupo das serpentes diurnas, entretanto, apresentou um padrão parafilético, sem suporte, com serpentes da subfamília Xenodontinae e da família Colubridae.

\section{Rh1}

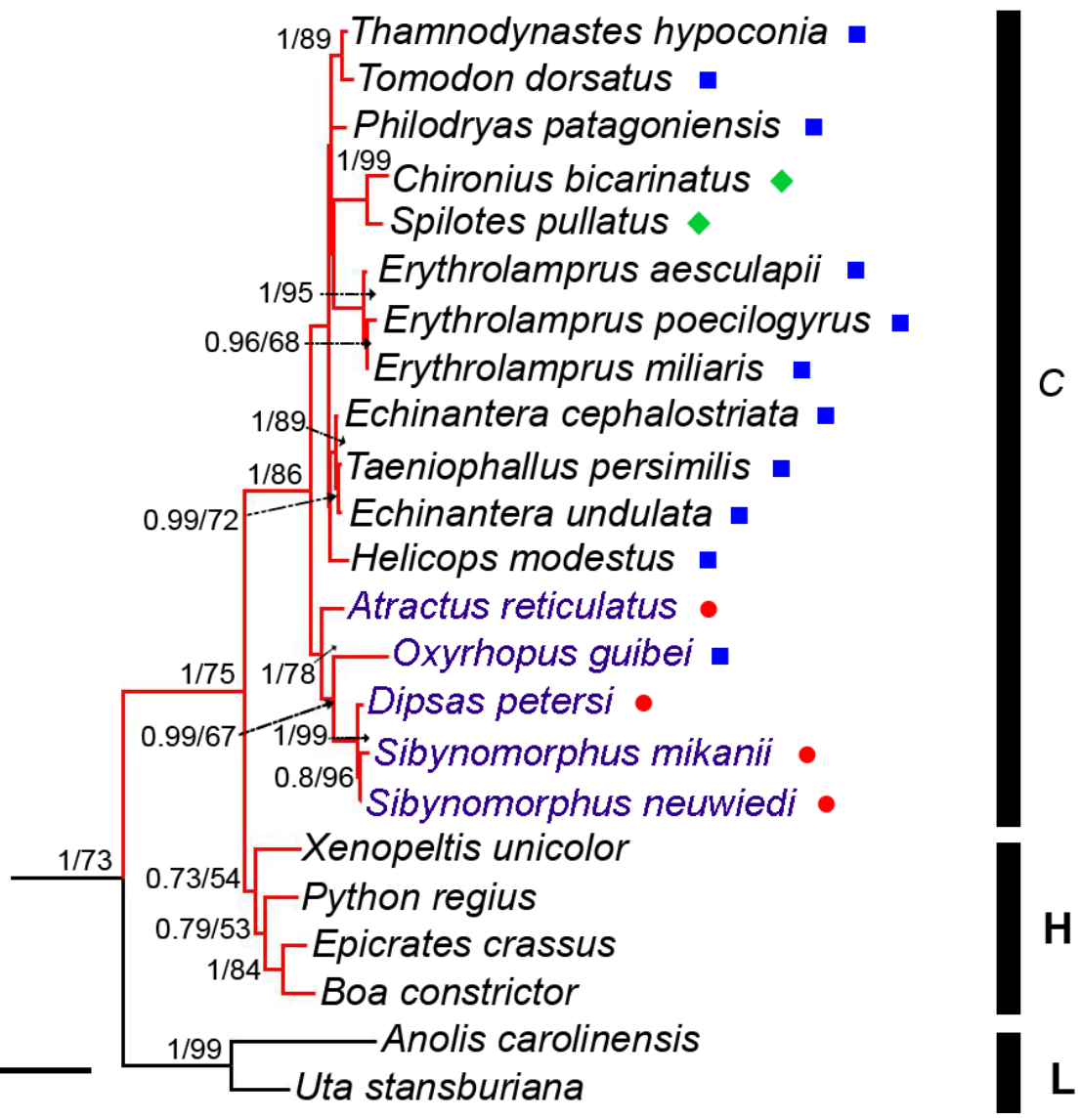

Figura 27. Análise filogenética das sequências de nucleotídeos das opsinas Rh1 de serpentes e lagartos, recuperada por MV. A topologia da $\mathrm{AB}$ recuperou uma topologia consenso similar de MV. Grupo das serpentes destacado pelas linhas vermelhas. As serpentes Caenophidia noturnas estão representadas em azul. Os símbolos ao lado de cada espécie diferenciam as serpentes da família Colubridae $(\diamond)$, e das duas subfamílias da família Dipsadidae: Dipsadinae $(\bullet)$ e Xenodontinae (ロ) (Zaher et al., 2009). As barras da direita diferenciam os grupos Caenophidea $(\mathrm{C})$, Henophidea $(\mathrm{H})$ e lagartos $(\mathrm{L})$. Os valores apresentados nos nós correspondem às probabilidades bayesianas e aos suportes de bootstrap, respectivamente. A barra de escala representa o número de substituições de nucleotídeos por sítio. 


\subsubsection{Sensibilidade espectral}

\section{Grupo Rh1}

Sete aminoácidos em regiões próximas ao retinal estão relacionados com o pico de sensibilidade espectral do pigmento Rh1 de vertebrados. A presença dos aminoácidos D83, E122, M207, H211, W265, A292 e A295 (DEMHWAA), gera um $\lambda_{\max }$ de $500 \mathrm{~nm}$ (Yokoyama, 2000). As mutações D83N e A292S foram observadas em algumas das espécies de serpentes estudadas, e causam deslocamento do $\lambda_{\max }$ para o azul em 6 e 10 $\mathrm{nm}$, respectivamente (Yokoyama, 2000).

A Figura 28 mostra as três possíveis curvas de sensibilidade espectral estimadas para as espécies de serpentes. As curvas foram traçadas conforme método adaptado de Stockman \& Sharpe (2000). O perfil DEMHWAA, que gera um pigmento Rh1 $\operatorname{com} \lambda_{\max }$ de $500 \mathrm{~nm}$ foi observado nas espécies noturnas D. petersi, O. guibei, S. mikanii, S. neuwiedi e na serpente do grupo Henophidia B. constrictor. A combinação NEMHWAA, com a mutação D83N, deve conferir a este pigmento visual um pico de sensibilidade espectral de $494 \mathrm{~nm}$, e foi observada apenas na serpente noturna $A$. reticulatus e nas serpentes Henophidia E. crassus, X. unicolor (FJ497233) e P. regius (FJ497236). O perfil NEMHWSA, com as mutações D83N e A292S, deve conferir um maior deslocamento para o azul, com $\lambda_{\max }$ de $484 \mathrm{~nm}$, e foi observado em todas as espécies de serpentes diurnas analisadas neste estudo: $C$. bicarinatus, E. cephalostriata, E. undulata, E. aesculapii, E. miliaris, E. poecilogyrus, H. modestus, P. patagoniensis, S. pullatus, T. persimilis, T. hypoconia e T. dorsatus. 


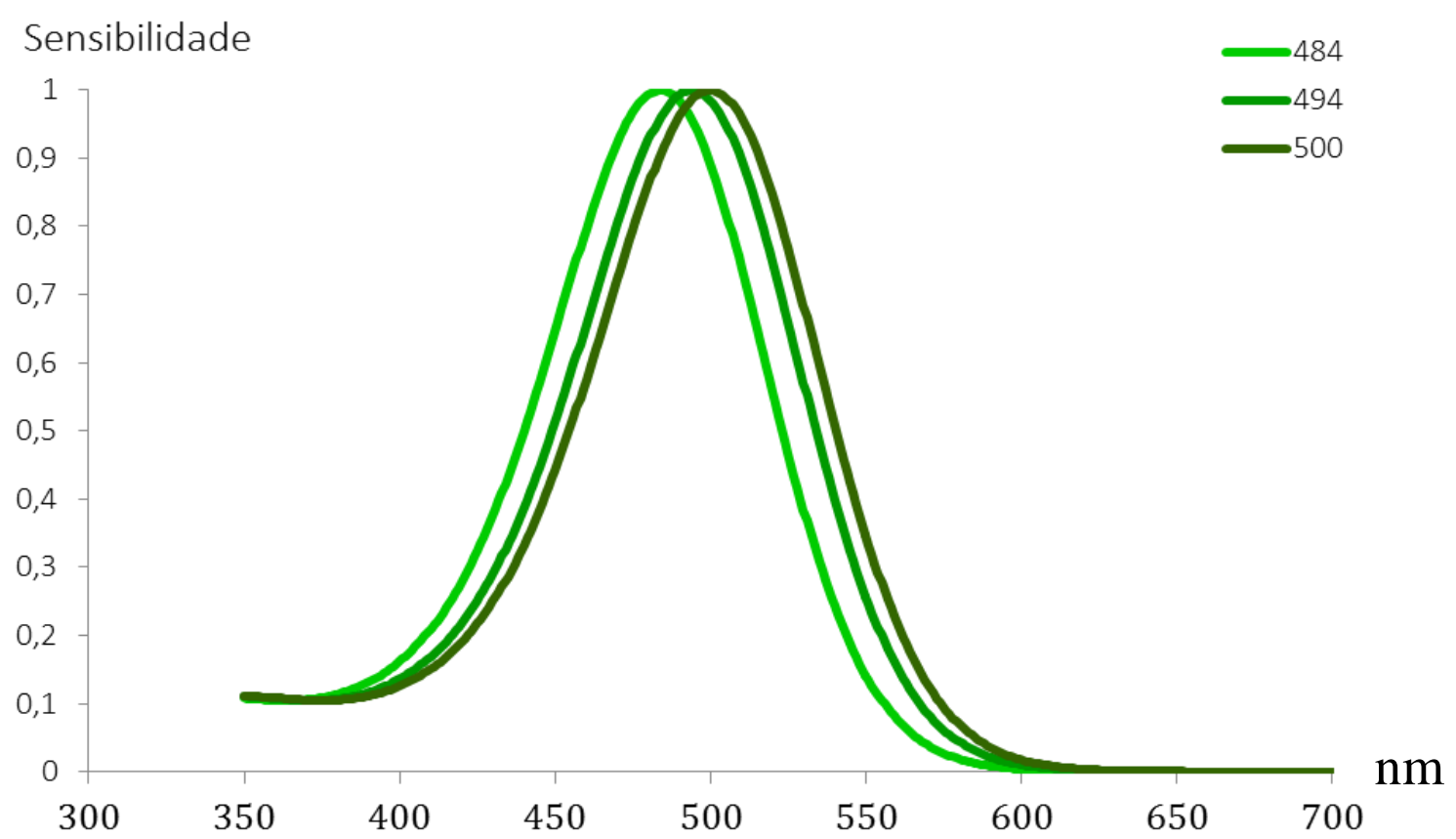

Figura 28. Curvas de sensibilidade espectral previstas a partir das sequências de aminoácidos do pigmento Rh1 de diferentes espécies de serpentes. A curva de $500 \mathrm{~nm}$ corresponde ao perfil DEMHWAA, a curva de $494 \mathrm{~nm}$ ao perfil NEMWHAA e a curva de $484 \mathrm{~nm}$ corresponde ao perfil NEMWHSA.

\section{Grupo SWS1}

O resíduo presente no sítio 86 se mostrou crítico para determinar o pico de sensibilidade espectral do pigmento visual SWS1 (Hunt et al., 2007). Com exceção de C. bicarinatus, que apresentou um aminoácido Valina neste sítio, e H. modestus que foi heterozigota, com os aminoácidos Valina e Fenilalanina, todas as demais espécies de serpentes estudadas apresentaram o resíduo F86, bem como $X$. unicolor (FJ497234) e $P$. regius (FJ497237), o que deve conferir ao fotopigmento SWS1 a sensibilidade ao UV na faixa de $360 \mathrm{~nm}$ (Figura 29), como descrito para outras espécies de vertebrados (Cowing et al., 2002; Fasick et al., 2002).

A literatura descreve que a mutação V86F causa um deslocamento de $60 \mathrm{~nm}$ do pigmento VS para o UV, mas que a mutação inversa F86V não é capaz de deslocar o pico de sensibilidade do pigmento UV para o violeta; tal deslocamento depende da interação com outros resíduos, como por exemplo, a presença de um aminoácido polar 
S90 (Parry et al., 2004). No caso das serpentes C. bicarinatus e H. modestus, assim como nas demais espécies estudadas, o sítio 90 é ocupado pelo resíduo apolar Alanina, indicando que apenas a mutação V86 não poderia ser responsável pelo deslocamento espectral do fotopigmento SWS1. Desta forma, considerou-se que o pigmento visual SWS1 de todas as espécies, incluindo de Chironius e Helicops tem sensibilidade espectral na faixa do UV, $\operatorname{com} \lambda_{\max }$ de $360 \mathrm{~nm}$ (Figura 29).

\section{Sensibilidade}

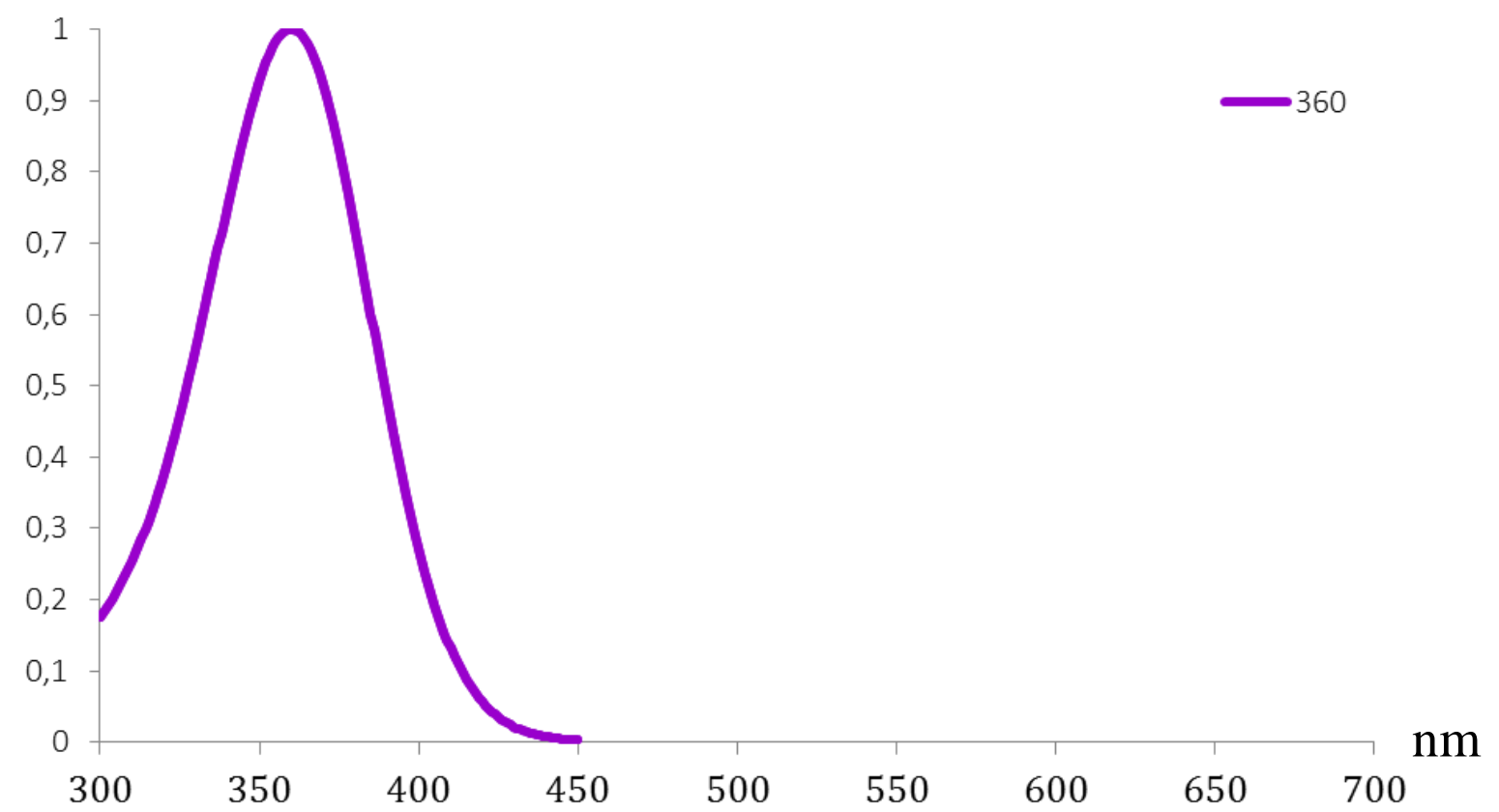

Figura 29. Curva de sensibilidade espectral prevista a partir das sequências de aminoácidos do pigmento SWS1 de serpentes, com pico em $360 \mathrm{~nm}$ para todas as espécies.

\section{Grupo LWS}

O deslocamento espectral do pigmento visual LWS é influenciado por resíduos presentes em cinco sítios críticos, 180, 197, 277, 285 e 308 (Yokoyama \& Radlwimmer, 1999). Nas serpentes estudadas foram observadas quatro diferentes combinações dos sítios envolvidos no deslocamento espectral deste fotopigmento (Figura 30). De acordo com a "regra dos cinco sítios", o perfil SHYTA observado em C. bicarinatus, E. cephalostriata, E. undulata, E. aesculapii, E. miliaris, H. modestus, P. patagoniensis, S. pullatus e T. persimilis, bem como em X. unicolor (FJ497235) e P. regius (FJ497238), 
deve conferir um $\lambda_{\max }$ de $560 \mathrm{~nm}$. A combinação AHYTA, observada em $E$. poecilogyrus e $O$. guibei, pode conferir um deslocamento de até $-7 \mathrm{~nm}$ e um $\lambda_{\max }$ de 553 nm. O perfil AHYAA observado em A. reticulatus, D. petersi, S. mikanii e S. neuwiedi, pode conferir um deslocamento de até $-23 \mathrm{~nm}$ e $\lambda_{\max }$ de $537 \mathrm{~nm}$. E finalmente, o perfil AHFTA, observado apenas em T. dorsatus, pode levar a um deslocamento de $-17 \mathrm{~nm}$, gerando um $\lambda_{\max }$ de $543 \mathrm{~nm}$ (Figura 30).

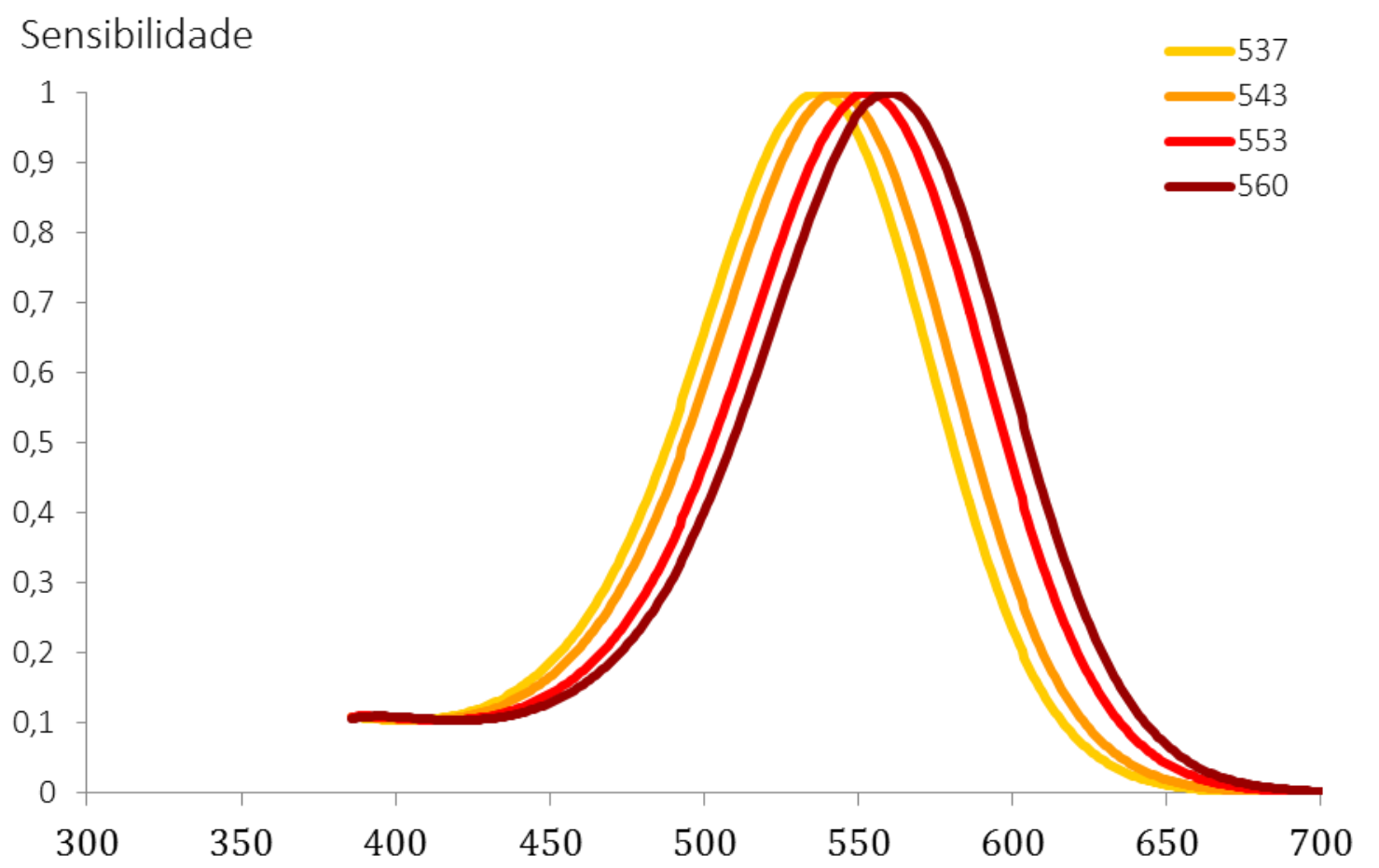

Figura 30. Curvas de sensibilidade espectral previstas a partir das sequências de aminoácidos do pigmento LWS de cones de diferentes espécies de serpentes. A curva de $560 \mathrm{~nm}$ corresponde ao perfil SHYTA, a de $553 \mathrm{~nm}$ ao perfil AHYTA e a de 543 corresponde a combinação AHFTA e a de $537 \mathrm{~nm}$ corresponde ao perfil AHYAA.

Adotando a regra dos "cinco sítios" para o pigmento LWS e a regra dos "sete sítios", para o pigmento Rh1, seis diferentes combinações para estes dois genes foram observadas nas espécies estudadas, conforme ilustrado nas Figuras 31 e 32. As espécies diurnas apresentaram um deslocamento do pico de sensibilidade do Rh1 para o azul, e paralelamente um deslocamento do pigmento LWS para o vermelho (com exceção de $T$. dorsatus e T. strigatus), reduzindo desta forma o grau de sobreposição entre as curvas espectrais dos pigmentos Rh1 e LWS, como pode ser observado na Figura 31. O gene 
SWS1 não apresentou variação de sensibilidade espectral de acordo com a sequência de aminoácidos, e foi considerado um $\lambda_{\max }$ de $360 \mathrm{~nm}$ para todas as espécies.

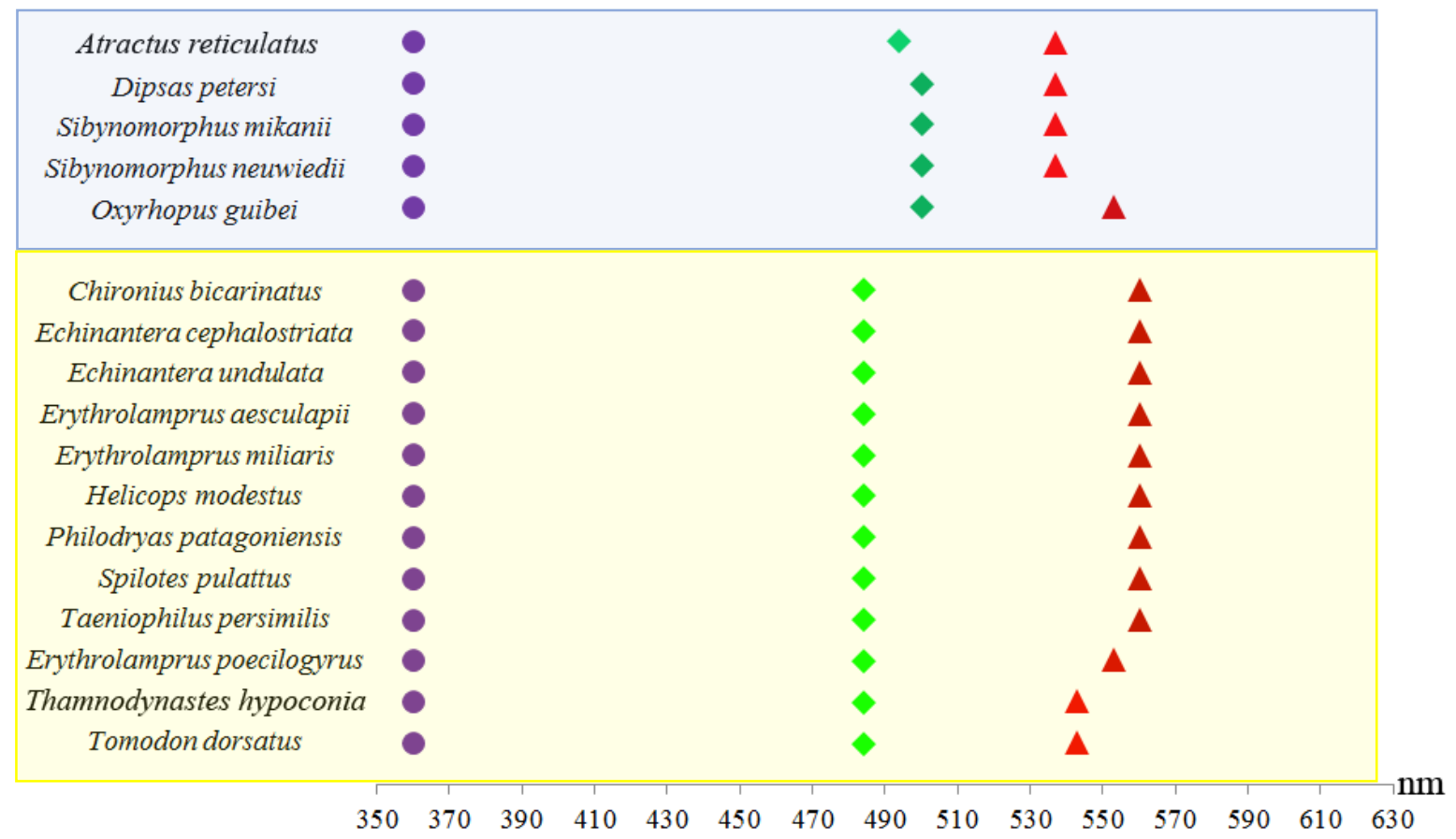

Figura 31. Sensibilidade espectral estimada a partir da sequência de aminoácidos dos pigmentos visuais Rh1 $(\diamond)$, LWS $(\boldsymbol{\Delta})$ e SWS1 $(\bullet)$ de serpentes noturnas (fundo azul) e diurnas (fundo amarelo). Em serpentes diurnas o pigmento Rh1 teve um deslocamento para o azul, enquanto o pigmento LWS apresentou maior deslocamento para o vermelho na maioria das espécies, reduzindo desta forma o grau de sobreposição dos picos de sensibilidade espectral dos dois pigmentos. 


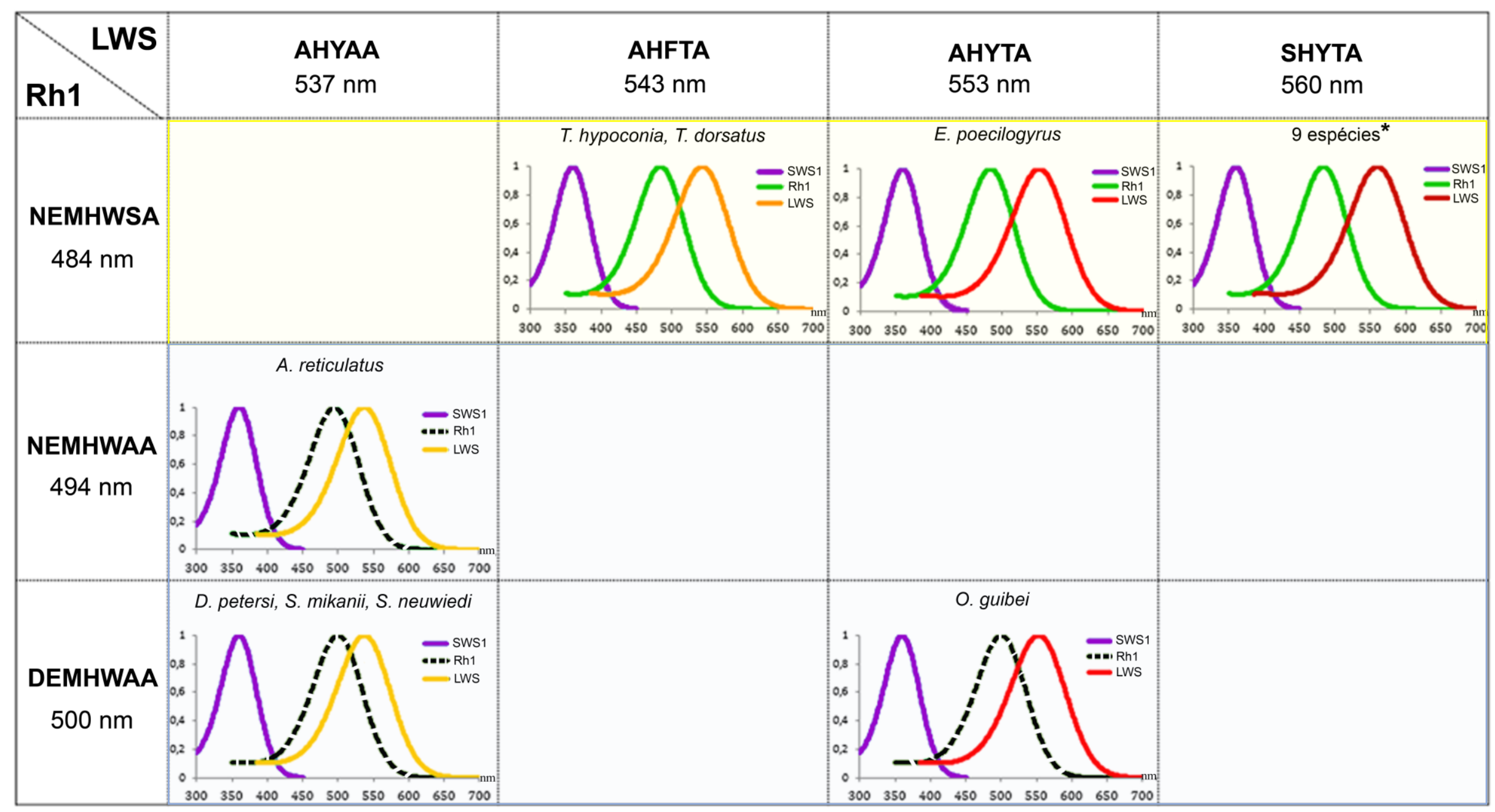

Figura 32. Variações da sensibilidade espectral de serpentes Caenophidia, estimadas a partir das sequências de aminoácidos das opsinas Rh1, LWS e SWS1. Rh1 com três possíveis combinações (NEMHWSA, NEMHWAA e DEMHWAA); LWS com quatro possíveis combinações (AHYAA, AHFTA, AHYTA e SHYTA). O fotopigmento SWS1 de todas as espécies apresentou $\lambda_{\max }$ de $360 \mathrm{~nm}$. Em serpentes diurnas (fundo amarelo) o gene Rh1 é expresso em cones e deve contribuir para a visão de cores diurna. Em serpentes noturnas (fundo azul), o gene Rh1 é expresso em bastonetes (representados pela linha tracejada nos gráficos). 9 espécies*: C. bicarinatus, E. cephalostriata, E. undulata, E. aesculapii, E. miliaris, H. modestus, P. patagoniensis, S. pullatus e T. persimilis. 


\subsection{Análises morfológicas}

\subsubsection{Estrutura das retinas: cortes radiais}

Nos cortes radiais das retinas das serpentes estudadas foi possível observar o mesmo padrão de organização em dez camadas descrito para vertebrados. Diferenças marcantes foram observadas entre as retinas de serpentes de hábitos diurnos e noturnos, especialmente com relação ao tamanho e densidade de fotorreceptores e a espessura da camada nuclear externa (CNE). Nas retinas das serpentes noturnas, A. pantostictus, D. petersi, O. guibei, S. mikanii e S. neuwiedi, foi observada uma grande quantidade de fotorreceptores de pequeno tamanho e a CNE apresentou diversas fileiras sobrepostas de núcleos (Figura 33). Nas retinas das serpentes diurnas, C. bicarinatus, E. undulata, E. aesculapii, E. miliaris, E. poecilogyrus, H. modestus, T. strigatus e T. dorsatus, a CNE apresentou uma única fileira de núcleos, apontando para a baixa densidade de fotorreceptores (Figura 33).

Serpentes do gênero Thamnodynastes são categorizadas na literatura como preferencialmente noturnas (Marques \& Sazima, 2004; Hartman et al., 2009), podendo, entretanto, apresentar também atividade diurna (Torello-Viera, 2014). A retina de Thamnodynastes strigatus apresentou o mesmo padrão encontrado para serpentes diurnas, com apenas uma fileira de núcleos na $\mathrm{CNE}$ e fotorreceptores grandes e em pequeno número e, portanto, as serpentes deste gênero analisadas neste estudo foram classificadas como diurnas, para análises dos resultados obtidos. 

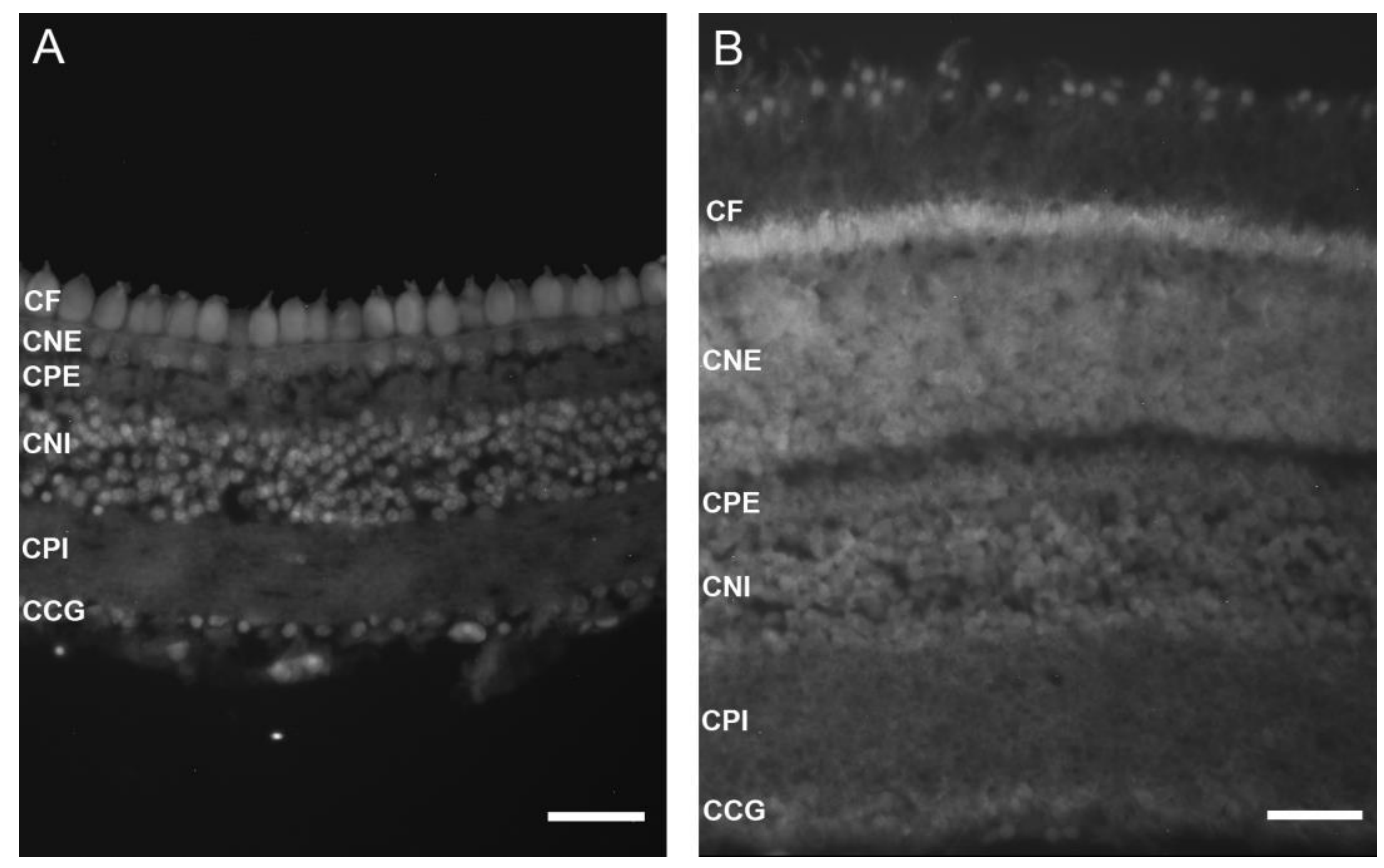

Figura 33. Cortes radiais de retinas da serpente diurna E. miliaris (A) e noturna D. petersi (B) revelados com o marcador para fluorescência DAPI. CF, camada dos fotorreceptores; CNE, camada nuclear externa; CPE, camada plexiforme externa; CNI, camada nuclear interna; CPI, camada plexiforme interna; CCG, camada de células ganglionares. Barras da escala $40 \mu \mathrm{m}$.

As aglutininas WGA (wheat germ aglutinin) e PNA (peanut aglutinin lectin) também marcaram de modo diferenciado as retinas de serpentes diurnas e noturnas (Sameshima et al., 1987). Em espécies noturnas, os segmentos externos de grande quantidade de fotorreceptores foram marcados pelo WGA, e os segmentos externos de uma pequena quantidade de fotorreceptores foram marcados pelo PNA, indicando a predominância de bastonetes nas retinas de serpentes noturnas (Figura 34). Nas retinas de serpentes diurnas, nenhuma marcação foi observada nos cortes incubados com WGA. A marcação com PNA, por sua vez, revelou os segmentos externos de todos os fotorreceptores, apontando assim para a ausência de bastonetes e presença de apenas cones nas retinas das espécies diurnas, incluindo T. strigatus. Todos os fotorreceptores observados nas retinas de serpentes diurnas apresentaram segmento externo curto e elipsóide oval, com exceção do membro acessório dos cones duplos. Nas espécies noturnas, os cones apresentaram segmento interno grande comparado aos dos bastonetes e um segmento externo mais curto (Figura 34). 

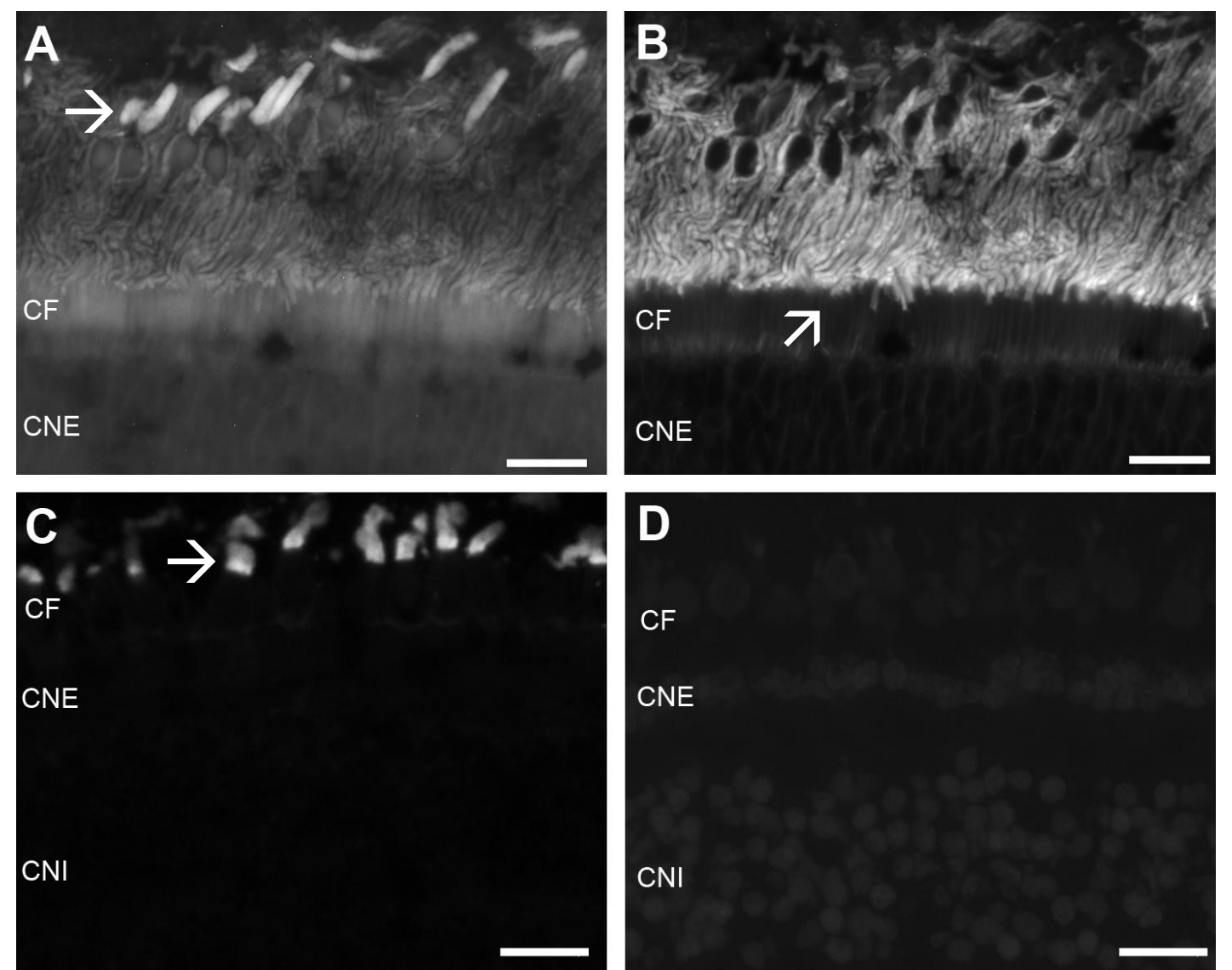

Figura 34. Acima, corte radial de retina da serpente noturna D. petersi, marcada com PNA (A) e com WGA (B), e abaixo, corte radial de retina da serpente diurna E. miliaris, marcada com PNA (C) e com WGA (D). As setas nas figuras A e C apontam para a marcação do segmento externo de cones. Na figura $\mathrm{B}$, a seta aponta para a região dos segmentos externos dos bastonetes marcados pelo WGA. CF, camada de fotorreceptores; CNE, camada nuclear externa; CNI, camada nuclear interna. Barras da escala $40 \mu \mathrm{m}$.

Os anticorpos JH455 e AB5407, produzidos em coelhos contra opsinas sensíveis a comprimentos de conda curtos de cone $\mathrm{S}$ de humanos (Nathan et al., 1986), marcaram os segmentos externos de pequena quantidade de cones simples pequenos nas retinas de todas as espécies analisadas, diurnas e noturnas (Figura 35). Os anticorpos JH492 e AB5405, produzidos em coelho contra opsinas sensíveis aos comprimentos de onda longos e médios de cones L/M de humanos (Nathan et al., 1986), marcaram os segmentos externos de grande quantidade de cones simples grandes e do membro principal e acessório de cones duplos, nas retinas das espécies diurnas (Figura 35). Nas espécies noturnas os anticorpos contra cones L/M marcaram a maior parte dos cones, todos eles do tipo simples e grande. Nenhum cone duplo foi observado em retinas de 
serpentes noturnas. Ambos conjuntos de anticorpos foram utilizados em retinas planas

para marcação e quantificação destes dois grupos de fotorreceptores.

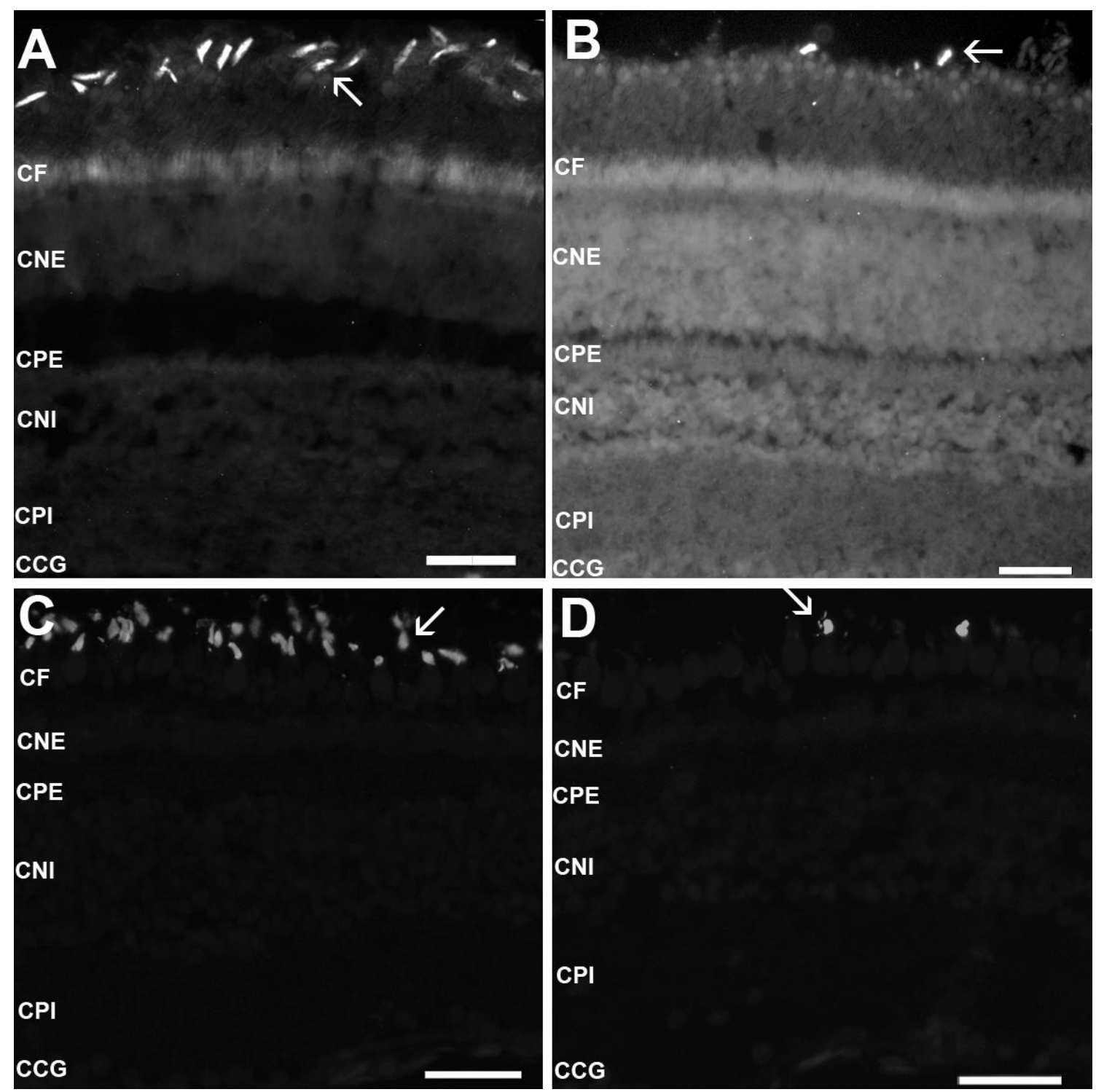

Figura 35. Cortes radiais de retinas marcadas com os anticorpos JH492 anti-opsinas de cone L/M e JH455, anti-opsinas de cone S. Acima, retinas de serpente noturna $D$. petersi marcada com JH492 (A), revelando os segmentos externos de grande quantidade de cones, e marcada com JH455 (B), revelando os segmentos externos de pequeno número de cones. Abaixo, retina da serpente diurna $H$. modestus, com grande quantidade de cones simples e duplos marcados pelo JH492 (C) e pequena quantidade de cones simples marcados pelo JH455 (D). As setas em todas as imagens apontam para os segmentos externos dos fotorreceptores imunomarcados. CF, camada dos fotorreceptores; CNE, camada nuclear externa; CPE, camada plexiforme externa; CNI, camada nuclear interna; CPI, camada plexiforme interna; CCG, camada de células ganglionares. Barras de escala $40 \mu \mathrm{m}$. 


\subsubsection{Densidade e topografia de neurônios}

\section{População de células da Camada de Células Ganglionares (CCG)}

A amostragem de células da CCG foi feita a partir da contagem dos corpos celulares de neurônios (células ganglionares e amácrinas deslocadas), corados pela técnica de Nissl. Células da glia foram diferenciadas devido ao seu tamanho reduzido, perfil arredondado e coloração escura e não foram incluídas nas contagens (Figura 36). A densidade de células foi estimada em 35 retinas de 16 diferentes espécies de serpentes, sendo 13 retinas de serpentes de hábitos noturnos e 22 de serpentes de hábitos diurnos. Os parâmetros estereológicos utilizados para amostragem de células da CCG de cada retina estão apresentados no Anexo 7. Os reultados obtidos, incluindo a densidade média de células, a população total, a densidade máxima e os valores estimados do poder de resolução espacial de cada retina estão apresentados na Tabela 5. Os gráficos apresentados na Figura 37 mostram os valores de densidade média e população total de células da CCG de cada retina, as áreas das retinas $\mathrm{em} \mathrm{mm}^{2}$ e o poder estimado de resolução espacial em ciclos por grau (cpg).

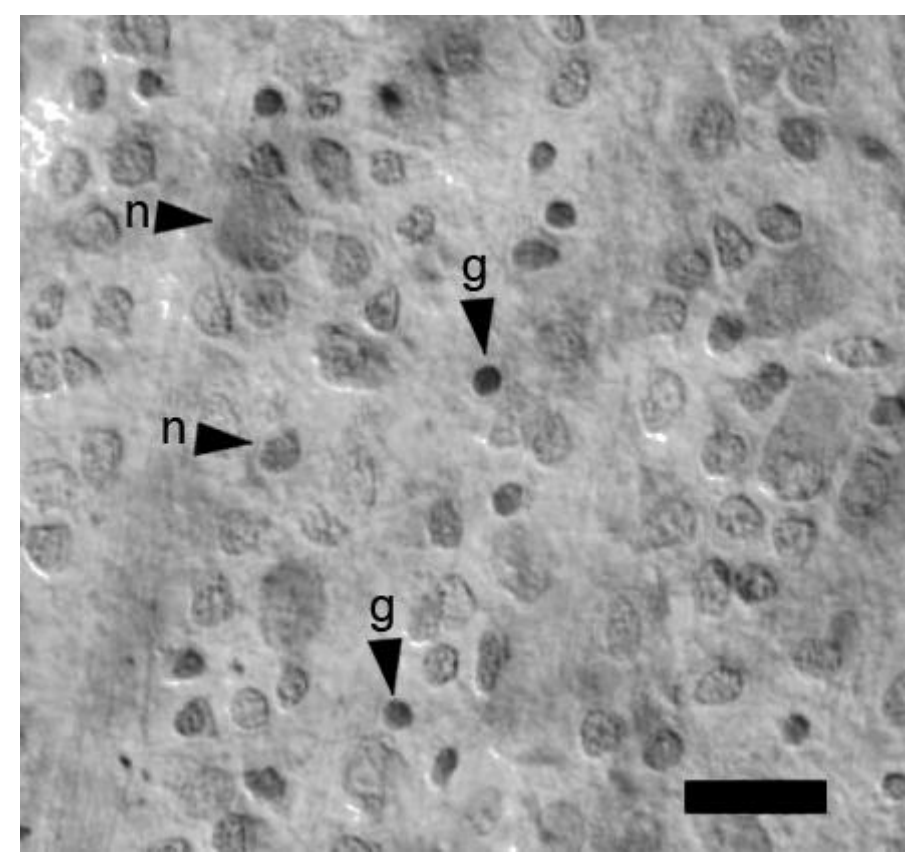

Figura 36. Imagem de campo amostrado de retina de Echinantera undulata, corada pela técnica de Nissl, com foco na camada de células ganglionares (CCG); n, neurônios; g, células da glia. Barra de escala $20 \mu \mathrm{m}$. 
Tabela 5. Análises estereológicas da população de células da CCG e parâmetros anatômicos utilizados para estimar o poder de resolução espacial.

\begin{tabular}{|c|c|c|c|c|c|c|c|}
\hline Espécies & Número total de células & $\mathrm{CE}$ & $\begin{array}{l}\text { Dens Média } \\
\left(\text { células } / \mathrm{mm}^{2} \text { ) }\right.\end{array}$ & $\begin{array}{l}\text { Comprimento axial } \\
\text { do olho }(\mathrm{mm})^{*}\end{array}$ & $\begin{array}{l}\text { PND } \\
(\mathrm{mm})\end{array}$ & $\begin{array}{l}\text { Dens Máx } \\
\text { (células/mm²) }\end{array}$ & $\begin{array}{c}\text { Resolução } \\
\text { Espacial (cpg) }\end{array}$ \\
\hline \multicolumn{8}{|l|}{ Noturnas } \\
\hline \multicolumn{8}{|l|}{ A. pantostictus } \\
\hline \multicolumn{8}{|l|}{ A. reticulatus } \\
\hline \#1 & 25.215 & 0,01 & $9.304 \pm 1650$ & 1,8 & 0,94 & 11.786 & 0,95 \\
\hline$\# 2$ & 27.479 & 0,01 & $11.355 \pm 1.662$ & 1,6 & 0,8 & 16.497 & 1 \\
\hline Média $\pm d p$ & $26.347 \pm 1.601$ & & $10.330 \pm 1.450$ & & & & $1 \pm 0,1$ \\
\hline \multicolumn{8}{|l|}{ D. albifrons } \\
\hline \#1 & 121.931 & 0,01 & $6.677 \pm 1.107$ & 3,5 & 1,82 & 8.795 & 1,6 \\
\hline $\begin{array}{c}\text { D. petersi } \\
\# 1\end{array}$ & 175.154 & 0,01 & $6.222 \pm 968$ & 4,9 & 2,55 & 8.798 & 2,24 \\
\hline \multicolumn{8}{|l|}{ O. guibei } \\
\hline$\# 1$ & 75.806 & 0,01 & $8.470 \pm 1.655$ & 3,5 & 1,8 & 12.123 & 1,9 \\
\hline \#2 & 61.205 & 0,01 & $8.107 \pm 1.329$ & 3,5 & 2,1 & 10.960 & 1,8 \\
\hline \#3 & 66.004 & 0,01 & $5.930 \pm 1.149$ & 2,9 & 1,5 & 8.143 & 1,3 \\
\hline Média $\pm d p$ & $67.672 \pm 7442$ & & $7.502 \pm 1.373$ & & & $10.409 \pm 2.046$ & $1,7 \pm 0,3$ \\
\hline \multicolumn{8}{|l|}{ S. mikanii } \\
\hline \#1 & 58.632 & 0,01 & $7.839 \pm 1.856$ & 2,5 & 1,3 & 11.771 & 1,4 \\
\hline \#2 & 54.709 & 0,01 & $8.455 \pm 1.723$ & 2,3 & 1,2 & 11.501 & 1,2 \\
\hline \#3 & 67.733 & 0,01 & $8.457 \pm 750$ & 2,5 & 1,3 & 9.715 & 1,2 \\
\hline Média \pm dp & $60.358 \pm 6.681$ & & $8.251 \pm 357$ & & & $10.996 \pm 1.117$ & $1,3 \pm 0,1$ \\
\hline \multicolumn{8}{|l|}{ S. neuwiedi } \\
\hline \#1 & 118.716 & 0,01 & $7152 \pm 874$ & 3,5 & 1,8 & 8.824 & 1,6 \\
\hline \#2 & 77.298 & 0,01 & $5987 \pm 1200$ & 3,7 & 1,9 & 9.531 & 1,8 \\
\hline Média \pm dp & $98.007 \pm 29.287$ & & $5.670 \pm 823$ & & & $9.178 \pm 500$ & $1,7 \pm 0,1$ \\
\hline \multicolumn{8}{|l|}{ Diurnas } \\
\hline \multicolumn{8}{|l|}{ C. bicarinatus } \\
\hline \#1 & 512.527 & 0,01 & $8.742 \pm 1.601$ & 5,5 & 2,86 & 11.549 & 2,9 \\
\hline \#2 & 429.970 & 0,01 & $6.924 \pm 1.505$ & 6 & 3,12 & 12.831 & 3,3 \\
\hline Média \pm dp & $471.249 \pm 58.376$ & & $7.833 \pm 1.285$ & & \pm & $12.190 \pm 907$ & $3,1 \pm 0,3$ \\
\hline \multicolumn{8}{|l|}{ E. undulata } \\
\hline \#1 & 214.522 & 0,01 & $8.442 \pm 2.330$ & 4 & 2,1 & 14.214 & 2,3 \\
\hline$\# 2$ & 241.839 & 0,01 & $9.851 \pm 3.502$ & 3,5 & 1,8 & 16.316 & 2,2 \\
\hline Média $\pm d p$ & $228.181 \pm 19.317$ & & $9.147 \pm 996$ & & & $15.265 \pm 1.487$ & $2,25 \pm 0,07$ \\
\hline \multicolumn{8}{|l|}{ E. aesculapii } \\
\hline \#1 & 194.026 & 0,01 & $11.100 \pm 2.252$ & 3,5 & 1,8 & 15.966 & 2,2 \\
\hline$\# 2$ & 270.577 & 0,01 & $8.175 \pm 2.285$ & 4,5 & 2,3 & 13.029 & 2,5 \\
\hline Média $\pm \mathrm{dp}$ & $232.301 \pm 54.130$ & & $9.637 \pm 2.069$ & & & $14.497 \pm 2.076$ & $2,3 \pm 0,2$ \\
\hline \multicolumn{8}{|l|}{ E. miliaris } \\
\hline$\# 1$ & 210.164 & 0,01 & $10.953 \pm 3.432$ & 3,2 & 1,7 & 19.908 & 2,1 \\
\hline \#2 & 148.715 & 0,01 & $8.378 \pm 1.633$ & 3,1 & 1,6 & 13.562 & 1,8 \\
\hline$\# 3$ & 172.525 & 0,01 & $7.842 \pm 2.034$ & 4 & 2,1 & 12.281 & 2,2 \\
\hline Média \pm dp & $177.135 \pm 30.983$ & & $9.061 \pm 1.669$ & & & $14.917 \pm 3.515$ & $2 \pm 0,2$ \\
\hline E. poecilogyrus & & & & & & & \\
\hline$\# 1$ & 166.953 & 0,01 & $9,353 \pm 2.792$ & 3,5 & 1,8 & 14.095 & 2 \\
\hline \#2 & 110.153 & 0,01 & $7.016 \pm 2.258$ & 3 & 1,6 & 13.381 & 1,7 \\
\hline Média $\pm d p$ & $138.553 \pm 40.164$ & & $8,185 \pm 1.653$ & & & $13.738 \pm 505$ & $1,9 \pm 0,2$ \\
\hline H. modestus & & & & & & & \\
\hline \#1 & 82.172 & 0,01 & $9.997 \pm 2.080$ & 2,1 & 0,95 & 14.303 & 1,2 \\
\hline \#2 & 97.731 & 0,01 & $7.021 \pm 1.157$ & 3 & 1,4 & 9.890 & 1,5 \\
\hline \#3 & 86.790 & 0,01 & $11.792 \pm 2.258$ & 2,3 & 1 & 16.079 & 1,4 \\
\hline Média \pm dp & $88.898 \pm 7.991$ & & $9.603 \pm 2.410$ & & & $13.424 \pm 3.187$ & $1,4 \pm 0,1$ \\
\hline S. pullatus & & & & & & & \\
\hline \#1 & 627.447 & 0,01 & $7.159 \pm 1.722$ & 7,6 & 3,9 & 12.098 & 4 \\
\hline \#2 & 614.553 & 0,01 & $7.025 \pm 1.355$ & 7 & 3,6 & 10.815 & 3,6 \\
\hline Média $\pm d p$ & $621.000 \pm 9.118$ & & $7.142 \pm 165$ & & & $11.456 \pm 907$ & $3,8 \pm 0,4$ \\
\hline T. strigatus & & & & & & & \\
\hline \#1 & 134.502 & 0,01 & 12.306 & 3 & 1,6 & 16.760 & 1,9 \\
\hline$\# 2$ & 206.251 & 0,01 & 7.044 & 4 & 2,1 & 11.460 & 2,1 \\
\hline \#3 & 235.824 & 0,01 & 13.293 & 3 & 1,6 & 17.175 & 1,9 \\
\hline Média \pm dp & $192.192 \pm 52.104$ & & $10.881 \pm 3.359$ & & & $15.132 \pm 3187$ & $2 \pm 0,12$ \\
\hline T. dorsatus & & & & & & & \\
\hline \#1 & 276.402 & 0,01 & 14.366 & 3,8 & 1,97 & 19.811 & 2,6 \\
\hline \#2 & 241.762 & 0,01 & 12.112 & 4 & 2,1 & 16.523 & 2,5 \\
\hline$\# 3$ & 220.798 & 0,01 & 11.652 & 4 & 2,1 & 16.168 & 2,5 \\
\hline Média $\pm d p$ & $246.321 \pm 28.081$ & & $12.710 \pm 1.453$ & & & $17.501 \pm 2008$ & $2,5 \pm 0,07$ \\
\hline
\end{tabular}

CE, Coeficiente de erro de Schaeffer; PND, distância posterior nodal; cpg, ciclos por grau;

dp, desvio padrão. *Distância entre o polo anterior e o polo posterior do olho. 

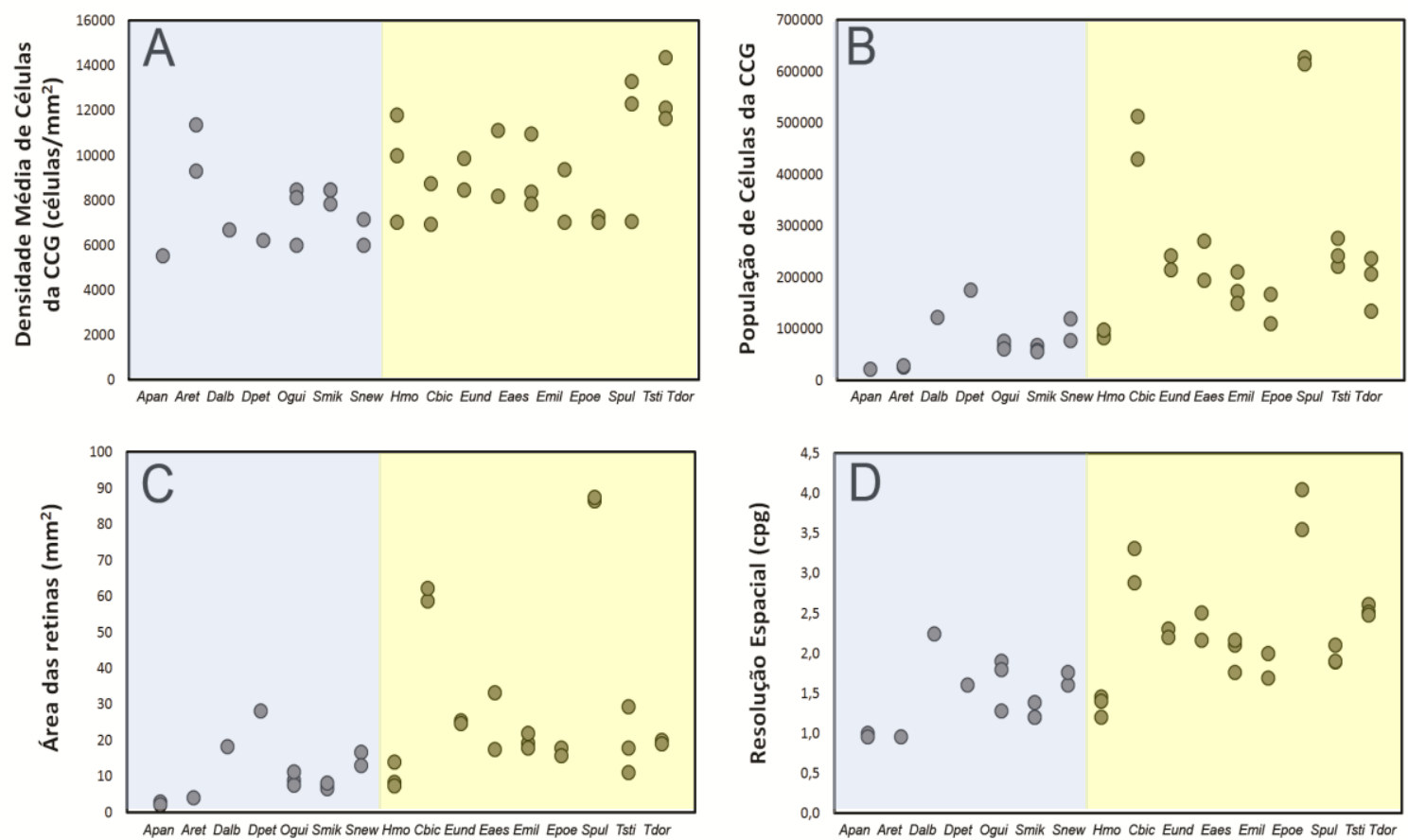

Figura 37. Variações da densidade média e do número total de células da CCG (A, B), das áreas das retinas (C) e dos valores estimados do poder de resolução espacial (D), das retinas de serpentes noturnas (em azul) e diurnas (em amarelo): Apan, Atractus pantostictus; Aret, A. reticulatus; Dalb, Dipsas albifrons; Dpet, D. petersi; Ogui, Oxyrhopus guibei; Smik, Sibynomorphus mikanii; Snew, S. neuwiedi; Hmo, Helicops modestus; Cbic, Chironius bicarinatus; Eund, Echinantera undulata; Eaes, Erythrolamprus aesculapii; Emil, E. miliaris; Epoe, E. poecilogyrus; Spul, Spilotes pullatus; Tstri, Thamnodynates strigatus; Tdor, Tomodon dorsatus.

As análises dos valores de densidades média e população total de células da CCG, bem como da estimativa do poder de resolução espacial, revelaram diferenças significativas entre os grupos de serpentes diurnas e noturnas. A média da população de células da CCG foi de $73.134 \pm 43.567$ células em retinas de serpentes noturnas e de $239.500 \pm 161.651$ células em retinas de serpentes diurnas $\left(\mathrm{t}_{(27,19)}=-4,646\right.$ e $\left.p=0,000\right)$. A média das densidades médias foi de $7.653 \pm 1.636$ células $/ \mathrm{mm}^{2}$ nas espécies noturnas e $9.575 \pm 2.301$ células $/ \mathrm{mm}^{2}$ nas diurnas $\left(\mathrm{t}_{(31,7)}=2,876\right.$ e $\left.p=0,007\right)$. A análise da distribuição dos dados nos grupos, entretanto, indicou a presença de outliers que poderiam estar influenciando no resultado da análise. Por essa razão, para garantir a homocedasticidade dos dados e a confiabilidade do teste estatístico para a variável de população total de células, uma nova comparação foi feita, com a exclusão das duas 
retinas de $S$. pullatus, do grupo de serpentes diurnas, com valores de população total de células da CCG muito elevados. A média da população total de células da CCG sem os outliers foi de $203.167 \pm 113.136$ células, e o resultado confirmou a presença de diferença significativa entre os dois grupos de serpentes $\left(t_{(28,05)}=4,73\right.$ e $\left.p=0,000\right)$. As médias dos valores de resolução espacial foram de 1,45 $\pm 0,4$ cpg em serpentes noturnas, e de $2,3 \pm 0,7 \mathrm{cpg}$ em diurnas $\left(\mathrm{t}_{(33,00)}=-4,484\right.$ e $\left.p=0,000\right)$.

Análises comparativas das áreas das retinas foram realizadas considerando as retinas analisadas para estudo de células da CCG e de fotorreceptores, e apenas uma retina de cada indivíduo foi utilizada na comparação entre os grupos de serpentes diurnas e noturnas. A média das áreas de 20 retinas de serpentes noturnas foi de 12,4 $\pm 9,5 \mathrm{~mm}^{2}$, e de 43 retinas de serpentes diurnas foi de $33 \pm 24,4 \mathrm{~mm}^{2}$, resultando em uma diferença significativa entre os dois grupos $\left(\mathrm{t}_{(59,80)}=-4,782 p=0,000\right)$. Para confirmar a confiabilidade do teste estatístico uma nova análise foi feita, com a exclusão de quatro outliers do grupo de serpentes diurnas (duas retinas de C. bicarinatus e duas de S. pullatus). A média das áreas das retinas de serpentes diurnas, sem os outliers, foi de $26,6 \pm 13,8 \mathrm{~mm}^{2}$, e foi verificada novamente a diferença significativa entre os dois grupos $\left(\mathrm{t}_{(51,79)}=-4,622, p=0,000\right)$.

\section{População de fotorreceptores}

A população de fotorreceptores foi estimada em 71 retinas de 17 diferentes espécies, a partir da contagem dos segmentos internos marcados de forma inespecífica na imunohistoquímica ou pela coloração de Nissl (Figura 38). Dentre as retinas quantificadas, 14 eram de serpentes de hábitos noturnos (6 diferentes espécies) e 57 de serpentes de hábitos diurnos (11 diferentes espécies) (Tabelas 6 e 7). Os parâmetros 
Anexo 8.
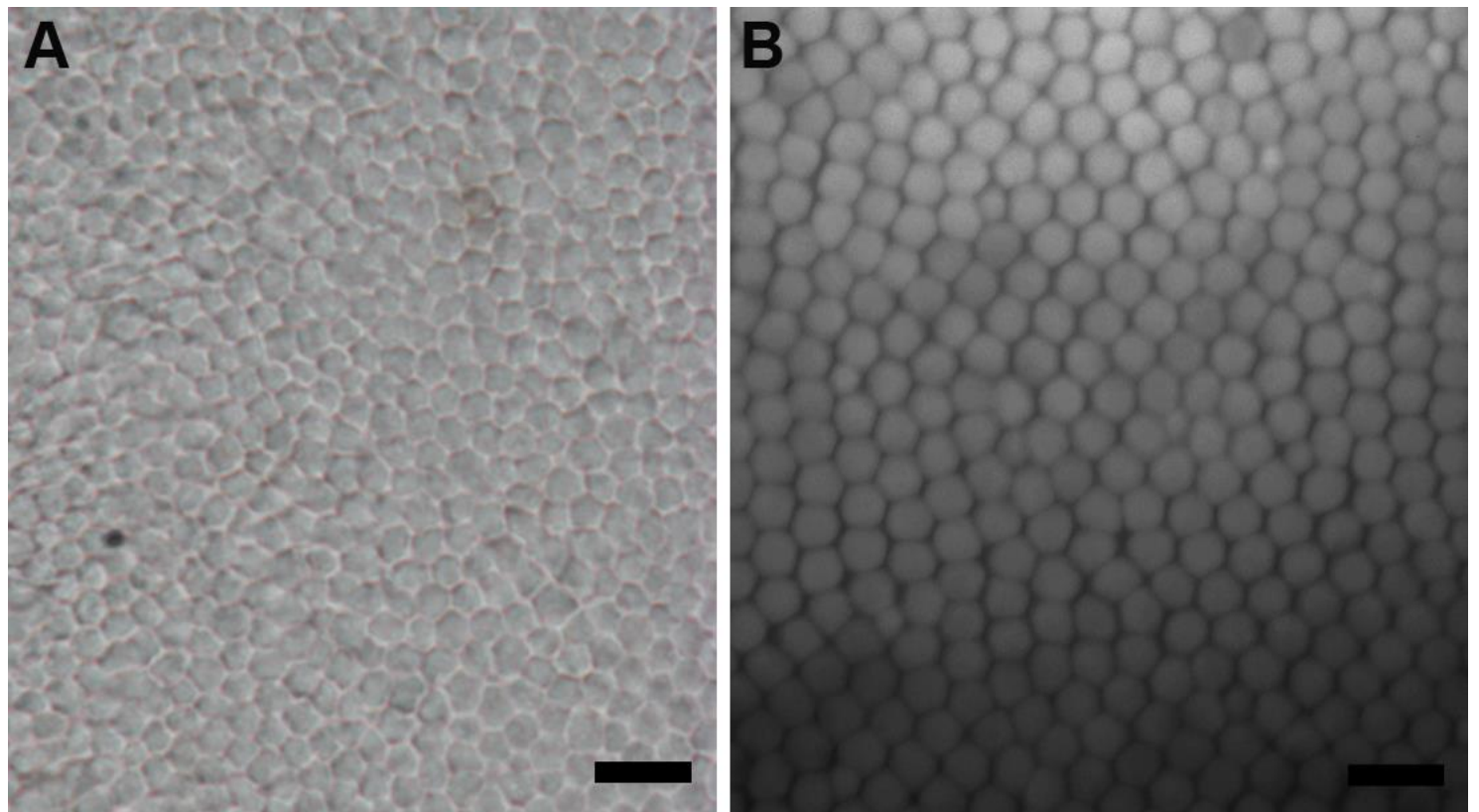

Figura 38. Campos amostrados de retinas aplanadas sobre lâmina, com foco na região do segmento interno de fotorreceptores, imunomarcados de forma inespecífica pelos diferentes anticorpos primários utilizados (A e B). A, retina de serpente noturna $D$. petersi, com alta densidade de fotorreceptores. B, retina da serpente diurna $C$. bicarinatus, com fotorreceptores maiores e em menor número. Barras de escala $20 \mu \mathrm{m}$.

Nas retinas de todas as espécies diurnas foi observada uma baixa densidade de células, que variou entre aproximadamente 7.000 células $/ \mathrm{mm}^{2}$ na espécie arborícola $C$. bicarinatus, até cerca de 17.500 células $/ \mathrm{mm}^{2}$ na terrícola E. poecilogyrus. A densidade média de fotorreceptores em retinas de serpentes noturnas foi mais alta e teve uma maior variação, com cerca de 38.000 células $/ \mathrm{mm}^{2}$ na serpente fossorial A. pantostictus, até mais de 160.000 células $/ \mathrm{mm}^{2}$ na serpente arborícola $D$. bucephala. As análises estatísticas revelaram diferenças significativas das densidades de fotorreceptores dos grupos de serpentes diurnas e noturnas. A média das densidades médias dos fotorreceptores foi de $82.042 \pm 37.945$ celulas $/ \mathrm{mm}^{2}$ em retinas de serpentes noturnas e de $11.290 \pm 2.810$ celulas $/ \mathrm{mm}^{2}$ nas retinas das diurnas $\left(\mathrm{t}_{(10,02)}=6,181, p=0,000\right)$. A média da população total de fotorreceptores foi significativamente maior nas serpentes 
noturnas, com 1.906.775 \pm 1.785 .374 células, do que nas diurnas, com $349.266 \pm$ 238.371 células $\left(\mathrm{t}_{(10,07)}=2,888, p=0,016\right)$.

Em algumas retinas das espécies noturnas foi possível distinguir e quantificar as populações de cones e de bastonetes (Figura 39). Nestes casos, foi observada uma semelhança entre a densidade média de cones dos dois grupos de serpentes, diurnas e noturnas; o valor mais baixo da densidade de cones foi encontrado na retina de $D$. bucephala $\left(5.112 \pm 2.196\right.$ células $\left./ \mathrm{mm}^{2}\right)$, e o mais alto na retina de A. reticulatus $(16.983$ \pm 2.199 células $/ \mathrm{mm}^{2}$ ). Os valores de densidade média e de população total de fotorreceptores de cada retina analisada estão descritos nas Tabelas 6 (serpentes diurnas) e 7 (serpentes noturnas).
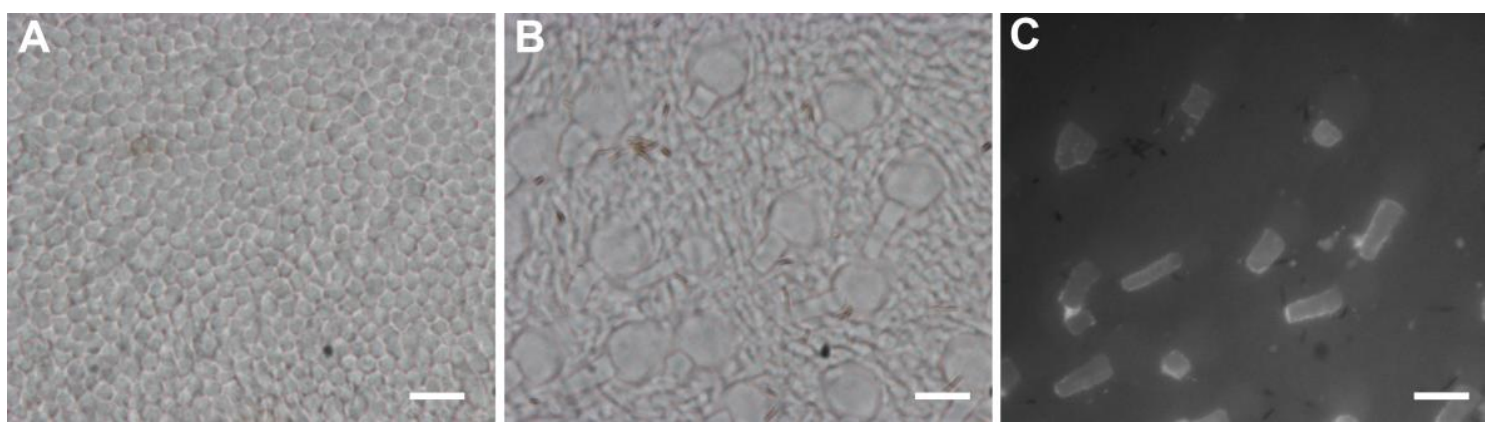

Figura 39. Imagens de um mesmo campo amostrado de retina da serpente noturna Dipsas bucephala, imunomarcada com anticorpo anti-opsinas L/M. Com o ajuste do foco do microscópio é possível visualizar os segmentos internos de bastonetes (A) ou de cones (B). Em $\mathrm{C}$, os segmentos externos de cones L/M, marcados pelo anticorpo JH492, e revelados pela molécula fluorescente TRITC. Barras de escala $20 \mu \mathrm{m}$. 
Tabela 6. Análises estereológicas da população de fotorreceptores de serpentes diurnas.

\begin{tabular}{|c|c|c|c|c|}
\hline Espécies & Retinas & Número total de células & $\mathbf{C E}$ & Dens Média (células/mm²) \\
\hline \multirow{7}{*}{ Chironius bicarinatus } & $\# 1$ & 528.067 & 0,007 & $9.474 \pm 1.534$ \\
\hline & $\# 2$ & 696.047 & 0,006 & $10.527 \pm 2.247$ \\
\hline & \#3 & 837.954 & 0,007 & $6.989 \pm 1.758$ \\
\hline & \#4 & 733.503 & 0,006 & $12.307 \pm 2.368$ \\
\hline & \#5 & 716.047 & 0,007 & $12.213 \pm 2.371$ \\
\hline & \#6 & 712.248 & 0,006 & $8.873 \pm 2.303$ \\
\hline & $\# 7$ & 673.551 & 0,007 & $12.165 \pm 2.771$ \\
\hline Média \pm dp & & $699.631 \pm 92.047$ & & $10.364 \pm 2.036$ \\
\hline \multirow{3}{*}{ Echinantera undulata } & $\# 1$ & 266.211 & 0,01 & $11.675 \pm 3.177$ \\
\hline & $\# 2$ & 295.048 & 0,007 & $11.611 \pm 2.615$ \\
\hline & \#3 & 304.190 & 0,007 & $12.390 \pm 3.394$ \\
\hline Média \pm dp & & $288.483 \pm 19.822$ & & $11.893 \pm 432$ \\
\hline \multirow{6}{*}{ Erythrolamprus aesculapii } & $\# 1$ & 267.343 & 0,01 & $13.931 \pm 2.847$ \\
\hline & $\# 2$ & 363.106 & 0,006 & $10.970 \pm 2.942$ \\
\hline & \#3 & 326.320 & 0,01 & $11.879 \pm 2.393$ \\
\hline & $\# 4$ & 419.831 & 0,005 & $12.982 \pm 3.405$ \\
\hline & $\# 5$ & 479.112 & 0,01 & $13.470 \pm 3.717$ \\
\hline & \#6 & 241.018 & 0,01 & $7.072 \pm 1.973$ \\
\hline Média \pm dp & & $349.455 \pm 90.539$ & & $11.717 \pm 2.519$ \\
\hline \multirow{5}{*}{ Erythrolamprus miliaris } & $\# 1$ & 276.578 & 0,01 & $11.229 \pm 3.102$ \\
\hline & $\# 2$ & 274.819 & 0,01 & $15.483 \pm 2.864$ \\
\hline & \#3 & 381.272 & 0,01 & $17.331 \pm 4.842$ \\
\hline & $\# 4$ & 244.917 & 0,01 & $9.597 \pm 2.827$ \\
\hline & \#5 & 351.661 & 0,01 & $10.105 \pm 2.661$ \\
\hline Média \pm dp & & $305.849 \pm 57.705$ & & $12.749 \pm 3.453$ \\
\hline \multirow{7}{*}{ Erythrolamprus poecilogyrus } & \#1 & 291.950 & 0,006 & $14.111 \pm 2966$ \\
\hline & $\# 2$ & 242.582 & 0,01 & $11.764 \pm 2410$ \\
\hline & \#3 & 226.121 & 0,007 & $12.668 \pm 2999$ \\
\hline & \#4 & 243.197 & 0,01 & $9.095 \pm 3095$ \\
\hline & $\# 5$ & 223.767 & 0,01 & $9.037 \pm 2391$ \\
\hline & \#6 & 258.649 & 0,05 & $9.746 \pm 3256$ \\
\hline & $\# 7$ & 274.374 & 0,009 & $17.476 \pm 3931$ \\
\hline Média \pm dp & & $251.520 \pm 25.074$ & & $11.985 \pm 3089$ \\
\hline \multirow{8}{*}{ Helicops modestus } & $\# 1$ & 96.060 & 0,01 & $8.886 \pm 2.472$ \\
\hline & $\# 2$ & 116.443 & 0,01 & $14.166 \pm 3.958$ \\
\hline & \#3 & 157.340 & 0,008 & $11.303 \pm 3.462$ \\
\hline & \#4 & 113.283 & 0,01 & $11.306 \pm 3.148$ \\
\hline & $\# 5$ & 107.126 & 0,01 & $14.555 \pm 4.797$ \\
\hline & \#6 & 108.677 & 0,01 & $9.677 \pm 3.334$ \\
\hline & \#7 & 98.233 & 0,01 & $10.759 \pm 3.677$ \\
\hline & $\# 8$ & 123.828 & 0,01 & $10.987 \pm 3.657$ \\
\hline Média \pm dp & & $115.124 \pm 19.337$ & & $11.455 \pm 1.981$ \\
\hline \multirow{4}{*}{ Spilotes pullatus } & $\# 1$ & 1.145 .816 & 0,01 & $13.256 \pm 1.982$ \\
\hline & $\# 2$ & 840.560 & 0,01 & $9.775 \pm 1.662$ \\
\hline & \#3 & 901.683 & 0,01 & $9.614 \pm 1.909$ \\
\hline & \#4 & 989.215 & 0,01 & $11.308 \pm 1.941$ \\
\hline Média \pm dp & & $969.318 \pm 132.539$ & & $10.988 \pm 1.694$ \\
\hline \multirow{5}{*}{ Thamnodynates strigatus } & $\# 1$ & 211.853 & 0,01 & $12.404 \pm 1.581$ \\
\hline & $\# 2$ & 185.672 & 0,01 & $16.987 \pm 2.832$ \\
\hline & \#3 & 264.003 & 0,01 & $9.017 \pm 1.778$ \\
\hline & \#4 & 244.362 & 0,01 & $13.774 \pm 3.488$ \\
\hline & $\# 5$ & 263.570 & 0,01 & $7.999 \pm 2.304$ \\
\hline Média \pm dp & & $233.892 \pm 34.307$ & & $12.036 \pm 3.643$ \\
\hline Thamnodynates hypoconia & $\# 1$ & 255.403 & 0,01 & $10.323 \pm 2.186$ \\
\hline Thamnodynates natererii & $\# 1$ & 183.859 & 0,01 & $13.420 \pm 2.397$ \\
\hline \multirow{10}{*}{ Tomodon dorsatus } & $\# 1$ & 214.465 & 0,01 & $8.554 \pm 1.166$ \\
\hline & $\# 2$ & 310.419 & 0,01 & $7.724 \pm 1.325$ \\
\hline & \#3 & 192.742 & 0,01 & $8.659 \pm 2.544$ \\
\hline & $\# 4$ & 303.623 & 0,01 & $13.070 \pm 1.635$ \\
\hline & \#5 & 292.513 & 0,01 & $8.755 \pm 1.350$ \\
\hline & \#6 & 250.454 & 0,01 & $10.908 \pm 2.219$ \\
\hline & $\# 7$ & 267.726 & 0,01 & $13.413 \pm 2.049$ \\
\hline & $\# 8$ & 257.298 & 0,006 & $13.578 \pm 2.005$ \\
\hline & $\# 9$ & 350.797 & 0,01 & $13.338 \pm 4.010$ \\
\hline & $\# 10$ & 295.894 & 0,01 & $11.208 \pm 2.299$ \\
\hline Média \pm dp & & $273.593 \pm 47.072$ & & $10.941 \pm 2.322$ \\
\hline
\end{tabular}

CE, Coeficiente de erro de Schaeffer; dp, desvio padrão. 
Tabela 7. Análises estereológicas da população de fotorreceptores (bastonetes e cones) de serpentes de hábitos noturnos.

\begin{tabular}{|c|c|c|c|c|c|c|c|c|c|}
\hline Espécies & $\begin{array}{l}\text { Número total de } \\
\text { células }\end{array}$ & $\mathbf{C E}$ & $\begin{array}{l}\text { Dens Média } \\
\text { (células/mm²) }\end{array}$ & Total de bastonetes & $\mathbf{C E}$ & $\begin{array}{c}\text { Dens Média de } \\
\text { Bastonetes } \\
\text { (células/mm²) }\end{array}$ & Total de Cones & $\mathbf{C E}$ & $\begin{array}{c}\text { Dens Média de } \\
\text { Cones } \\
\text { (células } / \mathbf{m m}^{2} \text { ) }\end{array}$ \\
\hline \multicolumn{10}{|l|}{ A. pantostictus } \\
\hline$\# 1$ & - & - & - & - & - & - & 44.772 & 0,01 & $15.176 \pm 2.170$ \\
\hline$\# 2$ & 143.439 & 0,01 & $38.062 \pm 11.706$ & - & - & - & - & - & - \\
\hline \multicolumn{10}{|l|}{ A. reticulatus } \\
\hline$\# 1$ & 155.361 & 0,005 & $54.133 \pm 8.707$ & 114.190 & 0,005 & $39.787 \pm 7568$ & 41.170 & 0,01 & $14.345 \pm 2.589$ \\
\hline \#2 & - & - & - & - & - & - & 51.288 & 0,01 & $16.983 \pm 2.199$ \\
\hline Média \pm dp & & & & & & & $46.229 \pm 7.155$ & & $15.664 \pm 1.865$ \\
\hline \multicolumn{10}{|l|}{ D. bucephala } \\
\hline$\# 1$ & - & - & - & 3.828 .238 & 0,004 & $108.726 \pm 16567$ & - & - & - \\
\hline$\# 2$ & 4.493 .220 & 0,006 & $136.282 \pm 21.448$ & 4.250 .370 & 0,01 & $128.916 \pm 20.753$ & 254.536 & 0,02 & $7.720 \pm 2.643$ \\
\hline$\# 3$ & 4.360 .658 & 0,005 & $114.845 \pm 17.730$ & 4.119 .177 & 0,01 & $108.485 \pm 17.798$ & 194.090 & 0,02 & $5.112 \pm 2.196$ \\
\hline \#4 & 4.619 .693 & 0,009 & $164.812 \pm 25.652$ & 4.313 .672 & 0,01 & $153.895 \pm 25.324$ & 259.749 & 0,01 & $9.267 \pm 2.960$ \\
\hline Média \pm dp & $4.491 .190 \pm 129.529$ & & $138.646 \pm 25.467$ & $4.127 .864 \pm 215.549$ & & $125.006 \pm 21.508$ & $236125 \pm 36497$ & & $7.366 \pm 2.100$ \\
\hline \multicolumn{10}{|l|}{ O. guibei } \\
\hline$\# 1$ & - & - & - & 1.026 .950 & 0,003 & $60.516 \pm 11.983$ & - & - & - \\
\hline \#2 & - & - & - & 686.893 & 0,01 & $59.574 \pm 15.253$ & - & - & - \\
\hline Média $\pm \mathrm{dp}$ & & & & $855.173 \pm 314.422$ & & $59.825 \pm 23.583$ & & & \\
\hline \multicolumn{10}{|l|}{ S. mikanii } \\
\hline$\# 1$ & 925.604 & 0,009 & $93.119 \pm 19.484$ & 817.467 & 0,01 & $82.240 \pm 17.009$ & 112.714 & 0,01 & $11.339 \pm 2.608$ \\
\hline \#2 & 938.959 & 0,009 & $76.587 \pm 13.431$ & 827.766 & 0,01 & $67.518 \pm 12.711$ & 119.143 & 0,01 & $9.718 \pm 1.613$ \\
\hline Média \pm dp & $932.289 \pm 9.443$ & & $84.853 \pm 11690$ & $822.617 \pm 7.283$ & & $74.879 \pm 10.410$ & $115.929 \pm 4546$ & & $10.529 \pm 1.147$ \\
\hline S. neuwiedi & & & & & & & & & \\
\hline$\# 1$ & - & - & - & 805.136 & 0,003 & $40.398 \pm 7.590$ & - & - & - \\
\hline
\end{tabular}

CE, Coeficiente de erro de Schaeffer; dp, desvio padrão. 
Com o uso da técnica de imunohistoquímica foi possível distinguir e quantificar dois grupos de cones nas retinas aplanadas, os cones simples pequenos, marcados pelo anticorpo contra opsinas S de humanos (Figura 40), prováveis cones UV de serpentes; e os cones simples grandes juntamente com cones duplos (em espécies diurnas), marcados pelo anticorpo contra opsinas de cones L/M de humanos (Figura 41), que nas retinas de serpentes devem conter opsinas sensíveis ao comprimento de onda longo ou médio (cones $\mathrm{L} / \mathrm{M})$.

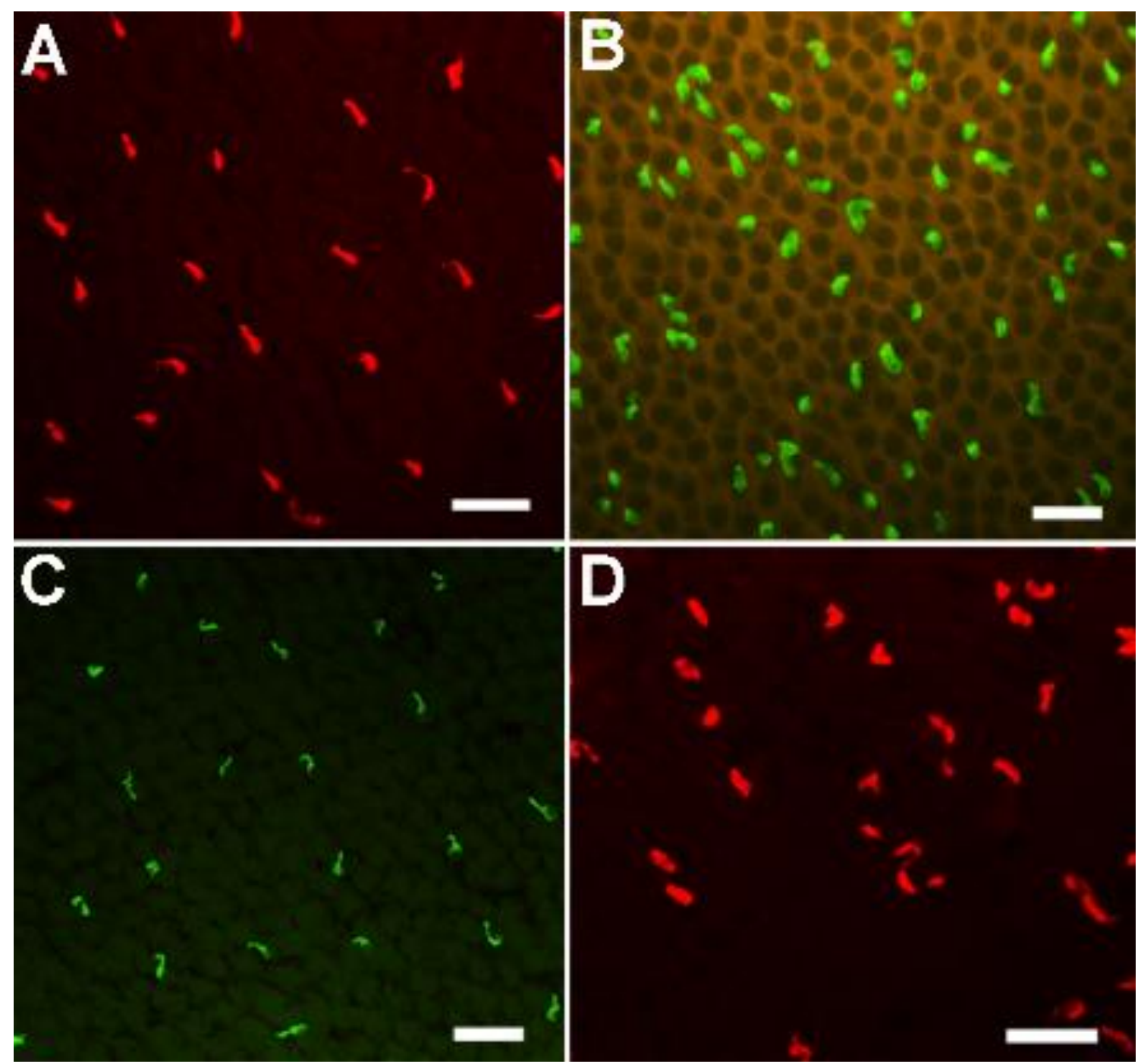

Figura 40. Imagens de retinas marcadas com o anticorpo JH455, anti opsinas-S de humanos. Nas retinas de serpentes diurnas $(A, C)$ e noturnas $(B, D)$ são evidenciados os segmentos externos de cones UV. A, E. aesculapii; B. D. bucepahala; C, S. pullatus; D, S. mikanii. Barras de escala $20 \mu \mathrm{m}$. 


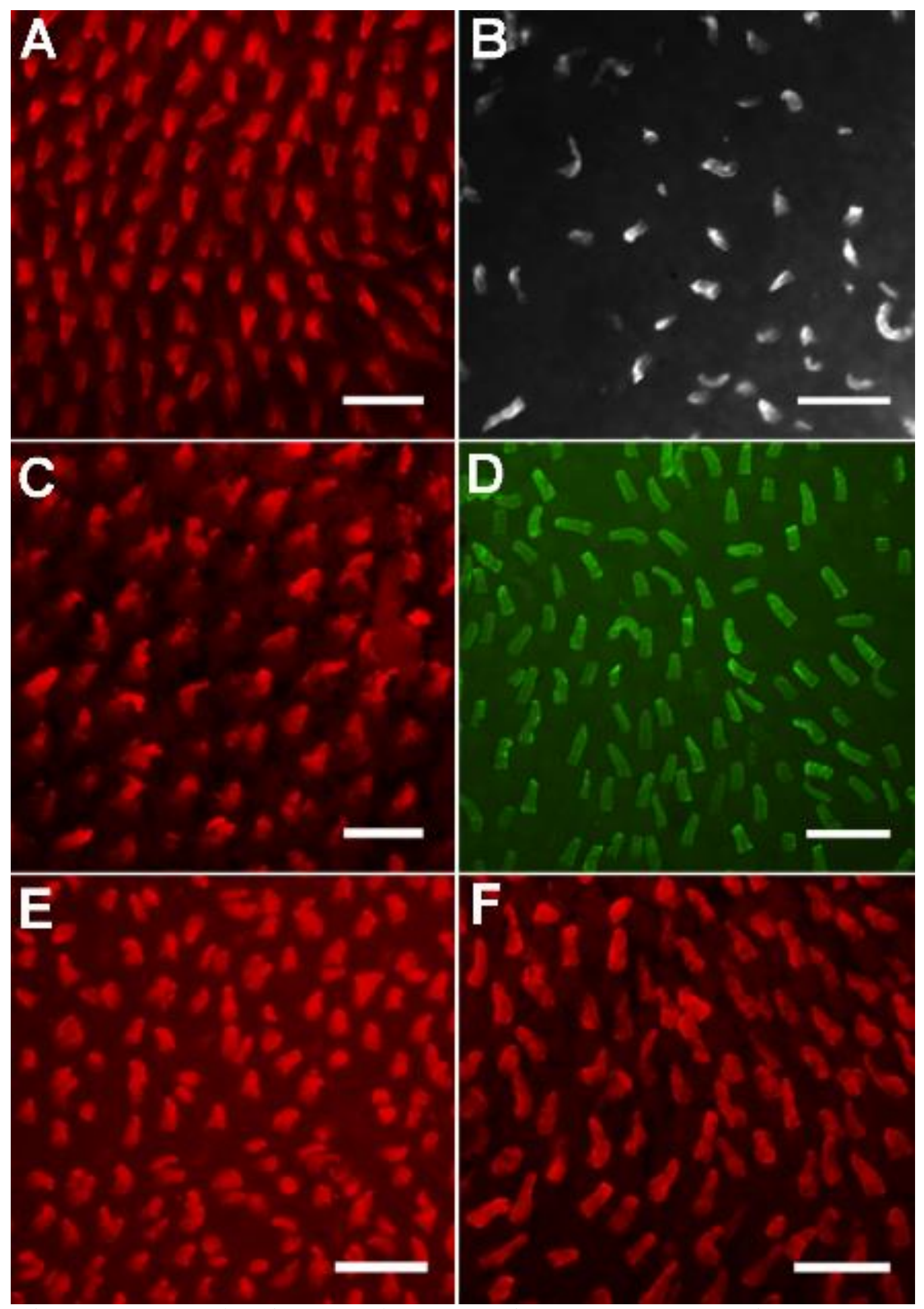

Figura 41. Imagens de retinas marcadas com o anticorpo JH492, contra opsinas-L/M. Nas retinas de serpentes diurnas (A, C, E) são observados os segmentos externos de cones simples e de cones duplos. Nas retinas de serpentes noturnas (B, D, F) são evidenciados os segmentos externos de cones simples. A, C. bicarinatus; B. O. guibei; C, H. modestus; D, D. bucepahala; E, T. dorsatus; F, S. mikanii. Barras de escala $20 \mu \mathrm{m}$. 
Os cones $\mathrm{L} / \mathrm{M}$ de serpentes apresentaram uma alta densidade com relação ao número total de fotorreceptores de serpentes diurnas (em torno de $80 \%$ ), com exceção da serpente aquática $H$. modestus que apresentou uma menor densidade em duas retinas (65\% da população de fotorreceptores) (Tabela 8). Nas espécies noturnas a população de cones L/M pode ser relacionada com a população total de cones apenas em S. mikanii $(78 \pm 12 \%)$ e em $D$. bucepahala $(96 \pm 27 \%)$. As análises estatísticas para verificar a similaridade entre os valores de densidade de cones $\mathrm{L} / \mathrm{M}$ foram feitas a partir das médias de densidade de 8 retinas de serpentes noturnas e 12 retinas de diurnas. Os valores de população total apresentaram diferença significativa entre os dois grupos, com $88.408 \pm 78.614$ células nas retinas de serpentes noturnas e $293.180 \pm 213.564$ nas retinas de diurnas $\left(\mathrm{t}_{(14,96)}=-3,028, p=0,008\right)$. Entretanto, a densidade média deste tipo celular não apresentou diferença significativa entre os dois grupos, com $6.377 \pm 3.182$ células $/ \mathrm{mm}^{2}$ em serpentes noturnas e $8.232 \pm 2.056$ células $/ \mathrm{mm}^{2}$ em retinas de diurnas $\left(\mathrm{t}_{(10,90)}=-1,458, p=0,173\right)$. A diferença observada para a população total de células está relacionada, portanto, à área das retinas, significativamente maior em serpentes de hábitos diurnos.

A população de cones UV teve uma menor densidade e os valores relativos foram mais baixos em serpentes diurnas (com variação de $1,3 \%$ da população de fotorreceptores em C. bicarinatus até $9 \%$ em E. poecilogyrus), do que nas noturnas (com variação de $9 \%$ da população de cones em A. reticulatus, até $27 \%$ em D. bucephala) (Tabela 9). A densidade média de cones UV foi significativamente maior em retinas de serpentes noturnas, com $1.251 \pm 635$ células $/ \mathrm{mm}^{2}$, estimada a partir da amostragem de 8 retinas, do que em serpentes diurnas, com $580 \pm 256$ células $/ \mathrm{mm}^{2}$, estimado a partir da contagem de células de 18 retinas $\left(\mathrm{t}_{(8,03)}=2,887, p=0,020\right)$. A população de cones UV, entretanto, não apresentou diferença entre os dois grupos de 
serpentes, com $18.717 \pm 17.284$ células nas retinas de serpentes noturnas e $16.860 \pm$ 12.222 células nas retinas das espécies diurnas $\left(\mathrm{t}_{(10,25)}=0,275, p=0,789\right)$.

Os valores de densidade e população total de cones L/M e de cones UV de cada retina analisada estão descritos nas Tabelas 8 e 9. Os gráficos da Figura 42 mostram as variações dos valores de densidade média e de população total de fotorreceptores, de cones, de cones L/M e de cones UV, nas retinas das serpentes diurnas e noturnas. Afim de possibilitar uma melhor visualização da distribuição dos fotorreceptores em retinas de serpentes diurnas, com valores mais baixos de densidade do que as noturnas, os valores de densidade média apenas deste grupo de serpentes foram inseridos no gráfico apresentado na Figura 43. Na Figura 44, a densidade de cones UV é relacionada ao sexo de cada indivíduo, afim de avaliar a possibilidade de dimorfismo sexual. 
Tabela 8. Análises estereológicas da população cones L/M de serpentes.

\begin{tabular}{|c|c|c|c|c|c|c|}
\hline Espécies & Retina & $\begin{array}{l}\text { Número total de } \\
\text { cones } L / M\end{array}$ & $\mathbf{C E}$ & $\begin{array}{c}\text { Dens Média de } \\
\text { cones } \mathbf{L} / \mathbf{M} \\
\text { (células/mm²) }\end{array}$ & $\begin{array}{c}\% \text { cones L/M } \\
\text { com relação ao } \\
\text { total de cones }\end{array}$ & $\begin{array}{l}\% \text { cones } \mathrm{L} / \mathrm{M} \text { com } \\
\text { relação ao total de } \\
\text { fotorreceptores }\end{array}$ \\
\hline \multicolumn{7}{|l|}{ Noturnas } \\
\hline A. pantostictus & $\# 1$ & 17.501 & 0,02 & $10.870 \pm 3.209$ & - & - \\
\hline A. reticulatus & $\# 1$ & 26.528 & 0,01 & $8.726 \pm 2.800$ & - & - \\
\hline \multirow{2}{*}{ O. guibei } & $\# 1$ & 95.389 & 0,01 & $5.621 \pm 768$ & - & $9,7 \pm 2,3$ \\
\hline & \#2 & 53.456 & 0,02 & $3.945 \pm 1.279$ & - & $4,9 \pm 1,7$ \\
\hline Média \pm dp & & $74.422 \pm 29.651$ & & $4.783 \pm 1.185$ & - & $7,3 \pm 3,4$ \\
\hline S. mikanii & $\# 1$ & 88.669 & 0,01 & $8.920 \pm 2.391$ & $78 \pm 12$ & $9,7 \pm 1,9$ \\
\hline \multirow{2}{*}{ D. bucephala } & $\# 1$ & 175.619 & 0,01 & $4.988 \pm 2.296$ & - & $5,4 \pm 2$ \\
\hline & $\# 2$ & 231.923 & 0,009 & $7.034 \pm 2.278$ & $96 \pm 27$ & $4,9 \pm 1,3$ \\
\hline \multirow{2}{*}{$\begin{array}{c}\text { Média } \pm \mathrm{dp} \\
\text { Diurnas }\end{array}$} & & $203.771 \pm 39.814$ & & $6.011 \pm 1.447$ & 96 & $5,2 \pm 0,4$ \\
\hline & & & & & & \\
\hline \multirow{3}{*}{$\begin{array}{l}\text { C. bicarinatus } \\
\text { Média } \pm \mathbf{d p}\end{array}$} & \#1 & 621.637 & 0,006 & $7.744 \pm 2.225$ & $87 \pm 6$ & - \\
\hline & \#2 & 536.514 & 0,01 & $9.690 \pm 2.312$ & $83 \pm 12$ & - \\
\hline & & $579.075 \pm 60.191$ & & $8.717 \pm 1.376$ & $85 \pm 3$ & \\
\hline \multirow{2}{*}{ E. aesculapii } & $\# 1$ & 390.412 & 0,01 & $10.976 \pm 2.815$ & $83 \pm 6$ & - \\
\hline & \#2 & 196.772 & 0,01 & $5.774 \pm 1.553$ & $83 \pm 10$ & - \\
\hline Média $\pm d p$ & & $293.592 \pm 136.924$ & & $8.375 \pm 3.678$ & 83 & \\
\hline E miliaris & $\# 1$ & 183.990 & 0,01 & $7.210 \pm 2.133$ & $76 \pm 10$ & - \\
\hline \multirow[t]{2}{*}{ E. poecilogyrus } & $\# 1$ & 178.347 & 0,01 & $7.203 \pm 2.036$ & $80 \pm 11$ & - \\
\hline & $\# 1$ & 101.876 & 0,01 & $10.167 \pm 3.054$ & $85 \pm 13$ & - \\
\hline \multirow[t]{2}{*}{ H. modestus } & \#2 & 60.027 & 0,02 & $5.345 \pm 1.575$ & $66 \pm 21$ & - \\
\hline & \#3 & 59.355 & 0,01 & $6.501 \pm 1.542$ & $64 \pm 15$ & - \\
\hline Média \pm dp & & $73.753 \pm 24.358$ & & $7.334 \pm 2.518$ & $72 \pm 12$ & - \\
\hline S. pullatus & $\# 1$ & 665.115 & 0,01 & $7.735 \pm 1.435$ & $80 \pm 10$ & - \\
\hline T. hypoconia & $\# 1$ & 212.811 & 0,01 & $8.602 \pm 2.014$ & $84 \pm 10$ & - \\
\hline T. dorsatus & $\# 1$ & 311.309 & 0,01 & $11.837 \pm 3.659$ & $89 \pm 6$ & - \\
\hline
\end{tabular}

$\overline{\mathrm{CE}}$, Coeficiente de erro de Schaeffer; dp, desvio padrão.

Tabela 9. Análises estereológicas da população cones UV de serpentes.

\begin{tabular}{|c|c|c|c|c|c|c|}
\hline Espécies & Retina & $\begin{array}{l}\text { Número total } \\
\text { de cones UV }\end{array}$ & $\mathbf{C E}$ & $\begin{array}{c}\text { Dens Média } \\
\text { de cones UV } \\
\left(\text { cels } / \mathbf{m m}^{2}\right) \\
\end{array}$ & $\begin{array}{l}\text { \% cones UV com } \\
\text { relação ao total de } \\
\text { cones }\end{array}$ & $\begin{array}{l}\% \text { cones UV com } \\
\text { relação ao total de } \\
\text { fotorreceptores }\end{array}$ \\
\hline \multicolumn{7}{|l|}{ Noturnas } \\
\hline A. pantostictus & $\# 1$ & 4.369 & 0,02 & $1.481 \pm 444$ & $9,7 \pm 2,8$ & - \\
\hline A. reticulatus & $\# 1$ & 4.553 & 0,01 & $1.508 \pm 562$ & $9 \pm 3,4$ & - \\
\hline \multirow{2}{*}{ D. bucephala } & $\# 1$ & 45.777 & 0,008 & $1.206 \pm 671$ & $27 \pm 17$ & $1,2 \pm 0,5$ \\
\hline & $\# 2$ & 41.178 & 0,009 & $1.469 \pm 678$ & $15 \pm 4$ & $0,9 \pm 0,4$ \\
\hline Média \pm dp & & $43.477 \pm 3.252$ & & $1.337 \pm 186$ & $21 \pm 8$ & $1 \pm 0,2$ \\
\hline \multirow{2}{*}{ O. guibei } & $\# 1$ & 10.224 & 0,04 & $619 \pm 309$ & - & $1,7 \pm 1$ \\
\hline & $\# 2$ & 24.335 & 0,02 & $2.111 \pm 1.011$ & - & $3,4 \pm 1,5$ \\
\hline Média \pm dp & & $17.280 \pm 9.978$ & & $1.365 \pm 1.055$ & - & $2,5 \pm 1,2$ \\
\hline S. mikanii & $\# 1$ & 19.129 & 0,01 & $1560 \pm 462$ & $16,5 \pm 5$ & $2,1 \pm 0,8$ \\
\hline \multicolumn{7}{|l|}{ Diurnas } \\
\hline C. bicarinatus & $\# 1$ & 6.859 & 0,06 & $123 \pm 132$ & $1,3 \pm 1,4$ & - \\
\hline \multirow{3}{*}{ E. aesculapii } & $\# 1$ & 12.105 & 0,03 & $631 \pm 347$ & $4,8 \pm 2,7$ & - \\
\hline & \#2 & 19.585 & 0,03 & $713 \pm 267$ & $6,4 \pm 2,6$ & - \\
\hline & \#3 & 30.952 & 0,01 & $957 \pm 272$ & $7,4 \pm 1,3$ & - \\
\hline Média \pm dp & & $20.881 \pm 9.490$ & & $767 \pm 170$ & $6,2 \pm 1,3$ & \\
\hline E miliaris & $\# 1$ & 29.568 & 0,01 & $850 \pm 297$ & $8,5 \pm 2,6$ & - \\
\hline \multirow{2}{*}{ E. poecilogyrus } & $\# 1$ & 19.541 & 0,03 & $730 \pm 341$ & $8,9 \pm 4,3$ & - \\
\hline & $\# 2$ & 23.245 & 0,01 & $876 \pm 319$ & $9,1 \pm 2,9$ & - \\
\hline Média \pm dp & & $21.393 \pm 2.620$ & & $803 \pm 103$ & $9 \pm 0,2$ & \\
\hline \multirow{2}{*}{ H. modestus } & $\# 1$ & 7.366 & 0,03 & $735 \pm 399$ & $6,6 \pm 2,9$ & - \\
\hline & $\# 2$ & 6.626 & 0,02 & $589 \pm 219$ & $5,4 \pm 1,7$ & - \\
\hline Média \pm dp & & $6.996 \pm 523$ & & $662 \pm 104$ & $6 \pm 0,8$ & \\
\hline S. pullatus & $\# 1$ & 53.381 & 0,02 & $569 \pm 195$ & $5,7 \pm 1,5$ & - \\
\hline T. natererii & $\# 1$ & 10.244 & 0,03 & $748 \pm 269$ & $5,5 \pm 1,4$ & - \\
\hline \multirow{2}{*}{ T. strigatus } & $\# 1$ & 3.330 & 0,06 & $195 \pm 141$ & $1,6 \pm 1$ & - \\
\hline & $\# 2$ & 14.861 & 0,02 & $451 \pm 167$ & $6 \pm 2,7$ & - \\
\hline Média \pm dp & & $9.095 \pm 8153$ & & $323 \pm 181$ & $3,7 \pm 3$ & \\
\hline \multirow{4}{*}{ T. dorsatus } & $\# 1$ & 8.228 & 0,05 & $336 \pm 166$ & $3,8 \pm 1,6$ & - \\
\hline & \#2 & 4.515 & 0,09 & $203 \pm 134$ & $2,9 \pm 1,8$ & - \\
\hline & \#3 & 15.756 & 0,03 & $678 \pm 185$ & $5,2 \pm 1,3$ & - \\
\hline & $\# 4$ & 20.552 & 0,02 & $778 \pm 256$ & $6,9 \pm 1,9$ & - \\
\hline Média \pm dp & & $12.263 \pm 7.239$ & & $185 \pm 52$ & $4,7 \pm 1,8$ & \\
\hline
\end{tabular}

CE, Coeficiente de erro de Schaeffer; dp, desvio padrão. 

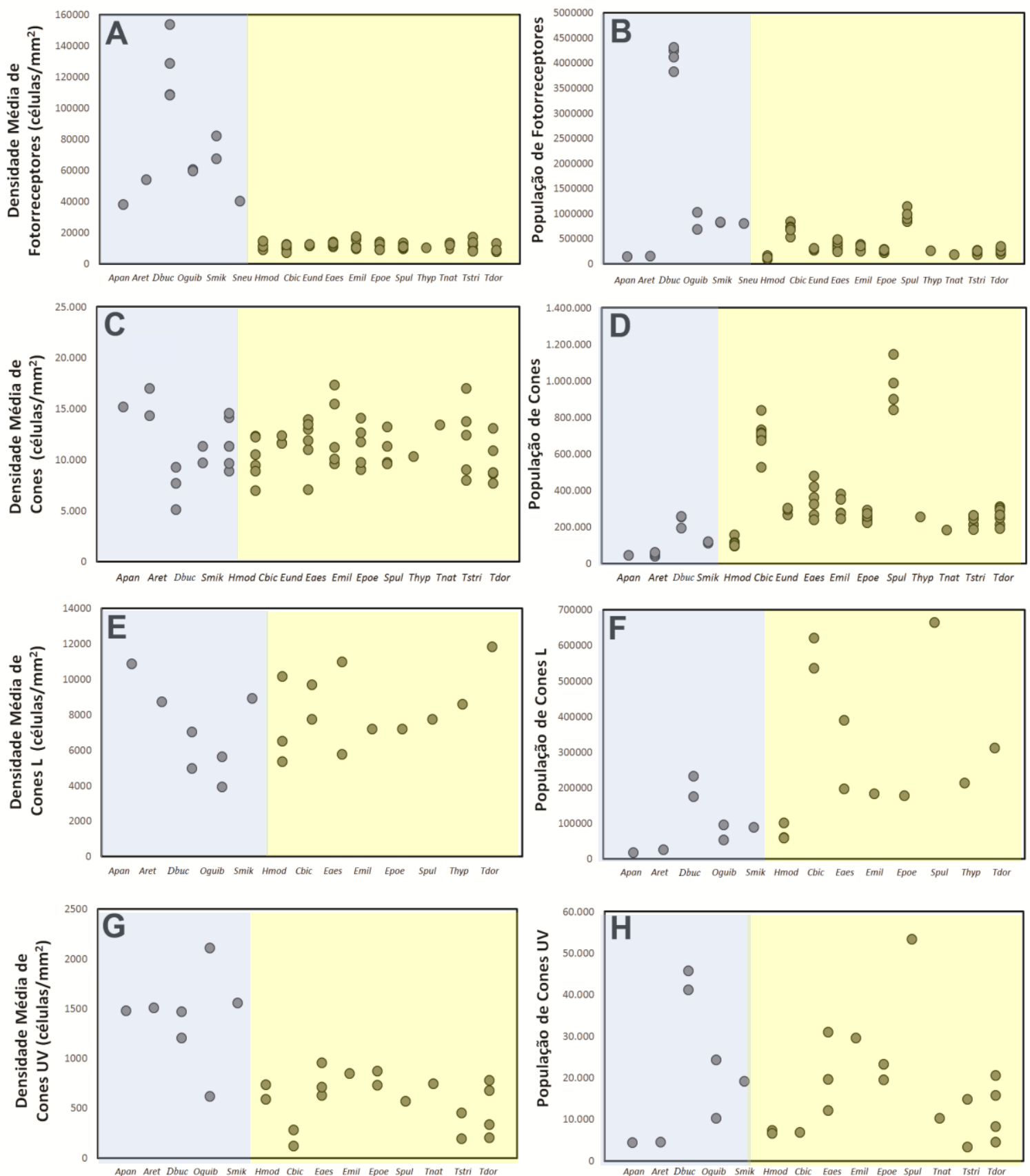

Figura 42. Variações da densidade média $\left(\right.$ células $/ \mathrm{mm}^{2}$ ) e do número total da população de fotorreceptores (A, B), da população total de cones $(C, D)$, da população de cones L/M (E, F) e da população de cones UV $(\mathrm{G}, \mathrm{H})$, de retinas de serpentes noturnas (em azul) e diurnas (em amarelo): Apan, Atractus pantostictus; Aret, A. reticulatus; Dbuc, Dipsas bucephala; Ogui, Oxyrhopus guibei; Smik, Sibynomorphus mikanii; Snew, S. neuwiedii; Hmo, Helicops modestus; Cbic, Chironius bicarinatus; Eund, Echinantera undulata; Eaes, Erythrolamprus aesculapii; Emil, E. miliaris; Epoe, E. poecilogyrus; Spul, Spilotes pullatus; Thyp, Thamnodynastes hypoconia; Tnat, T. natererii; Tstri, T. strigatus; Tdor, Tomodon dorsatus. 


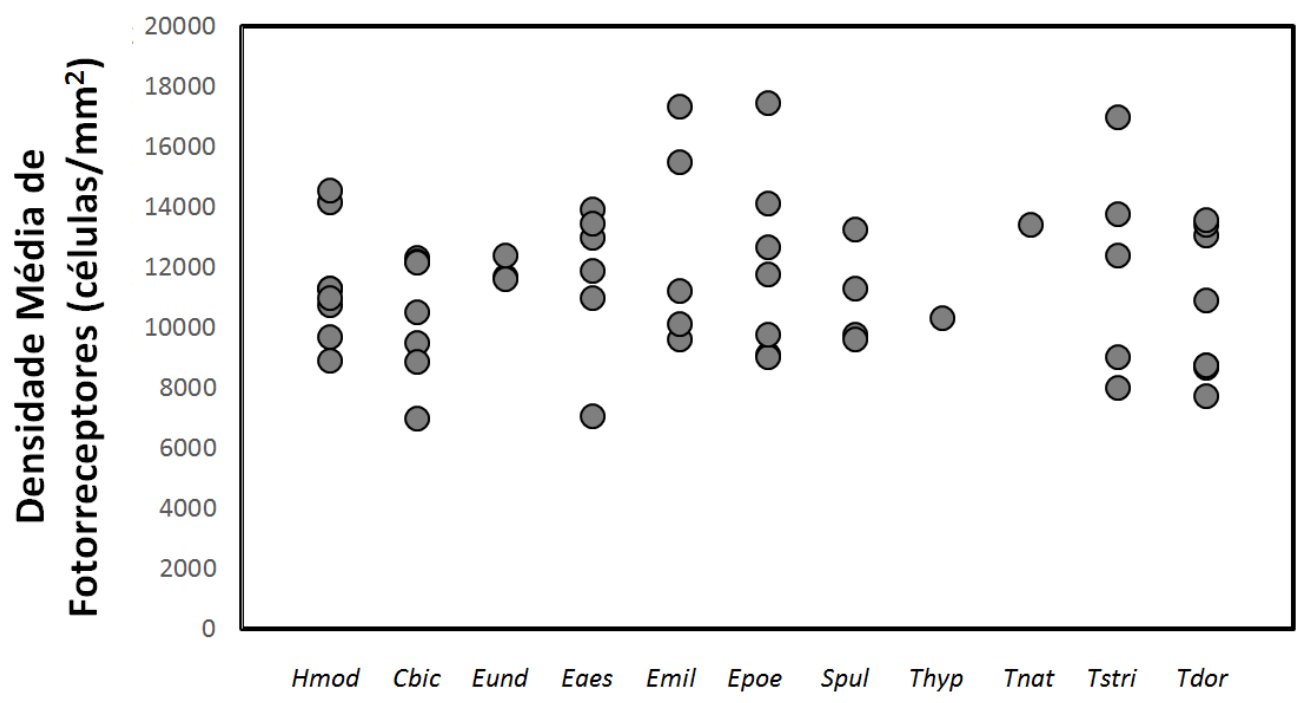

Figura 43. Densidade média (células $/ \mathrm{mm}^{2}$ ) de fotorreceptores de serpentes diurnas. Hmo, Helicops modestus; Cbic, Chironius bicarinatus; Eund, Echinantera undulata; Eaes, Erythrolamprus aesculapii; Emil, E. miliaris; Epoe, E. poecilogyrus; Spul, Spilotes pullatus; Thyp, Thamnodynastes hypoconia; Tstri, T. strigatus; Tdor, Tomodon dorsatus.

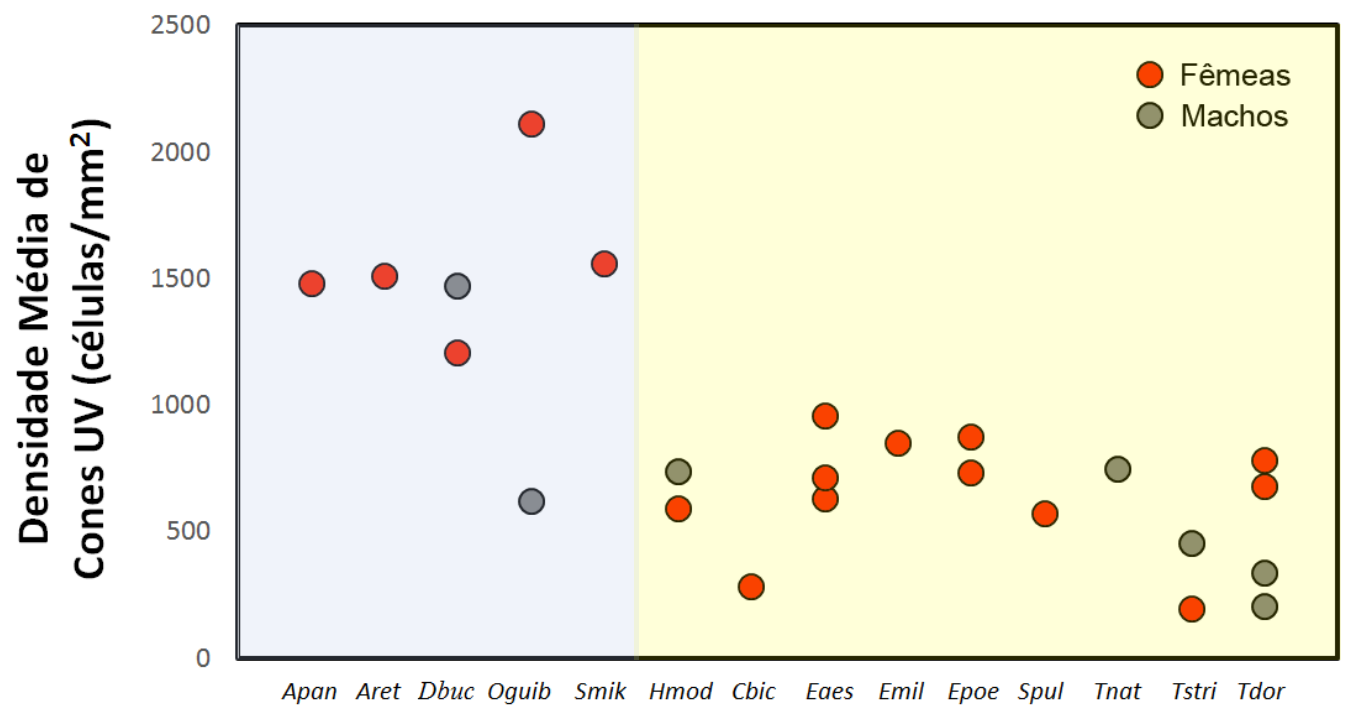

Figura 44. Densidade média de cones UV (células $/ \mathrm{mm}^{2}$ ) em retinas de serpentes noturnas (em azul) e diurnas (em amarelo), com distinção entre o sexo: fêmeas diferenciadas em vermelho e machos em cinza. Apan, Atractus pantostictus; Aret, A. reticulatus; Dbuc, Dipsas bucephala; Ogui, Oxyrhopus guibei; Smik, Sibynomorphus mikanii; Hmo, Helicops modestus; Cbic, Chironius bicarinatus; Eaes, Erythrolamprus aesculapii; Emil, E. miliaris; Epoe, E. poecilogyrus; Spul, Spilotes pullatus; Tstri, Thamnodynastes strigatus; Tdor, Tomodon dorsatus. 


\section{Relação entre a densidade de fotorreceptores e de células da CCG}

Serpentes de hábitos noturnos apresentaram alta densidade de fotorreceptores, com relação à de células da CCG, chegando à proporção de 9:1 na espécie $O$. guibei. Serpentes diurnas, por sua vez, apresentaram pequena variação entre a densidade de fotorreceptores e a de células da CCG, com proporção variando entre 0,9:1 em $T$. dorsatus e 1,5:1 em S. pullatus e E. poecilogyrus (Tabela 10). Esta proporção foi estimada a partir das médias dos valores de densidade média de fotorreceptores e de células da CCG de todas as retinas quantificadas por espécie. Os valores das médias das densidades e da proporção estimada entre fotorreceptores e células da CCG estão apresentados na Tabela 10. O gráfico da Figura 45 mostra a variação de densidade de fotoreceptores e células da CCG em cada retina quantificada de serpentes diurnas e noturnas.

Tabela 10. Média das densidades de fotorreceptores e de células da CCG de todas retinas quantificadas e proporção entre fotorreceptores e células da CCG estimada com base nas médias das densidades.

\begin{tabular}{|c|c|c|c|}
\hline Espécies & $\begin{array}{c}\text { Média da Densidade } \\
\text { de Fotorreceptores } \\
\text { (células/mm²) }\end{array}$ & $\begin{array}{c}\text { Média da Densidade } \\
\text { de Células da CCG } \\
\text { (células/mm²) }\end{array}$ & $\begin{array}{c}\text { Proporção } \\
\text { Fotorreceptores:CCG }\end{array}$ \\
\hline \multicolumn{4}{|l|}{ Noturnas } \\
\hline A. pantostictus & 38.062 & 5.532 & 6,9 \\
\hline A. reticulatus & 54.133 & 10.330 & 5,2 \\
\hline O. guibei & 60.045 & 7.525 & 8 \\
\hline S. mikanii & 74.879 & 8.250 & 9,1 \\
\hline S. neuwiedii & 40.398 & 6.570 & 6,1 \\
\hline \multicolumn{4}{|l|}{ Diurnas } \\
\hline C. bicarinatus & 10.364 & 7.833 & 1,2 \\
\hline E. undulata & 11.893 & 9.146 & 1,3 \\
\hline E. aesculapii & 11.717 & 9.637 & 1,3 \\
\hline E. miliaris & 12.749 & 9.061 & 1,2 \\
\hline E. poecilogyrus & 11.985 & 8.185 & 1,4 \\
\hline H. modestus & 11.455 & 9.603 & 1,5 \\
\hline S. pullatus & 10.988 & 7.142 & 1,5 \\
\hline T. strigatus & 12.036 & 10.881 & 1,1 \\
\hline T. dorsatus & 10.911 & 11.882 & 0,9 \\
\hline
\end{tabular}




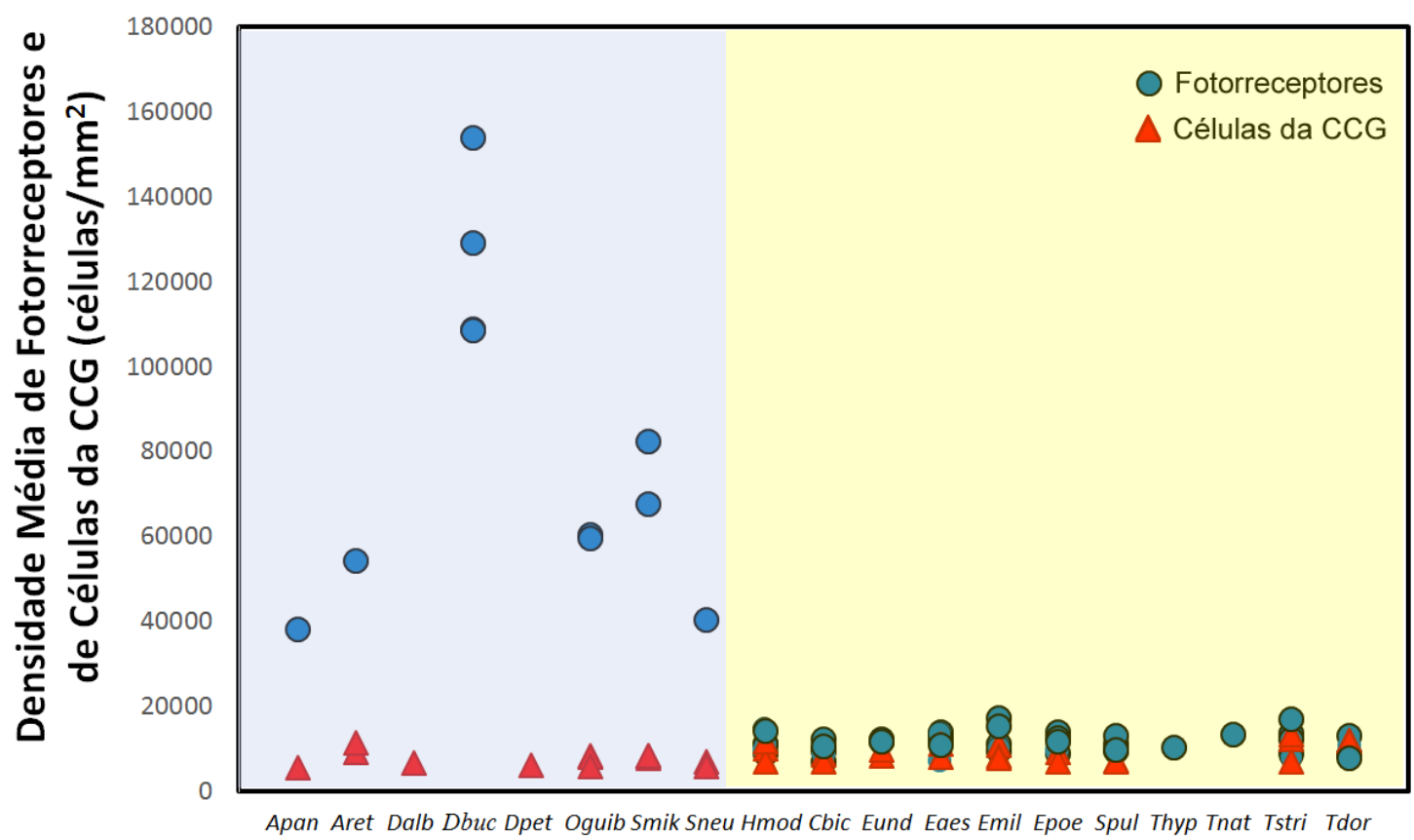

Figura 45. Gráfico da densidade média de fotorreceptores e de células da CCG, em retinas de serpentes noturnas (azul) e diurnas (amarelo): Apan, A. pantostictus; Aret, A. reticulatus; Dalb, D. albifrons; Dbuc, D. bucephala; Dpet, D. petersi; Oguib, O. guibei; Smik, S. mikanii; Sneu, S. neuwiedi; Hmod, H. modestus; Cbic, C. bicarinatus; Eund, E. undulata; Eaes, E. aesculapii; Emil, E. miliaris; E poe, E. poecilogyrus; Spul, S. pullatus; Thyp, T. hypoconia; Tnat, T. natererii; Tstri, T. strigatus; Tdor, T. dorsatus. 


\section{Topografia de células nas retinas}

Mapas de isodensidade foram gerados a partir dos valores de densidade de cada campo amostrado de cada retina, e mostraram variações quanto aos tipos de especialização (area centralis ou faixa visual), e as regiões de maior densidade celular, tanto para a população de fotorreceptores, quanto para a de células da CCG, nas diferentes espécies de serpentes. A Tabela 11 apresenta os tipos de distribuição e as regiões de maior densidade observados em cada espécie, para células da CCG, fotorreceptores, cones L/M e cones UV. Os mapas de isodensidade estão ilustrados nas Figuras 46 a 59.

Variações quanto aos tipos de especialização das retinas puderam ser traçadas ao comparar os grupos de serpentes diurnas e noturnas. De maneira geral, serpentes de hábitos noturnos apresentaram area centralis, enquanto a maioria das espécies diurnas apresentou faixa visual, com maior densidade de células na região central da retina, tanto para a distribuição de fotorreceptores quanto para a de células da CCG, com exceção apenas de $H$. modestus e $T$. strigatus. A espécie aquática $H$. modestus apresentou area centralis com maior concentração de células da CCG na região central, e maior densidade de fotorreceptores na região ventro-temporal. A espécie semiarborícola T. strigatus apresentou area centralis com maior densidade de células da CCG na região nasal e a distribuição de fotorreceptores apresentou uma faixa horizontal pouco denfinida, com maior densidade de células na região central.

Nas serpentes noturnas, a região de maior densidade de células variou entre as espécies; a maioria apresentou area centralis na região central ou ventral da retina. A serpente fossorial Atractus apresentou maior densidade de células na região dorsal da retina. Uma distribuição difusa, sem a formação de área ou faixa definidas foi observada para as células da CCG de $O$. guibei e de $S$. neuwiedi. 
A distribuição de cones L/M acompanhou a distribuição de fotorreceptores em todas as espécies, exceto na serpente aquática $H$. modestus, que apresentou uma faixa vertical na região nasal da retina. A distribuição de cones L/M em $O$. guibei se mostrou difusa, sem definição de uma área ou faixa, bem como as células da CCG nesta espécie. Em T. strigatus, o mapa de distribuição de cones L/M também teve aspecto difuso.

Os mapas de isodensidade da população de cones UV se mostraram similares entre a maioria das espécies, tanto de hábitos diurnos quanto noturnos, todas apresentando distribuição do tipo area centralis. A localização destas áreas variou entre as espécies, e nenhum padrão de localização da região de maior densidade parece estar relacionado com o uso de ambiente: espécies terrícolas apresentaram area na região central, ventral ou nasal da retina, da mesma forma que espécies arborícolas. Esta regionalização pode, portanto, estar mais relacionada à filogenia das espécies. Serpentes do gênero Erythrolamprus, por exemplo, apresentaram area centralis de cones UV na região central da retina. Por outro lado, serpentes da tribo Tachymenini, T.dorsatus e $T$. strigatus não compartilharam esta característica, sendo que primeira apresentou area na região ventral e a segunda, na região central da retina. 
Tabela 11. Variações da topografia de células da Camada de Células Ganglionates (CCG), de fotorreceptores, de cones L/M e de cones UV nas retinas de serpentes diurnas e noturnas.

\begin{tabular}{|c|c|c|c|c|c|c|c|c|c|}
\hline Espécies & Hábitat & Células da CCG & Região & Fotorreceptores & Região & Cones L/M & Região & Cones UV & Região \\
\hline \multicolumn{10}{|l|}{ Noturnas } \\
\hline A. reticulatus & Fs & area centralis & dorso-temporal & area centralis & dorso-temporal & area centralis & dorso- temporal & area centralis & central \\
\hline D. bucephala & $\mathrm{Ar}$ & area centralis & ventral & area centralis & ventral & area centralis & ventral & area centralis & ventral \\
\hline O. guibei & $\mathrm{Te}$ & Difuso & temporal & area centralis & central & difuso & temporal & area centralis & nasal \\
\hline S. mikanii & $\mathrm{Te}$ & Difuso & ventral & area centralis & temporal & area centralis & temporal & area centralis & ventral \\
\hline S. neuwiedii & $\mathrm{Te}$ & Difuso & dorsal & area centralis & central & - & - & - & - \\
\hline \multicolumn{10}{|l|}{ Diurnas } \\
\hline C. bicarinatus & $\mathrm{Ar}$ & faixa horizontal & central & faixa horizontal & central & faixa horizontal & central & area centralis & nasal \\
\hline E. undulata & $\mathrm{Te}$ & faixa horizontal & central & faixa horizontal & central & - & - & - & - \\
\hline E. aesculapii & $\mathrm{Te}$ & faixa horizontal & central & faixa horizontal & central & faixa horizontal & nasal & area centralis & central \\
\hline E. miliaris & S-Aq & faixa horizontal & central & faixa horizontal & central & faixa horizontal & central & area centralis & central \\
\hline E. poecilogyrus & $\mathrm{Te}$ & faixa horizontal & central & faixa horizontal & central & - & - & area centralis & central \\
\hline H. modestus & $\mathrm{Aq}$ & area centralis & central & area centralis & ventro-temporal & faixa vertical & nasal & area centralis & ventral \\
\hline S. pullatus & $\mathrm{Ar}$ & faixa horizontal & central & faixa horizontal & central & - & - & area centralis & ventral \\
\hline T. strigatus & S-Ar & area centralis & nasal & faixa horizontal & central & difuso & central & area centralis & central \\
\hline T. dorsatus & $\mathrm{Te}$ & faixa horizontal & central & faixa horizontal & central & faixa horizontal & central & area centralis & ventral \\
\hline
\end{tabular}

Aq, aquática; Ar, arborícola; Fs, fossorial.; S-Aq, semi-aquática; S-Ar, semi-arborícola; Te, terrícola. 


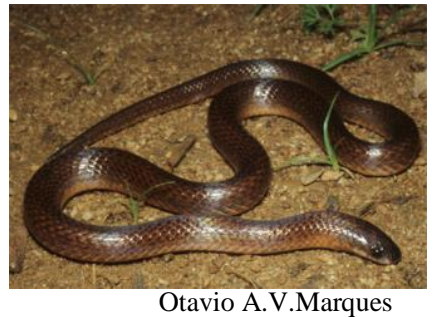

Otavio A.V.Marques

\section{Atractus reticulatus}

Espécie fossorial, de hábito noturno.

Alimentação: anelídeos.
Células da CCG

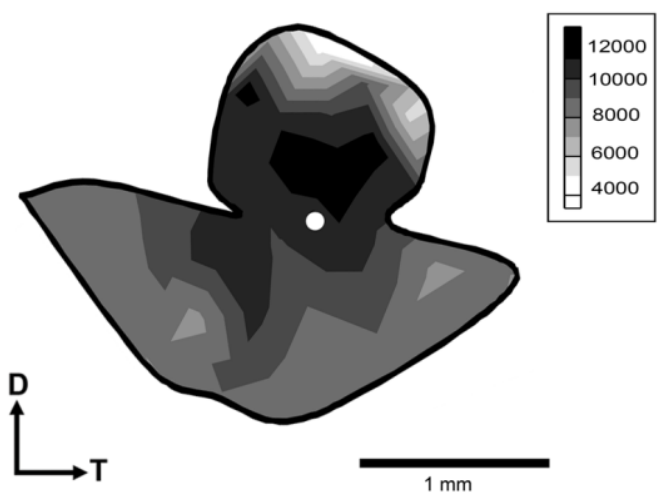

Bastonetes

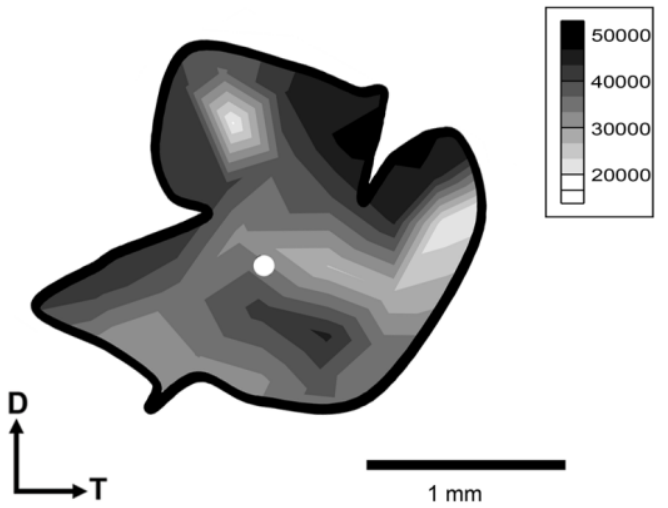

Cones L

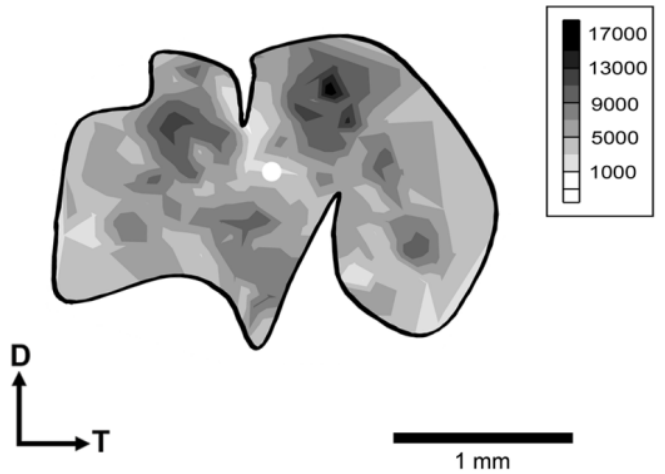

Fotorreceptores

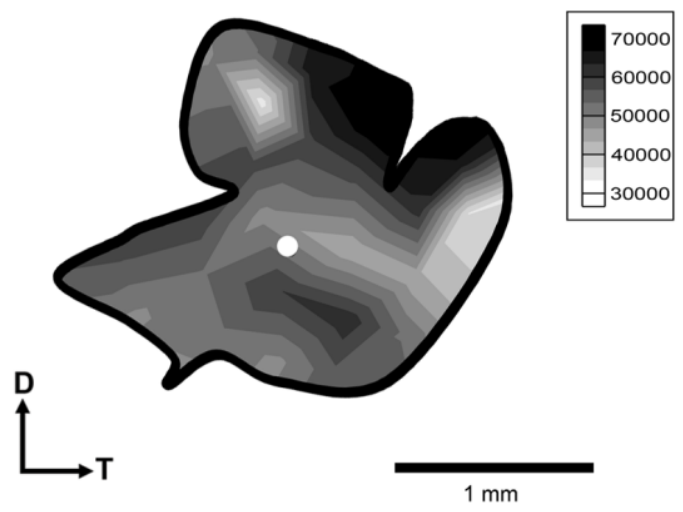

Cones

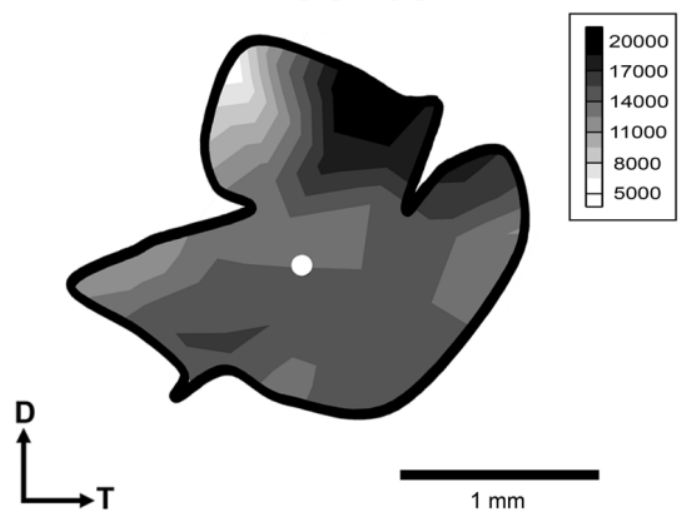

Cones UV

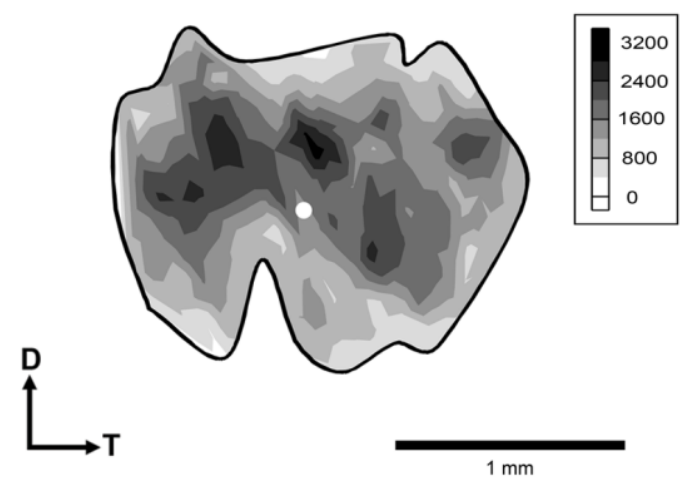

Figura 46. Mapas de isodensidade de neurônios de retinas de A. reticulatus. Os mapas apresentam distribuição do tipo area centralis anisotrópica, todas localizadas na região dorsal da retina. As barras de gradiente de cinza ao lado de cada mapa representam o número de células por $\mathrm{mm}^{2}$. A saída do nervo óptico está representada pelo ponto branco. $\mathrm{D}$, dorsal; $\mathrm{T}$, temporal. 


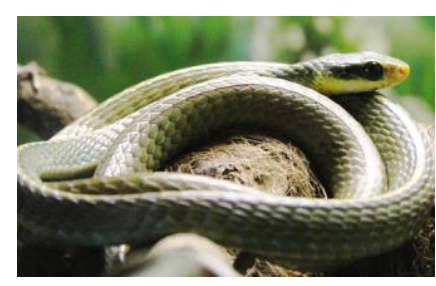

\section{Chironius bicarinatus}

Espécie semi-arborícola, de hábito diurno.

Alimentação: anfíbios anuros.
Células da CCG
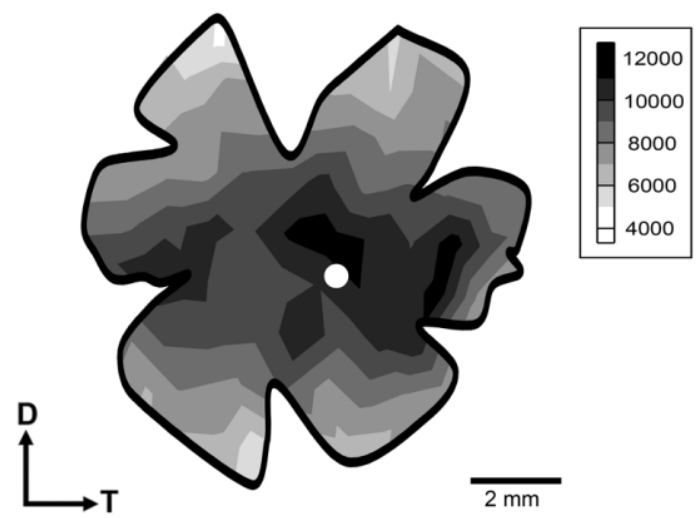

Cones L
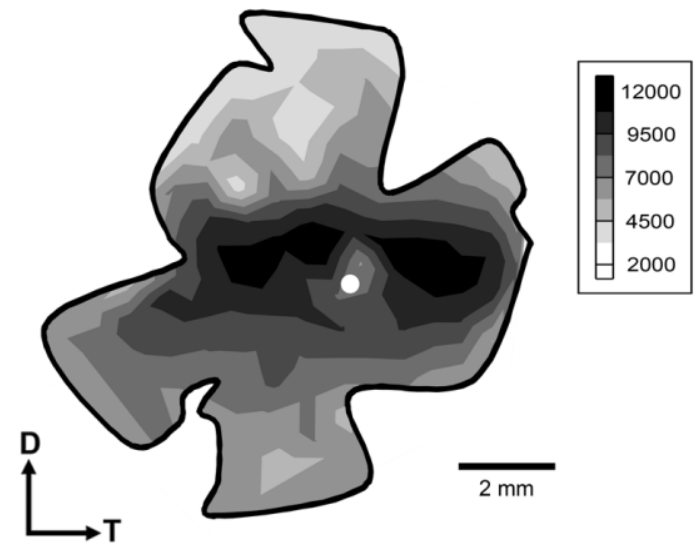

Fotorreceptores

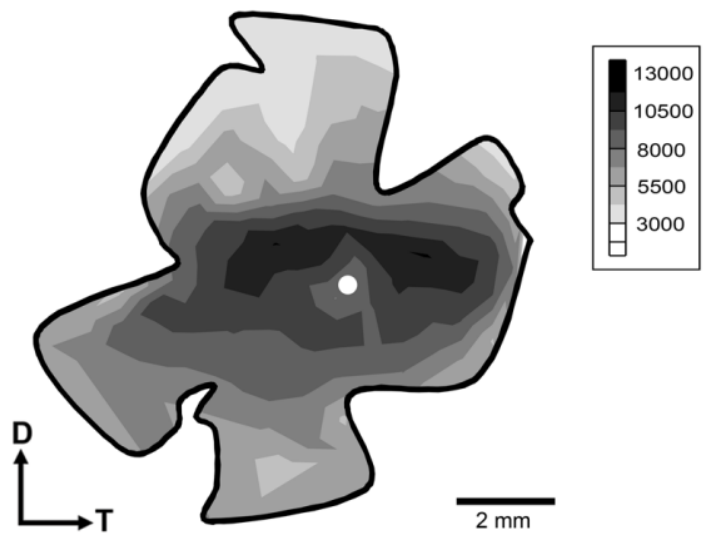

Cones UV
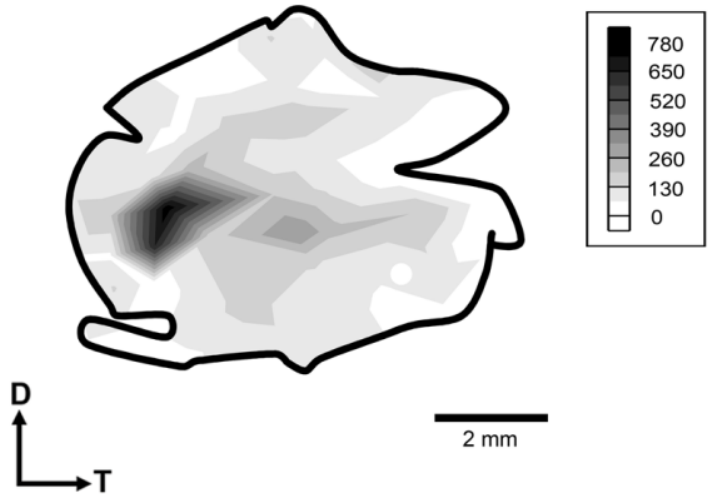

Figura 47. Mapas de isodensidade de neurônios de retinas de C. bicarinatus. Distribuição em faixa visual, com exceção da area centralis dos cones UV. As barras de gradiente de cinza ao lado de cada mapa representam o número de células por $\mathrm{mm}^{2}$. A saída do nervo óptico está representada pelo ponto branco. D, dorsal; T, temporal. 


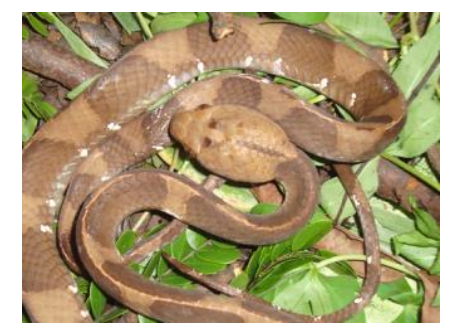

\section{Dipsas bucephala}

Espécie arborícola, de hábito noturno e crepuscular.

Alimentação: moluscos.

Células da CCG

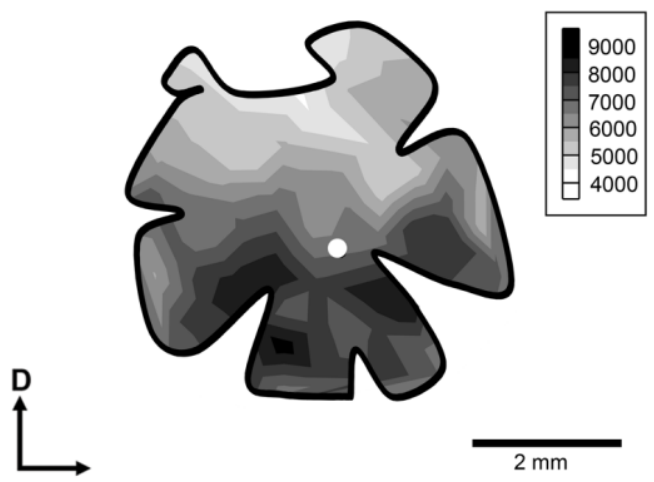

Bastonetes

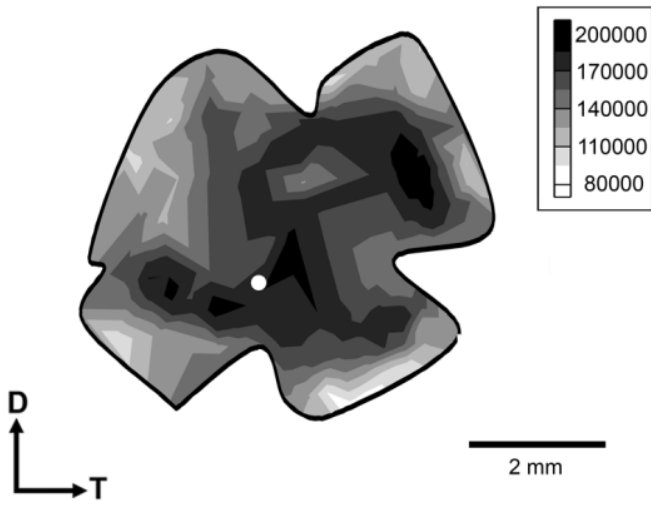

Cones L

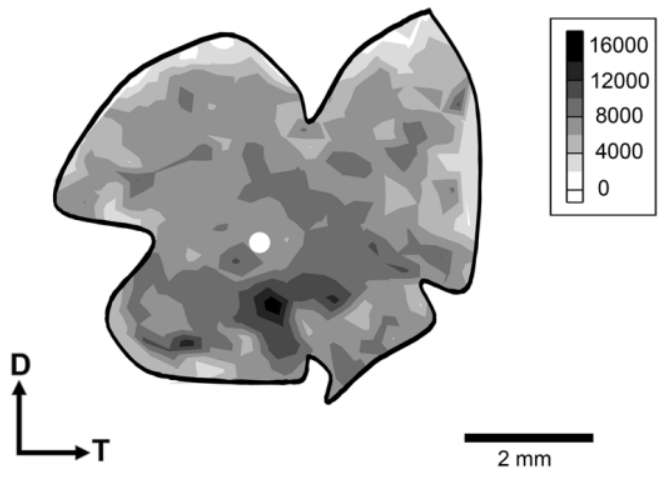

Fotorreceptores

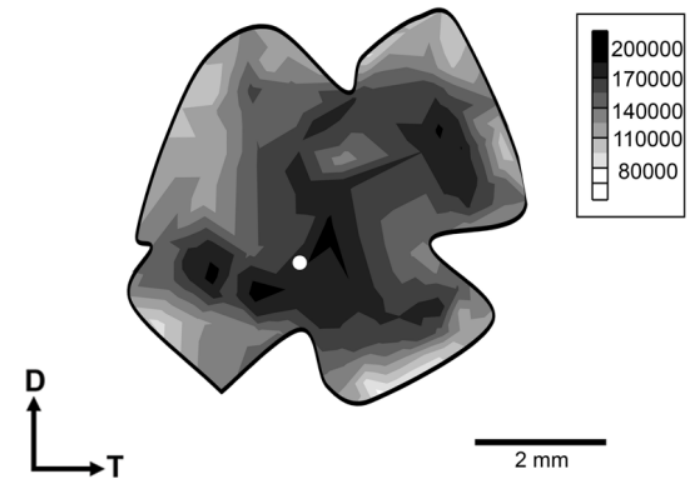

Cones

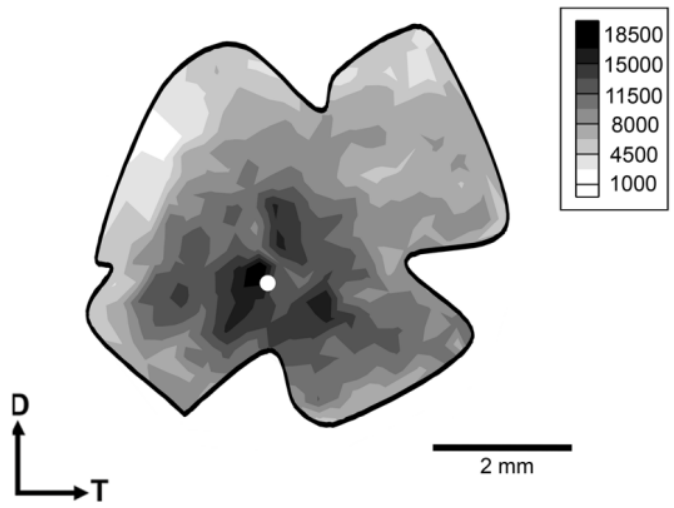

Cones UV

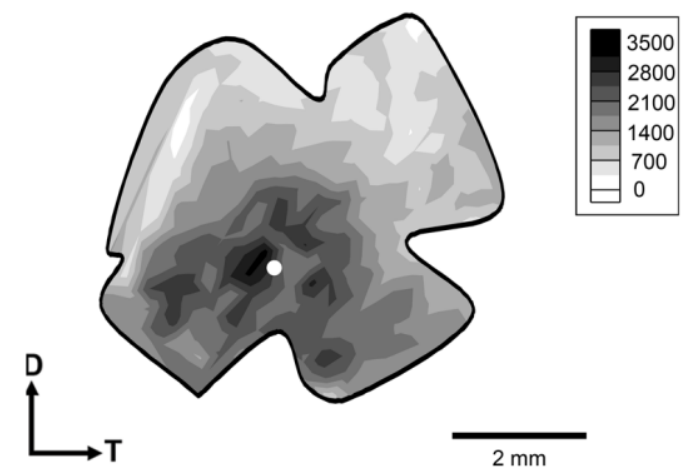

Figura 48. Mapas de isodensidade de neurônios de retinas de D. bucephala. Distribuição de células do tipo area centralis anisotrópica na região ventral ou central da retina. As barras de gradiente de cinza ao lado de cada mapa representam o número de células por $\mathrm{mm}^{2}$. A saída do nervo óptico está representada pelo ponto branco. D, dorsal; T, temporal. 


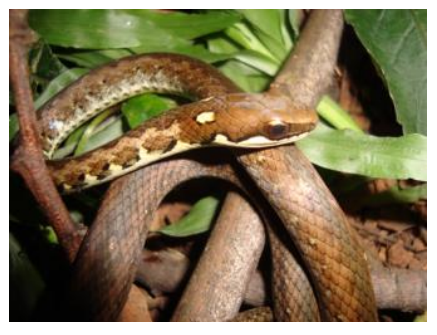

\section{Echinantera undulata}

Espécie terrícola, de hábito diurno.

Alimentação: anfíbios anuros

\section{Células da CCG}

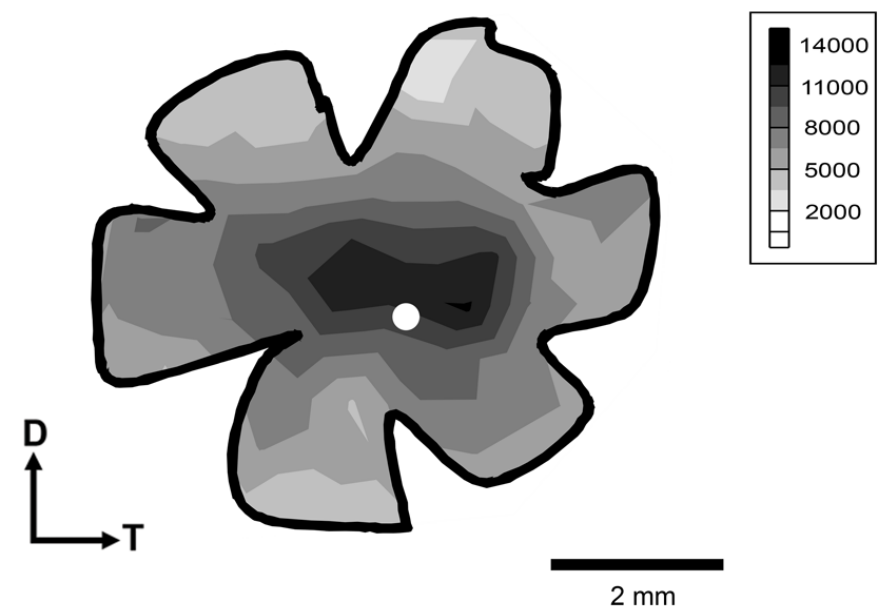

\section{Fotorreceptores}

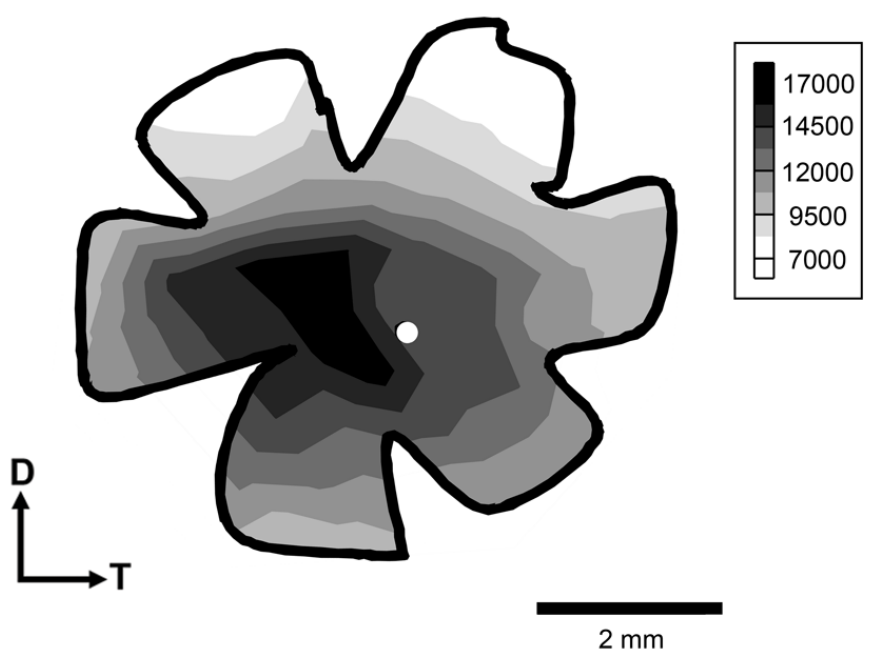

Figura 49. Mapas de isodensidade de neurônios células da CCG e fotorreceptores de retina de E. undulata, com distribuição em faixa visual. As barras de gradiente de cinza ao lado dos mapas representam o número de células por $\mathrm{mm}^{2}$. A saída do nervo óptico está representada pelo ponto branco. $\mathrm{D}$, dorsal; $\mathrm{T}$, temporal. 


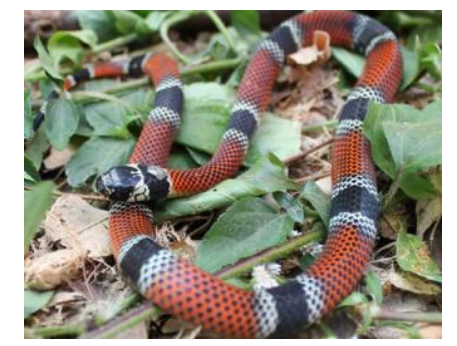

\section{Erythrolamprus aesculapii}

Espécie terrícola, de hábito crepuscular.

Alimentação: ofiófaga.

\section{Células da CCG}

Fotorreceptores
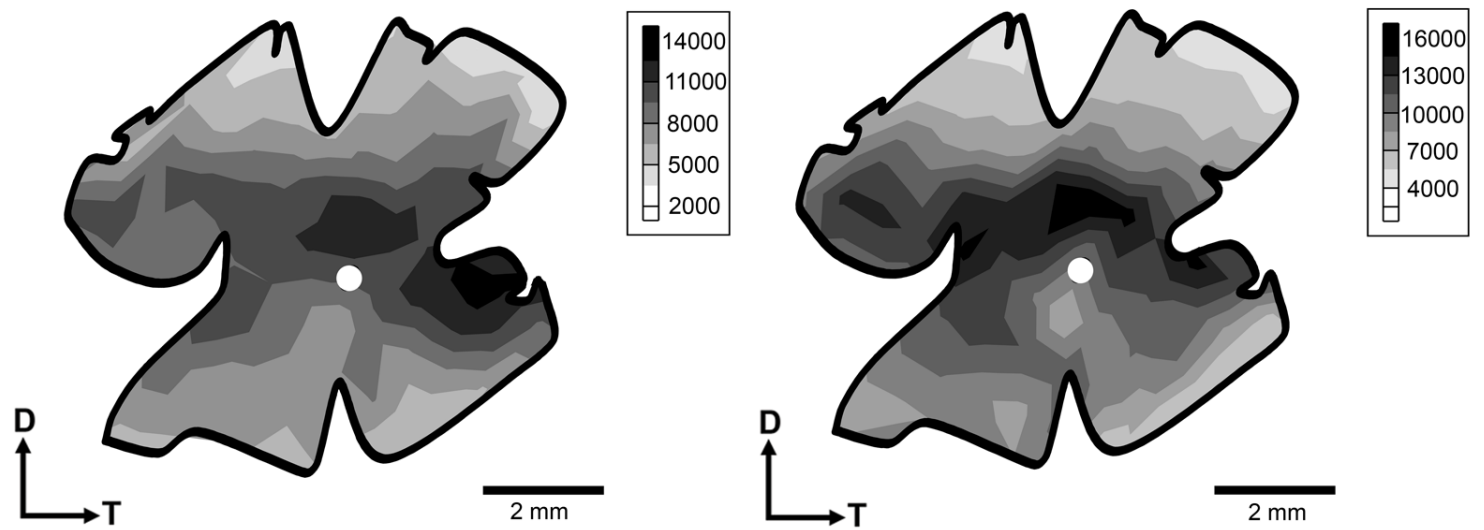

Cones L
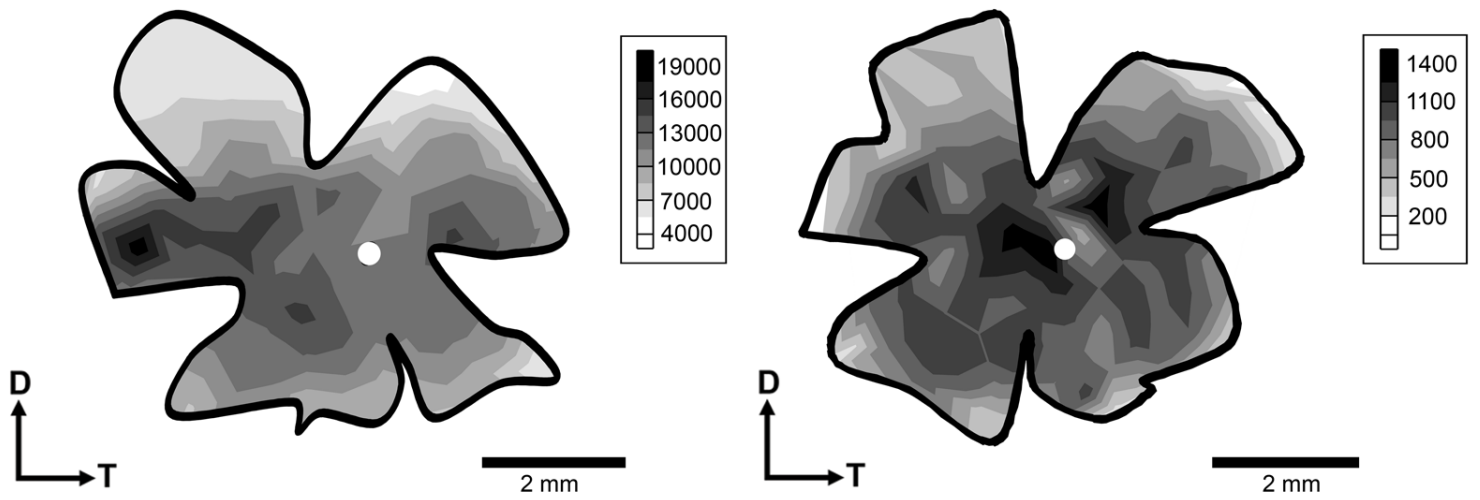

Figura 50. Mapas de isodensidade de neurônios de retinas de E.aesculapii, com faixa visual, para células da CCG, fotorreceptores e cones L/M. A população de cones UV apresentou distribuição do tipo area centralis na região central da retina. As barras de gradiente de cinza ao lado de cada mapa representam o número de células por $\mathrm{mm}^{2}$. A saída do nervo óptico está representada pelo ponto branco. $\mathrm{D}$, dorsal; $\mathrm{T}$, temporal. 


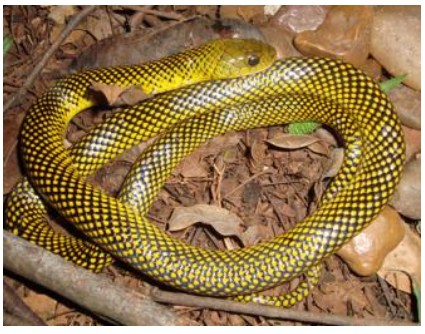

\section{Erythrolamprus miliaris}

Espécie semi-aquática, de hábito diurno e noturno.

Alimentação: generalista.

Células da CCG

Fotorreceptores
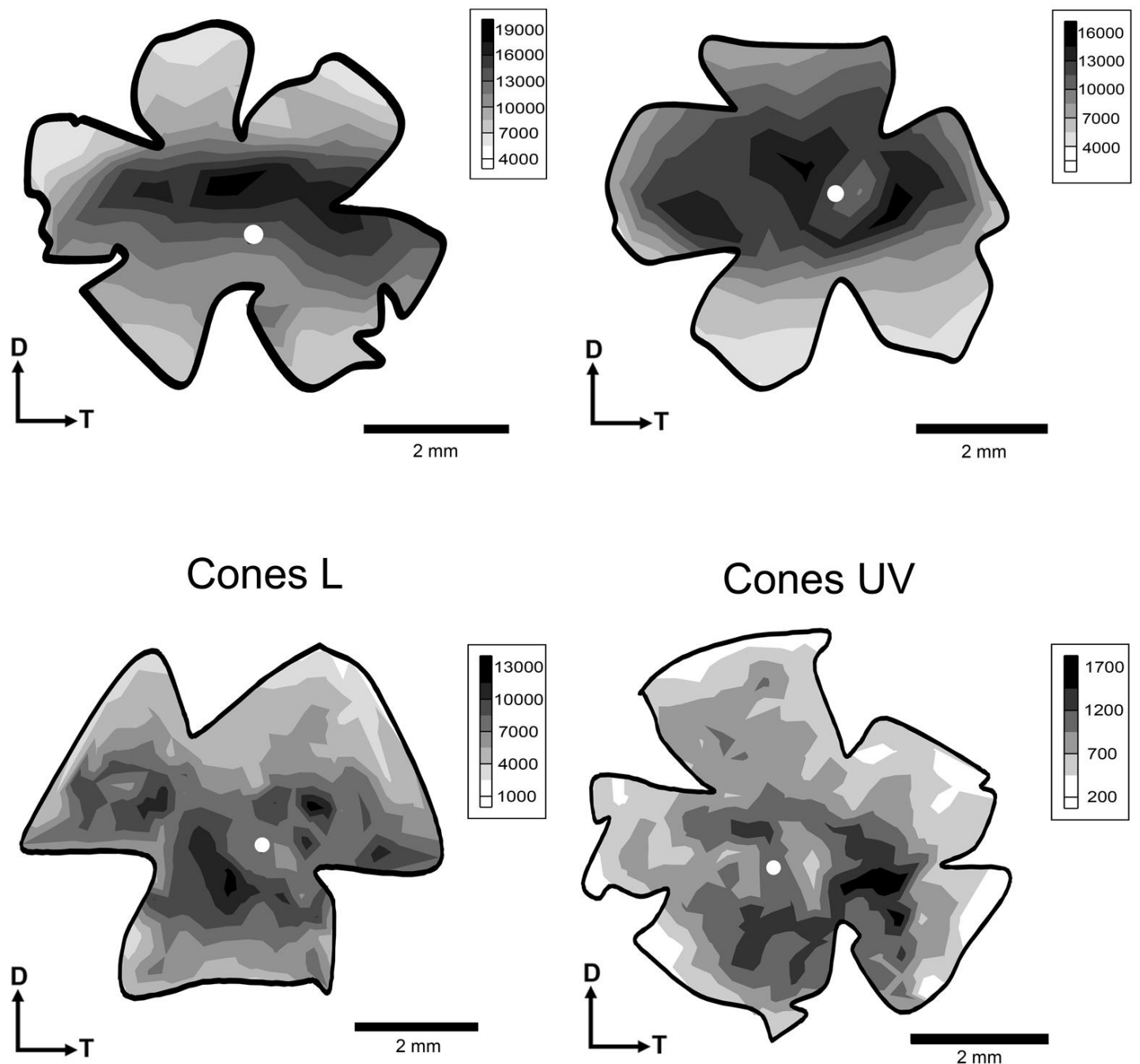

Figura 51. Mapas de isodensidade de neurônios de retinas de E. miliaris, com faixa visual, para células da CCG e fotorreceptores, e uma faixa pouco definida para cones L/M. A população de cones UV apresentou distribuição do tipo area centralis na região ventral da retina. As barras de gradiente de cinza ao lado de cada mapa representam o número de células por $\mathrm{mm}^{2}$. A saída do nervo óptico está representada pelo ponto branco. $\mathrm{D}$, dorsal; T, temporal. 


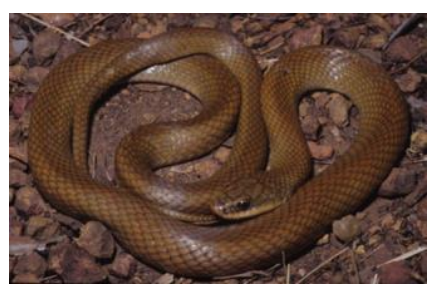

Otavio A.V. Marques

\section{Erythrolamprus poecilogyrus}

Espécie terrícola, de hábito diurno e noturno.

Alimentação: lagartos e anfíbios anuros.

Células da CCG

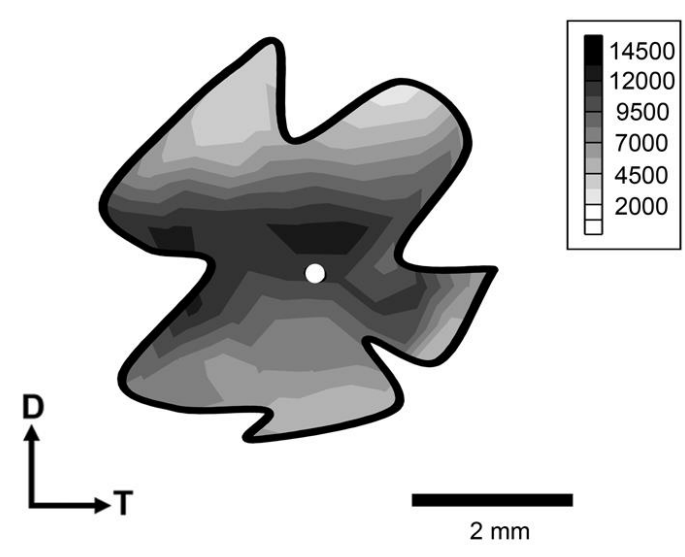

Fotorreceptores

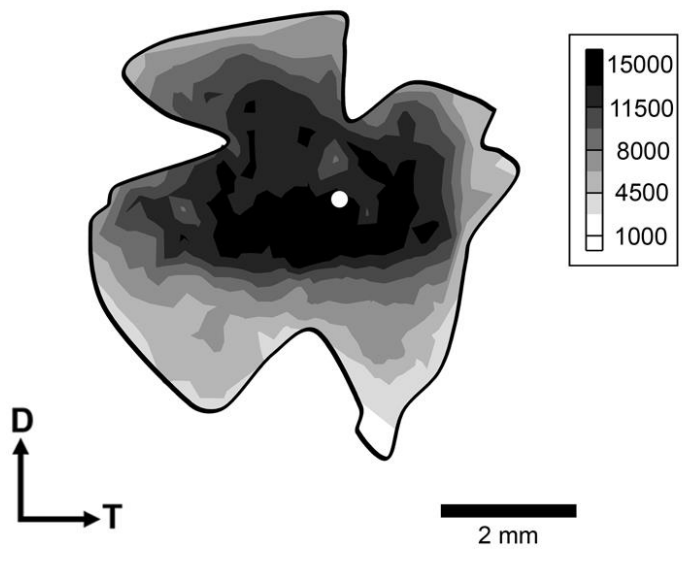

\section{Cones UV}

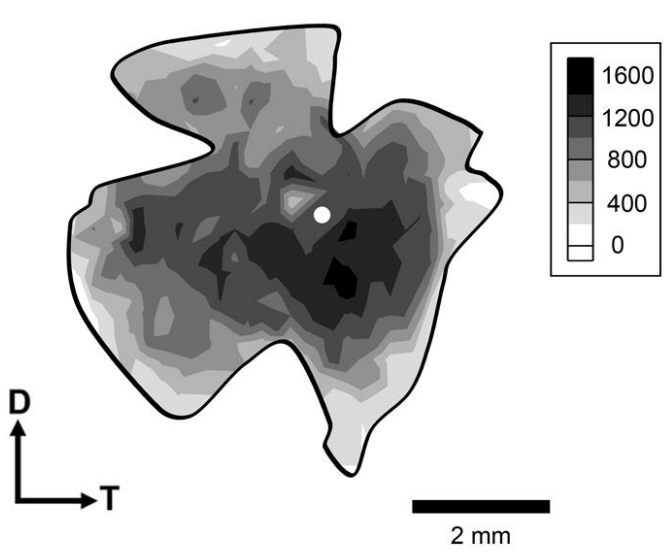

Figura 52. Mapas de isodensidade de neurônios de retinas de E. poecilogyrus, com faixa visual, para células da CCG e fotorreceptores, e area centralis de cones UV na região central. As barras de gradiente de cinza representam o número de células por $\mathrm{mm}^{2}$. A saída do nervo óptico está representada pelo ponto branco. $\mathrm{D}$, dorsal; $\mathrm{T}$, temporal. 


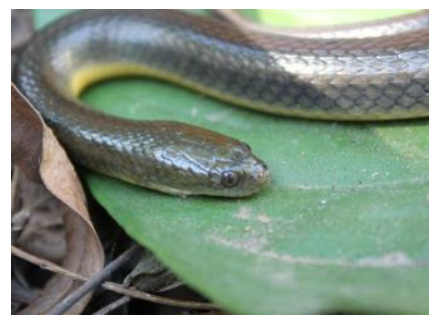

\section{Helicops modestus}

Espécie aquática, de hábito diurno e noturno.

Alimentação: peixes e anfíbios anuros.

Células da CCG

Fotorreceptores
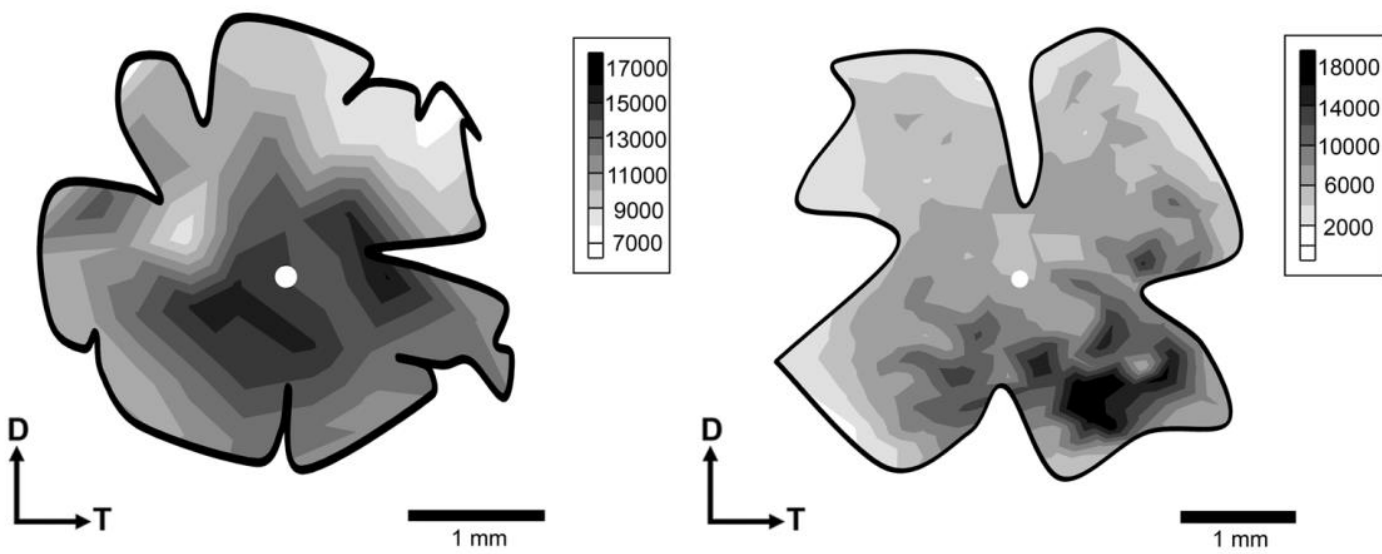

Cones L
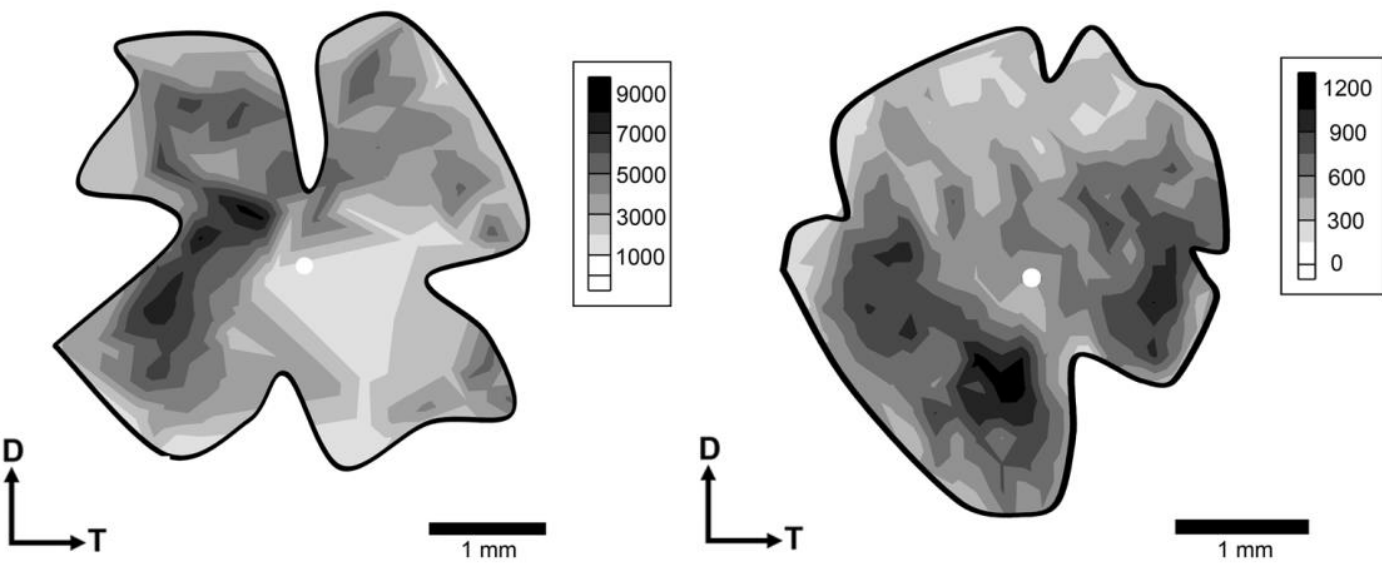

Figura 53. Mapas de isodensidade de neurônios de retinas de H. modestus, com area centralis na região central da retina para CCG e na região ventro-temporal da retina para os fotorreceptores. A distribuição de cones $\mathrm{L} / \mathrm{M}$ apresentou uma faixa vertical na região nasal da retina. A distribuição de cones UV mostrou uma area centralis anisotrópica na região ventral. As barras de gradiente de cinza ao lado de cada mapa representam o número de células por $\mathrm{mm}^{2}$. A saída do nervo óptico está representada pelo ponto branco. $\mathrm{D}$, dorsal; $\mathrm{T}$, temporal. 


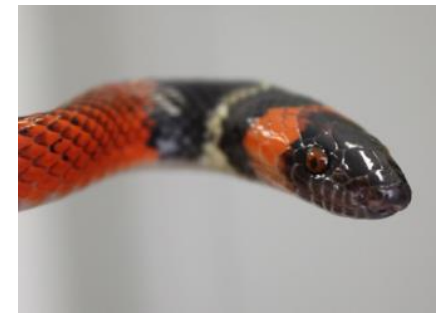

\section{Oxyrhopus guibei}

Espécie terrícola, de hábito noturno.

Alimentação: mamíferos e lagartos.
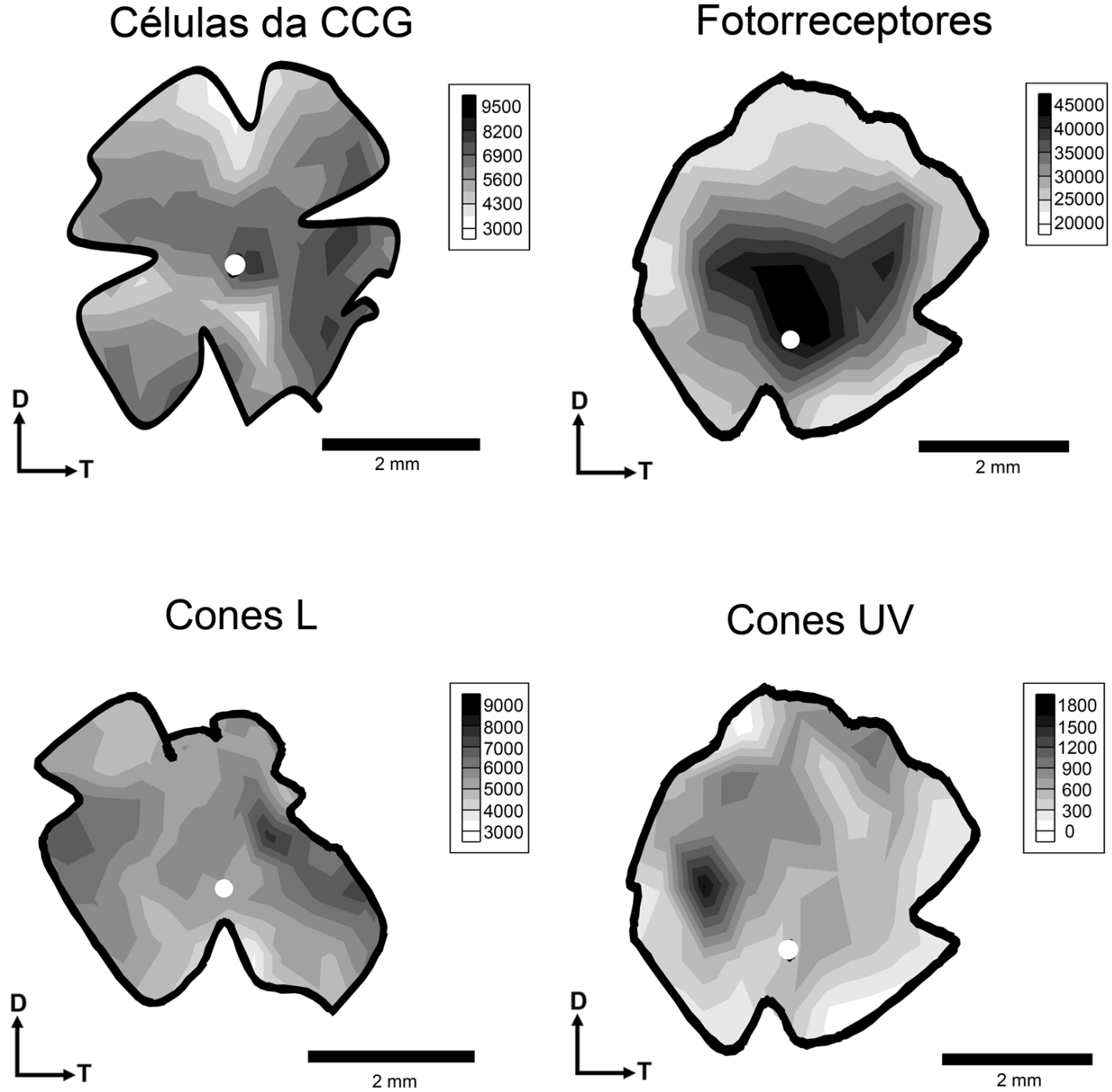

Figura 54. Mapas de isodensidade de neurônios de retinas de $O$. guibei, com uma distribuição difusa, sem formação de área ou faixa definidas para as células da CCG e para cones L/M. A distribuição de fotorreceptores apresentou uma area centralis na região central da retina, assim como a distribuição de cones UV, que apresentou uma área deslocada para a região nasal. As barras de gradiente de cinza representam o número de células por $\mathrm{mm}^{2}$. A saída do nervo óptico está representada pelo ponto branco. D, dorsal; T, temporal. 


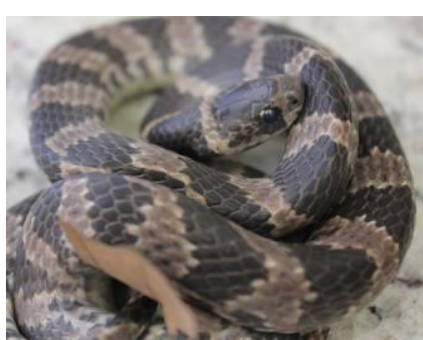

Células da CCG
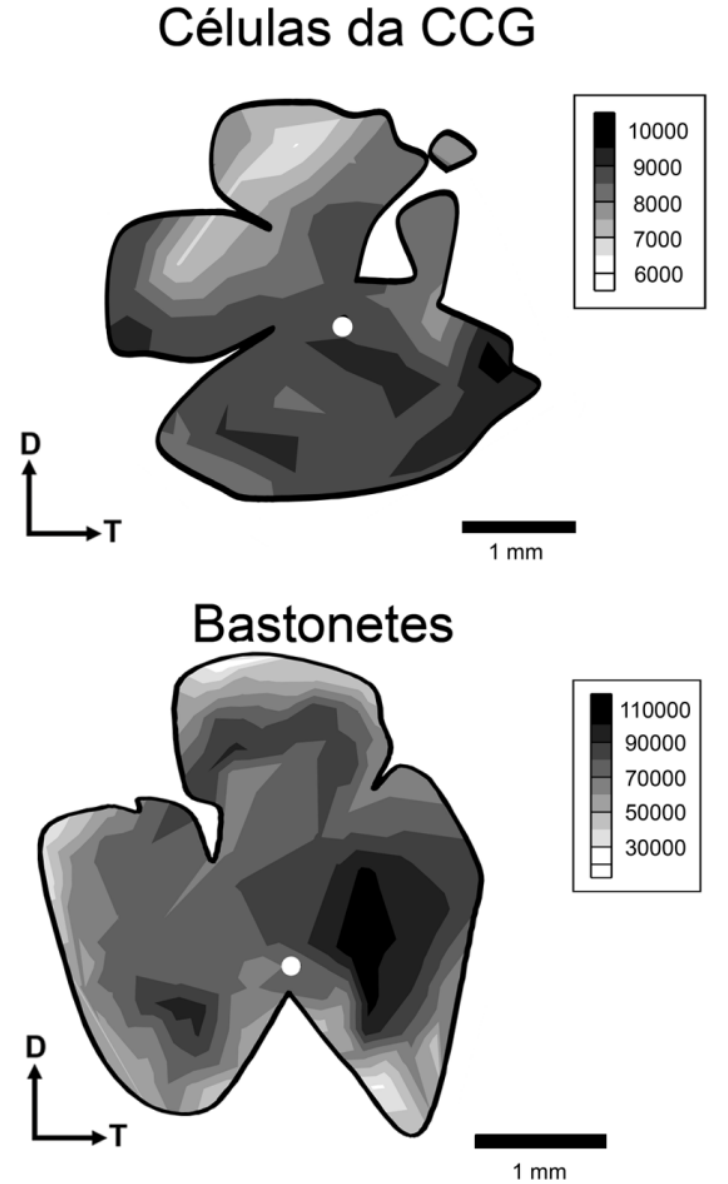

Cones L

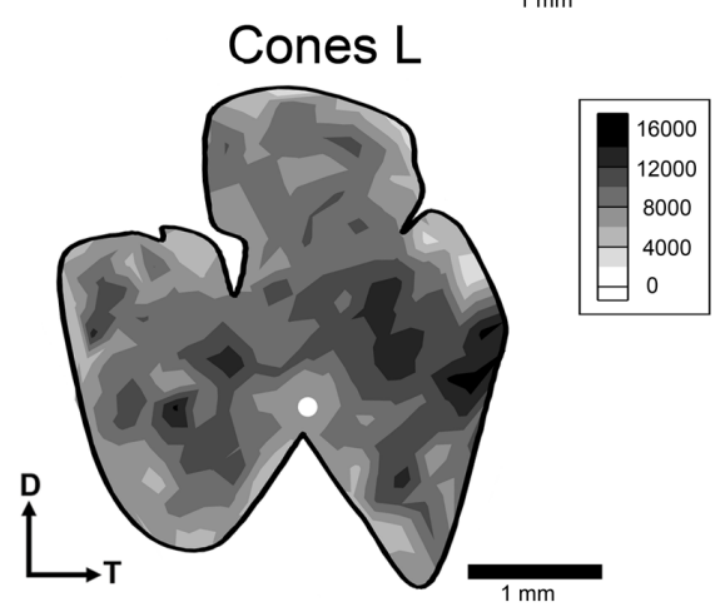

\section{Sibynomorphus mikanii}

Espécie terrícola, de hábito noturno.

Alimentação: moluscos.
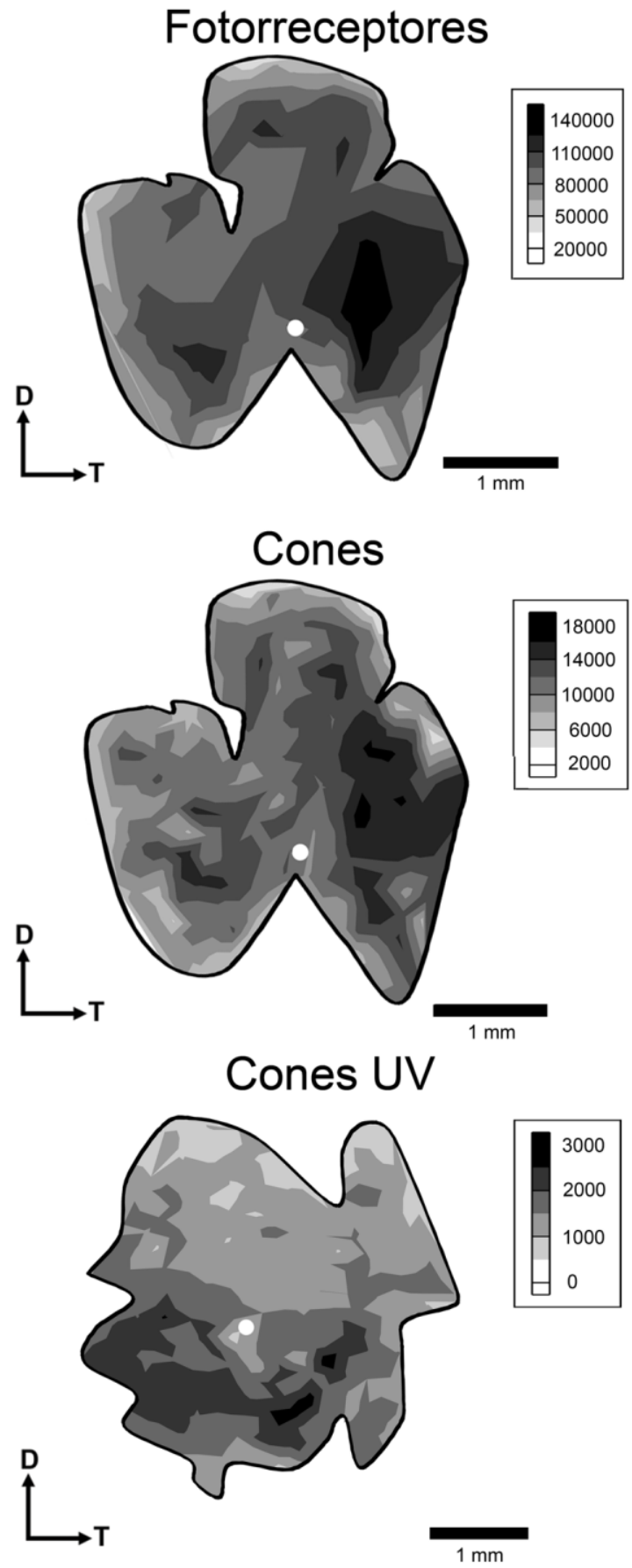

Figura 55. Mapas de isodensidade de neurônios de retinas de S. mikanii. O mapa de células da CCG apresentou uma distribuição relativamente difusa com área pouco definida na região ventral. Os mapas de fotorreceptores, juntamente com os mapas de cones, de bastonetes e de cones L/M, mostraram a formação de area centralis na região temporal da retina. Os cones UV apresentaram area centralis pouco definida na região ventral. As barras de gradiente de cinza ao lado de cada mapa representam o número de células por $\mathrm{mm}^{2}$. Saída do nervo óptico representada pelo ponto branco. $\mathrm{D}$, dorsal; $\mathrm{T}$, temporal. 


\section{Sibynomorphus neuwiedi}

Espécie terrícola e arborícola, de hábito noturno.

Alimentação: moluscos.

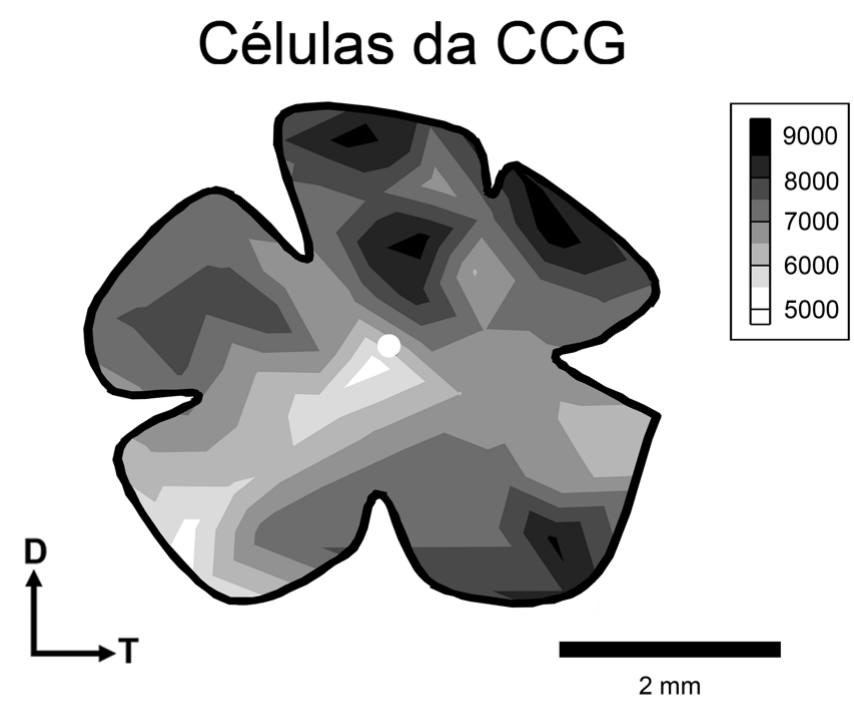

Fotorreceptores

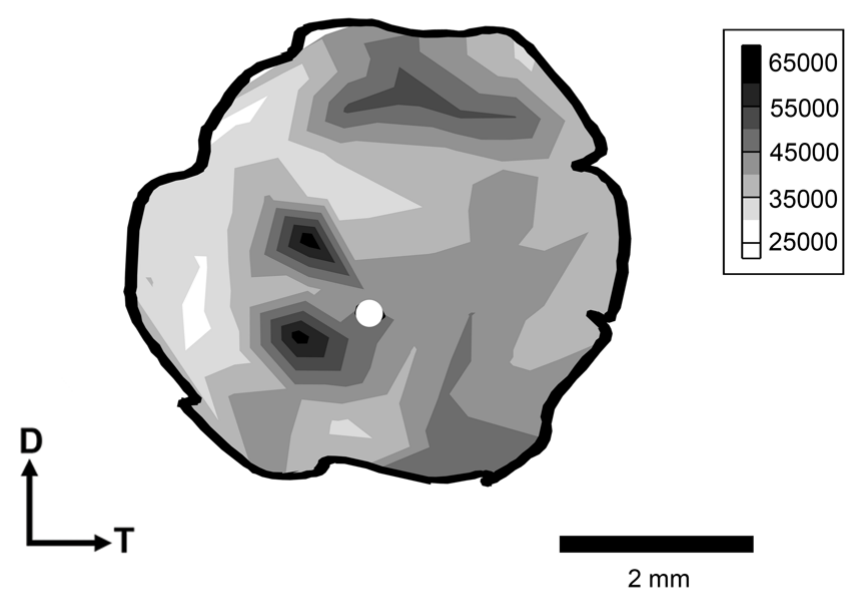

Figura 56. Mapas de isodensidade de neurônios de retinas de $S$. neuwiedi. O mapa de células da CCG apresentou uma distribuição relativamente difusa sem formação de uma área delimitada e maior densidade de células na região dorsal da retina. O mapa de fotorreceptores apresentou uma area centralis na região central da retina. As barras de gradiente de cinza representam o número de células por $\mathrm{mm}^{2}$. Saída do nervo óptico representada pelo ponto branco. D, dorsal; T, temporal. 


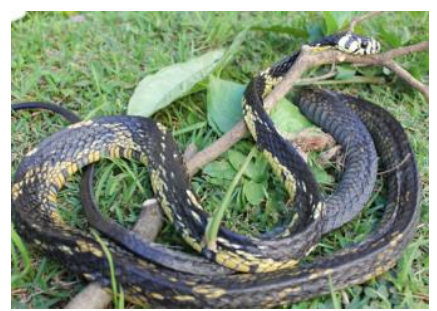

\section{Spilotes pullatus}

Espécie arborícola, de hábito diurno.

Alimentação: aves e mamíferos.

Células da CCG

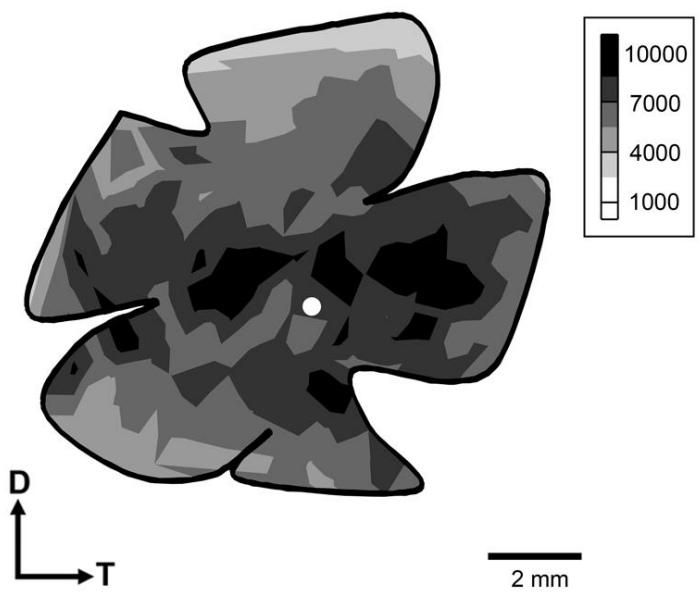

Fotorreceptores

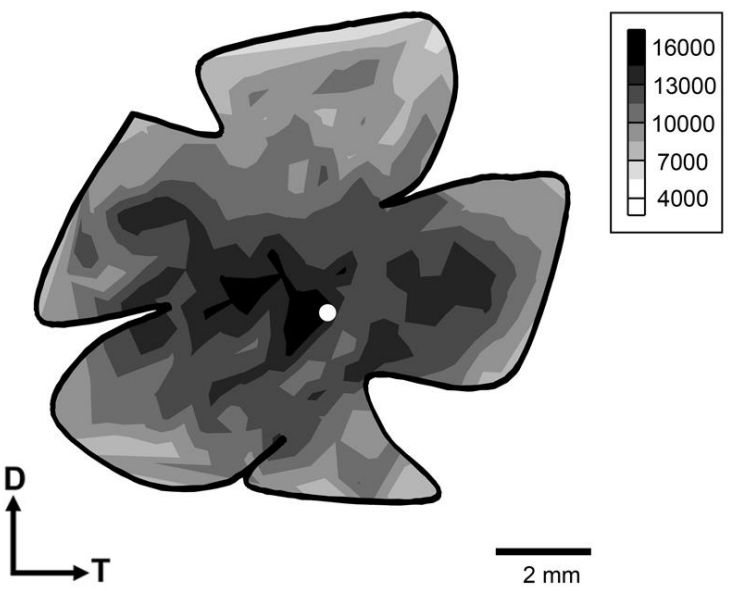

\section{Cones UV}

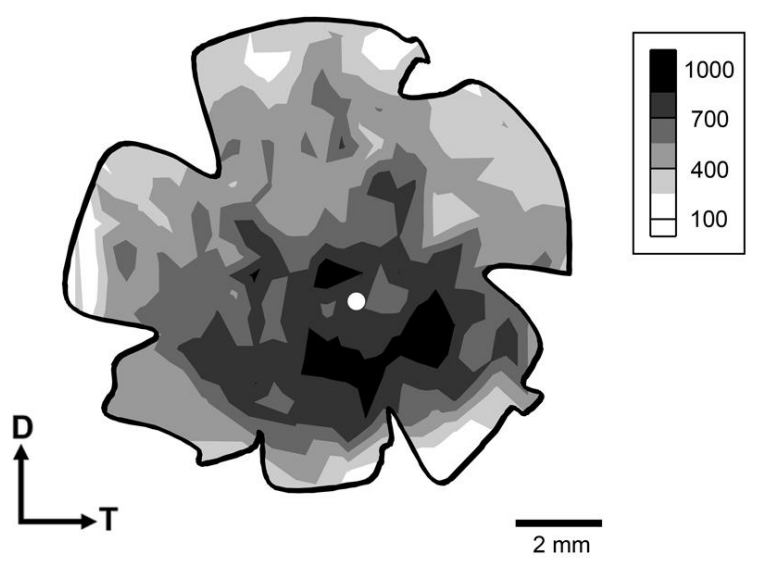

Figura 57. Mapas de isodensidade de neurônios de retinas de S. pullatus, com faixa visual pouco definida tanto para células da CCG como para fotorreceptores. Cones UV formaram uma area centralis na região ventral da retina. As barras de gradiente de cinza representam o número de células por $\mathrm{mm}^{2}$. A saída do nervo óptico está representada pelo ponto branco. $\mathrm{D}$, dorsal; $\mathrm{T}$, temporal. 


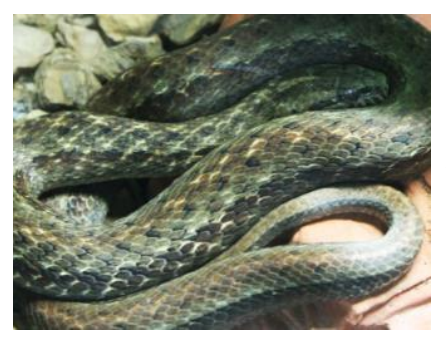

\section{Thamnodynastes strigatus}

Espécie semi-arborícola e terrícola, de hábito noturno.

Alimentação: anfíbios anuros e lagartos.

Células da CCG
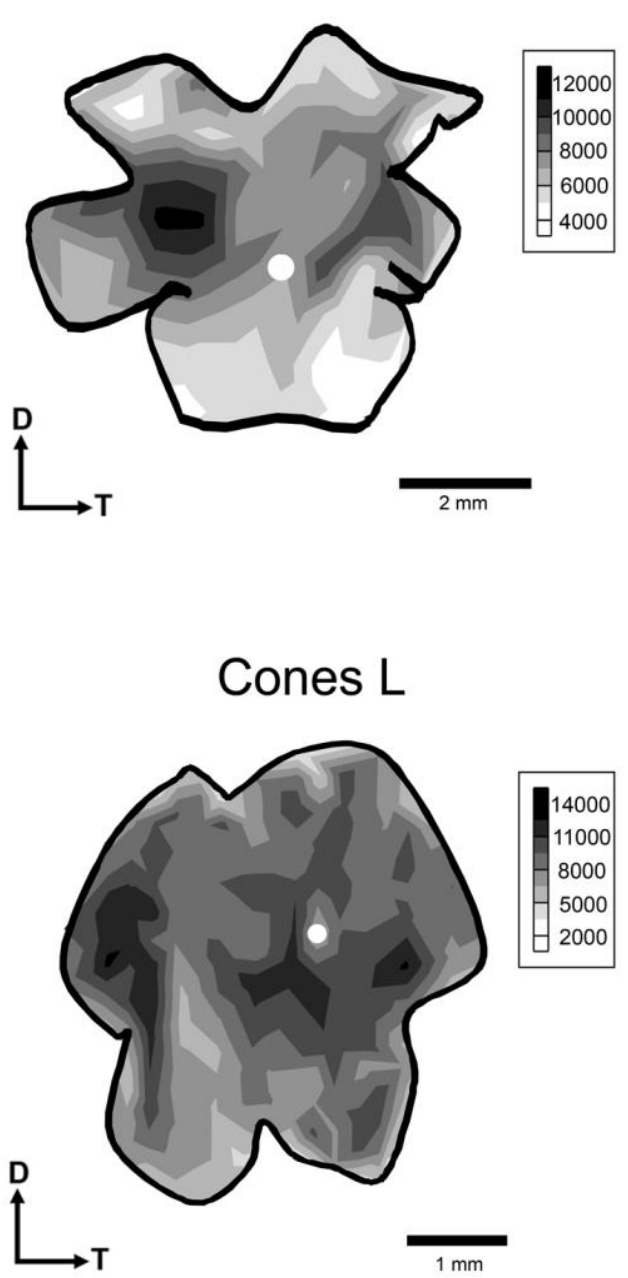

Fotorreceptores
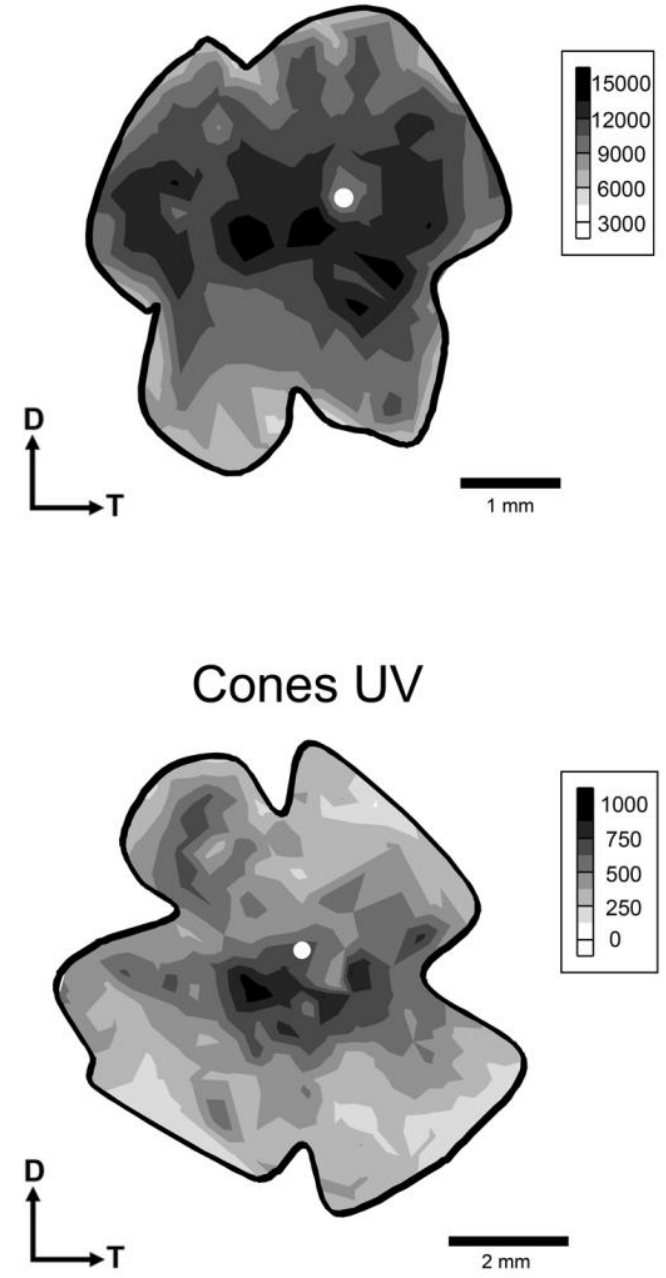

Figura 58. Mapas de isodensidade de neurônios de retinas de T. strigatus. Células da CCG apresentaram area centralis na região nasal da retina, enquanto fotorreceptores formaram uma faixa visual pouco definida. A população de cones $\mathrm{L} / \mathrm{M}$ se mostrou relativamente difusa com uma leve tendência à formação de faixa visual, acompanhando a distribuição de fotorreceptores. A população de cones UV apresentou distribuição do tipo area centralis localizada na região central. As barras de gradiente de cinza ao lado de cada mapa representam o número de células por $\mathrm{mm}^{2}$. A saída do nervo óptico está representada pelo ponto branco. $\mathrm{D}$, dorsal; $\mathrm{T}$, temporal. 


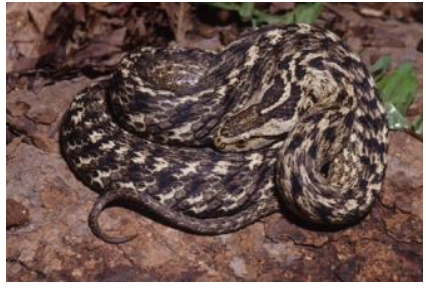

Otavio A.V. Marques

\section{Tomodon dorsatus}

Espécie terrícola, de hábito diurno.

Alimentação: moluscos.

Células da CCG

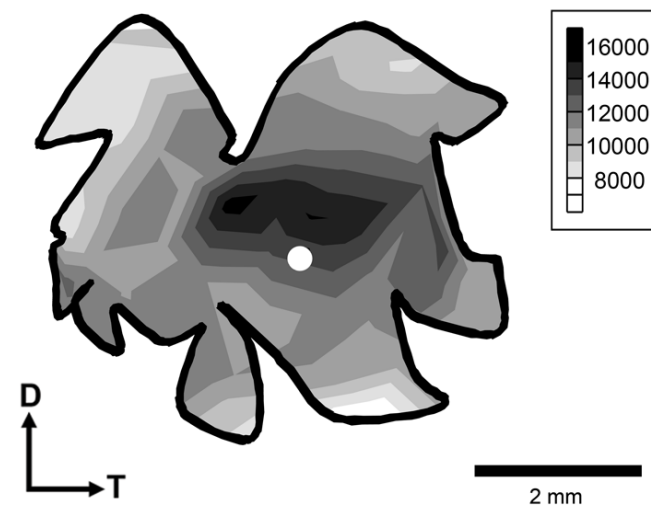

Cones L

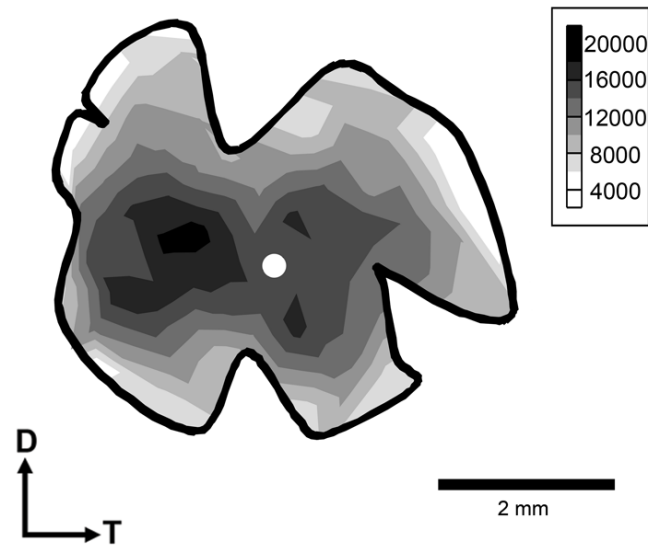

Fotorreceptores

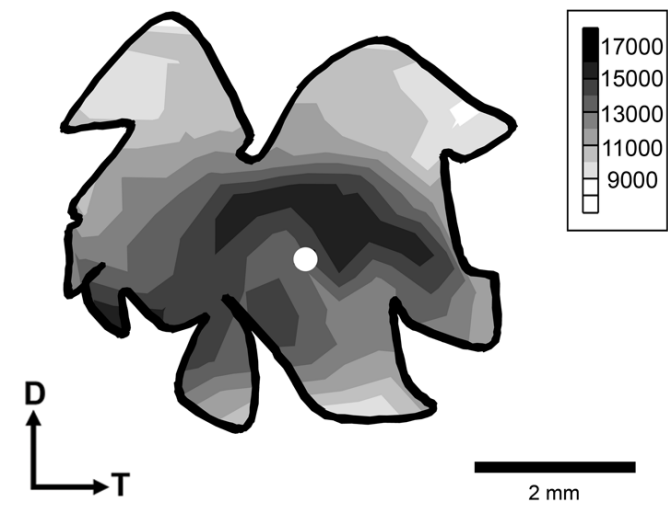

Figura 59. Mapas de isodensidade de neurônios de retinas de T. dorsatus, com distribuição do tipo faixa visual para células da CCG, fotorreceptores e cones L/M. Cones UV apresentaram distribuição do tipo area centralis com maior densidade na região ventral da retina. As barras de gradiente de cinza representam o número de células por $\mathrm{mm}^{2}$. A saída do nervo óptico está representada pelo ponto branco. $\mathrm{D}$, dorsal; $\mathrm{T}$, temporal. 


\section{DISCUSSÃO}

\subsection{Fotorreceptores e os pigmentos visuais de serpentes Caenophidia.}

As análises morfológicas das retinas de serpentes Caenophidia mostraram importantes adaptações do sistema visual ao ritmo circadiano das espécies. A grande quantidade de bastonetes observada em retinas de serpentes noturnas possibilita uma maior sensibilidade à luz e a realização de atividades em condições de baixa luminosidade. A presença de apenas cones em retinas de serpentes diurnas deve contribuir para uma maior capacidade de resolução espacial, dada a resposta mais rápida destas células (Jacobs et al., 1992). Retinas com apenas cones foram descrita para outras espécies de serpentes de hábitos diurnos, como espécies do gênero Thamnophis, serpentes marinhas da família Hydrophiidae e serpentes do gênero Philodryas (Walls, 1942; Underwood, 1967; 1970; Wong, 1989; Caprette, 2005; Hart et al., 2009; Hauzman et al., 2014).

\section{Densidade de fotorreceptores em retinas de serpentes diurnas e noturnas.}

A densidade de fotorreceptores teve grande variação entre os dois grupos de serpentes, diurnas e noturnas. Dentre as espécies de hábitos diurnos, os valores de densidade média variaram de aproximadamente 7.000 células $/ \mathrm{mm}^{2}$ em retina de $C$. bicarinatus, até cerca de 17.500 células $/ \mathrm{mm}^{2}$ em E. aesculapii, e a média das densidades de fotorreceptores de todas serpentes diurnas foi de aproximadamente $11.500 \pm 2.500$ células $/ \mathrm{mm}^{2}$. Estes valores foram semelhantes aos obtidos para serpentes do gênero Philodryas, com média de $15.011 \pm 1.669$ e $17.547 \pm 1.876$ células $/ \mathrm{mm}^{2}$ em $P$. olfersii e $P$. patagoniensis, respectivamente (Hauzman et al., 2014). Entre as espécies noturnas, a densidade de fotorreceptores teve maior variação, com 
aproximadamente 40.000 células $/ \mathrm{mm}^{2}$ em retinas de serpentes do gênero Atractus, até mais de 160.000 células $/ \mathrm{mm}^{2}$ em retinas de serpentes do gênero Dipsas. Nenhum outro estudo descreveu a densidade de fotorreceptores em retinas de serpentes Caenophidia de hábitos noturnos.

A densidade média de cones foi semelhante nas serpentes diurnas e noturnas, sendo que a elevada densidade estimada nas retinas de serpentes noturnas é atribuída ao alto grau de empacotamento dos bastonetes. Nas retinas em que cones e bastonetes foram quantificados separadamente, foi possível estimar a proporção de cada tipo de fotorreceptor. A população de bastonetes representou cerca de 73,5\% da população de fotorreceptores em uma retina de Atractus reticulatus, $88 \pm 0,1 \%$ em duas retinas de Sibynomorphus mikanii e $94 \pm 0,7 \%$ em três retinas de Dipsas bucephala. Esta variação de densidade pode estar associada a diferenças da taxa de atividade de cada espécie ao longo do dia. Serpentes consideradas predominantemente noturnas, por exemplo, podem apresentar atividades também em alguns períodos do dia (i.e. Hartman et al., 2009; Marques et al., 2001; Marques et al., 2009; Torello-Viera et al., 2012; Torello-Viera, 2014).

Em estudos comportamentais com serpentes mantidas em cativeiro, TorelloViera (2014) verificou a variação dos padrões de atividade de diferentes espécies ao longo do dia. A espécie fossorial Atractus pantostictus, por exemplo, apresentou $75 \%$ de suas atividades durante o período noturno, ou seja, 25\% das atividades desta espécie foram realizadas durante o dia. A serpente Sibynomorphus mikanii, por sua vez, apresentou $89 \%$ de suas atividades em período noturno, enquanto Dipsas bucephala teve predominância de atividade noturna (99\%), com raros eventos de atividade durante períodos de maior iluminação (Torello-Viera et al., 2012). A similaridade entre as taxas de atividade noturna de cada espécie e a densidade relativa de bastonetes descritas no 
parágrafo anterior, permite traçar uma relação entre os dados morfológicos da retina e as variações comportamentais das diferentes espécies de serpentes da subfamília Dipsadinae, que compreende os três gêneros citados. A densidade relativa de bastonetes em outras espécies de serpentes noturnas deve ser confrontada com estudos comportamentais para verificar se este tipo de relação é observado também em outros grupos.

Para todas as espécies analisadas, os dados morfológicos das retinas corroboraram informações da literatura quanto ao padrão de atividade, sendo que serpentes consideradas noturnas apresentaram cones e bastonetes, enquanto diurnas, apenas cones. A única exceção foi observada para serpentes do gênero Thamnodynates, amplamente classificadas na literatura como predominantemente noturnas, com base em registros de observação de atividade em campo (Bernarde et al., 2000; Marques et al., 2004; Vitt \& Vanilder, 1983; Strussmann \& Sazima, 1993; Bellini et al., 2013). A morfologia da retina de três diferentes espécies deste gênero, T. hypoconia, T. natererii e T. strigatus, apresentaram as mesmas características daquelas observadas para serpentes diurnas, baixa densidade de fotorreceptores, todos com segmento interno grande, a presença de apenas uma camada de núcleos na CNE, e ausência de marcação pela aglutinina WGA. De acordo com a morfologia da retina, serpentes deste gênero seriam classificadas como diurnas. Em seu estudo comportamental, Torello-Viera (2014) registrou atividade preferencialmente diurna para T. strigatus (74\%), e associou a atividade noturna relatada em estudos anteriores com a disponibilidade de alimento no ambiente (anfíbios anuros) e o deslocamento do pico de atividade do final da tarde, para início do período noturno. Desta forma, somando os dados morfológicos das retinas do presente estudo, com os registros de atividade em cativeiro obtidos por Torello-Viera 
(2014), propõe-se uma nova classificação de serpentes do gênero Thamnodynastes como de hábitos predominantemente diurnos.

A espécie semi-aquática e de alimentação generalista, Erythrolamprus miliaris, é descrita na literatura como de hábitos tanto diurnos quanto noturnos (Sazima \& Haddad, 1992; Marques et al., 2004). Entretanto, a ausência de bastonetes nas retinas desta espécie, aponta para o hábito preferencialmente diurno. Da mesma forma que em Thamnodynates, Torello-Viera (2014) observou predominância de atividade de E. miliaris no período diurno (95\%), com raros eventos de locomoção no período noturno, e associou as atividades noturnas observadas no ambiente com a disponibilidade de alimento (Shine, 1979; Gibbons \& Semlitsch, 1987; Martins et al., 2001; Bernarde \& Abe, 2006).

\section{O pigmento $R$ h1 de rodopsina e a teoria da transmutação.}

$\mathrm{Na}$ maioria dos vertebrados, os bastonetes contêm um pigmento visual rodopsina, do grupo Rh1, com pico de sensibilidade espectral em torno de $500 \mathrm{~nm}$ (Yokoyama, 2000). Em serpentes, os genes de pigmentos visuais foram sequenciados em apenas duas espécies do grupo Henophidia (serpentes "basais"), Python regius e Xenopeltis unicolor (Davies et al., 2009). Nas retinas destas espécies, com predominância de bastonetes, somado a dois tipos morfológicos de cones, três grupos de pigmentos visuais são expressos: o pigmento Rh1, de bastonetes, com pico de sensibilidade em $497 \mathrm{~nm}$; o LWS, de cones sensíveis a comprimentos de onda longos, com pico em $550 \mathrm{~nm}$; e o gene SWS1, de cones sensíveis a comprimentos de onda curtos, na faixa do UV, em 360 nm (Figura 60). Os pigmentos Rh2 e SWS2 não são expressos nas retinas destas espécies e Davies e colaboradores sugeriram que a perda dos dois pigmentos ocorreu antes da divisão dos grupos de serpentes atuais, e que, 
portanto, serpentes "avançadas" (Caenophidia) também não teriam estes dois genes expressos nas retinas.

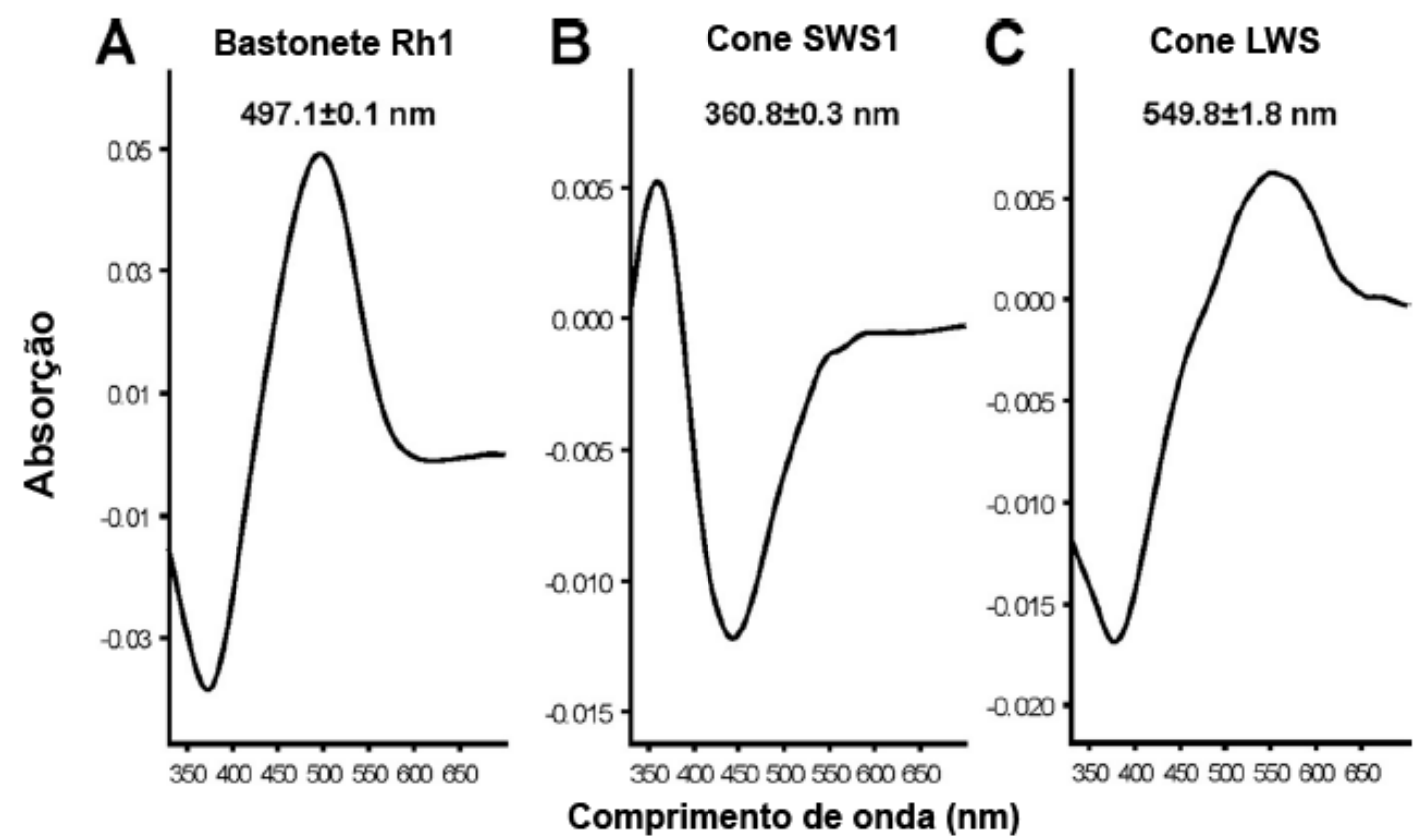

Figura 60. Espectro de absorção dos pigmentos visuais Rh1 (A), SWS1 (B) e LWS (C) de X. unicolor, regenerado in vitro com 11-cis-retinal (modificado de Davies et al., 2009).

Nas serpentes Caenophidia analisadas neste estudo, os mesmos três genes de pigmentos visuais foram amplificados e sequenciados em todas as espécies. O pigmento Rh1 de bastonetes é expresso em retinas de serpentes tanto noturnas quanto diurnas, mesmo na ausência de um fotorreceptor do tipo bastonete em diurnas, indicando que um dos tipos morfológicos de cones estaria "expressando" o pigmento visual de bastonete.

Ao observar a variabilidade das retinas de serpentes e lagartos diurnos e noturnos, Gordon Walls sugeriu que cones e bastonetes poderiam ser interconversíveis em um processo que ele chamou de transmutação. Walls (1942) propôs que a retina de serpentes e de lagartos noturnos, com cones e bastonetes, teria evoluído a partir de um padrão ancestral diurno, de apenas cones, e um dos fotorreceptores teria adquirido características morfológicas e fisiológicas de bastonetes, como adaptação ao novo hábito noturno nestes grupos de Squamata. Tal teoria foi corroborada, por exemplo, 
com estudos da genética dos pigmentos visuais do lagarto noturno Tokay gecko, no qual o pigmento visual Rh1 não é expresso, e o fotopigmento sensível a comprimentos de onda médios, Rh2, de cones, é expresso em um fotorreceptor do tipo bastonete (Yokoyama \& Blow, 2001). Em serpentes, entretanto, o pigmento Rh1 de bastonete está presente nas retinas de espécies basais, indicando que o padrão de retina ancestral seria provido tanto de cones quanto de bastonetes. Desta forma, as retinas de serpentes Caenophidia diurnas, com apenas cones, teriam divergido a partir do padrão ancestral, noturno ou crepuscular, e o pigmento Rh1 nestas espécies, expresso em um fotorreceptor com características de cone, poderia estar contribuindo para a visão diurna, com aumento do poder de resolução espacial e/ou da capacidade de discriminação cromática.

A presença de quatro classes morfológicas de cones nas retinas de diferentes espécies de serpentes diurnas, Thamnophis sirtalis (Sillman et al., 1997), Lapemis curtus, Acalyptophis peronii (Hart et al., 2012), Philodryas olfersii e P. patagoniensis (Hauzman et al., 2014), fortalece a ideia de que um dos cones, ausente em serpentes noturnas dos grupos Henophidia (Sillman et al., 1999) e Caenophidia, possa ter evoluído a partir de um bastonete. Em T. sirtalis, Sillman et al. (1997) classificou os cones quanto à sua morfologia e pico de sensibilidade espectral: cones simples grandes e cones duplos com $\lambda_{\max }$ de $554 \mathrm{~nm}$, cones simples pequenos com $\lambda_{\max }$ de $360 \mathrm{~nm}$, e um segundo grupo de cones simples pequenos com $\lambda_{\max }$ de $482 \mathrm{~nm}$. Dado o pico de sensibilidade espectral e a ausência deste segundo grupo de cones simples pequenos em retinas de serpentes Henophidia, este quarto tipo de fotorreceptor seria um possível candidato da teoria da transmutação, em um sentido inverso daquele proposto por Walls (1934). 


\section{Genética do pigmento Rh1}

Mutações nos sete resíduos de aminoácidos responsáveis pelo deslocamento espectral do pigmento Rh1 ocorreram diversas vezes em diferentes estágios da evolução dos vertebrados (Yokoyama, 2000). Nas serpentes estudadas, o pigmento Rh1 sequenciado apresentou três diferentes combinações de aminoácidos nos sítios específicos. A combinação dos resíduos DEMHWAA nos sítios 83, 122, 207, 211, 265, 292 e 295, gera um $\lambda_{\max }$ de $500 \mathrm{~nm}$ e foi observada nas espécies noturnas, Dipsas petersi, Oxyrhopus guibei, Sibynomorphus mikanii e S. neuwiedii e na serpente noturna do grupo Henophidia Boa constrictor. A mutação D83N que leva ao deslocamento espectral de até $6 \mathrm{~nm}$ para o azul, foi observada na espécie noturna e fossorial Atractus reticulatus, e nas serpentes Henophidia Epicrates crassus, Xenopeltis unicolor (FJ497233) e Python regius (FJ497236). A rodopsina de X. unicolor apresentou $\lambda_{\max }$ de 497 - 499 nm (Davies et al., 2009), e de P. regius um $\lambda_{\max }$ de 494 nm (Silman et al., 1999), como esperado considerando a combinação de aminoácidos do pigmento Rh1. O perfil NEMHWSA, com as mutações D83N e A292S pode levar ao deslocamento espectral para o azul de até $16 \mathrm{~nm}$, gerando um $\lambda_{\max }$ de $484 \mathrm{~nm}$, e foi observado em todas as espécies de serpentes de hábitos diurnos estudadas, e em nenhuma espécie de hábitos noturnos (Figura 61). Na serpente diurna Thamnophis sirtalis, a segunda classe de cones simples pequenos, com $\lambda_{\max }$ em $482 \mathrm{~nm}$ (Sillman et al., 1997) deve corresponder ao valor obtido para a rodopsina $\mathrm{Rh} 1$ das serpentes diurnas, com as mutações D83N e A292S. 


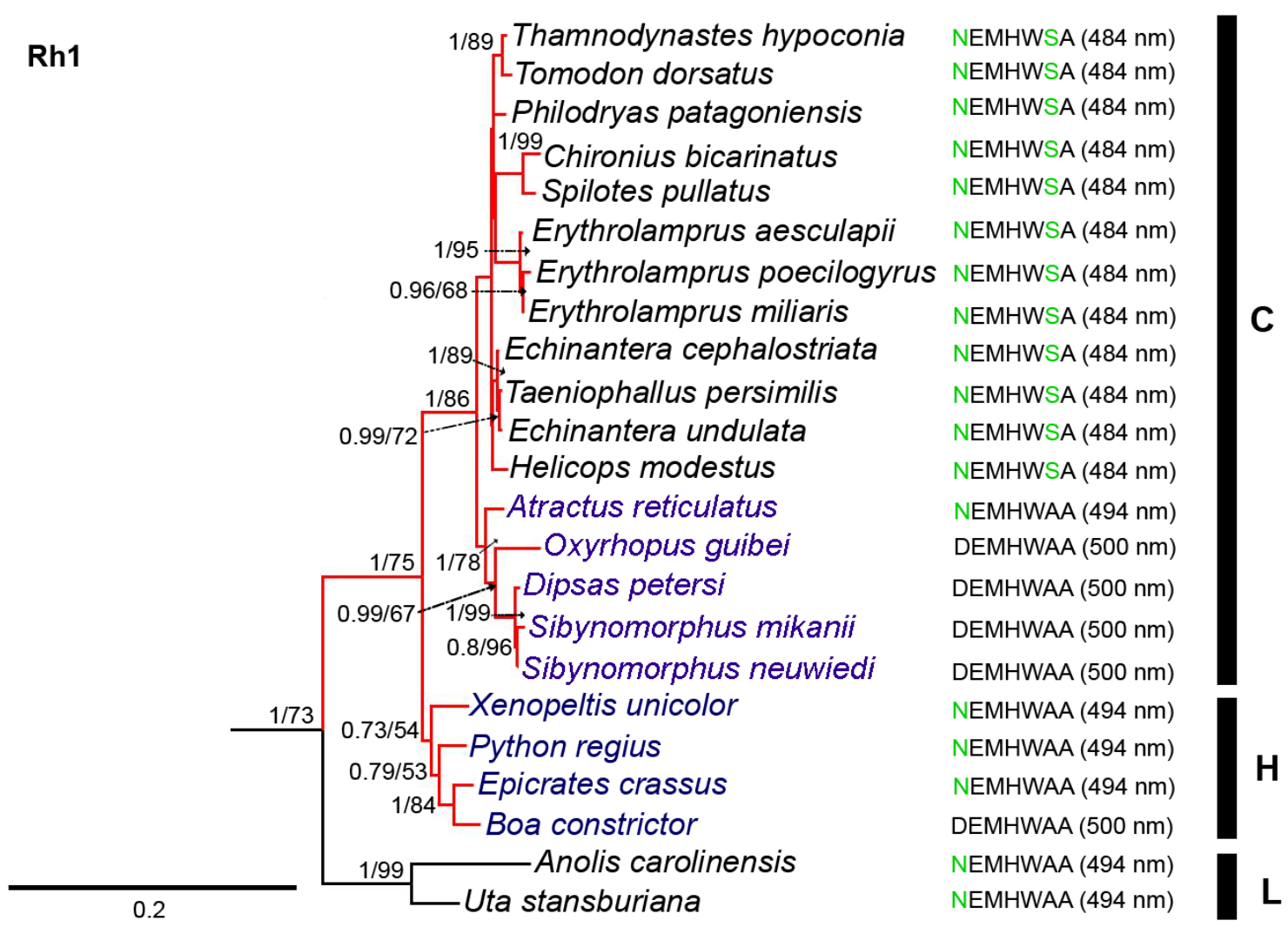

Figura 61. Análise filogenética das sequências de nucleotídeos do pigmento visual Rh1 de serpentes e lagartos, construída pelo método de Máxima Verossimilhança. Os valores apresentados correspondem às probabilidades bayesianas e aos suportes de bootstrap. Grupo das serpentes destacado em vermelho; espécies de hábitos noturnos representadas em azul. As sequências de aminoácidos relevantes para o deslocamento espectral do fotopigmento Rh1 estão descritas para cada espécie, com as mutações D83N e A292S em destaque (verde), e ao lado entre parênteses os valores do pico de sensibilidade espectral estimados a partir da sequência de aminoácidos. C, Caenophidia; H, Henophidia; L, lagartos. A barra de escala representa o número de substituições de nucleotídeos por sítio.

O deslocamento do pico de sensibilidade espectral do pigmento Rh1 para o azul foi observado em diferentes grupos de vertebrados, como peixes teleósteos de grandes profundidades (Hunt et al., 2001), o celacanto (Yokoyama et al., 1999), e alguns mamíferos marinhos (Fasick \& Robinson, 2000), como adaptação às condições fóticas do ambiente, porém em nenhum dos casos foi relatada a sua expressão em fotorreceptor do tipo cone. A perda do gene Rh2 de cones, pelo ancestral das serpentes, como sugerido por Davies et al. (2009), é compensada nestas espécies diurnas pelo ganho de um cone expressando o gene Rh1, com sensibilidade no comprimento de onda médio. Desta forma, este pigmento estaria contribuindo para a capacidade de discriminação de 
diferentes comprimentos de onda, e somado aos pigmentos L e UV, que serão descritos a seguir, serpentes Caenophidia diurnas podem ter adquirido a capacidade de visão tricromata.

A respeito da filogenia observada para o gene Rh1, o clado formado por serpentes Caenophidia noturnas (A. reticulatus, D. petersi, O. guibei, S. mikanii, S. neuwiedi) apresentou um elevado suporte de bootstrap, porém diverge das filogenias aceitas para estes grupos de serpentes (Zaher et al., 2009; Grazziotin et al., 2012; Pyron et al., 2013). A serpente Xenodontinae O. guibei formou um grupo monofilético juntamente com serpentes Dipsadinae, apontando para a forte pressão seletiva exercida sobre o gene Rh1 em serpentes de hábitos noturnos e diurnos.

\section{A população de cones grandes e cones duplos e o pigmento sensível ao comprimento de onda longo (LWS).}

Dois grupos de cones puderam ser diferenciados e quantificados nas retinas de serpentes diurnas e noturnas. Cones marcados pelo anticorpo anti-opsinas L/M representaram a maior parte da população de fotorreceptores em retinas de serpentes diurnas e a maior parte da população de cones, em retinas de noturnas. Um menor número de cones simples pequenos foram marcados pelo anticorpo contra opsinas de cones $\mathrm{S}$, em retinas de serpentes diurnas e noturnas.

A densidade média de cones marcados pelo anticorpo anti-opsinas L/M variou de 4.000 células $/ \mathrm{mm}^{2}$ na serpente noturna $O$. guibei, até cerca de 11.000 células $/ \mathrm{mm}^{2}$ na diurna T. dorsatus, mas não foi observada correlação entre a variação de densidade média deste tipo de cone e o padrão de atividade das espécies. Serpentes diurnas tiveram um valor de população total deste tipo celular significativamente maior que as noturnas, mas dada a similaridade dos valores de densidade média entre os dois grupos 
de serpentes, pode-se dizer que esta variação foi decorrente da maior área das retinas de serpentes diurnas.

Em retinas de serpentes diurnas, aproximadamente $50 \%$ da população de fotorreceptores marcados pelo anticorpo contra opsinas L/M era de cones duplos, enquanto a outra metade era de cones simples grandes. Nas serpentes noturnas, todos os cones marcados por este anticorpo eram cones simples grandes, e nenhum cone duplo foi observado. Cones duplos são definidos como dois fotorreceptores fundidos e que podem ser opticamente e/ou eletricamente acoplados (Marchiafava, 1985; Smith et al., 1985). Estes tipos de cones estão presentes nas retinas da maioria dos grupos de vertebrados, com exceção de mamíferos placentários e elasmobrânquios (Walls, 1942; Ali \& Anctil, 1976; Ebrey \& Koutalos, 2001). Sua função foi associada em diversas espécies com tarefas acromáticas, como a visão de contraste de luminância, visão de movimento ou a percepção de luz polarizada (Boehlert, 1978; Lythgoe, 1979; Cameron \& Pugh, 1991; McFarland, 1991; Hawryshyn et al., 2003; Schaerer \& Neumeyer, 1996; Campenhausen \& Kirschfeld, 1998). A partir de estudos com diferentes espécies de peixes e aves, foi proposto que os sinais dos dois membros dos cones duplos são somados na retina e não são enviados separadamente para o cérebro (Marshall \& Vorobyev, 2003; Marshall et al., 2003), e que este tipo de cone não participaria, portanto, da capacidade de discriminação cromática (Maier \& Bowmaker, 1993; Vorobyev \& Osorio, 1998; Goldsmith \& Butler, 2003). Entretanto, Pignatelli e colaboradores (2010), verificaram evidências de que em uma espécie de peixe, Rhinecanthus aculeatusteria, os dois membros dos cones duplos, cada um contendo um pigmento visual distinto, são usados na visão de cores como canais espectrais independentes. 
Em estudos utilizando a técnica de microespectrofotometria, foi verificado que o membro principal e o acessório de cones duplos da serpente Thamnophis sirtalis, possuem pigmento visual com o mesmo pico de sensibilidade espectral, na faixa de comprimentos de onda longos, com $\lambda_{\max }$ de $554 \mathrm{~nm}$ (Sillman et al., 1997), e de 555 a $559 \mathrm{~nm}$ em Acalyptophis peronii e Lapemis curtus (Hart et al., 2012). Nas serpentes analisadas neste estudo, o anticorpo anti-opsinas L/M marcou os segmentos externos de ambos os membros dos cones duplos, indicando a presença de um único pigmento visual e a incapacidade de discriminação cromática entre eles. Desta forma, a somação do sinal de membros individuais de cones duplos deve beneficiar a visão de luminância e aumentar a capacidade de detecção de alvos em contraste contra o fundo (Lythgoe, 1979; Lythgoe \& Partridge, 1989; Marshall \& Vorobyev, 2003; Marshall et al., 2003), importante para as espécies de serpentes diurnas.

\section{Genética do pigmento LWS}

As análises genéticas dos pigmentos visuais das serpentes estudadas, revelaram a expressão do gene LWS em todas as espécies. Avaliando a sequência de aminoácidos deste pigmento e considerando a "regra dos cinco sítios" (Yokoyama \& Radlwimmer, 1999), foram observadas 4 possíveis combinações dos sítios de relevância para o deslocamento espectral. As serpentes noturnas da subfamília Dipsadinae (gêneros Atractus, Dipsas e Sibynomorphus) apresentaram a combinação AHYAA, com o maior deslocamento para o azul e $\lambda_{\max }$ de $537 \mathrm{~nm}$. Serpentes da tribo Tachymenini, Tomodon e Thamnodynastes apresentaram a combinação AHFTA, com $\lambda_{\max }$ de $543 \mathrm{~nm}$. A serpente noturna Oxyrhopus guibei e a diurna Erythrolamprus poecilogyrus apresentaram o perfil AHYTA, com $\lambda_{\max }$ de $553 \mathrm{~nm}$, e as demais espécies, todas diurnas e com representantes das famílias Colubridae e Dipsadidae, apresentaram o perfil SHYTA, com o maior deslocamento para o vermelho e $\lambda_{\max }$ de $560 \mathrm{~nm}$ (Figura 62). 


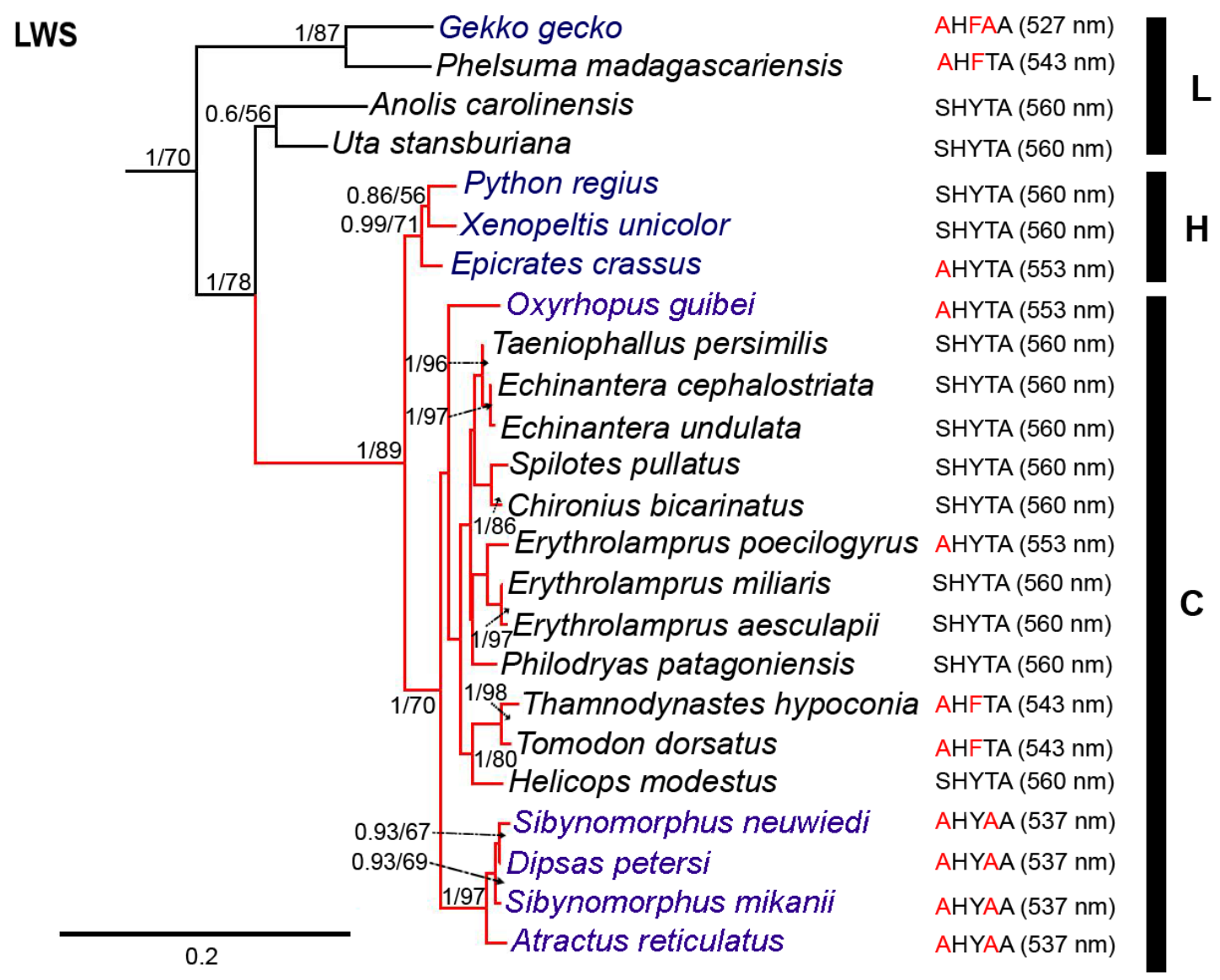

Figura 62. Análise filogenética das sequências de nucleotídeos do pigmento visual LWS de serpentes e lagartos (grupo externo), construída pelo método de Máxima Verossimilhança. Os valores apresentados correspondem às probabilidades bayesianas e aos suportes de bootstrap. Grupo das serpentes destacado em vermelho; espécies de hábitos noturnos representadas em azul. As sequências de aminoácidos relevantes para o deslocamento espectral do fotopigmento LWS estão descritas para cada espécie, com as mutações S180A, Y277F e T285A em destaque (vermelho), e ao lado entre parênteses os valores do pico de sensibilidade espectral estimados a partir da sequência de aminoácidos. C, Caenophidia; H, Henophidia; L, lagartos. A barra de escala representa o número de substituições de nucleotídeos por sítio.

O gene LWS foi amplificado e sequenciado em apenas duas espécies de serpentes do grupo Henophidia, Python regius e Xenopeltis unicolor (Davies et al., 2009), e a combinação dos aminoácidos apresentou o perfil SHYTA, que corresponde a um pico de sensibilidade de $560 \mathrm{~nm}$ (Figura 62). Entretanto, as análises de microespectrofotometria realizadas neste mesmo estudo revelaram um pico de sensibilidade de $\lambda_{\max }$ de $551 \mathrm{~nm}$. Os autores sugerem, portanto, que outros resíduos não identificados estariam contribuindo para o deslocamento espectral em direção a comprimentos de onda mais curtos no pigmento visual LWS de serpentes. No presente 
trabalho foram considerados os deslocamentos propostos para outros vertebrados, conforme descrito por Yokoyama \& Radlwimmer (1999), e registros fisiológicos da sensibilidade espectral deste pigmento visual de serpentes Caenophidia são necessários para confirmar a influência de outros resíduos para o deslocamento do $\lambda_{\max }$.

A variação das combinações de aminoácidos do pigmento LWS parece seguir a filogenia de serpentes, com prevalência da combinação SHYTA nas Caenophidias diurnas, e com a mutação Y277F apenas na tribo Tachymenini (T. dorsatus e $T$. strigatus). A única exceção ao grupo foi a mutação S180A em duas espécies, O. guibei e E. poecilogyrus. O maior deslocamento para o azul observado nas serpentes Dipsadinae pode estar relacionado com o hábito noturno e uma compensação da taxa de ruído proporcionada pela isomerização térmica, que é indistinguível pelo sistema visual da absorção de fótons pelos pigmentos visuais (Osorio \& Vorobyev, 2005).

O pico de sensibilidade espectral de um pigmento visual reflete uma compensação entre a necessidade de captura de fótons e o efeito do ruído de escuro, que corresponde à taxa de ativação espontânea das moléculas de fotopigmentos, por isomerização térmica (Barlow, 1957). Esta ativação espontânea aumenta juntamente com o aumento do pico de sensibilidade espectral do fotopigmento, dado que o limite de energia para a ativação térmica diminui com o aumento do seu $\lambda_{\max }$ (Barlow, 1957). Como consequência, fotopigmentos com pico de sensibilidade espectral em comprimentos de onda longos (de cones L) sofrem mais ativação térmica espontânea do que aqueles sensíveis a comprimentos de onda curtos (de cones S) (Rieke \& Baylor, 2000). Quando a taxa de sinal-ruído é determinada apenas pela absorção de fótons (desconsiderando a isomerização térmica), o valor ótimo de $\lambda_{\max }$ do fotopigmento tenderá a ser em favor da máxima captura de fótons disponíveis no ambiente (Osorio \& 
Vorobyev, 2005). O espectro de iluminação durante a noite é muito similar ao da luz do dia (Henderson, 1977), e um pigmento com $560 \mathrm{~nm}$ maximiza a captura de fótons no período diurno ou noturno (Osorio \& Vorobyev, 2005). Entretanto, o ruído de escuro é mais relevante em baixas iluminações, e por isso os fotopigmentos de rodopsina tem um pico $\lambda_{\max }$ em torno de $500 \mathrm{~nm}$ e não de $560 \mathrm{~nm}$. Dado que os cones apresentam maior taxa de isomerização térmica do que bastonetes (Lamb \& Simon, 1977; Schnapf et al., 1990), é possível que o deslocamento espectral do fotopigmentos LWS de serpentes noturnas para comprimentos de ondas mais curtos, com relação aos fotopigmentos LWS de serpentes diurnas, seja um mecanismo de redução da taxa de isomerização térmica nestas opsinas.

\section{A população de cones simples pequenos e o pigmento sensível ao comprimento de onda curto (SWS1).}

Nas retinas de ambos os grupos de serpentes, diurnas e noturnas, uma pequena quantidade de cones simples pequenos foi marcada pelo anticorpo JH455, produzido a partir de cones sensíveis ao comprimento de onda curto de humanos (Nathan et al., 1986). Tal pigmento em mamíferos placentários, pertence ao grupo de opsinas SWS1, com variação espectral que vai do ultravioleta em $355 \mathrm{~nm}$, até o violeta, em $455 \mathrm{~nm}$ (Yokoyama, 2000). A similaridade entre as sequências de aminoácidos dos anticorpos e as sequências das opsinas de serpentes descritas na literatura (Nathan et al., 1986; Davies et al., 2009) e das sequências analisadas neste estudo, indicam que o anticorpo utilizado marcou de forma específica e diferenciada a população de cones sensíveis ao comprimento de onda curto nas serpentes Caenophidia.

A sensibilidade na faixa de luz UV em $360 \mathrm{~nm}$, foi descrita para uma espécie de serpentes Caenophidia, T. sirtalis (Sillman et al., 1997) e três espécies de serpentes 
Henophidia, P. regius (Sillman et al., 1999; Davies et al., 2009), Boa constrictor imperator (Sillman et al., 2001) e X. unicolor (Davies et al., 2009). Em serpentes marinhas, a sensibilidade deste fotopigmento teve um deslocamento para o violeta, com pico de sensibilidade em $430 \mathrm{~nm}$, uma adaptação ao ambiente fótico neste grupo (Hart et al., 2012).

A importância ecológica da sensibilidade UV em serpentes foi relacionada com a estratégia de forrageamento e busca por alimento, através da visualização de rastros de fezes e urina de roedores que refletem luz UV (Desjardins et al., 1973; Viitala et al., 1995), e/ou a busca por parceiros para acasalamento, pela visualização de rastros de feromônios (Ford \& Low, 1984), que absorvem luz ultravioleta (Alberts, 1989). Desta forma, poderia se esperar uma maior densidade de cones UV em machos de serpentes quando comparado a fêmeas. O gráfico apresentado na Figura 44 dos resultados mostra que nas serpentes Dipsas, Helicops e Thamnodynates, os machos apresentaram uma densidade levemente maior do que fêmeas, enquanto o oposto foi observado em Tomodon e Oxyrhopus, espécie na qual a fêmea apresentou uma densidade quase 3,5 vezes maior de cones UV do que o macho. A considerável diferença de densidade de cones UV entre um macho e uma fêmea de Oxyrhopus guibei pode estar relacionada aos seus hábitos alimentares somado à sua estratégia reprodutiva. Fêmeas de serpentes da tribo Pseudoboini são em média maiores e atingem maturidade sexual com maior tamanho corporal do que os machos (Pizzatto \& Marques, 2002; Orofino et al., 2010). Desta forma, para atingir um maior tamanho corporal, as fêmeas devem ter uma maior necessidade de forrageamento e busca por alimentos (roedores e lagartos), e a densidade elevada de cones UV pode favorecer a localização de rastros deixados por suas presas. Um aumento do número amostral de machos e fêmeas desta espécie é necessário para confirmar tal hipótese. Em serpentes do gênero Philodryas o macho apresentou uma 
maior população de cones UV (29,165 células), quando comparado às fêmeas $(17,065 \pm$ 1,582 células), o que sugere que as diferenças da densidade deste tipo de cone em retinas de machos e fêmeas podem refletir as variações das estratégias alimentares, tipos de presas, e estratégias reprodutivas de cada espécie.

A densidade média de cones UV foi significativamente maior em serpentes de hábitos noturnos, com uma proporção média de $15,4 \pm 7,2 \%$ da população de cones, e chegando a compor cerca de $27 \%$ da população de cones em retina de D. bucephala. Em serpentes diurnas, a população de cones UV teve uma média de $5,7 \pm 2,2 \%$ da população total de fotorreceptores em todas as retinas analisadas. A proporção de cones UV apresentou valores similares em outras serpentes diurnas descritas na literatura, com 5,5\% em T. sirtalis (Sillman et al., 1997), 5,5\% em Philodryas olfersii e 5\% em $P$. patagoniensis (Hauzman, et al., 2014). Esta diferença entre noturnas e diurnas pode ser consequência da presença de um terceiro tipo de cone em retina de serpentes diurnas, que contém o fotopigmento Rh1. Em serpentes noturnas, a população de cones é subdividida em cones L/M e cones UV, que contribuem para uma visão dicromata neste grupo. Em serpentes diurnas a possibilidade de visão tricromata, com o pigmento Rh1 atuando em cone $\mathrm{M}$, levou a uma redução da proporção de cones UV.

\section{Genética do pigmento SWS1}

A determinação dos resíduos responsáveis pelo deslocamento espectral do pigmento SWS1 de vertebrados parece controverso e com mecanismos mais complexos do que os das outras classes de opsinas. Entretanto, é consenso invariável que o sítio 86 tem influência sobre o deslocamento de pigmentos UV para VS, e a presença do aminoácido F86 determina a sensibilidade no ultravioleta, em diferentes espécies de vertebrados (Cowing et al., 2002; Fasick et al., 2002; Davies et al., 2009). No presente estudo, foi considerado, portanto, que o resíduo F86 é determinante para estabelecer a 
sensibilidade UV nas serpentes estudadas. Apenas a serpente diurna e arborícola apresentou a mutação Phe86Val, e a serpente aquática foi heterozigota neste sítio, com a presença dos aminoácidos Val e Phe.

No roedor Cavia porcellus, a presença do resíduo Val86 no pigmento VS parece ser responsável pelo deslocamento espectral nesta espécie (Parry et al., 2004). A mutação sítio-direcionada Val86Phe causou um deslocamento de $60 \mathrm{~nm}$ do VS para o UV. Entretanto, a mutação reversa Phe86Val, não foi suficiente para causar alteração na sensibilidade espectral do pigmento UV para o azul, e o resíduo apolar Val86, assim como os resíduos Met86 e Leu86, parece ser incapaz por si só de exercer um efeito direto sobre a base de Schiff. Uma interação com outros resíduos seria, portanto, necessária para alterar o pico de sensibilidade de UVS para VS, como por exemplo, a presença de um aminoácido polar S90 (Parry et al., 2004). No caso das serpentes $C$. bicarinatus e $H$. modestus, assim como nas demais espécies estudadas, o sítio 90 é ocupado pelo resíduo apolar Alanina, indicando que apenas a mutação V86 não poderia ser responsável pelo deslocamento espectral do pigmento SWS1. Testes funcionais, comportamentais ou fisiológicos, ou microespectrofotometria, são necessários para confirmar a sensibilidade no UV destas espécies, e a possibilidade de outro resíduo além do S90, somado ao V86, influenciar no deslocamento espectral deste pigmento.

A topologia do cladograma do gene SWS1 em serpentes foi a que melhor corroborou a filogenia de serpentes determinada em outros estudos (Zaher et al., 2009; Pyron et al., 2013), indicando que este pigmento sofreu menor pressão seletiva e evoluiu dentro de cada grupo de serpente juntamente com a evolução das espécie. 


\subsection{Topografia da retina e estimativa teórica do poder de resolução espacial.}

\section{Distribuição de neurônios na retina e ecologia visual de serpentes.}

$\mathrm{Na}$ retina das serpentes estudadas, dois principais tipos de distribuição de neurônios foram observados, uma area centralis anisotrópica, com aumento irregular de densidade de células em diferentes regiões da retina, ou uma faixa horizontal fracamente definida. Na maioria das espécies o arranjo celular de fotorreceptores foi semelhante ao da distribuição de células da CCG.

De acordo com a teoria terrestre proposta por Hughes (1977), uma espécie que habita áreas abertas, onde o campo visual é dominado pela linha do horizonte, deve preferencialmente ter uma distribuição de células do tipo faixa horizontal, favorecendo a visão panorâmica do ambiente, sem a necessidade de constante movimentação da cabeça ou dos olhos. Por outro lado, animais que vivem em áreas florestadas, onde o campo visual é obstruído por folhagens, devem apresentar arranjos do tipo area cantralis, que favorecem a resolução espacial desta área circular. De acordo com esta proposta, seria esperado encontrar nas retinas de serpentes uma relação entre os diferentes hábitats ocupados pelas espécies e os arranjos topográficos de neurônios, sendo que serpentes que habitam preferencialmente campos abertos tenderiam a apresentar uma faixa horizontal, enquanto area centralis seriam esperadas em retinas de serpentes que habitam áreas de mata fechada.

Apenas três estudos descrevem a densidade e topografia de neurônios em retinas de serpentes. Nas serpentes marinhas L. curtus, D. major e A. laevis, Hart et al. (2012) verificaram a presença de faixa horizontal com três áreas de maior densidade de células da CCG. Em duas destas espécies, L. curtus e D. major, foi observada também uma evidente area centralis na região ventral das retinas. Em serpentes terrestres dois diferentes padrões de distribuição foram observados. Na terrícola Thamnophis sirtalis (Wong, 1989) e na arborícola Philodryas olfersii (Hauzman et al., 2014), foi observada 
uma faixa horizontal com uma area centralis na região central da retina. Na espécie terrícola P. patagoniensis (Hauzman et al., 2014), uma area cetralis anisotrópica foi observada na região ventral da retina, tanto nos mapas de fotorreceptores quanto de células da CCG. Desta forma, os padrões de distribuição de neurônios em retinas de serpentes não parecem corroborar a proposta da teoria terrestre. Alguns estudos mostraram a presença de uma faixa horizontal em espécies em que o horizonte não representa uma característica relevante do seu hábitat, ou a ausência desta distribuição em espécies que habitam campos aberto (Freeman \& Tancred, 1978; Silveira 1985; Silveira et al., 1989; Schiviz et al., 2008). Stone (1983) sugeriu que a topografia da retina deve ser um traço filogenético herdado e não necessariamente representa uma condição adaptativa de um estilo de vida de uma dada espécie atual. Se esta proposta fosse aplicada para serpentes, seria esperado um mesmo padrão de distribuição de células nas retinas das serpentes filogeneticamente próximas como $P$. olfersii e $P$. patagoniensis (Hauzman et al., 2014).

A partir dos resultados obtidos em retinas de Philodryas, foi sugerido que o micro-habitat deve representar um papel mais importante na ecologia visual de serpentes do que o hábitat (Hauzman et al., 2014). A espécie terrícola P. patagoniensis, por exemplo, apesar de ocupar áreas de campos abertos, tem o seu campo visual obstruído por folhagens. Uma area centralis na região ventral favorece a resolução espacial do campo de visão superior, que possibilita visualizar a aproximação de predadores aéreos, um importante mecanismo de defesa para animais rastejantes (Hauzman et al., 2014), como sugerido também para serpentes marinhas com area centralis na região ventral (Hart et al., 2012). Por outro lado, a estria horizontal em espécies arborícolas favorece a acuidade visual ao longo do eixo nasal-temporal, 
adaptações importantes para a locomoção e forrageamento no estrato arbóreo (Hauzman et al., 2014).

Este abrangente estudo comparativo da distribuição de neurônios de retinas de serpentes, revelou alguns padrões topográficos. As análises indicam que adaptações específicas relacionadas ao ritmo circadiano, hábitos e estratégia de caça de cada espécie, devem influenciar a distribuição de células mais do que as características do micro-habitat ocupado, o que revela a complexidade das estratégias adaptativas do sistema visual de serpentes. De maneira geral, espécies diurnas apresentaram a formação de uma faixa horizontal, na maioria das vezes pouco definida e com pico de densidade de células na região central, enquanto as espécies noturnas apresentaram a formação de area centralis anisotrópica, em diferentes regiões das retinas, dependendo da espécie.

Serpentes diurnas de hábitos arborícolas (S. pullatus e C. bicarinatus), terrícolas (E. undulata, E. aesculapii, E. poecilogyrus e T. dorsatus) ou semi-aquáticas (E. miliaris), apresentaram o mesmo tipo de distribuição de células da CCG e fotorreceptores, com a formação de faixa horizontal e maior densidade na região central da retina, favorecendo assim o campo de visão lateral monocular, acentuado ainda pelo posicionamento lateral do olho de serpentes. A presença de faixa horizontal pode ser associada a uma ampla percepção panorâmica do campo visual, sem a necessidade de movimentações da cabeça (Collin, 2008), o que acusaria a localização da serpente para possíveis presas, ou para predadores visualmente orientados.

Conforme esperado, a distribuição de cones L/M nas retinas de serpentes diurnas acompanhou a topografia dos fotorreceptores, dado que este grupo de células representa a maior parte da população de fotorreceptores, e tem papel fundamental na maximização da captura de fótons do ambiente (Osorio \& Vorobyev, 2005). A 
distribuição de cones UV, por sua vez, seguiu um padrão diferenciado dos outros tipos celulares, com a formação de area centralis na região ventral ou central da retina, ou ainda nasal em $C$. bicarinatus. As diferenças de localização da area centralis de cones UV não parece seguir um padrão relacionado ao uso de hábitat, nem tampouco à filogenia das espécies, sendo que outros fatores devem influenciar no deslocamento desta area nas retinas das diferentes espécies. Tipicamente, a proporção de cones sensíveis a comprimento de onda curto deve ser maior na região da retina que projeta para o céu (Szel et al., 2000; Briscoe et al., 2003). Este arranjo parece lógico, e deve maximizar o contraste de silhuetas de objetos (Osorio \& Vorobyev, 2005). Em serpentes Philodryas a area centralis de cones UV também foi observada na região ventral da retina (Hauzman et al., 2014).

Dentre as serpentes diurnas apenas a espécie de hábitos aquáticos, H. modestus, apresentou um tipo de distribuição de células distinto, sem a formação de faixa horizontal. O mapa topográfico de fotorreceptores mostrou uma area centralis na região ventro-temporal da retina, favorecendo a percepção do campo visual superior e frontal. Espécies de serpentes adaptadas ao ambiente aquático, sejam marinhos ou de água doce, geralmente possuem os olhos e as narinas posicionadas na região dorso-anterior da cabeça, bem como válvulas nasais que impedem a entrada de água quando submersas (Cadle \& Greene, 1993; Greene, 1997; Scartozzoni, 2005). Serpentes do gênero Helicops tem o hábito de permanecer com o corpo submerso, mantendo apenas narinas e olhos para fora da coluna d'água. $\mathrm{O}$ aumento de densidade de fotorreceptores na região ventral da retina permite então a melhor visualização do meio aéreo e da aproximação de predadores vindos de cima, e uma rápida resposta de fuga para dentro da água. Uma maior densidade de cones na região ventral da retina também foi 
observada na tartaruga de água doce Trachemys scripta elegans, que também apresenta o comportamento de manter o corpo submerso, com os olhos acima da linha da superfície da água, favorecendo a visualização da aproximação de predadores terrestres e semi-aquáticos, como a lontra e jacaré (Grotzner, 2005).

As células da CCG na retina de $H$. modestus apresentaram distribuição semelhante à dos fotorreceptores, com area centralis na metade ventral da retina, porém um pouco mais deslocada para o centro. A distribuição de cones L/M, por sua vez, mostrou uma topografia bastante divergente daquela observada para fotorreceptores. Uma faixa vertical na região nasal da retina, acompanhada por um aumento de densidade na região dorsal, possibilita uma maior sensibilidade no campo de visão posterior vertical e inferior. Considerando que a água doce é mais transparente à luz vermelha, com comprimento de onda longo (Lythgoe, 1984), a distribuição de cones L/M nas regiões nasal e dorsal da retina teria a vantagem de aumentar a captação de fótons na água e a percepção de movimento para detecção de peixes (Grotzner, 2005). A menor densidade de cones L/M foi observada no quadrante ventro-temporal da retina, exatamente na região de maior densidade de fotorreceptores, indicando que a concentração de cones UV juntamente com a do terceiro grupo de cones, contendo o fotopigmento de rodopsina Rh1, são determinantes para a topografia de fotorreceptores, e sua projeção para a região superior possibilita a melhor visualização do meio aéreo.

Nas serpentes de hábitos noturnos a distribuição de células apresentou a formação de area centralis anisotrópica, ou seja, com aumento irregular da densidade de células, o que reflete a complexidade de seu campo visual (Collin, 2008). As areae centrales foram observadas em diferentes regiões da retina, indicando variações 
adaptativas das espécies. Em alguns casos foi observada uma distribuição difusa, sem formação de especialização.

$\mathrm{Na}$ serpente fossorial Atractus reticulatus foi observada uma area na região dorsal da retina. Serpentes de hábitos fossoriais geralmente apresentam modificações relacionadas a necessidade de redução de atrito e que permitem a escavação de túneis em solo compacto (Greene, 1997). Essas espécies tendem a apresentar cabeças menores e compactas, quase indistintas do resto do corpo, fusão e/ou redução do número de escamas da cabeça, olhos pequenos e caudas curtas (Marx \& Rabb, 1972; Savitzky, 1983; Scartozzoni, 2005). As especializações da retina observadas nesta espécie, com a formação de area centralis tanto dos diferentes tipos de fotorreceptores, quanto de células da CCG, aumentam o poder de resolução espacial do campo de visão inferior e frontal do animal, favorecendo assim o hábito de escavar e a busca pelo seu alimento, anelídeos (Marques et al., 2001).

Em retinas da serpente arborícola Dipsas bucephala a area centralis anisotrópica de fotorreceptores e de células da CCG, se mostrou relativamente dispersa e extensa, com pico de densidade na região ventral das retinas, favorecendo o campo de visão superior. A distribuição de fotorreceptores foi dominada pela topografia dos bastonetes e apresentou alta densidade também na região central mas se estendendo até a região dorso-temporal. Tal distribuição relativamente dispersa dos bastonetes aponta para a necessidade de máxima captação de fótons de um ambiente de baixa luminosidade. A distribuição de cones, por sua vez, teve a formação de área mais delimitada e restrita à região ventral da retina (como a de células da CCG), o que aponta para uma maior importância do campo de visão superior nesta espécie para a visão em períodos de maior luminosidade. Serpentes noturnas repousam em abrigos durante o dia, para evitar o encontro com predadores visualmente orientados (Martins, 1994). 
Desta forma, a maior densidade de cones na região ventral da retina pode auxiliar na percepção de predadores aéreos durante o dia, como sugerido para a serpente diurna $P$. patagoniensis (Hauzman et al., 2014) e serpentes marinhas com area centralis ventral (Hart et al., 2012).

Em S. mikanii, serpente malacófaga, noturna e terrícola, a maior densidade de células na região temporal, levemente voltada para a metade ventral da retina, indica uma maior capacidade de resolução espacial do campo de visão anterior, que facilitaria seu forrageamento e a percepção de presas a sua frente. Em O. guibei, a área de fotorreceptores na região central da retina favorece a visão lateral monocular, assim como em S. neuwiedii. A distribuição de células da CCG de O. guibei se mostrou relativamente difusa, porém com a formação de uma faixa horizontal bastante discreta se estendendo ao longo de eixo nasal-temporal, e uma faixa vertical na região temporal da retina. Estas especializações podem favorecer o campo de visão panorâmico de Oxyrhopus e uma visão vertical do campo frontal. Cones e bastonetes não foram quantificados separadamente em retinas desta espécie e no mapa topográfico de fotorreceptores deve prevalecer a distribuição de bastonetes, em maior quantidade. Neste caso, é necessária a verificação da distribuição de cones para comparar com a topografia da CCG e comprovar a importância das especializações observadas. Entretanto, a topografia de cones $\mathrm{L} / \mathrm{M}$ se mostrou difusa, porém com uma tendência a acompanhar a distribuição de células da CCG, indicando que a distribuição do total de cones nesta espécie deve ser similar à de células da CCG, com uma possível formação de faixa horizontal.

Em Atractus, Dipsas e Sibynomorphus mikanii, a distribuição de cones L/M foi semelhante à distribuição de cones. A distribuição de cones UV em retinas de serpentes noturnas apresentou a formação de area centralis em todas as espécies estudadas, 
localizadas na região central (Atractus), ventral (Dipsas e $S$. mikanii) ou nasal (O.

guibei), sem uma aparente padronização relacionada ao uso de hábitat ou filogenia,

como observado em espécies diurnas.

Tabela 12. Espécies de serpentes utilizadas nos estudos comparativos da distribuição de neurônios da retina e tipos de especialização predominante.

\begin{tabular}{ccccc}
\hline Espécie & Atividade & Substrato & Dieta & Distribuição \\
\hline Atractus reticulatus & $\mathrm{N}$ & $\mathrm{FS}$ & $\mathrm{Al}$ & $\mathrm{AC}-$ dorso-temporal \\
Dipsas bucephala & $\mathrm{N}$ & $\mathrm{AR}$ & $\mathrm{Mo}$ & $\mathrm{AC}-$ ventral \\
Oxyrhopus guibei & $\mathrm{N}$ & $\mathrm{TE}$ & $\mathrm{Ma} ; \mathrm{La}$ & $\mathrm{AC}-$ central \\
Sibynomorphus mikanii & $\mathrm{N}$ & $\mathrm{TE}$ & $\mathrm{Mo}$ & $\mathrm{AC}-$ temporal \\
Sibynomorphus neuwiedii & $\mathrm{N}$ & $\mathrm{AR} / \mathrm{TE}$ & $\mathrm{Mo}$ & $\mathrm{AC}-$ central \\
\hline Chironius bicarinatus & $\mathrm{D}$ & $\mathrm{S}-\mathrm{AR}$ & $\mathrm{An}$ & $\mathrm{FH}-$ central \\
Echinantera undulata & $\mathrm{D}$ & $\mathrm{TE}$ & $\mathrm{An}$ & $\mathrm{FH}-$ central \\
Erythrolamprus aesculapii & $\mathrm{C}$ & $\mathrm{TE}$ & $\mathrm{Se}$ & $\mathrm{FH}-$ central \\
Erythrolamprus miliaris & $\mathrm{D} / \mathrm{N}$ & $\mathrm{S}-\mathrm{AQ}$ & $\mathrm{Gn}$ & $\mathrm{FH}-$ central \\
Erythrolamprus poecilogyrus & $\mathrm{D} / \mathrm{N}$ & $\mathrm{TE}$ & $\mathrm{La} ; \mathrm{An}$ & $\mathrm{FH}-$ central \\
Helicops modestus & $\mathrm{D} / \mathrm{N}$ & $\mathrm{AQ}$ & $\mathrm{Pe} ; \mathrm{An}$ & $\mathrm{AC}-$ ventral \\
Spilotes pullatus & $\mathrm{D}$ & $\mathrm{AR}$ & $\mathrm{Ma} ; \mathrm{Av}$ & $\mathrm{FH}-$ central \\
Thamnodynastes strigatus & $\mathrm{C} / \mathrm{N}$ & $\mathrm{S}-\mathrm{AR} / \mathrm{TE}$ & $\mathrm{An} ; \mathrm{La}$ & $\mathrm{FH}-$ central \\
Tomodon dorsatus & $\mathrm{D}$ & $\mathrm{TE}$ & $\mathrm{Mo}$ & $\mathrm{FH}-$ central \\
\hline
\end{tabular}

C, crepuscular; D, diurna; N, noturna; AQ, aquático; AR, arborícola; CR, criptozóico; FS, fossorial; S-AQ, semi-aquático; S-AR, semi-arborícola; TE, terrícola; Al, anelídeos; Mo, moluscos; Ma, mamíferos; Na, anfíbios anuros; Se, serpentes; Pe, peixes; Av, aves; AC - area centralis, $\mathrm{FH}$ - faixa horizontal,

Em suma, a variação dos tipos de especialização entre serpentes diurnas e noturnas (Tabela 12) pode ter relação com fatores como estratégias de caça e percepção de potenciais predadores no ambiente. A presença de faixa horizontal que possibilita o rastreamento do ambiente, sem a necessidade de constante movimentação da cabeça pode ser vital para serpentes que forrageiam ativamente durante o dia. Serpentes ativas durante a noite, por sua vez, passam a maior parte do dia em repouso, camufladas. Durante a noite, o número de predadores visualmente orientados deve reduzir consideravelmente, e a necessidade de movimentação dos olhos e cabeça para percepção do ambiente à sua volta não deve ser um comportamento que precisa ser evitado. 


\section{Densidade de células da CCG e o poder de resolução espacial.}

Os valores de densidade média e da população total de células da CCG foram significativamente menores em serpentes de hábitos noturnos, comparado com as diurnas. A média da população de células em retinas de serpentes noturnas foi de 73.134 \pm 43.567 células, com menor valor obtido para Atractus pantostictus (20.860 células), e o maior valor em retina de Dipsas petersi (175.154 células). Nas serpentes diurnas, a média da população de células da CCG foi de $249.828 \pm 157.498$, células, com menor valor em retina da serpente aquática $H$. modestus (82.172 células), e maior valor em retina da serpente arborícola $S$. pulatus (627.447 células). Dados da literatura revelam valores de densidade de células da CCG para serpentes terrestres e diurnas semelhantes aos valores obtidos para as serpentes diurnas analisadas neste trabalho. A média da densidade da população de células em $P$. olfersii foi de $307.605 \pm 80.422$ e em $P$. patagoniensis de $350.294 \pm 64.756$ células (Hauzman et al., 2014), valores levemente maiores do que o estimado por Wong (1989) em retina de T. sirtalis, com $209.800 \pm$ 1.150 células. Os valores estimados para serpentes marinhas também de hábitos diurnos, foram menores do que os encontrados para serpentes terrestres, e se assemelham aos valores obtidos para serpentes de hábitos noturnos e para a aquática $H$. modestus: 104.011 células em Aipysurus laevis; 31.977 células em Disteira major; e 72.597 células em Lapemis curtus (Hart et al., 2012).

O poder de resolução espacial, estimado com base no pico de densidade de células da CCG e na distância focal também foi significativamente maior em serpentes de hábitos diurnos, o que aponta para a importância de uma melhor qualidade de imagem em serpentes de hábitos diurnos que forrageiam ativamente em fotoperíodos de maior iluminação. A média do poder de resolução espacial de serpentes diurnas foi de 2,3 $\pm 0,7 \mathrm{cpg}$, semelhante aos valores descritos na literatura para outras espécies diurnas 
terrestres: P. olfersii e P. patagoniensis com 2,6 e 2,7 cpg, respectivamente (Hauzman et al., 2014), e T. sirtalis, com 2,3 cpg (Hart et al., 2012), valor este estimado a partir do pico de densidade de células ganglionares de 10.000 celulas $/ \mathrm{mm}^{2}$ (Wong, 1989) e PND de 2,5 mm (Land \& Snyder, 1985). A média da acuidade das serpentes noturnas foi de 1,45 $\pm 0,4$ cpg. Dada a elevada densidade de bastonetes em retinas de serpentes noturnas, uma redução da acuidade visual seria esperada, uma vez que este tipo de fotorreceptor, altamente especializado na captura de fótons sob baixa luminosidade, possui capacidade de integração temporal maior do que de cones, o que compromete o seu poder de resolução espacial (Ali \& Klyne, 1985). A alta convergência de fotorreceptores para células ganglionares contribui para o aumento da sensibilidade, porém acarreta redução do poder de resoluçao espacial.

O poder de resolução espacial em serpentes de hábitos aquáticos também foi menor do que o de serpentes diurnas terrestres, e se assemelharam aos valores médios de acuidade visual de serpentes noturnas. Nas espécies marinhas a resolução máxima foi de 1,13 cpg em D. major, 1,56 cpg em L. curtus e 2,25 cpg em A. laevis. Em $H$. modestus a acuidade visual média foi de 1,4 $\pm 0,1 \mathrm{cpg}$. Dado que estas espécies diurnas apresentam retinas com apenas cones e uma convergência relativamente baixa de fotorreceptores para células ganglionares (1,5:1 em $H$. modestus), pode-se supor que o valor reduzido de acuidade visual é consequente da redução do diâmetro axial do olho e da distância focal. Essas diferenças observadas com relação às espécies diurnas devem decorrer da variação das propriedades físicas do meio aquático, como a maior refração da luz. Mesmo nas mais claras águas de hábitats subaquáticos, a luz é dispersa, o que resulta em uma redução na qualidade da imagem com a distância, em relação à visão no meio aéreo. Neste caso, a redução do poder de resolução espacial pode estar associada 
ao desenvolvimento de outros órgão sensoriais, como por exemplo, a capacidade de percepção de vibrações na água, para captura de peixes.

\section{A validade do método de estimativa do poder de resolução espacial com base na densidade de células da CCG.}

A observação do tecido marcado com Nissl pode levar a uma super estimação da densidade de células ganglionares, uma vez que células amácrinas deslocadas também são coradas, alterando desta forma o valor estimado do poder teórico de resolução espacial (Wong \& Hughes, 1987; Collin \& Pettigrew, 1988; Pettigrew et al., 1988; Bailes et al., 2006). Alguns autores, para distinguir as células ganglionares das amácrinas deslocadas utilizam a técnica de marcação retrógrada, a partir do nervo óptico. Estudos comparando os resultados das duas técnicas mostraram que apesar da proporção de amácrinas na camada de células ganglionares variar consideravelmente

entre os vertebrados, na grande maioria das espécies os picos de densidade e a distribuição topográfica total de células permanece relativamente igual, apesar da inclusão da população de amácrinas deslocadas (Coimbra et al., 2006; Collin, 1988; 1999; Collin \& Pettigrew, 1988; Collin \& Northcutt, 1993; Hart, 2002; Lisney \& Collin, 2008; Pettigrew et al., 1988). A marcação retrógrada não marca com sucesso todas as células ganglionares, então o pico de densidade deve estar entre os valores estimados usando a coloração de Nissl e a marcação retrógrada (Bailes et al., 2006).

Por outro lado, a inclusão de células amácrinas não tem influência significativa na estimativa da acuidade visual. O poder de resolução espacial é expresso como uma medida linear relacionado, portanto, à raiz quadrada da densidade celular, e assim a super estimação de células ganglionares em $30 \%$ contribuiria com apenas cerca de $6 \%$ para a estimativa final do poder de resolução espacial, valor este muito baixo, 
considerando que a variação entre os indivíduos pode ser maior que $40 \%$ (Pettigrew et al., 1988; Collin \& Pettigrew, 1989).

Medidas comportamentais do poder de resolução espacial se aproximam daquelas calculadas a partir da densidade de células ganglionares de vertebrados (Hughes, 1977; Pettigrew et al., 1988; Collin \& Pettigrew, 1989), o que sugere a validade desta técnica (Collin \& Pettigrew, 1989; Wagner et al., 1998). Na Tabela 13 o poder de resolução espacial estimado a partir da densidade de células da CCG é comparado com os resultados de acuidade obtidos a partir de estudos comportamentais, em algumas espécies de diferentes grupos de vertebrados.

Tabela 13. Estimativas de acuidade visual obtidas a partir de dados morfológicos, e para algumas espécies, comparação com os valores obtidos a partir de registros comportamentais (tabela adaptada de Pettigrew \& Manger, 2008).

\begin{tabular}{|c|c|c|c|c|}
\hline Espécie & $\begin{array}{l}\text { Acuidade visual: } \\
\text { densidade de } \\
\text { células da CCG } \\
\text { (cpg) }\end{array}$ & Referência & $\begin{array}{l}\text { Acuidade visual: } \\
\text { medidas } \\
\text { comportamentais } \\
(\mathrm{cpg})\end{array}$ & Referência \\
\hline Águia & 147 & Reymond, 1985 & 140 & Reymond, 1985 \\
\hline Homem & 65 & Curcio \& Allen, 1990 & 60 & Campbell \& Gubisch, 1967 \\
\hline Cavalo & 25 & Evans \& McGreevy, 2007 & 20 & Timney \& Keil, 1992 \\
\hline Pavão & 20,6 & Hart, 2002 & - & - \\
\hline Galinha & - & - & 7 & Donner, 1951 \\
\hline Pombo & 18 & Remy \& Gunturkun, 1991 & 12 & Hodos et al., 1976 \\
\hline Gato & 10 & Cleland et al., 1982 & 9 & Hall \& Mitchell, 1991 \\
\hline Hiena & 8,4 & Calderone et al., 2003 & - & - \\
\hline Cutia & 7 & Silveira et al., 1989 & - & - \\
\hline Golfinho & 6 & Mass \& Supin, 1995 & 3 & Pepper \& Simmons, 1973 \\
\hline Rinoceronte & 6 & Pettigrew \& Manger, 2008 & - & - \\
\hline Coelho & 6 & Vaney \& Hughes, 1976 & - & - \\
\hline Capivara & 6 & Silveira et al., 1989 & - & - \\
\hline Polvo & - & - & 4 & Muntz \& Gwyther, 1989 \\
\hline Paca & 3 & Silveira et al., 1989 & - & - \\
\hline Rato & 1 & Dean, 1981 & 1 & Prusky et al., 2000 \\
\hline Camundongo & 0,6 & Gianfranceschi et al., 1999 & $\begin{array}{l}0,6 \\
0,5\end{array}$ & $\begin{array}{l}\text { Gianfranceschi et al., 1999; } \\
\text { Prusky et al., } 2000\end{array}$ \\
\hline Serpente Nerodia & - & - & $4,25 *$ & Baker et al., 2007 \\
\hline $\begin{array}{l}\text { Serpente Philodryas } \\
\text { Serpentes marinhas: }\end{array}$ & 2,6 & Hauzman et al., 2014 & - & - \\
\hline $\begin{array}{l}\text { - Disteira major } \\
\text { - Lapemis curtus } \\
\text { - Aipysurus laevis }\end{array}$ & $\begin{array}{l}1,1 \\
1,6 \\
2,3\end{array}$ & Hart et al., 2011 & - & - \\
\hline
\end{tabular}




\section{CONCLUSÕES}

- Neste estudo comparativo foram amplificados e sequenciados os genes de três classes de pigmentos visuais expressos em retinas de serpentes diurnas e noturnas das famílias Colubridae e Dipsadidae: o gene Rh1 (de bastonetes), o SWS1 (de opsinas sensíveis a comprimentos de onda curtos) e o LWS (de opsinas sensíveis a comprimentos de onda longos). As análises filogenéticas mostraram que os genes sequenciados são ortólogos aos genes dos pigmentos visuais dos demais vertebrados.

- Os picos de sensibilidade espectral dos fotopigmentos Rh1, SWS1 e LWS de serpentes Caenophidia foram estimados a partir das sequências de aminoácidos presentes nos sítios específicos envolvidos no deslocamento espectral.

$\checkmark$ O pigmento Rh1 de serpentes noturnas apresentou $\lambda_{\max }$ de 494 ou 500 nm; em todas as espécies diurnas as mutações D83N e A292S podem gerar um deslocamento para o azul de $16 \mathrm{~nm}$ e um $\lambda_{\max }$ de $484 \mathrm{~nm}$. O gene Rh1 expresso em cones nas retinas de serpentes diurnas deve contribuir para o aumento da capacidade de resolução espacial e/ou da discriminação de diferentes comprimentos de onda, e a possibilidade de visão de cores tricromata nestas espécies.

$\checkmark \mathrm{O}$ aminoácido F89 do pigmento SWS1 indica a sensibilidade à luz ultravioleta, e foi observado em todas as espécies sequenciadas, com exceção de Chironius bicarinatus, que apresentou V89, e Helicops modestus que foi heterozigota, com os dois aminoácidos V e F, neste sítio. A mutação F89V por si só não é suficiente para alterar o comprimento de onda do pigmento SWS1 do UV para o VS e, portanto, foi considerado que todas as espécies são sensíveis na faixa do UV, em $360 \mathrm{~nm}$. 
De acordo com a regra dos "cinco sítios" o pigmento LWS apresentou 4 diferentes combinações de aminoácidos nas espécies estudadas, gerando os picos de sensibilidade $\lambda_{\max }$ de $560,553,543$ e $537 \mathrm{~nm}$. Em serpentes noturnas da Subfamília Dipsadinae (Atractus, Dipsas e Sibynomorphus) o maior deslocamento para o azul $\left(\lambda_{\max } 537 \mathrm{~nm}\right)$ pode estar associado a uma compensação do sinal de ruído noturno ocasionado pela isomerização térmica, que ocorre com maior frequência em pigmentos com picos de sensibilidade em comprimentos de onda mais longos.

- Serpentes diurnas e noturnas diferiram quanto aos tipos de fotorreceptores presentes na retina. Espécies noturnas apresentaram grande quantidade de bastonetes e dois grupos de cones: cones grandes marcados pelo anticorpo antiopsinas $\mathrm{L} / \mathrm{M}$, e cones pequenos marcados pelo anticorpo anti-opsinas $\mathrm{S}$. Serpentes diurnas apresentaram baixa densidade de fotorreceptores e ausência de bastonetes. Três tipos morfológicos de cones puderam ser distinguidos: cones grandes e cones duplos, marcados pelo anticorpo anti-opsinas L/M, e cones simples pequenos marcados pelo anticorpo anti-opsinas S. Um quarto grupo de cones simples pequenos não foi marcado por nenhum anticorpo e pode contar o pigmento Rh1 de rodopsina.

- A densidade média de fotorreceptores foi significativamente maior nas retinas de serpentes noturnas; a densidade média de células da CCG foi maior nas retinas de serpentes de hábitos diurnos, assim como os valores estimados do poder de resolução espacial. Estas variações apontam para a importante adaptação do sistema visual ao ritmo circadiano das espécies; serpentes diurnas têm retinas com baixa sensibilidade à luz, porém com maior resolução espacial, enquanto 
espécies noturnas têm alta sensibilidade, porém baixa resolução espacial, devido à alta convergência de fotorreceptores para células ganglionares.

- A densidade de cones L/M foi semelhante nos dois grupos de serpentes, porém a densidade de cones UV foi mais alta em serpentes noturnas. Variações de densidade de cones UV podem estar relacionadas com tipos de presa e estratégias reprodutivas nas diferentes espécies.

- A distribuição de neurônios nas retinas parece estar relacionada às variações do padrão de atividade de serpentes. De maneira geral, serpentes diurnas apresentaram faixa horizontal, enquanto espécies noturnas apresentaram area centralis em diferentes regiões da retina, dependendo da espécie. Estas variações podem refletir as estratégias de forrageamento das diferentes espécies; a presença de uma faixa horizontal possibilita melhor visualização do ambiente, sem a necessidade de movimentação da cabeça, comportamento este que acusaria a posição do animal para as presas, ou para predadores visualmente orientados. Serpentes ativas durante período noturno permanecem a maior parte do dia em repouso em abrigos, e não devem ter a necessidade de monitorar o ambiente a sua volta de maneira ampla. Uma area centralis que proporciona maior capacidade de resolução espacial de uma área mais restrita da retina pode ser mais vantajosa para as atividades em períodos de baixa iluminação.

- Os resultados obtidos neste abrangente estudo apontam para a complexidade das adaptações do sistema visual de serpentes. As variações do padrão de atividade (diurna ou noturna) e uso de hábitat parecem ser fatores de forte influência sobre as características do sistema visual, como a sensibilidade espectral dos pigmentos visuais, a densidade e distribuição de neurônios nas retinas e o poder de resolução espacial do olho. 


\section{REFER ÊNCIAS BIBLIOGRÁFICAS}

Alberts, A. C. (1989). Ultraviolet visual sensitivity in desert iguanas: implications for pheromone detection. Animal Behaviour, 38, 129-137.

Ali, M. A. \& Anctil, M. (1976). Retinas of fishes: an atlas. New York, NY: Springer.

Ali, M.A. \& Klyne, M.A. (1985). Vision in Vertebrates. Plenum Press, New York and London, $272 \mathrm{p}$.

Andrade-Da-Costa, B. L. S, Pessoa, V. F., Bousfield, J. D. \& Clarke, R. J. (1989). Ganglion cell size and distribution in the retina of the two-toed sloth (Choloepus didactylus L.). Braz J Med Biol Res, 22, 233-236.

Bailes, H. J., Trezise, A. A. O. \& Collin, S. P. (2006). The number, morphology, and distribution of retinal ganglion cells and optic axons in the Australian lungfish Neoceratodus forsteri (Krefft 1870). Visual Neuroscience, 23, 257-273.

Bailes, H. J., Davies, W. L., Trezise, A. E. O. \& Collin, S. P. (2007). Visual pigments in a living fossil, the Australian lungfish Neoceratodus forsteri. BMC Evolutionary Biology, 7, 200.

Baker, R. A.; Gawne, T. J.; Loop, M. S. \& Pullman, S. (2007). Visual acuity of the midland banded water snake estimated from evoked telencephalic potentials. Journal of Comp Physiology A: Neuroethology, Sensory, Neural, and Behavioral Physiology, 193, 865-870.

Barlow, H. B. (1957). Purkinje shift and retinal noise. Nature, 179, 255-256.

Bennett, A. T. D., Cuthill, I. C. \& Partridge, J. C. (1996). Ultraviolet vision and mate choice in zebra finches. Nature, 380, 433-435.

Bennett, A. T. D., Cuthill, I. C. \& Partridge, J. C. (1997). Ultraviolet plumage colors predict mate preferences in starlings. Proc. Natl. Acad. Sci. USA, 94, 86188621.

Bellini, G. P., Arzamendia, V. \& Giraudo, A. R. (2013). Ecology of Thamnodynastes hypoconia in Subtropical-Temperate South America. Herpetologica, 69, 67-79.

Bernarde, P. S. \& Abe, A. S. (2006). A snake community at Espigão do Oeste, Rondônia, Southwestern Amazon, Brazil. South Am Journal of Herpetology, 1, 102-113.

Bernarde, P. S., Kokubum, M. N. C. \& Marques, O. A. V. (2000). Utilização de hábitat e atividade em Thamnodynastes strigatus (Gunther, 1858) no sul do Brasil (Serpentes, Colubridae). Museu Nacional, 428, 1-8.

Boire, D., Dufour, J. S., Theoret, H. \& Ptito, M. (2001). Quantitative analysis of the retinal ganglion cell layer in the ostrich, Struthio camelus. Brain Behav Evol, 58, 343-355.

Boehlert, G. W. (1978). Intraspecific evidence for function of single and double cones in teleost retina. Science, 202, 309-311.

Bowmaker, J. K. (1991). The evolution of Vertebrate Visual Pigments and Photoreceptors. In. Cronly-Dillon, J. \& Gregory, R.L. (eds). Vision and Visual Dysfunction Vol 2: Evolution of the Eye and Visual System. Macmilla Press.

Bowmaker, J. K. (2008). Evolution of vertebrate visual pigments. Vision Research, 48, 2022-2041.

Bowmaker, J. K. \& Hunt, D. M. (2006). Evolution of vertebrate visual pigments. Current Biology, 16, n. 13.

Briscoe, A. D., Bernard, G. D., Szeto, A. S., Nagy, L. M. \& White, R. H. (2003). Not all butterfly eyes are created equal: rhodopsin absorption spectra, molecular 
identification, and localization of ultraviolet-, blue-, and green-sensitive rhodopsin-encoding mRNAs in the retina of Vanessa cardui. J. Comp. Neurol. 458, 334-349.

Brown, K. T. (1969). A linear area centralis extending across the turtle retina and stabilized to the horizontal by non visual cues. Vision Res, 9 (9), 1053-1054.

Buck, S. L., Thomas, L. P. \& Hillyer, N. (2006). Do rods influence the hue of foveal stimuli? Visual Neurosc, 23, 519-523.

Burkhardt, D. (1982). Birds, berries and UV. Naturwissenschaften 69, 153-157.

Burns, M. E. \& Lamb, T. D (2003). Visual transduction by rod and cone photoreceptors. Center for Neuroscience and Department of Psychiatry, University of California, Davis, CA, and Physiological Laboratory, University of Cambridge, Cambridge, CB2 3EG, UK.

Cadle, J. E. (1987). Geographic distribution: problems in phylogeny and zoogeography. In: Seigel, R.A., Collins, J.T. \& Novak, S.S. Snakes: Ecology and Evolutionary Biology. McGraw-Hill Publishing Company, New York, p. 77-105.

Cadle, J. E. \& Greene, H. W. (1993). Phylogenetic patterns, biogeography, and the ecological structure of Neotropical snake assemblages. In: Ricklefs, R.E.; Schluter, D. (eds.). Species diversity in ecological communities: historical and geographical perspectives. Chicago: University of Chicago Press. p. 281-293

Calderone, J. B. \& Jacobs, J. G. (1999). Cone receptor variations and their functional consequences in two species of hamster. Vis Neurosc, 16, 53-63.

Calderone, J. B., Reese, B. E. \& Jacobs, G. H. (2003). Topography of photoreceptors and retinal ganglion cells in the spotted hyena (Crocuta crocuta). Brain, Behavior and Evolution, 62, 182-192.

Cameron, D. A. \& Pugh, E. N. (1991). Double cones as a basis for a new type of polarization vision in vertebrates. Nature, 353, 161-164.

Campbell, F. W. \& Gubisch, R. W. (1967). The effect of chromatic aberration on visual acuity. Journal of Physiology, 192, 345-358.

Campenhausen, M. V. \& Kirschfeld, K. (1998). Spectral sensitivity of the accessory optic system of the pigeon. J. Comp. Physiol. A, 183, 1-6.

Caprette, C. L. (2005). Conquering the cold shudder: the origin and evolution of snakes eyes. Ph.D. Thesis, The Ohio State University.107p.

Caprette, C. L., Lee, M. S. Y., Shine, R., Mokany, A. \& Downhower, J. F. (2004). The origin of snakes (Serpentes) as seen through eye anatomy. Biological Journal of the Linnean Society, 81, 469-482.

Chiu, M. I., Zack, D. J., Wang, Y. \& Nathans, J. (1994) Murine and bovine blue cone pigment genes: cloning and characterization of two new members of the $S$ family of visual pigments. Genomics, 21, 440-443.

Cleland, B. G., Crewther, D. P., Crewther, S. G. \& Mitchell, D.E. (1982). Normality of spatial resolution of retinal ganglion cells in cats with strabismic amblyopia. Journal of Physiology, 326, 235-249.

Coates, M. \& Ruta, M. (2000). Nice snake, shame about the legs. Trends in Ecology \& Evolution 15, 503-507.

Coimbra, J. P., Marceliano, M. L. V., Andrade-da-Costa, B. L. S. \& Yamada, E. S. (2006). The retina of tyrant flycatchers: topographic organization of neuronal density and size in the ganglion cell layer of the great kiskadee Pitangus sulphuratus and the rusty margined flycatcher Myiozetetes cayanensis (Aves: Tyrannidae). Brain Behav Evol, 68, 15-25.

Coimbra, J. P., Trevia, N., Marceliano, M. L., da Silveira Andrade-Da-Costa, B. L., Picanço-Diniz, C. W. \& Yamada, E. S. (2009): Number and distribution of 
neurons in the retinal ganglion cell layer in relation to foraging behaviors of tyrant flycatchers. J Comp Neurol, 514, 66-73.

Coimbra, J. P., Nolan, P. M., Collin, S. P. \& Hart, N. (2012): Retinal ganglion cell topography and spatial resolving power in penguins. Brain Behav Evol, 80, 254268.

Coimbra, J. P., Hart, N., Collin, S. P. \& Manger, P. R. (2013): Scene from above: retinal ganglion cell topography and spatial resolving power in the giraffe (Giraffa camelopardalis). J Comp Neurology, 521, 2042-2057

Collin, S. P. (1988). The retina of the shovel-nosed ray, Rhinobatos batillum (Rhinobatidae): morphology and quantitative analysis of the ganglion, amacrine and bipolar cell populations. Exp Biol, 47, 195-207.

Collin, S. P. (1999). Behavioural ecology and retinal cell topography. In: Adaptive Mechanisms in the Ecology of Vision. Eds: Archer, S.N.; Djamgoz, M.B.A.; Loew, E.R.; Partridge, J.C.; Vallerga, S. Dordrecht: Kluwer Academic Publishers. pp. 509-535.

Collin, S. P. (2008). A web-based archive for topographic maps of retinal cell distribution in vertebrates. Clin Exp Optom, 91, 85-95.

Collin, S. P. \& Collin, H. B. (1999). The foveal photoreceptor mosaic in the pipefish, Corythoichthyes paxtoni (Syngnathidae, Teleostei). Histol Histopathol, 14, 369382.

Collin, S. P. \& Partridge, J. C. (1996). Retinal specialisations in the eyes of deep-sea teleosts. J Fish Biol (Suppl A), 49, 157-174.

Collin, S. P. \& Northcutt, R. G. (1993). The visual system of the Florida garfish, Lepisosteus platyrhinchus (Ginglymodi). III. Retinal ganglion cells. Brain Behav Evol, 42, 295-320.

Collin, S. P. \& Pettigrew, J. D. (1988). Retinal ganglion cell topography in teleosts: a comparison between Nissl-stained material and retrograde labelling from the optic nerve. J. Comp Neurol, 276, 412-422.

Collin, S. P. \& Pettigrew, J. D. (1989). Quantitative comparison of the limits on visual spatial resolution set by the ganglion cell layer in twelve species of reef teleosts. Brain Behav Evol, 34, 184-192.

Collin, S. P., Knight, M. A., Davies, W. L., Potter, I. C., Hunt, D. M. \& Trezise, A. E. (2003). Ancient colour vision: multiple opsin genes in the ancestral vertebrates. Curr. Biol., 13, R864-R865.

Cowing, J. A., Poopalasundaram, S., Wilkie, S. E., Robinson, P. R., Bowmaker, J. K. \& Hunt, D. M. (2002). The molecular mechanism for the spectral shifts between vertebrate ultraviolet- and violet-sensitive cone visual pigments. Biochem J, 367, $129-135$.

Curcio, C. A. \& Allen, K. A. (1990). Topography of ganglion cells in human retina. $J$ Comp Neurology, 300, 5-25.

Davies, W. L. (2011) Adaptive gene loss in vertebrates: photosensitivity as a model case. In: Encyclopedia of Life Sciences (ELS). John Wiley \& Sons Ltd, Chichester.

Davies, W. L., Cowing, J. A., Bowmaker, J. K., Carvalho, L. S., Gower, D. J. \& Hunt, D. M. (2009). Shedding light on serpent sight: the visual pigments of Henophidian snakes. The Journal of Neuroscience, 29(23), 7519 -7525.

Davies, W. I. L., Collin, S. P. \& Hunt, D. M. (2012). Molecular ecology and adaptation of visual photopigments in craniates. Molecular Ecology, 21, 3121-3158.

De Valois, R. L. (1965). Analysis and Coding of Color Vision in the Primate Visual System. Cold Spring Harb Symp Quant Biol, 30, 567-579. 
Dean, P. (1981). Visual pathways and acuity in hooded rats. Behav Brain Research, 3, 239-271.

Deeb, S. S. \& Motulsky, A. G (2005). Reed-Green colour vision defects. In R.A. Pagon, T.C. Bird, C.R. Dolan \& K. Stephens (Eds), GeneReviews [Internet]. Seattle (WA): University of Washington, Seattle.

Desjardins, C., Maruniak, J. A. \& Bronson, F. H. (1973). Social rank in house mice: differentiation revealed by ultraviolet visualization of urinary marking patterns. Science 182, 939-941.

Dixon, J. R. \& Markezich, A. L. (1992). Taxonomic and geographic variation of Liophis poecilogyrus (Weid) from South America (Serpentes: Colubridae). Texas J. Sci. 44(2), 131-166.

Dixon, J. R. \& Soini, P. (1977). The reptiles of the upper Amazon basin, Iquitos region, Peru. II. Crocodilians, turtles, and snakes. Milwaukee Public Museum. Contributions in Biology and Geology, 12, 1-71.

Donner, K. O. (1951). The visual acuity of some passerine birds. Acta Zool Fenn, 66, 140.

Dowling, J. E. (1987). The Retina: an approachable part the brain. Belknap Press of Harvard U. Press, Cambridge, Mass.

Ebrey, T. \& Koutalos, Y. (2001). Vertebrate photoreceptors. Prog. Ret. Eye Res., 20, 49-94.

Ebrey, T. G. \& Takahashi Y. (2002). Photobiology of retinal proteins. In Photobiology for the 21st Century, ed. TP Coohill, DP Valenzeno, pp. 101-33. Overland Park, KS: Valdenmar.

Ehrlich, D. (1981): Regional specialization of the chick retina as revealed by the size and density of neurons in the ganglion cell layer. J Comp Neurol 195, 643-657.

Evans, K. E. \& McGreevy, P. D. (2007). The distribution of ganglion cells in the equine retina and its relationship to skull morphology. Anatomia, Histologica, Embryologia, 36, 151-156.

Fasick, J. L. \& Robinson, P. R. (2000). Spectral-tuning mechanisms of marine mammal rhodopsins and correlations with foraging depth. Visual Neuroscience, 17, 781788.

Fasick, J. L., Lee, N., Oprian, D. D. (1999). Spectral tuning in the human blue cone pigment. Biochemistry, 38, 11593-11596.

Fasick, J. I., Applebury, M. L. \& Oprian, D. D. (2002) Spectral tuning in the mammalian short-wavelength sensitive cone pigments. Biochemistry, 41, 68606965.

Felsenstein, J. (1985). Confidence limits on phylogenies: an approach using the bootstrap. Evolution, 39, 783-791

Fernald, R. D. (1990). The optical system of fishes. In: Douglas RH, Djamgoz MB, eds. The Visual System of Fish. London: Chapman and Hall. 45-61

Ford, N. B. \& Burghardt, G. M. (1993). Perceptual mechanisms and the behavioral ecology of snakes. In: Seigel R.A., Collins J.T. (eds) Snakes: ecology and behavior. McGraw-Hill. San Francisco, pp 117-164.

Ford, N. B. \& Low, J. R..Jr (1984). Sex pheromone source location by garter snakes. A mechanism for detection of direction in non-volatile trails. J. Chem. Ecol. 10, 1193-1199.

Freeman, B. \& Tancred, E. (1978): Number and distribution of ganglion cells in the retina of the brush-tailed possum, Trichosurus vulpecula. J Comp Neurol, 177, $557-567$ 
Gehring, W. J. \& Ikeo, K. (1999). Pax 6 mastering eye morphogenesis and eye evolution. Trends Genet. 15, 371-377.

Gianfranceschi, L., Fiorentini, A. \& Maffei, L. (1999). Behavioural visual acuity of wild type and bcl2 transgenic mouse. Vision Research, 39, 569-574.

Gibbons, J. W. \& Semlitsch, R. D. (1987). Activity Patterns. In: Snakes: Ecology and Evolutionary Biology. SEIGEL, R. A.; COLLINS, J. T.; NOVAK, S. S. Eds, New York, McGraw-Hill Publishing Company. p. 396-421.

Goldsmith, T. H. \& Butler, B. K. (2003). The roles of receptor noise and cone oil droplets in the photopic spectral sensitivity of the budgerigar, Melopsittacus undulatus. J. Comp. Physiol. A, 189, 135-142

Govardovskii, V. I. \& Chkheidze, N. I. (1989). Retinal photoreceptors and visual pigments in certain snakes. Biol Abstr, 90, 1036.

Granda, A. M. \& Haden, K. W. (1970). Retinal oil globule counts and distribution in two species of turtles: Pseudemys scripta elegans and Chelonia mydas mydas. Vision Res, 1, 79-84.

Grazziotin, F. G., Zaher, H., Murphy, R. W., Scrocchi, G., Benavides, M. A., Zhang, Y. P. \& Bonatto, S. L. (2012). Molecular phylogeny of the New World Dipsadidae (Serpentes: Colubroidea): a reappraisal. Cladistics, 1, 1-23.

Greene, H. W. (1997). Snakes. The evolution of mystery in Nature. Berkeley, University of California Press. 351p.

Grötzner, S. R. (2005). Densidade e topografia dos fotorrecptores da retina da tartaruga Trachemys scripta elegans com imunocitoquímica de opsinas. Tese (Doutorado) Universidade de São Paulo, Instituto de Psicologia, Programa de Neurociência e Comportamento. $158 \mathrm{p}$

Grötzner, S. R., Rocha, F. A. F., Lima, S. M. A., Hamassaki-Britto, D. E., Vithelic, T. S., Hisatomi, O. \& Ventura, D. F. (2004). Topographic density of L, M and S cones in the turtle retina investigated by immunocytochemistry. In: ARVO Annual Meeting (Association for Research in Vision and Ophthalmology). Ft Lauderdale, Fla, USA. Investigative Ophthalmology and Visual Science.

Grötzner, S. R., Rocha, F. A. F., Hamassaki-Britto, D., Ventura, D. F. \& Lima, S. M. A. (2005). Density of Rods, S- and UV- Cones in the retina of the turtle investigated by immunocytochemical techniques. In: ARVO Annual Meeting (Association for Research in Vision and Ophthalmology). Ft. Lauderdale. Investigative Ophthalmology and Visual Science. ARVO E-abstract, v. 46. p. 2979.

Gundersen, H. J. G. (1977). Notes on the estimation of the numerical density of arbitrary profiles: the edge effect. J Microsc, 111, 219-223.

Hall, T. A. (1999). BioEdit: a user-friendly biological sequence alignment editor and analysis program for Windows 95/98/NT. Nucl. Acids. Symp. Ser., v. 41, p. 9598.

Hall, S. E. \& Mitchell, D. E. (1991). Grating acuity of cats measured with detection and discrimination tasks. Behavioral Brain Research, 44, 1-9.

Hart, N. S. (2002). Vision in the peafowl (Aves: Pavo cristatus). J Exp Biology, 205, 3925-3935.

Hart, N. S., Partridge, J. C. \& Cuthill, I. C. (2000). Retinal asymmetry in birds. Current Biology, 10, 115-117.

Hart, N. S., Coimbra, J. P., Collin, S. P. \& Westhoff, G. (2012). Photoreceptor types, visual pigments, and topographic specializations in the retinas of Hydrophiid sea snakes. J. Comp. Neurol., 520, 1246-1261. 
Hartmann, P. A., Hartmann, M. T. \& Martins, M. (2009). Ecology of a snake assemblage in the Atlantic Forest of southeastern Brazil. Papéis Avulsos de Zoologia, 49(27), 343-360.

Hauzman, E., Bonci, D. M. O., Grotzner, S. R., Mela, M., Liber, A. M. P., Martins, S. L. \& Ventura, D. F. (2014). Comparative study of photoreceptor and retinal ganglion cell topography and spatial resolving power in Dipsadidae snakes. Brain Behav Evol, 84(in press).

Hawryshyn, C. W., Moyer, H. D., Allison, W. T., Haimberger, T. J. \& McFarland, W. N. (2003). Multidimensional polarization sensitivity in damselfishes. J. Comp. Physiol. A, 189, 213-220

Hayes, B. P. (1984). Cell populations of the ganglion cell layer: displaced amacrine and matching amacrine cells in the pigeon retina. Exp Brain Res, 56, 565-573

Henderson, S. N. (1977). Daylight and its spectrum. New York: Wiley

Hisatomi, O., Satoh, T., Barthel, L. K., Stenkamp, D. L., Raymond, P. A. \& Tokunaga, F. (1996). Molecular cloning and characterization of the putative ultravioletsensitive visual pigment of goldfish. Vision Res, 36, 933-393.

Hodos, W., Leibowitz, R. W. \& Bonbright, J. C. (1976). Near-field visual acuity of pigeons: Effects of head position and stimulus luminance. J Exp Analysis of Behavior, 25, 129-141.

Hokoç, J. N. (1975). Retina e nervo óptico de Didelphis marsupialis aurita: análise quantitativa de células ganglionares e fibras ópticas. Universidade Federal do Rio de Janeiro, Instituto de Biofísica.

Hokoç, J. N., \& Oswaldo-Cruz, E. (1979). A regional specialization in the opossum's retina: quantitative analysis of the ganglion cell layer. J. Comp. Neurology, 183(2), 385-395.

Huelsenbeck, J. P \& Ronquist, F. (2001). MrBayes: Bayesian inference of phylogeny. Bioinformatics, 17, 754-755.

Hughes, E. C. (1971). The sociological eye: Selected papers. Transaction publishers.

Hughes, A. (1975). A quantitative analysis of the cat retinal ganglion cell topography. $J$ Comp Neurology, 163, 107-128.

Hughes, A. (1977). The topography of vision in mammals of contrasting life styles: comparative optics and retinal organization. In: The Visual System in Vertebrates: Handbook of Sensory Physiology, Vol. VII/5. Ed. Crescitelli, F., 613-756. Belrlin, Heidelberg: Springer.

Hunt, D. M., Dulai, K. S., Partridge, J. C., Cottrill, P. \& Bowmaker, J. K. (2001). The molecular basis for spectral tuning of rod visual pigments in deep-sea fish. Journal of Experimental Biology, 204, 3333-3344.

Hunt, D. M., Carvalho, L. S., Cowing, J. A., Parry, J. W., Wilkie, S. E., Davies, W. L. \& Bowmaker, J. K. (2007) Spectral tuning of shortwave-sensitive visual pigments in vertebrates. Photochem Photobiol, 83, 303-310.

Jacobs, G. H. (1993). The distribution and nature of colour vision among the mammals. Biol. Rev., 68, 413-71.

Jacobs, G. H., Fenwick, J. A., Crognale, M. A. \& Deegan II, J. F. (1992). The al cone retina of the garter snake: spectral mechanisms and photopigment. Journal of Comp Physiol A, 170, 701-707.

Johnson, R. L., Grant, K. B., Zankel, T. C., Boehm, M. F., Merbs, S. L., Nathans, J. \& Nakanishi, K. (1993). Cloning and expression of goldfish opsin sequences. Biochemistry, 32, 208-214. 
Kawamura, S. \& Yokoyama, S. (1996). Phylogenetic relationships among short wavelength-sensitive opsins of American chameleon (Anolis carolinensis) and other vertebrates. Vision Res., 36, 2797-2804.

Kawamura, S. \& Yokoyama, S. (1998). Functional characterization of visual and nonvisual pigments of American chameleon (Anolis carolinensis). Vision Res. 38, 37-44.

Kito, Y., Suzuki, T., Azuma, M. \& Sekoguchi, Y. (1968). Absorption spectrum of rhodopsin denatured with acid. Nature, 218, 955-57.

Kolb, H., Nelson, R. Ahnelt, P. \& Cuenca, N. (2001). Cellular organization of the vertebrate retina. Prog Brain Res, 131, 3-26.

Lamb, T. D. \& Simon, E. J. (1977). Analysis of electrical noise in turtle cones. $J$. Physiol., 272, 435-468.

Land, M. F. \& Snyder, A. W. (1985). Cone mosaic observed directly through natural pupil of live vertebrate. Vision Res, 25, 1519-1523.

Lanfear, R., Calcott, B., Ho, S. Y. W. \& Guindon, S. (2012). PartitionFinder: combined selection of partitioning schemes and substitution models for phylogenetic analyses. Mol Biol Evol 29 (6), 1695-1701.

Lillywhite, H. B. \& Henderson, R. W. (1993). Behavioral and functional ecology of arboreal snakes. In: Seigel R.A., Collins J.T. (eds) Snakes: ecology and behaviour. McGraw-Hill, San Francisco, pp 1-48.

Lisney, T. J. \& Collin, S. P. (2008). Retinal ganglion cell distribution and spatial resolving power in elasmobranchs. Brain Behav Evol, 72, 59-77.

Lisney, T. J., Stecyk, K., Kolominsky, J., Schmidt, B. K., Corfield, J. R., Iwaniuk, A. N. \& Wylie, D. R. (2013). Ecomorphology of eye shape and retinal topography in waterfowl (Aves: Anseriformes: Anatidae) with different foraging modes. $J$ Comp Phisiol A, 199, 385-402.

Loew, E. R., Fleishman, L., Foster, R. G. \& Provencio, I. (2002). Visual pigments and oil droplets in diurnal lizard: a comparative study of Caribbean anoles. $J$ Exp Biol., 205, 927-938.

Lythgoe, J. N. (1972). The adaptation of visual pigments to their photic environment. In Handbook of Sensory Physiology, Vol. VII/1 (ed. H.J.A. Dartnall). SpringerVerlag, Berlin. Pp. 566-603.

Lythgoe, J. N. (1979). The ecology of vision. Oxford University Press. New York.

Lythgoe, J. N. \& Partridge, J. C. (1989). Visual pigments and the acquisition of visual information. J. Exp. Biol., 146, 1-20.

Ma, J. X., Kono, M., Xu, L., Das, J., Ryan, J. C., Hazard, 3rd, E. S., Oprian, D. D. \& Crouch, R. K. (2001). Salamander UV cone pigment: sequence, expression, and spectral properties. Vis. Neurosci., 18, 393-399.

Machado, R. A., Bernarde, P. S. \& Morato, S. A. A. (1998). Liophis miliaris. Herp. Rev., 29(1), 45.

Maier, E. J. \& Bowmaker, J. K. (1993). Color-vision in the passeriform bird, Leiothrix lutea: correlation of visual pigment absorbency and oil droplet transmission with spectral sensitivity. J. Comp. Physiol. A, 172, 295-301.

Marchiafava, P. L. (1985). Cell coupling in double cones of the fish retina. Proc. R. Soc. Lond. B, 226, 211-215

Marques , O. A. V. \& Sazima, I. (2004). História natural dos répteis da estação ecológica Juréia-Itatins. In: Estação ecológica Juréia-Itatins: ambiente físico, flora e fauna (O.A.V Marques \& W. Duleba, eds.). Holos, Ribeirão Preto, p. 257-277. 
Marques, O. A. V. \& Souza, V. C. (1993). Nota sobre a atividade alimentar de Liophis miliaris no ambiente marinho (Serpentes, Colubridae). Rev. Bras. Biol., 53(4), 645-648.

Marques, O. A. V., Eterovic, A. \& Sazima, I. (2001). Serpentes da Mata Atlântica: Guia Ilustrado para Serra do Mar. Ribeirão Preto, Holos.

Marques, O. A. V., Eterovic, A. \& Sazima, I. (2004). Snakes of the Brazilian Atlantic forest: an illustrated field guide for the Serra do Mar Range. Holos, Ribeirão Preto.

Marques, O. A. V., Pereira, D. N., Barbo, F. E., Germano, V. J. \& Sawaya, R. J. (2009). Os répteis do Município de São Paulo: diversidade e ecologia da fauna pretérita e atual. Biota Neotrop., 9(2), 139-150.

Marshall, N. J. \& Vorobyev, M. (2003). The design of color signals and color vision in fishes. In Sensory processing in aquatic environments, pp. 194-222. New York, NY: Springer

Marshall, N. J., Jennings, K., McFarland, W. N., Loew, E. R. \& Losey, G. S. (2003). Visual biology of Hawaiian coral reef fishes. II. Colors of Hawaiian coral reef fish. Copeia, 455-466.

Martins, M. (1994). História natural de uma taxocenose de serpentes de mata na região de Manaus, Amazônia Central, Brasil. Tese (Doutorado em Ciências) - Instituto de Biologia, Universidade Estadual de Campinas, Campinas. pp.98

Martins, M. \& Oliveira, M. E. (1993). The snakes of the genus Atractus Wagler (Reptilia: Squamata: Colubridae) from the Manaus region, central Amazonia, Brazil. Zool. Meded., 67, 21-40.

Martins, M. R. C. \& Oliveira, M. E. (1999). Natural history of snakes in forest of the Manaus, central Amazonia, Brazil. Herpetol. Nat. Hist., 6(2), 78-150.

Mass, A. M. \& Supin, A.Ya. (1995). Ganglion cell topography of the retina in the bottlenosed dolphin. Brain, Behavior and Evolution, 45, 257-265.

Marx, H. \& Rabb, G. B. (1972). Phyletic analysis of fifty characters of advanced snakes. Fieldiana: Zoology, Chicago, v. 63, p. 1-320.

McDowell, S. B. (1987) Systematics. In: Seigel R.A. et al. (eds) Snakes: ecology and evolutionary biology. MacMillan. New York, pp 3-50.

McFarland, W. N. (1991). The visual world of coral reef fishes. In The ecology of fishes on coral reefs (ed. P. F. Sale), pp. 16-38. San Diego, CA: Academic Press, Inc

Moritz, G. L., Lim, N. T. L., Neitz, M., Peichl, L. \& Dominy, N. J. (2013). Expression and evolution of short wavelength sensitive opsins in colugos: a nocturnal lineage that informs debate on primate origins. Evol Biol, 40, 542-553

Moroney, M. K. \& Pettigrew, J. D. (1987). Some observations on the visual optics of kingfishers (Aves, Caraciformes, Alcedinidae). J Comp Physiol A, 160, 137149.

Muntz, W. R. \& Gwyther, J. (1989). The visual acuity of octopuses for grating of different orientations. J Exp Biology, 142, 461-464.

Mushinsky, H. R. (1987). Foraging ecology. In: Seigel, R.A.; Collins, J.T. \& Novak, S.S. (eds) Snakes: Ecology and Evolutionary Biology. N. York: Macmillan pp 302-334.

Nathans, J. (1990a). Determinants of visual pigment absorbance: role of changed amino acids in the putative transmembrane segments. Biochemistry, 29, 937-942.

Nathans, J. (1990b). Determinants of visual pigment absorbance: identification of the retinylidene Schiff's base counterion in bovine rhodopsin. Biochemistry, 29, 9746-9752. 
Nathans, J. \& Hogness, D. S. (1983). Isolation, sequence analysis, and intronexon arrangement of the gene encoding bovine rhodopsin. Cell, 34, 807-814.

Nathans, J. \& Hogness, D. S. (1984). Isolation and nucleotide sequence of the gene encoding human rhodopsin. Proc. Natl. Acad. Sci. USA, 81, 4851-4855.

Nathans, J., Thomas, D. \& Hogness, D. S. (1986). Molecular genetics of human color vision: the genes encoding blue, green, and red pigments. Science, 232, 193201.

Ohno, S. (1970). Evolution by Gene Duplication. New York: Springer-Verlag. 160 pp.

Oliveira, J. L. (2001). Ecologia de três espécies de dormideira Sibynomorphus (Serpentes: Colubridae) na Mata Atlântica. Dissertação de Mestrado, Universidade de São Paulo, SP.

Oprian, D. D., Molday, R. S., Kaufman, R. J. \& Khorana, H. G. (1987). Expression of a synthetic bovine rhodopsin gene in monkey kidney cells. Proc. Natl. Acad. Sci. USA, 84, 8874-8878.

Orofino, R. P., Pizzatto, L. \& Marques, O. A. V. (2010). Reproductive biology and food habits of Pseudoboa nigra (Serpentes: Dipsadidae) from the Brazilian cerrado. Phyllomedusa, 9(1), 53-61.

Osorio, D. \& Vorobyev, M. (2005). Photoreceptor sectral sensitivities in terrestrial animals: adaptations for luminance and colour vision. Proc. R. Soc. B, 272, $1745-1752$.

Palczewski, K., Kumasaka, T., Hori, T., Behnke, C. A., Motoshima, H., Fox, B.A., Trong, I. L., Teller, D. C., Okada, T., Stenkamp, R. E., Yamamoto, M. \& Miyano, M. (2000). Crystal structure of rhodopsin: A G proteincoupled receptor. Science, 289, 739-745.

Parry, J. W. L., Poopalasundaram, S., Bowmaker, J. K. \& Hunt, D. M. (2004). A novel amino acid substitution is responsible for spectral tuning in a rodent violetsensitive visual pigment. Biochemistry, 43, 8014-8020.

Peichl, L. (1992). Topography of ganglion cells in the dog and wolf retina. J Comp Neurol, 324, 603-620.

Pepper, R. L. \& Simmons, J. V. (1973). In-air visual acuity of the bottlenose dolphin. Experimental Neurology, 41, 271-276.

Peters, J. A. \& Orejas-Miranda, B. (1970). Catalogue of the neotropical squamata. Bull. U.S. Natl. Mus., 297(2), 1-347. (parte I, Snakes).

Pettigrew, J. D. \& Manger, P. R. (2008). Retinal ganglion cell density of the black rhinoceros (Dicero bicornis): calculating visual resolution. Visual Neuroscience, 25, 215-220.

Pettigrew, J. D., Dreher, B., Hopkins, C. S., McCall, M. J. \& Brown, M. (1988). Peak density and distribution of ganglion cells in the retinae of microchiropteran bats: implications for visual acuity. Brain Behav Evol, 32, 39-56.

Pignatelli, V., Champ, C., Marshall, J. \& Vorobyev, M. (2010). Double cones are used for colour discrimination in the reef fish, Rhinecanthus aculeatus. Biol. Lett., 6, 537-539.

Pizzatto, L. \& Marques, O. A. V. (2002). Reproductive biology of the false coral snake Oxyrhopus guibei (Colubridae) from southeastern Brazil. Amphibia Reptilia.

Prusky, G. T., West, P. W. R. \& Douglas, R. M. (2000). Behavioral assessment of visual acuity in mice ans rats. Vision Research, 40, 2201-2209.

Pyron, R. A., Burbrink, F. T. \& Wiens, J. J. (2013). A phylogeny and revised classification of Squamata, including 4161 species of lizards and snakes. BMC Evolutionary Biology, 13, 93. 
Rambaut, A., Drummond, A. J. (2007). Tracer, Version 1.5. Available at: http://tree.bio.ed.ac.uk/software/tracer/

Ramón y Cajal, S. (1893). La rétine des vertebrés. La Cellule, 9, 17 - 257.

Remy, M. \& Gunturkun, O. (1991). Retinal afferents to the tectum opticum and the nucleus opticus principalis thalami in the pigeon. J Comp Neurology, 305, 5770.

Reymond, L. (1985). Spatial visual acuity of the eagle Aquila audax: A behavioural, optical and anatomical investigation. Vision Research, 25, 1477-1491

Rieke, F. \& Baylor, D. (2000). Origin and functional impact of dark noise in retinal cones. Neuron, 26, 181-186.

Robinson, S. R. (1994). Early vertebrate color vision. Nature, 367, 121.

Rocha, F. A. F., Ahnelt, P. K., Peichl, L., Saito, C. A., Silveira, L. C. L. \& Lima, S. M. A. (2009). The topography of cone photoreceptors in the retina of a diurnal rodent, the agouti (Dasyprocta aguti). Visual Neuroscience, 26, 167-175.

Ronquist, F. \& Huelsenbeck, J. P. (2003). MrBAYES 3: Bayesian phylogenetic inference under mixed models. Bioinformatics, 19, 1572-1574.

Sakmar, T. P., Fahmy, K. (1996). Properties and photoactivity of rhodopsin mutants. Israel J. Chem., 35, 325-37.

Sameshima, M., Uehara, F. \& Ohba, N. (1987). Specialization of the interphotoreceptor matrices around cone and rod photoreceptor cells in the monkey retina, as revealed by lectin cytochemistry. Experimental Eye Research,45, 845-863

Sawaya, R. J., Marques, O. A. V. \& Martins, M. (2008). Composition and natural history of a Cerrado snake assemblage at Itirapina, São Paulo state, southeastern Brazil. Biota Neotropica,8(2), 127-149.

Savitzky, A. H. (1983). Coadapted character complexes among snakes: fossoriality, piscivory, and durophagy. American Zoologist, Seattle, v. 23, p. 397-409.

Sazima, I. (1989). Feeding behavior of the snail-eating snake Dipsas indica. J. Herpetol. 23(4), 464-468.

Sazima, I. \& Haddad, C. F. B. (1992). Répteis da Serra do Japi: notas sobre história natural. In: Morellato, L.P. (org) História Natural da Serra do Japi: ecologia e preservação de uma área florestal no sudeste do Brasil. Ed. da Unicamp pp. 212-237.

Scartozzoni, R. R. (2005). Morfologia de serpentes aquáticas neotropicais: um estudo comparativo. Dissertação de Mestrado, Universidade de São Paulo, São Paulo. p.102.

Schaeffer, R. L., Mendenhall, W. \& Ott, L. (1996). Elementary survey sampling, 5th edn. PWS-Kent, Boston

Schaerer, S. \& Neumeyer, C. (1996) Motion detection in goldfish investigated with the optomotor response is 'color blind'. Vision Res. 36, 4025-4034.

Schiviz, A. N., Ruf, T., Kuebber-Heiss, A., Schubert, C. \& Ahnelt, P. K. (2008). Retinal cone topography of artiodactyl mammals: influence of body height and habitat. $J$ Comp Neurol, 507, 1336-1350.

Schnapf, J. L., Nunn, B. J., Meister, M. \& Baylor, D. A. (1990). Visual transduction in cones of the monkey Macaca fascicularis. J. Physiol, 427, 681-713

Shine, R. (1979). Activity patterns in australian elapid snakes (Squamata: Serpentes: Elapidae). Herpetologica, v. 35, n. 1, p. 1-11.

Sillman, A. J., Govardowskii, V. I., Röhlich, P., Southard, J. A. \& Lowe, E. R. (1997). The photoreceptors and visual pigments of the garter snake (Thamnophis sirtalis): a microspectrophotometric, scanning electron microscopic and immunocytochemical study. J. Comp Physiol. A, 181, 89-101. 
Sillman, A. J., Carver, J. K. \& Loew, E. R. (1999). The photoreceptors and visual pigments in the retina of a boid snake, the ball python (Python regius). J. Exp. Biology, 202, 1931-1938.

Sillman, A. J., Johnson, J. L. \& Loew, E. R. (2001). Retinal photoreceptors and visual pigments in Boa constrictor imperator. J. Exp Zool, 290, 359-365.

Silveira, L. C. L. (1985). Organização do Sistema Visual de Roedores da Amazôna: Óptica Ocular e Distribuição das C [elulas Ganglionares Retinianas. Instituto de Ciências Biológicas, 427.

Silveira, L. C. L., Picanco-Diniz, C. W. \& Oswaldo-Cruz, E. (1989). Distribution and size of ganglion cells in the retina of large Amazon rodents. Vis Neurosci, 2, 221-235.

Sivak, J. G. (1975). Accommodative mechanisms in aquatic vertebrates. In: Ali MA, ed. Vision in Fishes. New York: Plenum Press. 289-297

Sivak, J. G. (1976). The accommodative significance of the 'ramp' retina of the eye of the stingray. Vision Res, 16, 531-534.

Sivak, J. G. (1978). Optical characteristics of the eye of the spiny dogfish (Squalus acanthias). Rev Can Biol, 37, 209-217.

Smith, G. \& Atchison, D. A. (1997). The Eye and Visual Optical Instrument. New York: Cambridge University Press.

Smith, R. L., Nishimura, Y. \& Raviola, G. (1985). Interreceptor junction in the double cone of the chicken retina. J. Submicrosc. Cytol. Pathol. 17, 183-186.

Snyder, A. W. \& Miller, W. H. (1977). Photoreceptor diameter and spacing for highest resolving power. J Opt Soc Am, 67, 696-698.

Stockman, A. \& Sharpe, L. T. (2000). The spectral sensitivities of the middle- and longwavelength-sensitive cones derived from measurements in observers of known genotype. Vision Res. 40(13), 1711-37.

Stone, J. (1983). Parallel processing in the visual system. London, Plenum.

Stone, J. \& Halasz, P. (1989). Topography of the retina in the elephant Loxodonta africana. Brain Behav Evol, 34, 84-95.

Strader, C. D., Fong, T. M., Tota, M. R. \& Underwood, D. (1994). Structure and function of G protein-coupled receptors. Annu. Rev. Biochem., 63, 101-32.

Strüssmann, C. \& Sazima, I. (1993). The snake assemblage of the Pantanal at Poconé western Brazil: faunal composition and ecological summary. Stud. Neotrop. Fauna Environ. 28(3), 157-168.

Studier, F. W., Rosenberg, A. H., Dunn, J. J. \& Dubendorff, J. W. (1990). Use of T7 RNA polymerase to direct expression of cloned genes. Methods Enzymol 185, 60-89.

Supin, A. Y., Popov, V. V. \& Mass, A. M. (2001). The sensory physiology of aquatic mammals. Boston, MA: Kluwer Academic Publishers

Szel, A., Lukats, A., Fekete, T., Szepessy, Z. \& Rohlich, P. (2000). Photoreceptor distribution in the retinas of subprimate mammals. J. Opt. Soc. Am. A, 17, 568579.

Takase, E., Souza, J. M. \& Ventura, D. F. (1998). Oil droplet types in the hummingbird Eupetomena macroura macroura. In: Investigative Ophthalmology \& Visual Science Annual Meeting, Fort Lauderdale. Investigative Ophthalmology \& Visual Science, 1998. v. 39. p. 561-561.

Thompson, I. (1991). Considering the Evolution of Vertebrate Neural Reina. In. CronlyDillon, J. \& Gregory, R.L. (eds). Vision and Visual Dysfunction Vol 2: Evolution of the Eye and Visual System. Macmilla Press. pp. 
Thomas, L. P. \& Buck, S. L. (2006). Foveal and extra-foveal influences on rod hue bisases. Visual Neuroscience, 23, 539-542.

Timney, B. \& Keil, K. (1992). Visual acuity in the horse. Vision Research, 32, 22892293.

Torello-Viera, N. F. (2014). Atividade diária de dipsadídeos neotropicais. Dissertação de Mestrado, Universidade Estadual Paulista "Júlio de Mesquita Filho". São José do Rio Preto p. 59.

Trezise, A. E. O. \& Collin, S. P. (2005). Opsins: evolution is waiting. Current Biology, 15(19), R794-6.

Tudge, C. (2000) The Variety of Life. Oxford University Press, Oxford

Turner, P. L. \& Mainster, M. A. (2008) Circadian photoreception: ageing and the eye's important role in systemic health. British Journal of Ophthalmology, 92, 14391444.

Ullmann, J. F. P., Moore, B. A., Temple, S. H., Fernández-Juricic, E. \& Collin, S. P. (2012): The retinal wholemount technique: a window to understanding the brain and behaviour. Brain Behav Evol, 79, 26-44

Underwood, G. (1967). A Contribution to the Classification of Snakes. London. Trustees of the British Museum (Natural History).

Underwood, G. (1970). The eye. In: Gans, C. \& Parson, T.S. (eds) Biology of the Reptilia, vol. 2, Morphology B. Academic Press, New York, pp 1 - 97

Vaney, D. I. \& Hughes, A. (1976). The rabbit optic nerve: fibre diameter spectrum, fibre count, and comparison with a retinal ganglion cell count. J Comp Neurology, 170, 241-251.

Ventura, D. F., De Souza, J. M., Devoe, R. D. \& Zana, Y. (1999). Ultraviolet responses in the retina of the turtles. Vis Neurosci, 16, 191-204.

Vidal, N. \& Hedges, S. B. (2004). Molecular evidence for a terrestrial origin of snakes. Proc. R. Soc. Lond. B (Suppl.), 271, S226-S229.

Vihtelic, T. S., Doro, C. J. \& Hyde, D. R. (1999). Cloning and characterization of six zebrafish photoreceptor opsin cDNAs and immunolocalization of their corresponding proteins. Vis. Neurosci., 16, 571-585.

Viitala, J., Korpimaki, E., Palokangas, P. \& Kolvula, M. (1995). Attraction of kestrels to vole scent marks visible in ultraviolet light. Nature, 373, 425-427.

Vitt, L. J. \& Vangilder, L. D. (1983). Ecology of a snake community in northeastern Brazil. Amphibia-Reptilia, 4, 273-296.

Vorobyev, M. (2003). Coloured oil droplets enhance colour discrimination. Proc. $R$. Soc. Lond. B, 270, 1255-1261.

Vorobyev, M. \& Osorio, D. (1998). Receptor noise as a determinant of colour thresholds. Proc. R. Soc. Lond. B 265, 351-358.

Wagner, H. J., Fröhlich, E., Negishi, K. \& Collin, S. P. (1998). The eyes of deep-sea fish. II. Functional morphology of the retina. Prog Retin Eye Res, 17, 637-685.

Wald, G. (1935). Carotenoids and the visual cycle. J. Gen. Physiol., 19, 351-71.

Wald, G. (1955). The photoreceptor process in vision. Am. J. Ophthalmol., 40, 18-41.

Wald, G. (1968). Molecular basis of visual excitation. Science, 162, 230-39.

Walls, G. L. (1934). The reptilian retina. I. A new concept in visual cell evolution. Am J Ophthalmol, 17, 892-915.

Walls, G. L. (1940). The pigment of the vertebrate lens. Science, 91, 172.

Walls, G. L. (1942). The vertebrate eye and its adaptative radiation. Cranbook Inst of Science, Bloomfield Hills. 
Wang, Y., Macke, J. P., Merbs, S. L., Zack, D. J., Klaunberg, B., Bennett, J., Gearhart, J. \& Nathans, J. (1992). A locus control region adjacent to the human red and green visual pigment genes. Neuron, 9, 429-440.

Wässle, H., Peichl, L. \& Boycott, B. B. (1981). Morphology and topography of on-and off-alpha cells in the cat retina. Proc $R$ Soc Lond B Biol Sci, 212, 157-175.

West, M. J., Slomianka, L. \& Gundersen, H. J. (1991): Unbiased stereological estimation of the total number of neurons in the subdivisions of the rat hippocampus using the optical fractionator. Anat Rec, 231, 482-497.

Wilkie, S. E., Robinson, P. R., Cronin, T. W., Poopalasundaram, S., Bowmaker, J. K. \& Hunt, D. M. (2000). Spectral tuning of avian violet- and ultraviolet-sensitive visual pigments. Biochemistry, 39, 7895-7901.

Wong, R. (1989). Morphology and distribution of neurons in the retina of the American garter snake (Thamnophis sirtalis). The Journal of Comparative Neurolog., 283, 597-601.

Wong, R. O. L. \& Hughes, A. (1987). The morphology, number, and distribution of a large population of confirmed displaced amacrine cells in the adult cat retina. $J$ Comp Neurology, 255, 159-177.

Yang, C. G. Y. (2010). Rod-like properties of small single cones: transmutated photoreceptors of garter snakes (Thamnophis proximus). Masters thesis. Toronto: University of Toronto

Yokoyama, S. (1996). Molecular evolution of retinal and nonretinal opsins. Genes Cells, 1, 787-794.

Yokoyama, S. (1997). Molecular genetic basis of adaptative selection: examples from color vision in Vertebrates. Annu. Rev. Genet., 31, 315-36.

Yokoyama, S. (2000). Molecular evolution of vertebrate visual pigments. Prog. Retin. Eye Res, 19(4), 385-419.

Yokoyama, S. (2002). Molecular evolution of color vision in vertebrates. Gene, 300, 6978.

Yokoyama, S. (2008). Evolution of Dim-Light and Color Vision Pigments. Annu. Rev. Genomics Hum. Genet., 9, 259-82.

Yokoyama, S. \& Blow, N. S. (2001). Molecular evolution of the cone visual pigments in the pure rod-retina of the nocturnal gecko, Gekko gekko. Gene, 276, 117-125.

Yokoyama, S. \& Radlwimmer, F. B. (1999). The molecular genetics of red and green color vision in mammals. Genetics, 153, 919-932.

Yokoyama, S., Radlwimmer, F. B. \& Blow, N. S. (2000). Ultraviolet pigments in birds evolved from violet pigments by a single amino acid change. Proc. Natl. Acad. Sci. USA, 97, 7366-7371.

Yokoyama, S. \& Starmer, W. T. (1996). Evolution of the G-protein-coupled receptor superfamily. In: Human Genome Evolution, ed. M Jackson, T Strachan, G Dover, pp. 93-119. Oxford: BIOS Sci.

Yokoyama, S. \& Yokoyama, R. (1996). Adaptive evolution of photoreceptors and visual pigments in vertebrates. Annu. Rev. Ecol. Syst., 27, 534-67.

Yokoyama, S., Radlwimmer, F. B. \& Kawamura, S. (1998). Regeneration of ultraviolet pigments of vertebrates. FEBS Lett, 423, 155-158.

Yokoyama, S. \& Shi, Y. (2000). Genetics and evolution of ultraviolet vision in vertebrates. FEBS Lett., 486, 167-172.

Yokoyama, S., Zhang, H., Radlwimmer, F. B. \& Blow, N. S. (1999) Adaptive evolution of color vision of the Comoran coelacanth (Latimeria chalumnae). Proceedings of the National Academy of Sciences, USA, 96, 6279-6284. 
Zaher, H., Grazziotin, F. G., Cadle, J. E., Murphy, R. W., Moura-Leite, J. C. \& Bonatto, S. L. (2009). Molecular phylogeny of advanced snakes (Serpentes, Caenophidia) with an emphasis on South American Xenodontines: a revised classification and descriptions of new taxa. Papeis Avulsos de Zoologia, 49, 115-153.

Zhao, X., Haeseleer, F., Fariss, R. N., Huang, J., Baehr, W., Milam, A. H. \& Palczewski, K. (1997) Molecular cloning and localization of rhodopsin kinase in the mammalian pineal. Vis. Neurosci., 14, 225-232

Zwickl, D. J. (2006). GARLI, Genetic Algorithm for Rapid Likelihood Inference, Version 0.942. Available at www.bio.utexas.edu/faculty/antisense/garli/ Garli.html 
9. ANEXOS

Anexo 1.

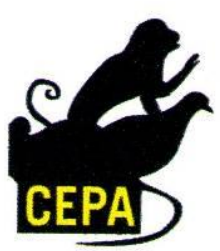

\section{COMISSÃO DE ÉTICA EM PESQUISA COM ANIMAIS \\ Instituto de Psicologia \\ USP}

\section{CERTIFICADO}

Certificamos que o projeto registrado sob o número 006.2010, para uso de animais em experimentação, intitulado "Ecologia Visual de Serpentes Caenophidia”, sob a Coordenação da Profa. Dora Selma Fix Ventura, e a participação da pesquisadora Einat Hauzman foi aprovado pela Comissão de Ética em Pesquisa com Animal (CEPA) do Instituto de Psicologia, em reunião de 21 de junho de 2009.

In signing we certify that the project "Visual Ecology of Caenophidian Snakes", number 006.2010, submitted by Dora Selma Fix Ventura and Einat Hauzman, master or doctoral student) was approved by the Committee on Ethical Research on Animals (CEPA) of Institute of Psychology of University of São Paulo.

São Paulo, 21 de Junho de 2010.
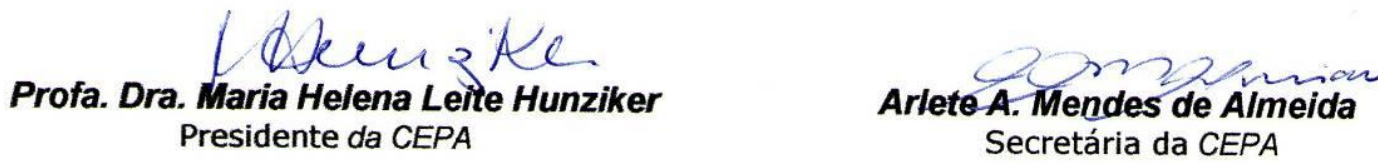


\section{Anexo 2.}

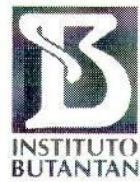

\section{COMISSÃO DE ÉTICA NO USO DE ANIMAIS}

INSTITUTO BUTANTAN

Av. Vital Brazil, 1500, CEP 05503-900, São Paulo, SP, Brazil

Telefone: (55) (011) 3726-7222 ramal 2106 - Fax: (55) (011) 3726-1505

\section{CERTIFICADO}

Certificamos que o Projeto intitulado "Ecologia Visual de Serpentes Caenophidia" protocolo n $^{\circ} 777 / 10$, sob a responsabilidade de Francisco Luis Franco e Einat Hauzman, está de acordo com os Princípios Éticos na Experimentação Animal adotado pelo Colégio Brasileiro de Experimentação Animal (COBEA), e foi aprovado pela COMISSÃO DE ÉTICA NO USO DE ANIMAIS DO INSTITUTO BUTANTAN (CEUAIB) em reunião de 14/10/2010.

\begin{tabular}{|c|l}
\hline $\begin{array}{c}\text { Vigência do Projeto: } \\
10 / 2010-08 / 2013\end{array}$ & \multicolumn{1}{c}{ N $^{\circ}$ de animais/espécie } \\
\hline Laboratório de Herpetologia/Coleção & 8 serpentes Atractus sp \\
& 8 serpentes Chironius laevicolis \\
& 8 serpentes C. bicarinatus \\
& 8 serpentes Dipsas sp \\
& 8 serpentes Echinantera undulata \\
& 8 serpentes E. bilineata \\
& 8 serpentes Erythrolamprus aesculapii \\
8 serpentes Helicops sp \\
& 8 serpentes Imantodes cenchoa \\
& 8 serpentes Liophis miliaris \\
& 8 serpentes L. poecilogyrus \\
& 8 serpentes Oxyrhopus sp \\
& 8 serpentes Sibynomorphus mikanii \\
& 8 serpentes S. neuwiedii \\
& 8 serpentes Spilotes pulatus \\
& 8 serpentes Tomodon dorsatus \\
& 8 serpentes Thamnodynastes sp \\
& 01 serpente Liotyphlops beui \\
& 01 serpente Anilius scytale \\
& 02 serpentes Boa contrictor \\
8 serpentes Epicrates cencria
\end{tabular}

De acordo:

Dr. Otav Azevedo Mercadante

Diretor do Instịtuto Butantan

São Paulo, 15 de outubro de 2010.

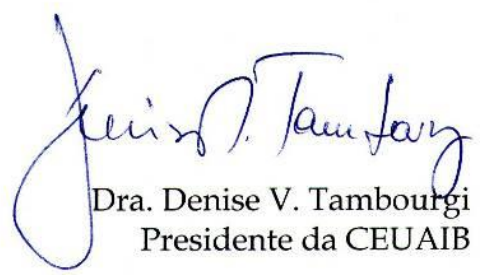




\title{
Anexo 3.
}

\author{
ALBERT EINSTEIN \\ INSTITUTO ISRAELITA DE \\ ENSINOE PESQUISA
}

São Paulo, 01 de julho de 2011

Ref. CEUA/Einstein No 1359-11

Título: Ecologia visual de Serpentes Caenophidia.

Pesquisador Responsável: Daniela Maria Oliveira Bonci

Ilma. Sra.

Daniela Maria Oliveira Bonci

O Comitê de Ética no Uso de Animais de Experimentação (CEUA) analisou e aprovou o curso/projeto de pesquisa em questão, coordenado por V.Sa.

Aproveitamos a oportunidade para informar que:

- O (treinamento ou pesquisa) deve ser desenvolvido conforme delineado no processo aprovado.

- O CEUA/Einstein deve ser informado de todos os fatos relevantes que alterem o curso normal do estudo ou treinamento. É papel do responsável assegurar medidas imediatas adequadas frente a eventos não previstos.

- Eventuais modificações ou emendas ao processo devem ser apresentadas ao CEUA/Einstein de forma clara e sucinta, identificando a parte a ser modificada e suas justificativas;

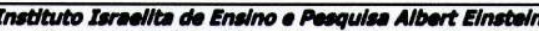

Av. Albert Einstein, 627-Morumbl - SAlo Paulo - SP - 05652-000 - Brasil

Tel: (55-11) 2151-3729 Fax: (55 - 11) 2151-0273

Internet: www.einstein.br e-mall: cep@einstein.br 


\section{Anexo 4.}

Dados das serpentes obtidas e número de tombo da Coleção Herpetológica Alphonse Richard Hoge, do Instituto Butantan, São Paulo.

\begin{tabular}{|c|c|c|c|c|c|}
\hline Espécie & Tombo & CRC (mm) & $\mathrm{CC}(\mathrm{mm})$ & m (g) & sexo \\
\hline \multirow{5}{*}{ Atractus pantostictus } & 78668 & 295 & 40 & 9,7 & $\mathrm{M}$ \\
\hline & 79393 & 448 & 45 & 23,8 & $\mathrm{~F}$ \\
\hline & 82695 & 293 & 28 & 9,9 & $\mathrm{~F}$ \\
\hline & 84881 & 330 & 45 & 10 & M \\
\hline & 85250 & 402 & 18 & & $\mathrm{~F}$ \\
\hline \multirow{4}{*}{ Atractus reticulatus } & 78717 & 342 & 42 & 15,4 & $\mathrm{M}$ \\
\hline & 79284 & 238 & 38 & 6,4 & M \\
\hline & 79890 & 220 & 30 & 6,9 & M \\
\hline & 84455 & 298 & 38 & 12 & $\mathrm{~F}$ \\
\hline \multirow{8}{*}{ Chironius bicarinatus } & 78395 & 845 & 527 & 137 & $\mathrm{~F}$ \\
\hline & 78410 & 855 & 550 & 168 & $\mathrm{~F}$ \\
\hline & 78562 & 960 & 517 & 149 & $\mathrm{~F}$ \\
\hline & 78599 & 1000 & 527 & 202 & $\mathrm{~F}$ \\
\hline & 79151 & 750 & 462 & 92 & $\mathrm{~F}$ \\
\hline & 83980 & 1157 & 655 & 327 & M \\
\hline & 84534 & 818 & 463 & 108 & $\mathrm{~F}$ \\
\hline & 84622 & 823 & 515 & 98 & M \\
\hline \multirow[t]{2}{*}{ Dipsas albifrons } & 79753 & 410 & 144 & 17 & $\mathrm{~F}$ \\
\hline & 79996 & 650 & 182 & 59 & $\mathrm{~F}$ \\
\hline \multirow[t]{2}{*}{ Dipsas bucephala } & 84190 & 702 & 132 & 48 & $\mathrm{~F}$ \\
\hline & 84191 & 570 & 180 & 26 & M \\
\hline \multirow{2}{*}{ Dipsas indica } & 79465 & 570 & 190 & 30 & M \\
\hline & 79229 & 595 & 177 & 40 & $\mathrm{~F}$ \\
\hline \multirow{2}{*}{ Dipsas petersi } & 78923 & 630 & 250 & 40 & $\mathrm{M}$ \\
\hline & 78922 & 535 & 192 & 30 & $\mathrm{~F}$ \\
\hline Echinantera cephalostriata & 84734 & 540 & 210 & & $\mathrm{~F}$ \\
\hline \multirow{5}{*}{ Echinantera undulata } & 79228 & 372 & 165 & 17 & $\mathrm{~F}$ \\
\hline & 79285 & 374 & 173 & 19 & M \\
\hline & 79395 & 435 & 193 & 24 & $\mathrm{~F}$ \\
\hline & 79888 & 427 & 215 & 29 & M \\
\hline & 84438 & 445 & 153 & 36 & $\mathrm{~F}$ \\
\hline \multirow{8}{*}{ Erythrolamprus aesculapii } & 78368 & 315 & 45 & & $\mathrm{~F}$ \\
\hline & 78374 & 500 & 262 & 21 & $\mathrm{~F}$ \\
\hline & 78643 & 869 & 135 & 145 & $\mathrm{~F}$ \\
\hline & 78720 & 544 & 83 & 40 & M \\
\hline & 82694 & 326 & 50 & 18 & $\mathrm{~F}$ \\
\hline & 83221 & 568 & 76 & 30 & $\mathrm{~F}$ \\
\hline & 83946 & 745 & 83 & 71 & $\mathrm{~F}$ \\
\hline & 85206 & 612 & 92 & 60 & M \\
\hline \multirow{8}{*}{ Erythrolamprus miliaris } & 78646 & 395 & 55 & 25 & $\mathrm{M}$ \\
\hline & 78669 & 320 & 61 & 13 & M \\
\hline & 78902 & 667 & 170 & 121 & M \\
\hline & 79227 & 413 & 105 & 30 & $\mathrm{~F}$ \\
\hline & 79154 & 557 & 118 & 57 & M \\
\hline & 79227 & 568 & 145 & 60 & $\mathrm{~F}$ \\
\hline & 79288 & 710 & 177 & 102 & $\mathrm{~F}$ \\
\hline & 85385 & 615 & 101 & 116 & $\mathrm{~F}$ \\
\hline \multirow{6}{*}{ Erythrolamprus poecilogyrus } & 78367 & 180 & 42 & 4 & $\mathrm{M}$ \\
\hline & 79567 & 410 & 92 & 28 & M \\
\hline & 79891 & 352 & 80 & 24 & M \\
\hline & 79995 & 347 & 80 & 18 & M \\
\hline & 82797 & 495 & 108 & 44 & $\mathrm{~F}$ \\
\hline & 84527 & 620 & 120 & 84 & $\mathrm{~F}$ \\
\hline
\end{tabular}




\begin{tabular}{|c|c|c|c|c|c|}
\hline Espécie & Tombo & CRC (mm) & $\mathrm{CC}(\mathrm{mm})$ & m (g) & sexo \\
\hline \multirow{9}{*}{ Helicops modestus } & 79283 & 312 & 130 & 29 & $\mathrm{M}$ \\
\hline & 79286 & 210 & 65 & 9 & M \\
\hline & 79845 & 534 & 153 & 100 & $\mathrm{~F}$ \\
\hline & 82562 & 357 & 120 & 36 & M \\
\hline & 82658 & 290 & 123 & 20 & M \\
\hline & 82699 & 425 & 128 & 44 & M \\
\hline & 84067 & 510 & 145 & 119 & $\mathrm{~F}$ \\
\hline & 85383 & 296 & 117 & 20 & M \\
\hline & 85384 & 301 & 127 & 20 & M \\
\hline Oxyrhopus clathratus & 82698 & 1080 & 182 & 176 & $\mathrm{~F}$ \\
\hline \multirow{8}{*}{ Oxyrhopus guibei } & 78369 & 794 & 198 & 171 & $\mathrm{~F}$ \\
\hline & 78399 & 869 & 198 & 137 & $\mathrm{~F}$ \\
\hline & 78409 & 700 & 190 & 85 & M \\
\hline & 78446 & 762 & 95 & 92 & M \\
\hline & 78465 & 714 & 185 & 91 & M \\
\hline & 78463 & 885 & 195 & 177 & $\mathrm{~F}$ \\
\hline & 84528 & 990 & 220 & 220 & $\mathrm{~F}$ \\
\hline & 84623 & 900 & 192 & 166 & $\mathrm{~F}$ \\
\hline \multirow{6}{*}{ Sibynomorphus mikanii } & 78370 & 500 & 95 & 49 & $\mathrm{~F}$ \\
\hline & 78397 & 410 & 79 & 18 & $\mathrm{~F}$ \\
\hline & 78408 & 465 & 100 & 37 & $\mathrm{~F}$ \\
\hline & 78448 & 500 & 97 & 50 & $\mathrm{~F}$ \\
\hline & 78718 & 580 & 220 & 66 & $\mathrm{~F}$ \\
\hline & 84163 & 520 & 115 & 39 & $\mathrm{~F}$ \\
\hline \multirow{8}{*}{ Sibynomorphus neuwiedii } & 78414 & 643 & 157 & 54 & $\mathrm{~F}$ \\
\hline & 78415 & 630 & 152 & 78 & $\mathrm{~F}$ \\
\hline & 78450 & 553 & 145 & 39 & $\mathrm{~F}$ \\
\hline & 78719 & 493 & 150 & 21 & M \\
\hline & 79329 & 510 & 154 & 29 & $\mathrm{~F}$ \\
\hline & 79330 & 475 & 146 & 23 & M \\
\hline & 79331 & 400 & 125 & 16 & M \\
\hline & 82696 & 447 & 150 & 15 & M \\
\hline \multirow{3}{*}{ Spilotes pullatus } & 82551 & 1649 & 447 & 538 & $\mathrm{~F}$ \\
\hline & 84439 & 1055 & 460 & 670 & $\mathrm{~F}$ \\
\hline & 85023 & 1445 & 508 & 1032 & M \\
\hline Taeniophallus persimilis & 84735 & 320 & 110 & & $\mathrm{~F}$ \\
\hline \multirow{8}{*}{ Tomodon dorsatus } & 78398 & 480 & 130 & 27 & $\mathrm{~F}$ \\
\hline & 78396 & 480 & 150 & 32 & $\mathrm{~F}$ \\
\hline & 78407 & 565 & 247 & 44 & $\mathrm{~F}$ \\
\hline & 78416 & 505 & 105 & 35 & M \\
\hline & 78449 & 520 & 165 & 32 & M \\
\hline & 78447 & 475 & 162 & 31 & M \\
\hline & 78464 & 554 & 170 & 39 & M \\
\hline & 83947 & 540 & 165 & 86 & $\mathrm{~F}$ \\
\hline Thamnodynastes hypoconia & 84621 & 432 & 152 & 24 & M \\
\hline Thamnodynastes natererii & 78373 & 285 & 100 & 8,4 & $\mathrm{M}$ \\
\hline \multirow{8}{*}{ Thamnodynastes strigatus } & 78372 & 310 & 297 & 10 & $\mathrm{~F}$ \\
\hline & 78411 & 273 & 65 & 13 & $\mathrm{~F}$ \\
\hline & 79287 & 275 & 72 & 11 & M \\
\hline & 79332 & 312 & 90 & 17 & M \\
\hline & 79394 & 442 & 145 & 37 & M \\
\hline & 79568 & 332 & 83 & 21 & $\mathrm{~F}$ \\
\hline & 85225 & 620 & 150 & & $\mathrm{~F}$ \\
\hline & 85226 & 675 & 175 & & M \\
\hline
\end{tabular}

CRC, comprimento rostro cloacal; CC, comprimento caudal; m, massa. 


\section{Anexo 5.}

Espécies utilizadas nas análises filogenéticas e números de acesso no Genbank.

\begin{tabular}{|c|c|c|c|}
\hline Opsina & Nome comum & Espécie & No GenBank \\
\hline \multirow{19}{*}{ Rh1 } & Salamandra & Ambystoma tigrinum & Q90245 \\
\hline & Lagarto & Anolis carolinensis & P41591.1 \\
\hline & Boi & Bos taurus & NM_001014890.1 \\
\hline & Peixe dourado & Carassius auratus & L11863 \\
\hline & Pomba & Columba livia & АH007730.1 \\
\hline & Peixe-zebra & Danio rerio & NP_571287 \\
\hline & Galinha & Gallus gallus & P22328 \\
\hline & Lampreia & Geotria australis & AAR14682 \\
\hline & Humano & Homo sapien & NP_00530.1 \\
\hline & Camundongo & Mus musculus & NP_663358 \\
\hline & Lungfish & Neoceratodus forsteri & EF526295.1 \\
\hline & Ornitorrinco & Ornithorhynchus anatinus & ABN43074.1 \\
\hline & Gecko & Phelsuma madagascariensis & AF074044.1 \\
\hline & Serpente (píton) & Python regius & FJ497236.1 \\
\hline & Marsupial & Sminthopsis crassicaudata & Q8HY69 \\
\hline & Mandarim & Taeniopygia guttata & AF222329 \\
\hline & Lagarto & Uta stansburiana & DQ100323.1 \\
\hline & Serpente & Xenopeltis unicolor & FJ497233.1 \\
\hline & Rã & Xenopus laevis & AAC42232.1 \\
\hline \multirow{10}{*}{ Rh2 } & Lagarto & Anolis carolinensis & AF134189 \\
\hline & Peixe-cego & Astyanax mexicanus & AAB 32221 \\
\hline & Pomba & Columba livia & АH007731.1 \\
\hline & Peixe-zebra & Danio rerio & Q9W6A6 \\
\hline & Galinha & Gallus gallus & P28683 \\
\hline & Lampreia & Geotria australis & AAR14683 \\
\hline & Celacanto & Latimeria chalumnae & AF131258 \\
\hline & Lungfish & Neoceratodus forsteri & EF526296.1 \\
\hline & Mandarim & Taeniopygia guttata & NM_001076696.1 \\
\hline & Lagarto & Uta stansburiana & DQ100324.1 \\
\hline \multirow{19}{*}{ SWS1 } & Salamandra & Ambystoma tigrinum & AF038948.1 \\
\hline & Lagarto (camaleao) & Anolis carolinensis & АH007736.1 \\
\hline & Boi & Bos tauros & NP_776992.1 \\
\hline & Peixe dourado & Carassius auratus & Q90309 \\
\hline & pomba & Columba livia & AH007798.1 \\
\hline & Peixe zebra & Danio rerio & Q9W6A9 \\
\hline & Galinha & Gallus gallus & P28684 \\
\hline & Gecko & Gekko gekko & P35357 \\
\hline & Lampreia & Geotria australis & AY366495.1 \\
\hline & Humano & Homo sapiens & P03999 \\
\hline & Camundongo & Mus musculus & P51491 \\
\hline & Lagarto & Phelsuma madagascarensis & AAD45183 \\
\hline & Lungfish & Neoceratodus forsteri & EF526298.1 \\
\hline & Serpente (piton) & Python regius & FJ497237.1 \\
\hline & Marsupial & Sminthopsis crassicaudata & AY442173.1 \\
\hline & Mandarim & Taeniopygia guttata & AF222331 \\
\hline & Lagarto & Uta stansburiana & DQ100325.1 \\
\hline & Serpente & Xenopeltis unicolor & FJ497234.1 \\
\hline & Rã & Xenopus laevis & P51473 \\
\hline \multirow{10}{*}{ SWS2 } & Salamander & Ambystoma tigrinum & AF038946 \\
\hline & Peixe-cego & Astyanax mexicanus & AAB28911 \\
\hline & Pomba & Columba livia & AH007799.1 \\
\hline & Peixe-zebra & Danio rerio & BAC 24133.1 \\
\hline & Galinha & Gallus gallus & P28682 \\
\hline & Lampreia & Geotria australis & AAR14681 \\
\hline & Ornitorrinco & Ornithorhynchus anatinus & ABN43075.1 \\
\hline & Mandarim & Taeniopygia guttata & NM_001076697.1 \\
\hline & Lagarto & Uta stansburiana & DQ100326.1 \\
\hline & Rã & Xenopus laevis & AAO38746 \\
\hline
\end{tabular}




\begin{tabular}{l|ccc}
\hline \multirow{7}{*}{ Salamandra } & Ambystoma tigrinum & AF038947 \\
& Lagarto & Anolis carolinensis & P41592 \\
& Boi & Bos taurus & AAG49893 \\
& Peixe dourado & Carassius auratus & L11867 \\
& Peixe zebra & Danio rerio & NM_001002443 \\
& Galinha & Gallus gallus & P22329 \\
& Gecko & Gekko gekko & P35358 \\
& Lampreia & Geotria australis & AY366491 \\
& Humano & Homo sapien & P04001 \\
& Camundongo & Mus musculus & O35599 \\
& Ornitorrinco & Ornithorhynchus anatinus & ABN43076.1 \\
& Lagarto & Phelsuma madagascarensis & AAD25917.1 \\
& Serpente (píton) & Python regius & EF526238.1 \\
& Lungfish & Neoceratodus forsteri & AY430816.1 \\
& Marsupial & Sminthopsis crassicaudata & AF222333 \\
& Mandarim & Taeniopygia guttata & DQ129869.1 \\
& Lagarto & Uta stansburiana & FJ497235.1 \\
& Serpente & Xenopeltis unicolor & U90895 \\
\hline
\end{tabular}


Anexo 6. Alinhamento das sequências de aminoácidos dos três pigmentos visuais de serpentes e da rodopsina bovina, com os sítios específicos relacionados ao deslocamento espectral destacados em verde (RH1), vermelho (LWS) e violeta (SWS1).
10.1....1
$\ldots+1 \ldots .130$

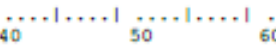
70

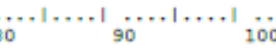
10.1....1 120
${ }_{13} 30$
$40^{3.1 \cdots+1} 130$
$\ldots .1 \ldots$

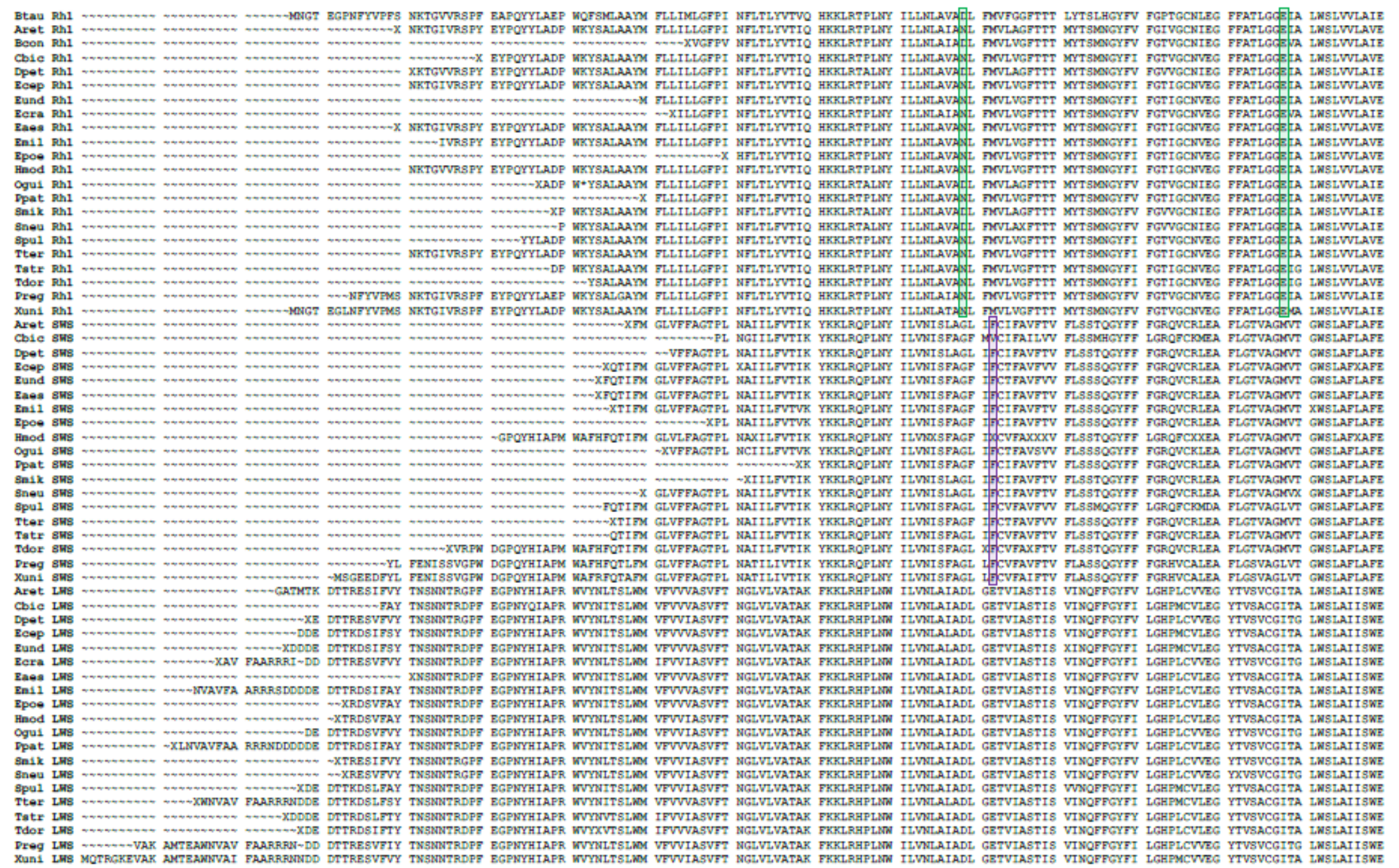




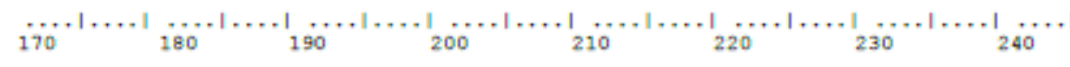
$2300+\cdots+260$ 270 280 $\dddot{90}$ 300 310 320

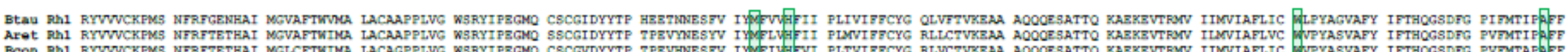

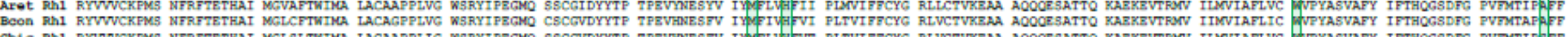

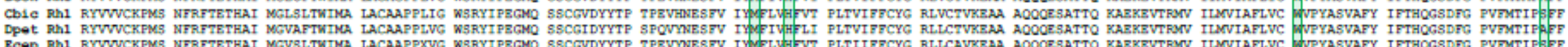

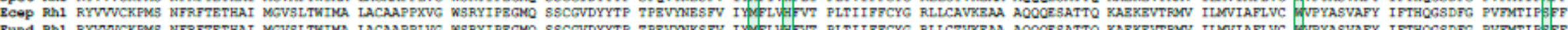

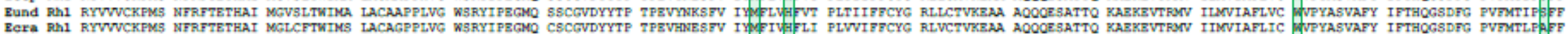

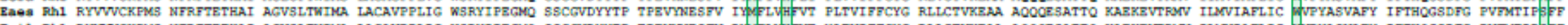

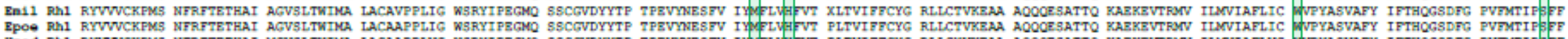

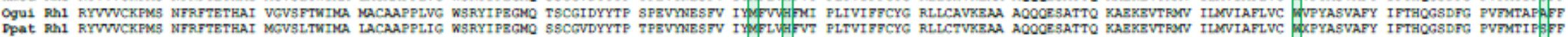

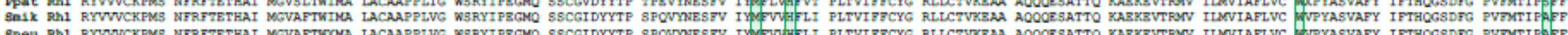

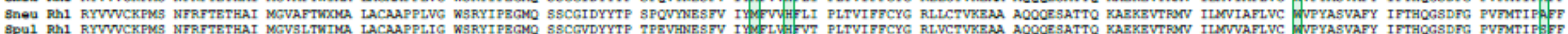

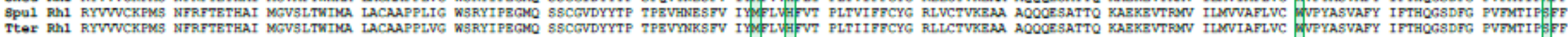

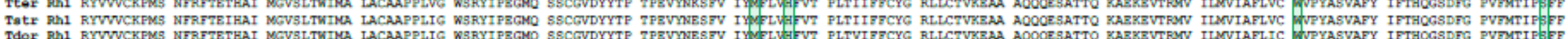

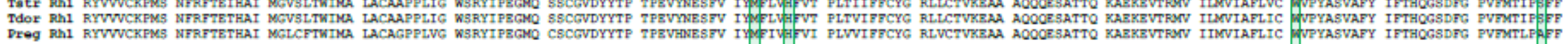

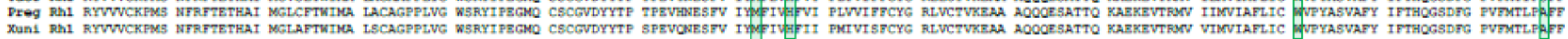

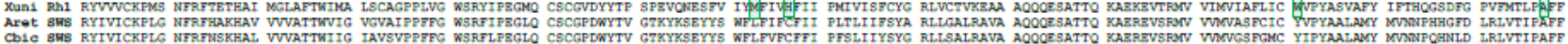

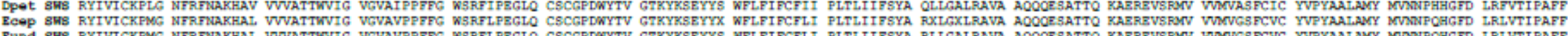

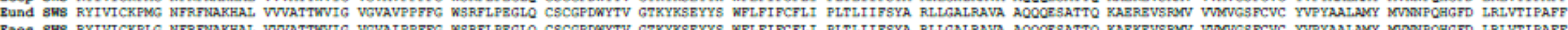

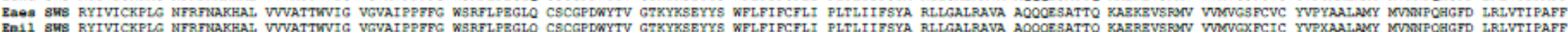

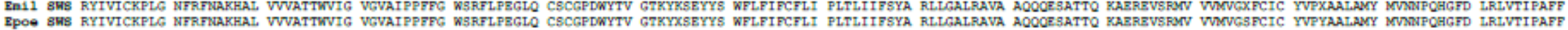

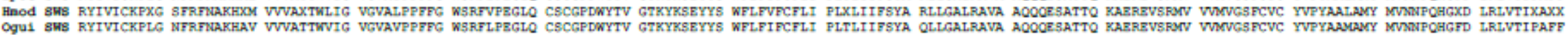

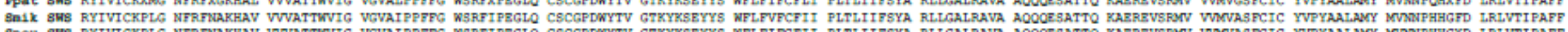

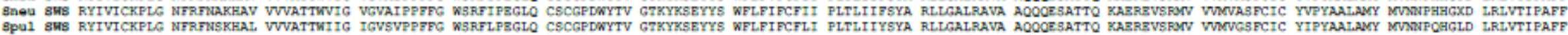

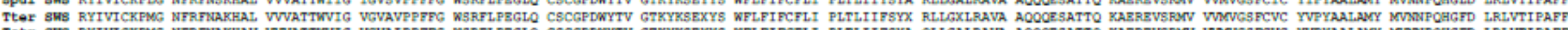

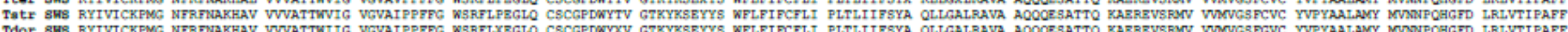

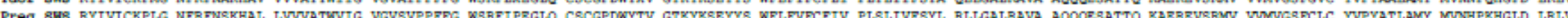

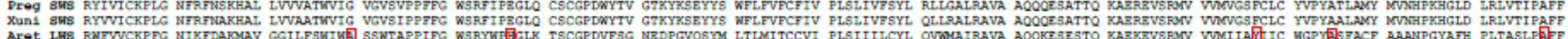

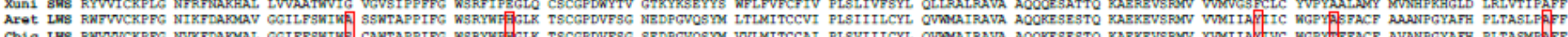

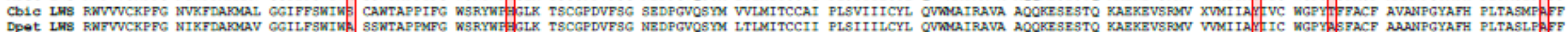

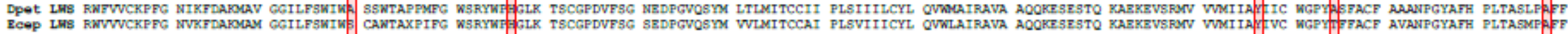

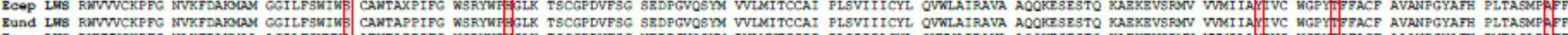

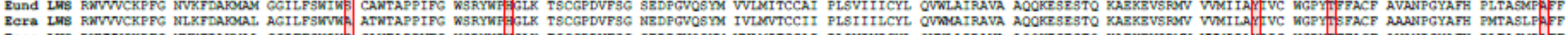

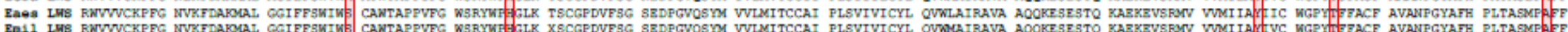

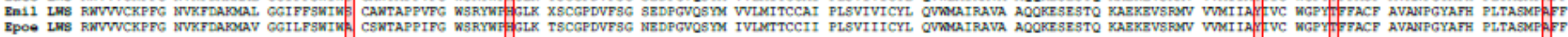

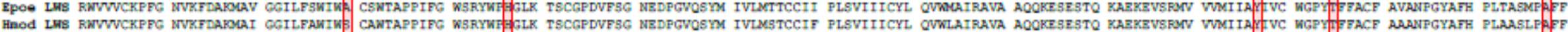

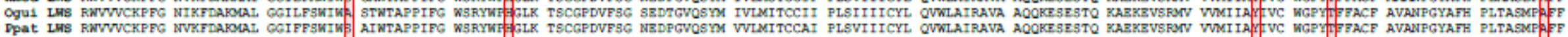

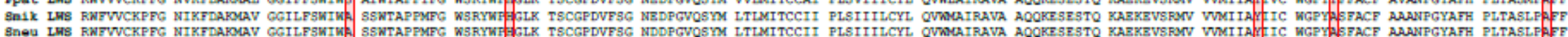

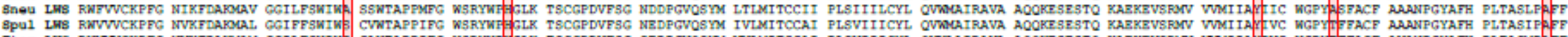

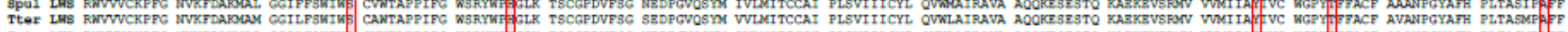

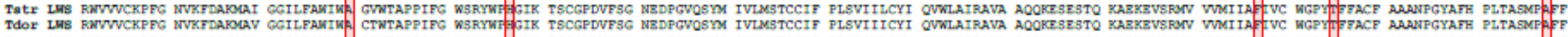

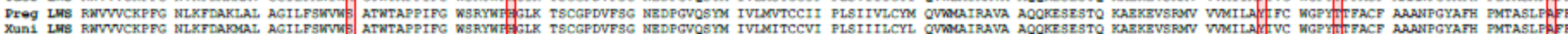




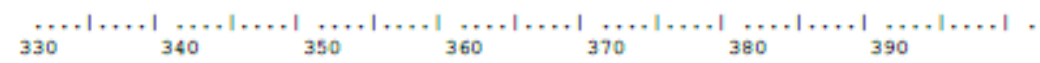

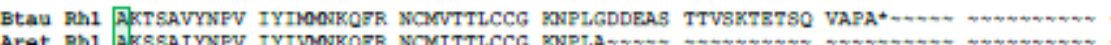

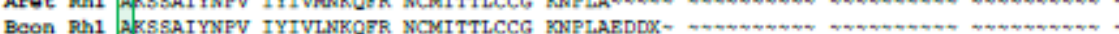

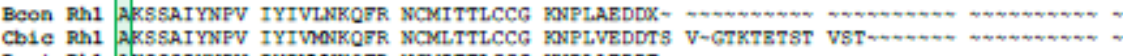

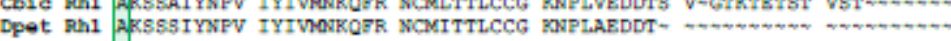

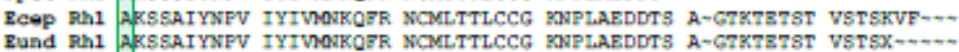

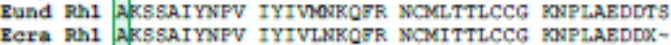

VV IYTMOTKOFR NCMLTTLCCG RNPLARXX-

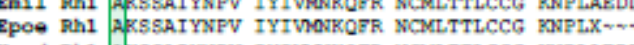

Thut

Dett Dh

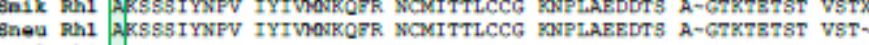

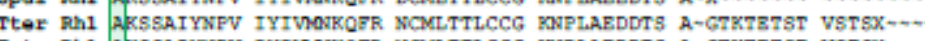

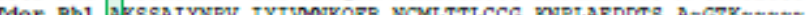

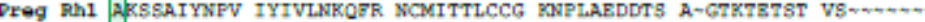

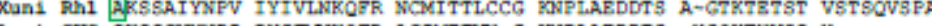

ATE

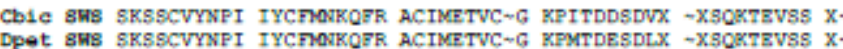

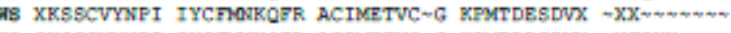

Eund 8WS SRSSCVYSPI TYC NOSKOFR ACTMETVC $\sim G$ KPMTDDSDVX -XF3

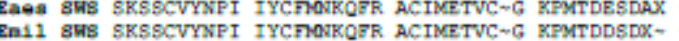

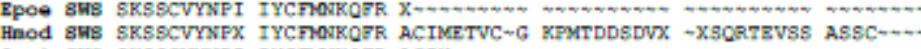

OGUI BHS SKSSCVYSPI IYCANONKGFR ACIR-T.

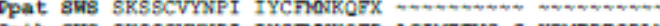

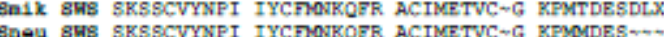

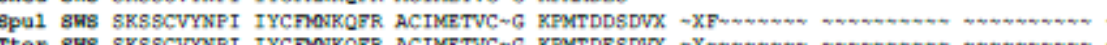

Tatr BHS SKSSCVYSPI IYCANORKOFR ACTMETVC $-G$ KPYTDDDSDVX

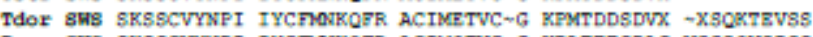

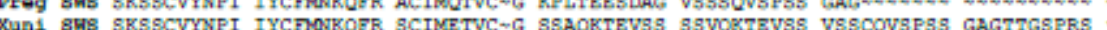

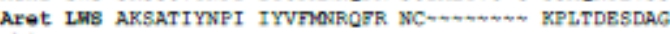

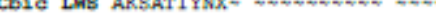

Ecop LUS AKSATTYSPI IYVROAROFR

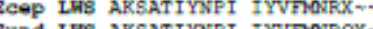

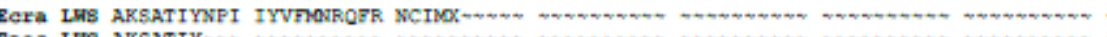

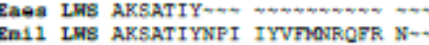

Epoe LMS ARSATIYSPT

Haod LYS ARSATTYMPI TYVANC-

gnik LHS ARSATTYSPI IYVPY

SneU LHS ARSATIYSF

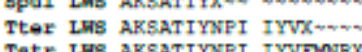

Tdor LHS ARSATIYSPI IYVADORROFR NCIND -

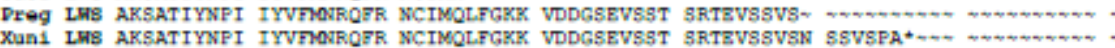

Btau, Bos taurus; Aret, Atractus reticulatus; Bcon, Boa constrictor; Cbic, Chironius bicarinatus; Dpet, Dipsas petersi; Ecep, Echinantera cephalostriata; Eund, Echinantera undulata; Ecra, Epicrates crassus; Eaes, Erythrolamprus aesculapii; Emil, Erythrolamprus miliaris; Epoe, Erythrolamprus poecilogyrus; Hmod, Helicops modestus; Oguib, Oxyrhopus guibei; Ppat, Philodryas patagoniensis; Smik, Sibynomorphus mikanii; Sneu, Sibynomorphus neuwiedi; Spul, Spilotes pullatus; Tter, Taeniophallus persimilis; Tstr, Thamnodynates hypoconia; Tdor, Tomodon dorsatus; Preg, Python regius; Xun, Xenopeltis unicolor. 


\section{Anexo 7.}

Parâmetros estereológicos utilizados para amostragem de células da camada de células ganglionares (CCG), de retinas de serpentes Dipsadidae e Colubridae.

\begin{tabular}{|c|c|c|c|c|c|c|}
\hline Espécie & $\begin{array}{c}\text { Quadro de } \\
\text { Amostragem } \\
(\mu \mathrm{m})\end{array}$ & $\begin{array}{l}\text { Grade } \\
(\mu \mathrm{m})\end{array}$ & asf & Objetiva/AN & $\begin{array}{c}\text { Área da } \\
\text { retina }(\mathrm{mm})\end{array}$ & $\begin{array}{l}\text { N. campos } \\
\text { amostrados }\end{array}$ \\
\hline A. pantostictus & $74 \times 74$ & $200 \times 200$ & 0,36 & $100 x / 1.25$ oil & 2,7 & 93 \\
\hline \multirow{2}{*}{ A. reticulatus } & $184 \times 184$ & $310 \times 310$ & 0,13 & $40 x / 0.7$ oil & 3,8 & 29 \\
\hline & $74 \times 74$ & $120 \times 120$ & 0,36 & $100 x / 1.25$ oil & 2,4 & 158 \\
\hline \multirow{2}{*}{ C. bicarinatus } & $184 \times 184$ & $950 \times 950$ & 0,036 & 40x/0.7 oil & 58,6 & 62 \\
\hline & $74 \times 74$ & $950 \times 950$ & 0,018 & $100 x / 1.25$ oil & 62 & 208 \\
\hline D. albifrons & $184 \times 184$ & $580 \times 580$ & 0,1 & 40x/0.7 oil & 18,3 & 54 \\
\hline D. petersi & $74 \times 74$ & $440 \times 440$ & 0,03 & $100 x / 1.25$ oil & 28,2 & 148 \\
\hline \multirow{2}{*}{ E. undulata } & $184 \times 184$ & $720 \times 720$ & 0,06 & 40x/0.7 oil & 25,4 & 49 \\
\hline & $184 \times 184$ & $670 \times 670$ & 0,07 & $40 x / 0.7$ oil & 24,6 & 54 \\
\hline \multirow{2}{*}{ E. aesculapii } & $192 \times 192$ & $640 \times 640$ & 0,09 & $40 x / 0.7$ oil & 17,5 & 43 \\
\hline & $184 \times 184$ & $680 \times 680$ & 0,07 & $40 x / 0.7$ oil & 33 & 72 \\
\hline \multirow{3}{*}{ E. miliaris } & $194 \times 194$ & $550 \times 550$ & 0,12 & 40x/0.7 oil & 19,2 & 63 \\
\hline & $184 \times 184$ & $750 \times 750$ & 0,06 & 40x/0.7 oil & 17,8 & 32 \\
\hline & $74 \times 74$ & $320 \times 320$ & 0,05 & $100 x / 1.25$ oil & 22 & 217 \\
\hline \multirow{2}{*}{ E. poecilogyrus } & $184 \times 184$ & $600 \times 600$ & 0,09 & $40 x / 0.7$ oil & 17,9 & 49 \\
\hline & $74 \times 74$ & $320 \times 320$ & 0,05 & $100 x / 1.25$ oil & 15,7 & 155 \\
\hline \multirow{3}{*}{ H. modestus } & $184 \times 184$ & $460 \times 460$ & 0,16 & 40x/0.7 oil & 8,2 & 39 \\
\hline & $184 \times 184$ & $580 \times 580$ & 0,1 & $40 x / 0.7$ oil & 13,9 & 41 \\
\hline & $184 \times 184$ & $450 \times 450$ & 0,17 & $40 x / 0.7$ oil & 7,4 & 36 \\
\hline \multirow{3}{*}{ O. guibei } & $192 \times 192$ & $530 \times 530$ & 0,13 & $40 x / 0.7$ oil & 9 & 32 \\
\hline & $192 \times 192$ & $520 \times 520$ & 0,14 & 40x/0.7 oil & 7,6 & 28 \\
\hline & $192 \times 192$ & $500 \times 500$ & 0,14 & $40 x / 0.7$ oil & 11,2 & 45 \\
\hline \multirow{3}{*}{ S. mikanii } & $192 \times 192$ & $600 \times 600$ & 0,1 & 40x/0.7 oil & 7,5 & 21 \\
\hline & $192 \times 192$ & $510 \times 510$ & 0,14 & 40x/0.7 oil & 6,5 & 25 \\
\hline & $192 \times 192$ & $450 \times 450$ & 0,18 & 40x/0.7 oil & 8,0 & 39 \\
\hline \multirow{2}{*}{ S. neuwiedii } & $184 \times 184$ & $600 \times 600$ & 0,1 & $40 x / 0.7$ oil & 16,6 & 47 \\
\hline & $74 \times 74$ & $220 \times 220$ & 0,11 & $100 x / 1.25$ oil & 12,9 & 272 \\
\hline \multirow{2}{*}{ S. pullatus } & $74 \times 74$ & $520 \times 520$ & 0,02 & $100 x / 1.25$ oil & 86,4 & 316 \\
\hline & $74 \times 74$ & $680 \times 680$ & 0,01 & $100 x / 1.25$ oil & 87,5 & 190 \\
\hline \multirow{3}{*}{ T. dorsatus } & $192 \times 192$ & $550 \times 550$ & 0,12 & 40x/0.7 oil & 19,2 & 62 \\
\hline & $184 \times 184$ & $600 \times 600$ & 0,09 & 40x/0.7 oil & 20 & 55 \\
\hline & $184 \times 184$ & $530 \times 530$ & 0,12 & $40 x / 0.7$ oil & 19 & 67 \\
\hline \multirow{3}{*}{ T. strigatus } & $184 \times 184$ & $540 \times 540$ & 0,11 & 40x/0.7 oil & 11 & 39 \\
\hline & $184 \times 184$ & $600 \times 600$ & 0,08 & $40 x / 0.7$ oil & 29,3 & 67 \\
\hline & $184 \times 184$ & $690 \times 690$ & 0,07 & 40x/0.7 oil & 17,7 & 37 \\
\hline
\end{tabular}

asf, area of sampling fraction (área da fração de amostragem); AN, abertura numérica. 


\section{Anexo 8.}

Parâmetros estereológicos utilizados para amostragem de fotorreceptores, de retinas de serpentes Dipsadidae e Colubridae.

\begin{tabular}{|c|c|c|c|c|c|c|}
\hline Espécie & $\begin{array}{c}\text { Quadro de } \\
\text { Amostragem } \\
(\mu \mathrm{m})\end{array}$ & Grade $(\mu \mathrm{m})$ & asf & Objetiva/AN & $\begin{array}{c}\text { Área da } \\
\text { retina }(\mathrm{mm})\end{array}$ & $\begin{array}{l}\text { N. campos } \\
\text { amostrados }\end{array}$ \\
\hline \multirow{2}{*}{ A. pantostictus } & $74 \times 74$ & $140 \times 140$ & 0,3 & $100 x / 1.25$ oil & 2,9 & 155 \\
\hline & $74 \times 74$ & $290 \times 290$ & 0,07 & 40x/0.7 oil & 3,8 & 46 \\
\hline \multirow{3}{*}{ A. reticulatus } & $192 \times 1924$ & $350 \times 350$ & 0,3 & $100 \mathrm{x} / 1.25$ oil & 2,9 & 24 \\
\hline & $74 \times 74$ & $120 \times 120$ & 0,4 & $100 x / 1.25$ oil & 3 & 216 \\
\hline & $74 \times 74$ & $130 \times 130$ & 0,3 & $100 x / 1.25$ oil & 3 & 170 \\
\hline \multirow{7}{*}{ C. bicarinatus } & $192 \times 192$ & $1000 \times 1000$ & 0,04 & $40 x / 0.7$ oil & 56 & 53 \\
\hline & $184 \times 184$ & $950 \times 950$ & 0,04 & 40x/0.7 oil & 66 & 74 \\
\hline & $184 \times 184$ & $1200 \times 1200$ & 0,02 & 40x/0.7 oil & 120 & 81 \\
\hline & $184 \times 184$ & $890 \times 890$ & 0,04 & 40x/0.7 oil & 60 & 75 \\
\hline & $184 \times 184$ & $1300 \times 1300$ & 0,03 & 40x/0.7 oil & 59 & 46 \\
\hline & $184 \times 184$ & $940 \times 940$ & 0,04 & 40x/0.7 oil & 80 & 91 \\
\hline & $74 \times 74$ & $440 \times 440$ & 0,03 & $100 x / 1.25$ oil & 55 & 290 \\
\hline \multirow{4}{*}{ D. bucephala } & $58 \times 58$ & $460 \times 460$ & 0,02 & $100 x / 1.25$ oil & 35 & 166 \\
\hline & $39 \times 39$ & $330 \times 330$ & 0,01 & $100 x / 1.25$ oil & 33 & 297 \\
\hline & $39 \times 39$ & $360 \times 360$ & 0,01 & $100 x / 1.25$ oil & 39 & 299 \\
\hline & $74 \times 74$ & $340 \times 340$ & 0,01 & $100 \mathrm{x} / 1.25$ oil & 28 & 248 \\
\hline D. petersi & $32 \times 32$ & $900 \times 900$ & 0,007 & $100 \mathrm{x} / 1.25$ oil & 28 & 37 \\
\hline \multirow{3}{*}{ E. undulata } & $194 \times 194$ & $600 \times 600$ & 0,1 & 40x/0.7 oil & 23 & 63 \\
\hline & $184 \times 184$ & $720 \times 720$ & 0,07 & 40x/0.7 oil & 25 & 49 \\
\hline & $184 \times 184$ & $680 \times 680$ & 0,07 & 40x/0.7 oil & 25 & 53 \\
\hline \multirow{6}{*}{ E. aesculapii } & $192 \times 192$ & $650 \times 650$ & 0,09 & 40x/0.7 oil & 19 & 45 \\
\hline & $184 \times 184$ & $680 \times 680$ & 0,07 & 40x/0.7 oil & 33 & 72 \\
\hline & $184 \times 184$ & $700 \times 700$ & 0,07 & 40x/0.7 oil & 28 & 56 \\
\hline & $184 \times 184$ & $560 \times 560$ & 0,11 & 40x/0.7 oil & 32 & 103 \\
\hline & $184 \times 184$ & $680 \times 680$ & 0,07 & 40x/0.7 oil & 36 & 77 \\
\hline & $74 \times 74$ & $360 \times 360$ & 0,04 & $100 x / 1.25$ oil & 34 & 271 \\
\hline \multirow{5}{*}{ E. miliaris } & $184 \times 184$ & $700 \times 700$ & 0,07 & $40 x / 0.7$ oil & 25 & 51 \\
\hline & $184 \times 184$ & $800 \times 800$ & 0,05 & 40x/0.7 oil & 18 & 28 \\
\hline & $74 \times 74$ & $320 \times 320$ & 0,05 & $100 \mathrm{x} / 1.25$ oil & 22 & 213 \\
\hline & $74 \times 74$ & $360 \times 360$ & 0,04 & $100 x / 1.25$ oil & 26 & 201 \\
\hline & $74 \times 74$ & $400 \times 400$ & $0,-3$ & $100 x / 1.25$ oil & 36 & 230 \\
\hline \multirow{7}{*}{ E. poecilogyrus } & $194 \times 194$ & $610 \times 600$ & 0,1 & $40 x / 0.7$ oil & 21 & 56 \\
\hline & $184 \times 184$ & $990 \times 320$ & 0,03 & 40x/0.7 oil & 21 & 21 \\
\hline & $184 \times 184$ & $600 \times 600$ & 0,09 & 40x/0.7 oil & 18 & 49 \\
\hline & $184 \times 184$ & $670 \times 670$ & 0,07 & 40x/0.7 oil & 27 & 59 \\
\hline & $74 \times 74$ & $400 \times 400$ & 0,03 & $100 x / 1.25$ oil & 25 & 154 \\
\hline & $74 \times 74$ & $330 \times 330$ & 0,01 & $100 x / 1.25$ oil & 27 & 249 \\
\hline & $74 \times 74$ & $340 \times 340$ & 0,05 & $100 x / 1.25$ oil & 16 & 137 \\
\hline \multirow{8}{*}{ H. modestus } & $184 \times 184$ & $570 \times 460$ & 0,1 & $40 x / 0.7$ oil & 10,8 & 33 \\
\hline & $184 \times 184$ & $630 \times 580$ & 0,09 & 40x/0.7 oil & 8,2 & 21 \\
\hline & $184 \times 184$ & $610 \times 450$ & 0,09 & 40x/0.7 oil & 13,9 & 41 \\
\hline & $184 \times 184$ & $510 \times 510$ & 0,13 & 40x/0.7 oil & 10 & 39 \\
\hline & $184 \times 184$ & $460 \times 460$ & 0,16 & 40x/0.7 oil & 7,4 & 34 \\
\hline & $74 \times 74$ & $230 \times 230$ & 0,1 & $100 x / 1.25$ oil & 11,2 & 211 \\
\hline & $74 \times 74$ & $210 \times 210$ & 0,12 & $100 x / 1.25$ oil & 9,1 & 203 \\
\hline & $74 \times 74$ & $220 \times 220$ & 0,11 & $100 x / 1.25$ oil & 11,2 & 229 \\
\hline
\end{tabular}

asf, area of sampling fraction (área da fração de amostragem); AN, abertura numérica. 